


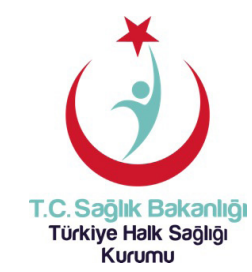

T.C.

SAĞLIK BAKANLIĞI

TÜRKIYE HALK SAĞLIĞI KURUMU

T.R.

THE MINISTRY OF HEALTH

PUBLIC HEALTH INSTITUTION OF TURKEY

ISSN 0377-9777 (Basılı / Printed)

ISSN 1308-2523 (Çevrimiçi / Online)

\section{TÜRK HIJJYEN}

\section{ve \\ DENEYSEL BIYOLOJi DERGISI}

Turk Hij Den Biyol Derg

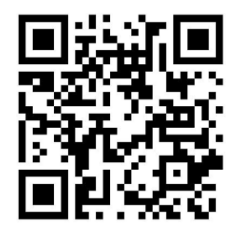




\section{TÜRK HIJYEN ve DENEYSEL BIYOLOJI DERGISI}

TURKISH BULLETIN OF HYGIENE AND EXPERIMENTAL BIOLOGY

Sahibi / Owner

Türkiye Halk Sağlığı Kurumu adına

On behalf of Public Health Institution of Turkey

İrfan ŞENCAN, Bașkan (President)

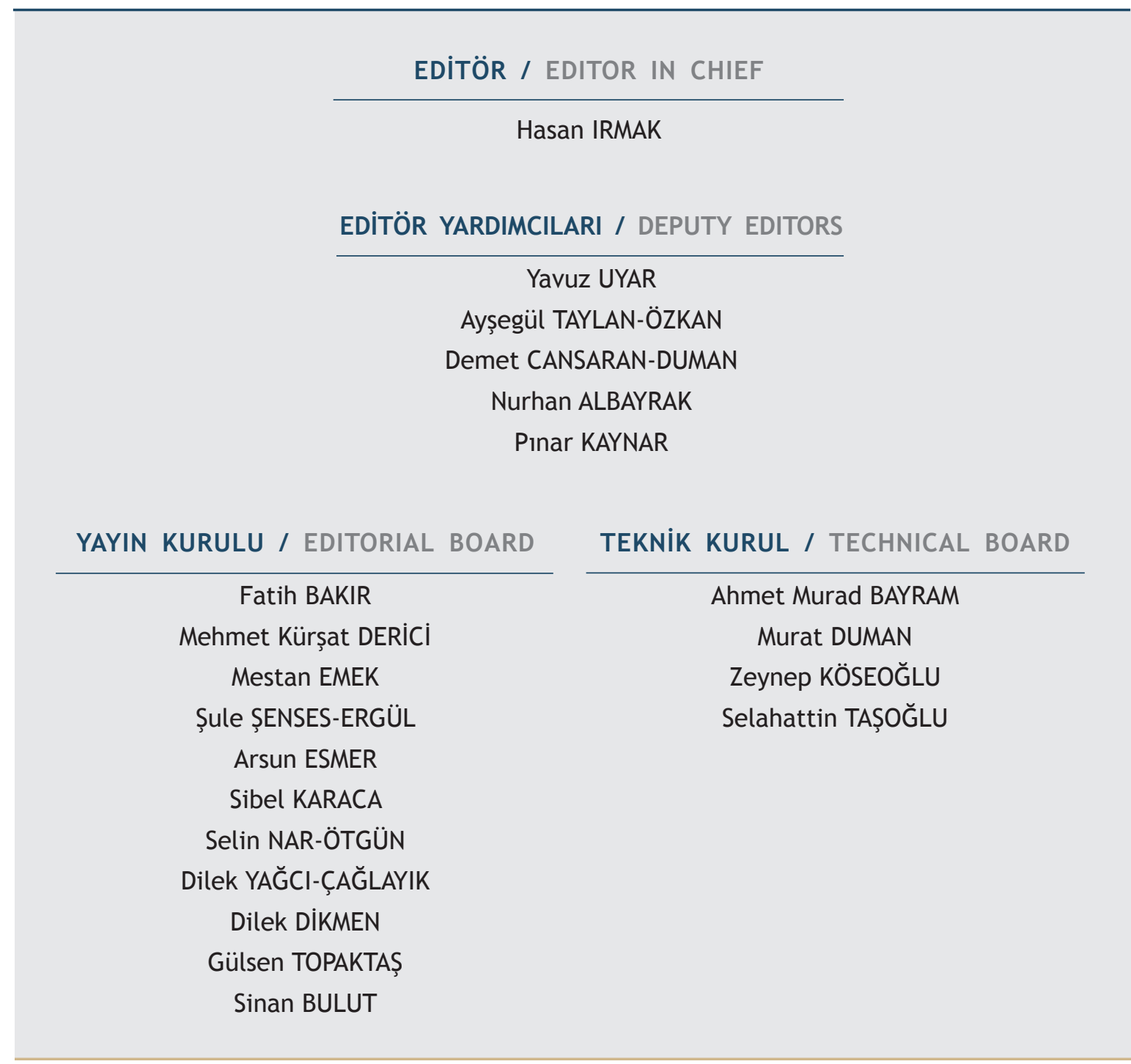

TÜRKIYE HALK SAĞLIĞI KURUMU

PUBLIC HEALTH INSTITUTION OF TURKEY

ANKARA-TÜRKIYE

Yılda dört kez yayımlanır / Published four times per year

Asitsiz kağıt kullanılmıştır / Acid free paper is used

Tasarım - Dizgi / Design - Editing :

Türkiye Halk Sağığı Kurumu / Public Health Institution of Turkey

Destek Hizmetleri / Supportive Services

Satınalma ve İdari İşler Daire Başkanlığı /

Purchasing and Administrative Affairs Department
Baskı ve Cilt / Press and Binding :

Azim Matbaacılık

Büyük Sanayi 1. Cad. No: 99/33 iskitler-ANKARA

Tel: +90 31234203 71-72

e-posta: info@azimmatbaacilik.com
Yayın Türü / Type of Publication : Yerel Süreli Yayın / Periodical Publication

Basım Tarihi / Date of Publication : 2016 


\section{TÜRK HIJYEN ve DENEYSEL BIYOLOJI DERGISI \\ TURKISH BULLETIN OF HYGIENE AND EXPERIMENTAL BIOLOGY}

\section{ULUSLARARASI BILIMSEL DANIŞMA KURULU / INTERNATIONAL SCIENTIFIC ADVISORY BOARD}

Ali MIRAZIMI, Sweden

Anna PAPA, Greece

Aziz SANCAR, USA

Cristina DOMINGO, Germany

Daniel MOTLHANKA, Botswana

Dwight D. BOWMAN， USA

Isme HUMOLLI, Kosovo

Isuf DEDUSHAJ, Kosovo

Iva CHRISTOVA, Bulgaria

Johan LINDH, Sweden
Kosta Y. MUMCUOĞLU, Israel

Manfred WEIDMANN, U.Kingdom

Paul HEYMAN, Belgium

Pauline MWINZI, Kenya

Roberto Caneta VILLAFRANCE， Cuba

Sıraç DILBER, Sweden

Susana RODRIGUEZ-COUTO, Spain

Takashi AKAMATSU, Japan

Varalakshmi ELANGO, India

\section{ULUSAL BILIMSEL DANIŞMA KURULU / NATIONAL SCIENTIFIC ADVISORY BOARD}

\section{A. Gülçin SAĞDIÇOĞLU-ÇELEP, Ankara}

Ahmet ÇARHAN, Ankara

Ahmet KART, Ankara

Akçahan GEPDİREMEN, Bolu

Ali ALBAY, Ankara

Ali Kudret ADİLOĞLU, Ankara

Ali Naci YILDIZ, Ankara

Alp ERGÖR, İzmir

Alper AKÇALI, Çanakkale

Arsun ESMER, Ankara

Aşkın YAŞAR, Ankara

Ateş KARA, Ankara

Aydan ÖZKÜTÜK, İzmir

Ayhan FILAZI, Ankara

Aykut ÖZKUL, Ankara

Ayşegül TAYLAN ÖZKAN, Çorum

Banu ÇAKIR, Ankara

Bayram ŞAHIN, Ankara

Bekir ÇELEBİ, Ankara

Belgin ÜNAL, İzmir

Berrin ESEN, Ankara

Birce TABAN, Ankara

Bülent ALTEN, Ankara

Celal F. GÖKÇAY, Ankara
Cemal SAYDAM, Ankara

Çağatay GÜLER, Ankara

Delia Teresa SPONZA, İzmir

Demet CANSARAN DUMAN, Ankara

Dilek ASLAN, Ankara

Dilek DIKMEN, Ankara

Dilek YAĞCI ÇAĞLAYIK, İstanbul

Diler ASLAN, Denizli

Doğan YÜCEL, Ankara

Duygu ÖZEL DEMIRALP, Ankara

Duygu TUNCER, Ankara

Ender YARSAN, Ankara

Erhan ESER, Manisa

Erkan YILMAZ, Ankara

Fatih BAKIR, Ankara

Fatih KÖKSAL, Adana

Fügen DURLU ÖZKAYA, Ankara

Fügen YÖRÜK, Ankara

Gönül ŞAHIIN, Ankara

Görkem MERGEN, Ankara

Gül ERGÖR, İzmir

Gül Ruhsar YILMAZ, Ankara

Gülberk UÇAR, Ankara

Gülnur TARHAN, Adıyaman 


\section{TÜRK HIJYEN ve DENEYSEL BIYOLOJI DERGISI}

\section{TURKISH BULLETIN OF HYGIENE AND EXPERIMENTAL BIOLOGY}

ULUSAL BİLIMSEL DANIŞMA KURULU / NATIONAL SCIENTIFIC ADVISORY BOARD

\begin{tabular}{|c|c|}
\hline Hakan ABACIOĞLU, İzmir & Ömer Faruk TEKBAŞ, Ankara \\
\hline Hakan LEBLEBİCiOĞLU, Samsun & Özlem KURT AZAP, Ankara \\
\hline Haluk VAHABOĞLU, İstanbul & Pinar KAYNAR, Ankara \\
\hline Hasan IRMAK, Ankara & Pınar OKYAY, Aydın \\
\hline Hasan TEZER, Ankara & Rahmet GÜNER, Ankara \\
\hline Hilal ÖZDAĞ, Ankara & Recep AKDUR, Ankara \\
\hline Hürrem BODUR, Ankara & Recep KEŞLI, Afyon \\
\hline Işıl MARAL, İstanbul & Recep ÖZTÜRK, İstanbul \\
\hline İ. Mehmet Ali OKTEM, İzmir & Rıza DURMAZ, Ankara \\
\hline $\begin{array}{l}\text { Irran EKUL, Ankara } \\
\text { İrfan SEENCAN, Ankara }\end{array}$ & S. Aykut AYTAÇ, Ankara \\
\hline İsmail CEYHAN, Ankara & Sami AYDOĞAN, Kayseri \\
\hline Kemal Osman MEMIKOĞLU, Ankara & Sarp ÜNER, Ankara \\
\hline Koray ERGÜNAY, Ankara & Seçil ÖZKAN, Ankara \\
\hline Levent AKIN, Ankara & Seda KARASU YALÇIN， Bolu \\
\hline Mahinur AKKAYA, Ankara & Seda TEZCAN, Mersin \\
\hline Mehmet Ali ONUR, Ankara & Selçuk KAYA, Trabzon \\
\hline Mehmet Kürşat DERICİ, Çorum & Selçuk KILIÇ, Ankara \\
\hline Mestan EMEK, İzmir & Selim KILIÇ, Ankara \\
\hline Metin KORKMAZ, İzmir & Selin NAR ÖTGÜN, Ankara \\
\hline Mithat ŞAHIIN, Kars & Sema BURGAZ, Ankara \\
\hline Muhsin AKBABA, Adana & Sercan ULUSOY, İzmir \\
\hline Murat DiZBAY, Ankara & Sibel KARACA, Ankara \\
\hline Murat GÜNAYDIN, İstanbul & Sultan ESER, İzmir \\
\hline Murat HÖKELEK, İstanbul & Suzan ÖZTÜRK YILMAZ, Sakarya \\
\hline Mustafa Kemal BAŞARALI, Ankara & Süheyla SÜRÜCÜOĞLU, Manisa \\
\hline Mustafa KAVUTÇU, Ankara & Sümer ARAS, Ankara \\
\hline Mutlu ÇELIK, Kocaeli & Şule SENSES ERGÜL, Ankara \\
\hline $\begin{array}{l}\text { Mükerrem KAYA, Erzurum } \\
\text { Nazmi ÖZER. Ankara }\end{array}$ & Tevfik PINAR, Kırıkkale \\
\hline Nilay ÇÖPLÜ, Ankara & Yavuz UYAR, İstanbul \\
\hline Nur AKSAKAL, Ankara & Yeşim ÇETINKAYA ŞARDAN, Ankara \\
\hline Nur Münevver PINAR, Ankara & Yeşim ÖZBAŞ, Ankara \\
\hline Nuran ESEN, İzmir & Yeşim TUNÇOK, İzmir \\
\hline Nurhan ALBAYRAK, Ankara & Zafer ECEVIT, Ankara \\
\hline Nuri KİRAZ, İstanbul & Zafer KARAER, Ankara \\
\hline Oğuz GÜRSOY, Denizli & Zati VATANSEVER, Kars \\
\hline Orhan BAYLAN, İstanbul & Zehranur YÜKSEKDAĞ, Ankara \\
\hline Orhan YILMAZ, Ankara & Zeynep GÜLAY, İzmir \\
\hline
\end{tabular}




\section{TÜRK HIJYEN VE DENEYSEL BIYOLOJI DERGISI YAZIM KURALLARI}

Dergide yayımlanmak üzere gönderilen yazılar, Türk Hijyen ve Deneysel Biyoloji Dergisi yazım kurallarına göre hazırlanmalıdır. Bașvurular www.turkhijyen.org adresinden "Çevrimiçi Makale Gönder, Takip Et, Değerlendir Programı" aracılığıyla on line olarak yapılabilir.

Gönderilen yazılarda aşağıdaki kurallara uyum aranır. Kurallara uymayan yazılar daha ileri bir incelemeye gerek görülmeksizin yazarlarına iade edilir.

1. "Telif Hakkı Devir Formu" tüm yazarlarca imzalanarak onaylandıktan sonra dergimizin makale kabul sistemine yüklenmelidir.

2. Makale bașlı̆̆ı İngilizce bașlık, kısa bașlık, yazar adları, çalıșılan kurumlara ait birimler, yazıșma ișini üstlenen yazarın açık adresi, telefon numaraları (sabit ve cep), elektronik posta adresi belirtilmelidir:

a. Yazının bașlığı kısa olmalı ve küçük harfle yazılmalıdır.

b. Sayfa bașlarına konan kısa bașlık 40 karakteri geçmemelidir.

c. Çalışma bilimsel bir kuruluș ve/veya fon ile desteklenmişse dipnot veya teșekkür bölümünde mutlaka belirtilmelidir.

d. Makale, kongre/sempozyumda sunulmușsa sunum türü ile birlikte dipnot veya teșekkür bölümünde mutlaka belirtilmelidir.

3. Yazılardaki terimler mümkün olduğunca Türkçe ve Latince olmalı, dilimize yerleșmiș kelimelere yer verilmeli ve Türk Dil Kurumu'nun güncel sözlüğü kullanıımalıdır. Öz Türkçe’ye özen gösterilmeli ve Türkçe kaynak kullanımına önem verilmelidir.

4. Metin içinde geçen mikroorganizma isimleri ilk kullanıldığında tam ve açı yazılmalı, daha sonraki kullanımlarda kısaltılarak verilmelidir. Mikroorganizmaların orijinal Latince isimleri italik yazılmalıdır: Örneğin; Pseudomonas aeruginosa, P. aeruginosa gibi. Yazıda sadece cins adı gecen cümlelerde stafilokok, streptokok gibi dilimize yerlesmis cins adları Türkce olarak yazılabilir. Antibiyotik isimleri dil bütünlüğü açısından okunduğu gibi yazılmalı; uluslararası standardlara uygun olarak kısaltılmalıdır.

5. Metin içerisinde bahsedilen birimlerin sembolleri Uluslararası Birimler Sistemi (SI)'ne göre verilmelidir.

6. Yazılar bir zorunluluk olmadıkça "geçmiș zaman edilgen" kip ile yazıımalıdır. 7. Metnin tamamı 12 punto Times New Roman karakteri ile çift aralıkla yazılmalı ve sayfa kenarlarından $2,5 \mathrm{~cm}$ boșluk bırakılmalıdır.

8. Yazarlar araștırma ve yayın etiğine uymalıdır. Klinik araștırmalarda, çalıșmaya katılanlardan bilgilendirilmis olur alındı̆̆ının gerec ve yöntem bölümünde belirtilmesi gerekmektedir. Gönüllü ya da hastalara uygulanacak prosedürlerin özelliği tümüyle anlatıldıktan sonra, kendilerinin bilgilendirilip onaylarının alındığını gösterir bir cümle bulunmalıdır. Yazarlar Helsinki Bildirgesi'nde ana hatları çizilen ilkeleri izlemelidir. Yazarlar, bu tür bir çalıșma söz konusu olduğunda, uluslararası alanda kabul edilen kılavuzlara ve yürürlükte olan tüm mevzuatta belirtilen hükümlere uymalı ve "Etik Kurul Onayı”nı göndermelidir.

9. Hayvanlar üzerinde yapılan çalıșmalar için de gereken izinler alınmalı; yazıda deneklere ağrı, acı ve rahatsızlık verilmemesi için neler yapıldığı açık bir șekilde belirtilmelidir.

10. Hasta kimliğini tanıtacak fotoğraf kullanıldığında, hastanın yazılı onayı gönderilmelidir.

11. Araștırma yazıları;

Türkçe Özet, İngilizce Özet, Giris, Gerec ve Yöntem, Bulgular, Tartısma, Teșekkür (varsa) ve Kaynaklar bölümlerinden olușmalıdır. Bu bölüm bașlıkları sola yaslanacak șekilde büyük harflerle kalın yazılmalıdır. İngilizce makalelerde de Türkçe bașlık, kısa bașlık ve özet bulunmalıdır.

a) Türkçe Özet: Amaç, Yöntem, Bulgular ve Sonuç, alt bașlıklarından olușmalıdır (yapılandırılmıș özet) ve en az 250, en fazla 400 kelime içermelidir.

b) İngilizce Özet (Abstract): Türkçe Özet bölümünde belirtilenleri birebir karșılayacak șekilde "Objective, Method, Results, Conclusion" olarak yapilandırılmalidır.

c) Anahtar Kelimeler: 3-8 arasında olmalı ve Index Medicus Medical Subject Headings-(MeSH)'de yer alan kelimeler kullanılmalıdır. Türkce anahtar kelimelerinizi olușturmak için http://www.bilimterimleri.com/ adresini kullanınız.

d) Giriș: Araștırmanın amacı ve gerekçesi güncel literatür bilgisi ile desteklenerek iki sayfayı așmayacak șekilde sunulmalıdır.

e) Gereç ve Yöntem: Araștırmanın gerçekleștirildiği kurum/kuruluş ve tarih belirtilmeli, araștırmada kullanılan araç, gereç ve yöntem sunulmalı; istatistiksel yöntemler açıkça belirtilmelidir.

f) Bulgular: Sadece araștırmada elde edilen bulgular belirtilmelidir

g) Tartışma: Araștırmanın sonunda elde edilen bulgular, diğer araștıııcıların bulgularıyla karșılaștırılmalıdır. Araștırıcı, kendi yorumlarını bu bölümde aktarmalıdır. h) Teşekkür: Ana metnin sonunda kaynaklardan hemen önce yer almalıdır. Teșekkür bölümünde çalıșmaya destek veren kiși, kurum/kurulușlar yer almalıdır.

i) Kaynaklar: Yazarlar kaynakların eksiksiz ve doğru yazılmasından sorumludur. Kaynaklar, metnin içinde geçiş sırasına göre numaralandırılmalıdır. Numaralar, parantez içinde cümle sonlarında verilmelidir. Kaynakların yazılımı ile ilgili assağılda örnekler verilmistir. Daha detaylı bilgi icin "Uniform Requirements for Manuscripts submitted to Biomedical Journals" (J Am Med Assoc 1997; 277: 927-934) (http://www.nejm.org/) bakılmalıdır.

Süreli yayın: Yazar(lar)ın Soyadı Adının baș harf(ler)i (altı veya daha az yazar varsa hepsi yazılmalıdır; yazar sayısı yedi veya daha çoksa yalnız ilk altısın yazıp "et al." veya "ve ark." eklenmelidir). Makalenin bașlığı, Derginin Index Medicus'a uygun kısaltılmıș ismi, Yıl; Cilt (Sayı): lilk ve son sayfa numarası.

- Standard dergi makalesi için örnek: Demirci M, Ünlü M, Şahin Ü. A case of hydatid lung cyst diagnosed by kinyoun staining of bronco-alveolar fluid. Turkiye Parazitol Derg, 2001; 25 (3): 234-5.

- Yazarı verilmemiș makale için örnek: Anonymous. Coffee drinking and cancer of the panceras (Editorial). Br Med J, 1981; 283: 628.

- Dergi eki için örnek: Frumin AM, Nussbaum J, Esposito M. Functinal asplenia: Demonstration of splenic activity by bone marrow scan (Abstract). Blood, 1979; 54 (Suppl 1): 26 a.

Kitap: Yazar(lar)ın soyadı adının baș harf(ler)i. Kitabın adı. Kaçıncı baskı olduğu. Basım yeri: Yayınevi, Basım yıı.ı.

- Örnek: Eisen HN. Immunology: an Introduction to Molecular and Cellular Principles of the Immun Response. 5th ed. New York: Harper and Row, 1974.

Kitap bölümü: Bölüm yazar(lar)ın soyadı adının bashharf(ler)i. Bölüm basslığı. In: Editör(ler)in soyadı adının bașharf(ler)i ed/eds. Kitabın adı. Kaçıncı bask olduğu. Basım yeri: Yayınevi, Basım yılı: Bölümün ilk ve son sayfa numarası.

- Örnek: Weinstein L. Swarts MN. Pathogenic properties of invading microorganisms. In: Sodeman WA Jr, Sodeman WA, eds. Pathologic Physio ogy: Mechanism of Disease. Phidelphia. WB Saunders, 1974: 457-72.

Web adresi: Eğer doğrudan "web" adresi referans olarak kullanılacaksa adres ile birlikte parantez iccinde bilgiye ulașılan tarih de belirtilmelidir. Web erisiml makalelerin referans olarak metin içinde verilmesi gerektiğinde DOI (Digital Object Identifier) numarası verilmesi șarttır.

Kongre bildirisi: Entrala E, Mascaro C. New stuructural findings in Cryptosporidium parvum oocysts. Eighth International Congress of Parasitology (ICOPA VIII). October,10-14, Izmir-Turkey. 1994.

Tez: Bilhan Ö. Labirent savakların hidrolik karakteristiklerinin deneysel olarak incelenmesi. Yüksek Lisans Tezi, Fırat Üniversitesi Fen Bilimleri Enstitüsü, 2005.

GenBank/DNA dizi analizi: Gen kalıtım numaraları ve DNA dizileri makale içinde kaynak olarak gösterilmelidir. Konuyla ilgili ayrıntılı bilgi için "National Library of Medicine" adresinde "National Center for Biotechnical Information (NCBI)" bölümüne bakınız.

Sekil ve Tablolar: Her tablo veya sekil ayrı bir sayfaya basılmalı, alt ve üst çizgiler ve gerektiğinde ara sütun çizgileri içermelidir. Tablolar, "Tablo 1." șeklinde numaralandırılmalı ve tablo bașlığı tablo üst çizgisinin üstüne yazılmalıdır. Açılayıcı bilgiye baslıkta değil dipnotta yer verilmeli, uygun simgeler $\left({ }^{*},+,++\right.$, v.b.) kullanılmalıdır. Fotoğraflar "jpeg" formatında ve en az $300 \mathrm{dpi}$ olmalıdır. Baskı kalitesinin artırııması için gerekli olduğu durumlarda fotoğrafların orijinal halleri talep edilebilir.

12. Araștırma Makalesi türü yazılar için kaynak sayısı en fazla 40 olmalıdır.

13. Derleme türü yazılarda tercihen yazar sayısı ikiden fazla olmamalıdır. Yazar(lar) daha önce bu konuda çalıșma ve yayın yapmıș olmalı; bu deneyimlerini derleme yazısında tartısmalı ve kaynak olarak göstermelidir. Derlemelerde Türkçe ve İngilizce olarak bașlık, özet (en az 250, en fazla 400 kelime içermelidir) ve anahtar kelimeler bulunmalıdır. Derleme türü yazılar için kaynak sayısı en fazla 60 olmalıdır.

14. Olgu sunumlarında metin yedi sayfayı așmamalıdır. Türkçe ve İngilizce olarak bașlık, özet ve anahtar kelimeler ayrıca giriș, olgu ve tartıșma bölümler bulunmalıdır. Olgu sunumu türü yazılar için kaynak sayısı en fazla 20 olmalıdır.

15. Editöre Mektup: Daha önce yayımlanmıș yazılara eleștiri getirmek, katkıda bulunmak ya da bilim haberi niteliği tașıyacak bilgilerin iletilmesi amacıyla yazılan yazılar, Yayın Kurulu'nun inceleme ve değerlendirmesinin ardından yayınlanır. Editöre Mektup bir sayfayı așmamalı ve kaynak sayısı en fazla 10 olmalıdır.

16. Bu kurallara uygun olmayan metinler kabul edilmez.

17. Yazarlar teslim ettikleri yazının bir kopyasını saklamalıdır. 


\section{WRITING RULES OF TURKISH BULLETIN OF HYGIENE AND EXPERIMENTAL BIOLOGY}

Articles should be prepared according to the rules of the Turkish Bulletin of Hygiene and Experimental Biology. Submissions can be made online at the address www.turkhijyen.org through the Online "Manuscript Submission, Tracking, Evaluation Program".

Manuscripts are checked according the following rules. If the rules are not adhered to, manuscripts will be returned to the author.

1. The "Copyright Transfer Form" (Copyright Release Form) after being signed by all authors should be uploaded using the article accepting system of the journal. 2. The title of article, short title, author name(s), names of institutions and the departments of the authors, full address, telephone numbers (landline and mobile) and e-mail address should be given:

a. The title should be short and written in lower case.

b. The short title should not exceed 40 characters.

c. The study supported by a fund or scientific organisation must be mentioned in a footnote or in the acknowledgements.

d. The study presented in a conference/symposium must be mentioned with the type of presentation in footnotes or in the acknowledgements.

3. For Turkish studies; Terms used in articles should be in Turkish and Latin as much as possible, according to the latest dictionary of the "Turkish Language Institution”. Importance should e given to use pure Turkish language and as many as Turkish references.

4. Latin names of microorganisms used for the first time in the text have to be written in full. If these names are used later, they should be abbreviated in accordance to international rules. The original Latin names of microorganisms should be written in Italic: for example, Pseudomonas aeruginosa, $P$. aeruginosa. Names of antibiotics should be abbreviated in accordance with international standards.

5. Symbols of the units mentioned in the text should be according to "The Système International (SI).

6. Articles should be written in one of the "past perfect, present perfect and past" tenses and in the passive mode.

7. Only one side of A4 paper should be used and should have a $2.5 \mathrm{~cm}$ margin on each side. 12 pt, Times New Roman font and double line space should be used.

8. The Turkish Bulletin of Hygiene and Experimental Biology expects the authors to comply with the ethics of research and publication. In human research, a statement of the informed consent of those who participated in the study is needed in the section of the "Materials and Methods". In case of procedures that will apply to volunteers or patients, it should be stated that the study objects have been informed and given their approval before the study started. In case the authors do not have a local ethics committee, the principles outlined in the "Declaration of Helsinki" should have been followed. Authors should declare that they have followed the internationally accepted latest guidelines, legislation and other related regulations and should sent "Approval of the Ethics Committee".

9. In case animal studies, approval also is needed; it should be stated clearly that the subjects will be prevented as much as possible from pain, suffering and inconvenience.

10. In case patient photos are used which shows his/her ID, a written informed consent of the patient on the use of the photos must be submitted.

11. Research Articles;

Research papers should consist of Turkish abstract, English abstract,

Introduction, Materials and Methods, Results, Discussion, Acknowledgements (if any), and References sections. These sections should be written in bold capital letters and aligned left. English articles should have a Turkish abstract and title in Turkish. (If the all of the authors from abroad the manuscript and abstract can be write English language).

a) Turkish Abstract should consist of the subheadings of Objective, Methods, Results and Conclusion (Structured Abstract). It should be between 250 and 400 words.

b) English Abstract: The abstract should be structured like the Turkish abstract (Objective, Methods, Results, and Conclusion). It should be between 250 and 400 words.

c) Key words The number of keywords should be between 3-8 and the terminology of the Medical Subjects Headings (Index Medicus Medical Subject Headings-MeSH) should be used.

d) Introduction: The aim of the study, and references given to similar studies should be presented briefly and should not exceed more than two pages.

e) Materials and Methods: The date of the study, institution that performed the study, and materials and methods should be clearly presented. Statistical methods should be clearly stated.

f) Results: The results should be stated clearly and only include the current research.

g) Conclusions: In this section, the study findings should be compared with the findings of other researchers. Authors should mention their comments in this section. h) Acknowledgements should be placed at the end of the main text and before the references. In this section, the institutions/departments which supported the research should be stated.

i) References: Authors are responsible for supply complete and correct references. References should be numbered according to the order used in the text.

Numbers should be given in brackets and placed at the end of the sentence. Examples are given below on the use of references. Detailed information can be found in "Uniform Requirements for Manuscripts Submitted to Biomedical Journals" (J Am Med Assoc 1997 277: 927-934) and at http://www.nejm.org/ general/text/requirements/1.htm.

Periodicals: Author(s) Last Name initial(s) name of author(s) (if there are six or fewer authors, all authors should be written; if the number of authors are seven or more, only the first six of the authors should be written and the rest as "et al"). The title of the article, the abbreviated name of the journal according to the Index Medicus, Year; Volume (Issue): The first and last page numbers.

- Example of standard journal article: Demirci M, Unlü M, Sahin U. A case of hydatid cyst diagnosed by kinyoun staining of lung bronco-alveolar fluid. Türkiye Parazitol Derg, 2001; 25 (3): 234-5.

- Example of an article with authors unknown: Anonymous. Coffee drinking and cancer of the pancreas (Editorial). Br Med J, 1981; 283:628.

- Example of journal supplement: Frumin AM, Nussbaum J, Esposito M. Functional asplenia: Demonstration of splenic activity by bone marrow scan (Abstract). Blood, 1979; 54 (Suppl 1): 26a.

Books: Surname of the author(s) initial name(s) of author(s). The name of the book. The edition number. Place of publication: Publisher, Publication year. Example: Eisen HN. Immunology: an Introduction to the Principles of Molecular and Cellular Immune Response. 5th ed. New York: Harper and Row, 1974.

Book chapters: The author(s) surname of the chapter initial(s) letter of the name. Section title. In: Surname of editor(s) initial (s) letter of first name(s) ed / eds. The name of the book. Edition number. Place of publication: Publisher, yea of publication: The first and last page numbers of the chapter.

- Example: Weinstein L. Swarts MN. Pathogenic properties of invading microorganisms. In: Sodeman WA Jr, Sodeman WA, eds. Pathologic Physiology: Mechanism of Disease. Phidelphia. WB Saunders, 1974:457-72. Web address: If a "web" address is used as the reference address, the web address date should be given in brackets with the address. The DOI (Digital Object Identifier) number must be provided, when a web access article used in the text as a reference.

Congress papers: Entrala E, Mascaro C. New structural findings in Cryptosporidium parvum oocysts. Eighth International Congress of Parasitology (ICOPA VIII) October, 10-14, Izmir-Turkey. 1994.

Thesis: Bilhan Ö. Experimental investigation of the hydraulic characteristics of labyrinth weir. Master Thesis, Science Institute of Firat University, 2005.

GenBank / DNA sequence analysis: DNA sequences of genes and heredity numbers should be given as references in the article. For more information, check "National Library of Medicine" and "National Center for Biotechnical Information (NCBI)".

Figure and Tables: Each table or figure should be printed on a separate sheet, the top and bottom lines and if necessary column lines must be included.

Tables should be numbered like "Table 1." and the table title should be written above the top line of the table. Explanatory information should be given in footnotes, not in the title and appropriate icons $\left({ }^{*},+,++\right.$, etc. $)$ should be used.

Photos should be in "jpeg" format. In case the quality of the photos is not good for publication, the originals can be requested.

12. Research articles should have up to 40 references.

13. In reviews, it is preferred to have not more than two authors. Author(s) must have done research and published articles previously on this subject; they should discuss their experience and use as reference in the review. Reviews should have Turkish and English titles, abstracts (it should contain minimum 250, maximum 400 words) and key words. Reference numbers for the review should be maximum 60 .

14. Case reports should have a maximum of seven pages of text.

Case report should have a Turkish and English title, abstract, keyword(s) and also introduction, case description and discussion sections should be given. Number of references should be maximum 20 .

15. Letters to Editor: Written to make criticisms, additions to previously published articles or scientific updates are published after review and assessment of the Editorial Board. Letters should not exceed one page of text and must be supported with up to 10 references.

16. The articles which do not comply with the journal rules are not accepted.

17. Authors should keep a copy of the article that they submit. 


\section{TÜRK HIJYEN VE DENEYSEL BIYOLOJI DERGISI}

\section{YAYIN İLKELERI}

- Türk Hijyen ve Deneysel Biyoloji Dergisi, Türkiye Halk Sağlığı Kurumu yayın organıdır. Dergi üç (3) ayda bir çıkar ve dört (4) sayıda bir cilt tamamlanır.

- Dergide biyoloji, mikrobiyoloji, enfeksiyon hastalıkları, farmakoloji, toksikoloji, immünoloji, parazitoloji, entomoloji, kimya, biyokimya, gıda, beslenme, çevre, halk sağlığı, epidemiyoloji, patoloji, fizyopatoloji, moleküler biyoloji, genetik, biyoteknoloji ile ilgili alanlardaki özgün araştırma, olgu sunumu, derleme, editöre mektup türündeki yazılar Türkçe ve İngilizce olarak yayımlanır.

- Dergiye, daha önce başka yerde yayımlanmamıs ve yayımlanmak üzere başka bir dergide inceleme aşamasında olmayan yazılar kabul edilir.
- Dergi Yayın Kurulu tarafindan uygun görülen yazılar, konu ile ilgili en az iki Bilimsel Danışma Kurulu Üyesinden olumlu görüş alındığında yayımlanmaya hak kazanır. Bu kurulların, yazının içeriğini değiştirmeyen her türlü düzeltme ve kısaltmaları yapma yetkileri vardır.

- Yazıların bilimsel ve hukuki sorumluluğu yazarlara aittir.

- Yazarlar araştırma ve yayın etiğine tam olarak uyum göstermelidir.

- Dergide yayımlanan yazıların yayın hakkı Türk Hijyen ve Deneysel Biyoloji Dergisi'ne aittir. Yazarlara telif ücreti ödenmez.

\section{YAZAR(LAR) IÇIN MAKALE KONTROL LISTESI}

- Bütün yazarlarca isim sırasına göre imzalanmış telif hakkı devir formu eksiksiz olarak dolduruldu.

- Yazar isimleri açık olarak yazıldı.

- Her yazarın bağlı bulunduğu kurum adı, yazar adının yanına numara verilerek başlık sayfasında belirtildi.

- Yazışmalardan sorumlu yazarın adi, adresi, telefon-faks numaraları ve e-posta adresi verildi.

- Türkçe ve İngilizce başlıklar ile kısa başlık yazıldı.

- Türkçe ve İngilizce özetlerin kelime sayısı (300-500 arası) kontrol edildi.

- Türkçe ve İngilizce anahtar kelimeler (MeSH ve Türk Tip Terimleri Sözlüğüne uygun) verildi.

- Tüm kısaltmalar gözden geçirildi ve standard olmayan kısaltmalar düzeltildi.

- Metin içerisinde geçen orijinal Latince mikroorganizma isimleri italik olarak yazıldı.

- Metin içerisinde bahsedilen birimlerin sembolleri the Système International (SI)'e göre verildi.

- Yazılar "miş'li geçmiş" zaman edilgen kip ile yazıldı.
- Metnin tamamı 12 punto Times New Roman karakteri ile çift aralıkla yazıldı.

- Metin sayfanın yalnız bir yüzüne yazılarak her bir kenardan $2,5 \mathrm{~cm}$ boşluk birakıldı.

- Tablolar, şekiller yazım kurallarına uygun olarak ve her biri ayrı bir sayfada verildi.

- Fotoğraflar JPEG formatında aktarıldı.

- Kaynaklar cümle sonlarında parantez içinde ve metin içinde kullanım sırasına göre ardışı sıralandı.

- Kaynaklar, makale sonunda metin içinde verildiği sırada listelendi.

- Kaynaklar gözden geçirildi ve tüm yazar adları, ifade ve noktalamalar yazım kurallarına uygun hale getirildi.

Ayrıca aşağıda belirtilen maddeleri dikkate alınız.

- Etik kurul onayı alındı.

- Bilimsel kuruluş ve/veya fon desteği belirtildi.

- Kongre/Sempozyumda sunumu ve sunum türü belirtildi.

- Varsa teşekkür bölümü oluşturuldu. 


\section{EDITORIAL POLICY}

- The Turkish Bulletin of Hygiene and Experimental Biology is a publication of the "Public Health Institute of Turkey (Türkiye Halk Sağlı̆̆ Kurumu)" of Ministry of Health. The Journal is published every three months and one volume consists of four issues.

- The journal publishes biology, microbiology, infectious diseases, pharmacology, toxicology, immunology, parasitology, entomology, chemistry, biochemistry, food safety, environmental, health, public health, epidemiology, pathology, pathophysiology, molecular biology, genetics, biotechnology in the field of original research, case report, reviews and letters to the editor are published in Turkish and English.

- Articles which are not previously published in another journal or not currently under evaluation elsewhere can be accepted for the journal.
- Articles approved by the Scientific Committee and Editorial Board are eligible to be released after receiving at least two positive opinions from the Scientific Committee members. Those committees have the authority to make all corrections and abbreviations but not to change the content of the article.

- The authors have the all the scientific and legal responsibilities of the articles.

- The authors must fully obey the ethics of research and publication.

- The copyright of the article published in the Turkish Bulletin of Hygiene and Experimental Biology belongs to the Journal. Copyright fee is not paid to the authors.

\section{CHECKLIST OF THE ARTICLE FOR AUTHOR(S)}

- Copyright transfer form is completed in full and signed by all authors according to the name order.

- Author names are written clearly.

- Affiliated institutions of the all authors are given on the title page by the number stated after the author's name.

- The name, address, phone-fax numbers and mail address of the author responsible for correspondence are given.

- Turkish, English titles and short title are written.

- The number of words in Turkish and English abstracts (between $300-500)$ is checked.

- Turkish and English keywords (according to MeSH) are given.

- All abbreviations are reviewed and non-standard abbreviations are corrected

- Original Latin names of microorganisms are written in italic.

- Symbols are mentioned according to the units in the Système International (SI).

- The article is written in passive mode and given one of the "past perfect, present perfect or past " tenses.

- Text is written in 12 pt Times New Roman characters and with double line spacing.
- Text is written only on one side of the page and has $2.5 \mathrm{~cm}$ space at each side.

- Tables and figures are given on each separate page according to the writing rules.

- Photos are in JPEG format.

- References are given at the end of the sentence in brackets and are listed in order of use in the text.

- References are listed at the end of the article in the order given in the text.

- References are reviewed, and the name of all authors, spelling and punctuation are controlled according the writing rules.

Furthermore, please check.

- "Ethics Committee Approval" is given.

- Support to a study by a fund or organization is mentioned.

- Congress / Symposium presentations and the type of presentation are stated.

- Acknowledgement is given, if there is. 
Türk Hijyen ve Deneysel Biyoloji Dergisi'ne www.turkhijyen.org adresinden online olarak makale gönderilebilir.

Submissions can be made online at the address www.turkhiiyen.org to Turkish Bulletin of Hygiene and Experimental Biology.

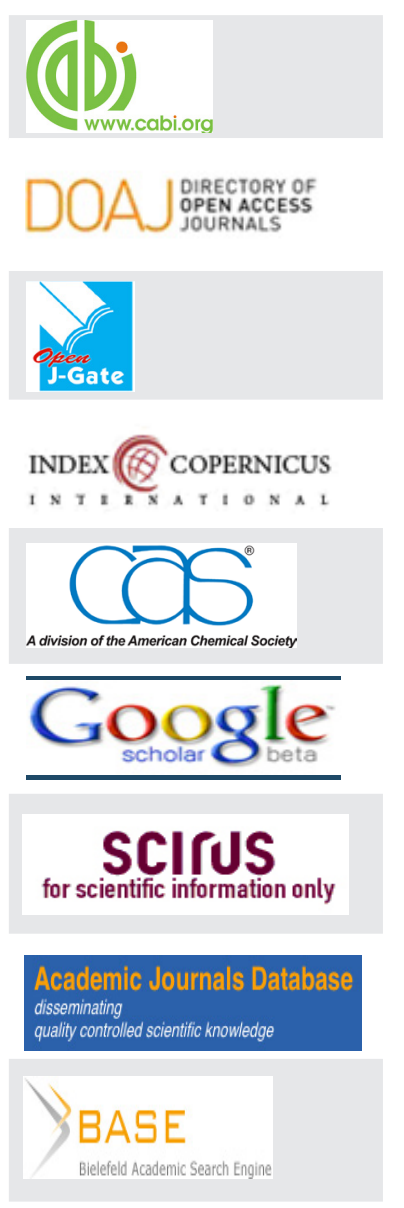

\section{Nen Jour \\ - Electronic Journals \& Newsletters •}

\section{EBSCO Electronic HOST Service}

Türk Hijyen ve Deneysel Biyoloji Dergisi (Turk Hij Den Biyol Derg); CAB Abstracts (Abstracts on Hygiene and Communicable Diseases, Diagnosis of Human Diseases, Tropical Diseases Bulletin, Global Health, AgBiotech, Veterinary Abstracts, Food Contamination, Residues and Toxicology, Human Toxicology and Poisoning), DOAJ (Directory of Open Access Journals), Index Copernicus, CAS (Chemical Abstracts Service), Google Scholar, Google, Open J-Gate, Ulrichsweb and Serials Solutions, NewJour, Genamics JournalSeek, Academic Journals Database, Scirus Scientific Database, Ovid Link Solver, BASE (Bielefeld Academic Search Engine), EBSCOhost Electronic Journals Service (EJS), Libsearch, Medoanet, SCOPUS, CrossRef, Türkiye Atıf Dizini, Akademik Türk Dergileri İndeksi, Türk - Medline ve TUBITAK-ULAKBIM Türk Tip Dizini’nde dizinlenmektedir.

The Turkish Bulletin of Hygiene and Experimental Biology (Turk Hij Den Biyol Derg) is indexed in CAB Abstracts (Abstracts on Hygiene and Communicable Diseases, Diagnosis of Human Diseases, Tropical Diseases Bulletin, Global Health, AgBiotech, Veterinary Abstracts, Food Contamination, Residues and Toxicology, Human Toxicology and Poisoning), DOAJ (Directory of Open Access Journals), Index Copernicus, CAS (Chemical Abstracts Service), Google Scholar, Google, Open J-Gate, Ulrichsweb and Serials Solutions, NewJour, Genamics JournalSeek, Academic Journals Database, Scirus Scientific Database, Ovid Link Solver, BASE (Bielefeld Academic Search Engine), EBSCOhost Electronic Journals Service (EJS), Libsearch, Medoanet, SCOPUS, CrossRef, Türkiye Atıf Dizini, Turkish Academic Journals Index, Türk - Medline, and TUBITAK - ULAKBIM Türk Tip Dizini.

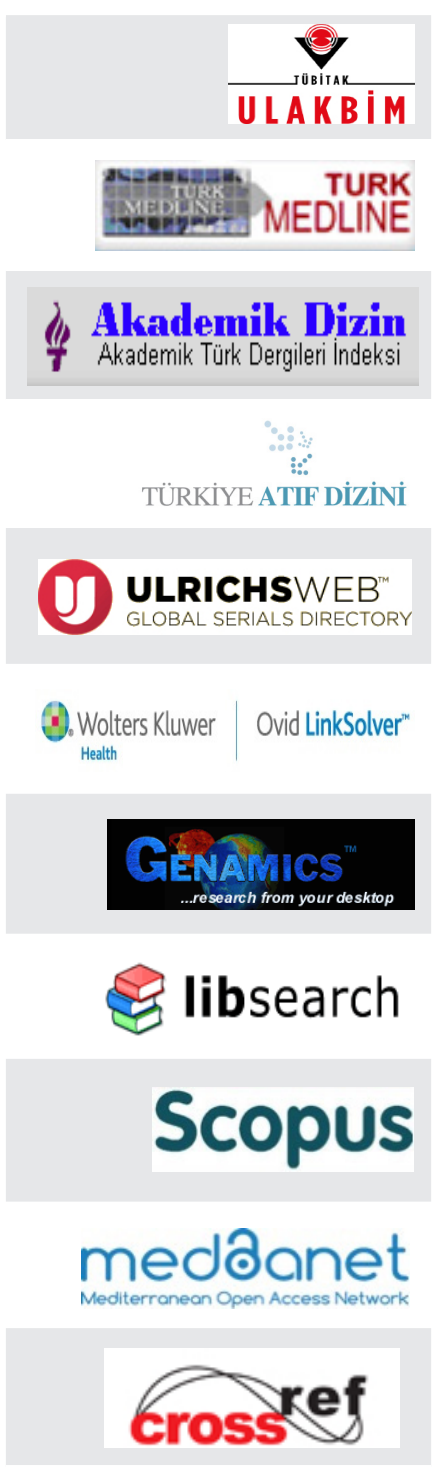

\section{İ L E T I Ş İ M \\ CORRESPONDENCE}

Türkiye Halk Sağlığı Kurumu

Türk Hijyen ve Deneysel Biyoloji Dergisi
Public Health Institution of Turkey

Turkish Bulletin of Hygiene and Experimental Biology

Sağlık Mahallesi Adnan Saygun Caddesi No: 55 Refik Saydam Yerleşkesi 06100 Sıhhiye/ANKARA - TÜRKIYE Tel: 03125655579

Faks: 03125655591

e-posta: turkhijyen@thsk.gov.tr http: www.thsk.gov.tr

www.turkhijyen.org 



\section{iÇINDEKILER / CONTENTS}

\section{Editöre Mektup / Letter to the Editor}

1. Human brucellosis in Thailand: Reported cases summary

Tayland'daki insan brusellozisi: Rapor edilmiș vakaların özeti

Joob BEUY, Viroj WIWANITKIT

Doi: 10.5505/TurkHijyen.2016.10846 (Dili: “IIngilizce" - Language: “English”)

\section{Araștırma Makalesi / Original Article}

2. Clinical characteristics and incidence of bacterial and viral pathogens in patients hospitalized with community acquired pneumonia in childhood in Konya between October 2008 and February 2010 Konya'da Ekim 2008 - Şubat 2010 tarihleri arasındaki çocukluk çağında toplum kökenli pnömoni tanısı ile hastaneye yatırılan hastalarda bakteriyel ve viral etkenlerin insidansı ve klinik özellikleri Sadiye SERT, Melike EMIROĞLU, Uğur ARSLAN, Osman KOÇ, Rahmi ÖRS Doi: 10.5505/TurkHijyen.2016.86547 (Dili: "İngilizce" - Language: "English")

3. Genotoxic and cytotoxic effects of formic acid on human lymphocytes in vitro Formik asidin insan lenfositleri uizerindeki in vitro genotoksik ve sitotoksik etkisi Pınar AKSU, Gökhan NUR, Süleyman GÜL, Ayșe ERCiYAS, Zeynep TAYFA, Tülay DiKEN ALLAHVERDi, Ertuğrul ALLAHVERDi Doi: 10.5505/TurkHijyen.2016.82621 (Dili: "IIngilizce" - Language: "English")

4. Sinop İlindeki hamsi ve zargana balıklarından Vibrio spp. izolasyonu ve karakterizasyonu Isolation and characterization of Vibrio spp. from anchovy and garfish in the Sinop province Cumhur AVŞAR, İsmet BERBER, Ahmet Kenan YILDIRIM

Doi: 10.5505/TurkHijyen.2016.58815 (Dili: "Türkçe" - Language: "Turkish")

5. 2013 yılında Muğla ili Marmaris ilçesinde görülen Staphylococcus aureus enterotoksin kaynaklı gıda zehirlenmesinin değerlendirilmesi

Evaluation of food poisoning of Staphylococcus aureus enterotoxin source in 2013 in the Marmaris district of Muğla, Turkey

Celal TUTUŞ, Demet BÖREKÇi, Gürcan PARCIKLI, Fehminaz TEMEL, Mustafa Bahadır SUCAKLI Doi: 10.5505/TurkHijyen.2016.79847 (Dili: "Türkçe" - Language: “Turkish')

6. İzmir'de sağlık kurumlarına yemek üretim ve dağıtım hizmeti veren bir firmada çalışanların gıda hijyeni ile ilgili bilgi ve davranışları

The knowledge and behaviour of workers on food hygiene who worked in a company providing catering and distribution service to the health institutions in Izmir

Şadan KÖKSAL, Ahmet SOYSAL, Gül ERGÖR, Gülşah KANER

Doi: 10.5505/TurkHijyen.2016.39129 (Dili: "Türkge" - Language: "Turkish")

7. İstanbul'un sivrisinek faunası ve Culex pipiens larvalarının Bacillus cinsi bakterilere karşı duyarııı̆ı The mosquito fauna of Istanbul and susceptibility of Culex pipens larvae to Bacillus spp. bacteriae Erdal POLAT, Serdar Mehmet ALTINKUM, Fadime YILMAZ, Sema TURAN-UZUNTAŞ, Yaşar BAĞDATLI Doi: 10.5505/TurkHijyen.2016.48254（Dili: "Türkçe" - Language: "Turkish")

\section{Olgu Sunumu / Case Report}

8. Fascioliasis tanısında hekimlerde ERCP yerine serolojik test farkındalığı yaratmak: Olgu sunumu To create awareness of serological tests instead of ERCP for fascioliasis diagnosis among physicians: A case report

Ayșegül AKSOY-GÖKMEN, Bayram PEKTAŞ, Mehmet CAMCI, Celal BUĞDACI, Erkan YULA, Selçuk KAYA, Mustafa DEMIRC

Doi: 10.5505/TurkHijyen.2016.93196 (Dili: "Türkçe" - Language: “Turkish")

Derleme / Review

9. Aşı epidemiyolojisi: Aşı etkililiği için epidemiyolojik çalışma tasarımları

Vaccine epidemiology: Epidemiologic study designs for vaccine effectiveness Can Huiseyin HEKIMOGLU

Doi: 10.5505/TurkHijyen.2016.28482 (Dili: "Türkçe" - Language: "Turkish")

10. Mantar enfeksiyonlarının serolojik tanısı

Serological diagnosis of fungal infections

Asuman BiRINCI, Yeliz TANRIVERDi-ÇAYCI

Doi: 10.5505/TurkHijyen.2016.74418 (Dili: "Türkçe" - Language: "Turkish")

11. Dijital PZR ve kullanım alanları

Digital PCR and applications

Ahmet CARHAN, Elif ERCAN, Tuğba YALCINKAYA

Doi: 10.5505/TurkHijyen.2016.48902 (Dili: “Türkçe" - Language: “Turkish") 



\title{
Human brucellosis in Thailand: Reported cases summary
}

\section{Tayland'daki insan brusellozisi: Rapor edilmiș vakaların özeti}

\author{
Joob BEUY ${ }^{1}, \quad$ Viroj WIWANITKIT ${ }^{2}$
}

\section{INTRODUCTION}

Brucellosis is an important zoonosis from cattle, swine, goats, sheep and dogs. It can be seen in many countries around the world (1). The patient can have wide spectrum of clinical feature and it is usually seen as a case of fever of unknown (FUO) origin (2). However, in Southeast Asia, this disease is extremely rare. In Thailand, a tropical country in Southeast Asia, brucellosis was firstly reported in 1970 and there were sporadic case reports after that $(3,4)$. Here, the authors have summarized on the clinical features of all available case reports of brucellosis in Thailand until now (October 2015). According to the searching in standard databases (PubMED, Scopus, Index Copernicus and Thai Index Medicus), there are at least 14 cases of human brucellosis reported from Thailand (4-10). All cases are also recorded due to the national disease notification system. All cases were adult patients except one. Prolonged FUO was the main clinical presentation seen in all cases. All adult cases also presented the complaint of weight loss. Lung complications (lobar pneumonia) could be seen in two cases. There was no problem of dermatological or gastrointestinal problem. The common laboratory finding in all cases was pancytopenia. Immunological test (serum agglutination test, cut off point 1:160) and blood culture helped to confirm diagnosis in all cases (no PCR test was available for diagnosis in studied reported cases). Standard antibiotic (doxycycline) treatment was used in all cases and it was proved to be effective for management of all Thai cases; complete recovery could be observed. Although there are few case reports on human brucellosis in Thailand. The high seropositivity (45.35\%) among general health people was recently reported (11) from a city where the outbreak took place in the previous year. In that recent study (11), "contact with labored or aborted goats" and "consumption of raw goat products" were approved as risk factors for human brucellosis in Thailand. In Thailand, brucellosis can be seen and the clinical pattern is concordant with the standard medical textbooks and pulished literatures. In Thailand, fever is the main clinical presentation and the respiratory problem is predominate. Goat is the major source of infection and $B$. melitensis the principal cause of human brucellosis. Although the cases are rare in Thailand, it is also similar to the previous report from other countries such as Turkey (12).

Key Words: Human, brucellosis, Thailand

${ }^{1}$ Sanitation 1 Medical Academic Center, BANGKOK, THAILAND

${ }^{2}$ Hainan Medical University, BANGKOK, THAILAND

İletişim/Corresponding Author: Joob BEUY Sanitation 1 Medical Academic Center, BANGKOK,- THAILAND

Tel : $6624658292 \quad$ E-posta/E-mail : beuyjoob@hotmail.com

DOI ID : 10.5505/TurkHijyen.2016.10846

Beuy J, Wiwanitk V. Human brucellosis in Thailand: Reported cases summary. Turk Hij Den Biyol Derg, 2016; 73(2): 99-100. 


\section{CONFLICTS of INTEREST}

The authors declare no conflicts of interest.

\section{REFERENCES}

1. Hasanjani Roushan MR, Ebrahimpour S. Human brucellosis: An overview. Caspian J Intern Med, 2015; 6: 46-7.

2. Mir T, Nabi Dhobi G, Nabi Koul A, Saleh T. Clinical profile of classical Fever of unknown origin (FUO). Caspian J Intern Med, 2014; 5: 35-9.

3. Subharngkasen S. Brucellosis in Thailand. Bull Off Int Epizoot, 1970; 73: 9-15.

4. Visudhiphan S, Na-Nakorn S. Brucellosis. First case report in Thailand. J Med Assoc Thai, 1970; 53: 289-93.

5. Paitoonpong L, Ekgatat $M$, Nunthapisud $P$, Tantawichien T, Suankratay C. Brucellosis: the first case of King Chulalongkorn Memorial Hospital and review of the literature. J Med Assoc Thai, 2006; 89: 1313-7.

6. Manosuthi W, Thummakul T, Vibhagool A, Vorachit M, Malathum K. Case report: Brucellosis: a re-emerging disease in Thailand. Southeast Asian J Trop Med Public Health, 2004; 35: 109-12.
7. Lapphral K, Leelaporn A, Vanprapar N, Chearskul $P$, Sawawiboon N, Wittawatmongkol O, Chokephaibulkit K. First case report of brucellosis in a child in Thailand. Southeast Asian J Trop Med Public Health, 2014; 45: 890-6.

8. Wongphruksasoong V. Investigation of brucellosis case and death in Chondaen district, Phetchabun province, Thailand, December 2009. W Epidemiol Surveil Rep, 2010; 41: 539-44.

9. Wiangcharoen R. Brucellosis in western region of Thailand. Reg 6-7 Med J, 2006; 25: 123- 9.

10. Laosiritaworn $\mathrm{Y}$, Hinjoy $\mathrm{S}$, Chuxnum $\mathrm{T}$, Vagus $\mathrm{A}$, Choomkasien P. Re-emerging human brucellosis, Thailand 2003. Bull Dept Med Serv, 2007; 32: 415-23.

11. Ekpanyaskul C, Santiwattanakul S, Tantisiriwat W, Buppanharun W. Factors associated with seropositive antibodies to Brucella melitensis in the Nakhon Nayok, Thailand. J Med Assoc Thai 2012; 95 Suppl 12:S40-6.

12. Kılıç S, Aalantaș Ö, Çelebi B, Pınar D, Babür C. Investigation of Seroprevalences of Q Fever, Brucellosis and Toxoplasmosis in Risk Groups in Hatay. Turk Hij Den Biyol Derg, 2007; 64: 16 - 21. 


\title{
Clinical characteristics and incidence of bacterial and viral pathogens in patients hospitalized with community acquired pneumonia in childhood in Konya between October 2008 and February 2010
}

\section{Konya'da Ekim 2008 - Şubat 2010 tarihleri arasındaki çocukluk çağında toplum kökenli pnömoni tanısı ile hastaneye yatırılan hastalarda bakteriyel ve viral etkenlerin insidansı ve klinik özellikleri}

\author{
Sadiye SERT ${ }^{1}, \quad$ Melike EMIROĞLU ${ }^{2}, \quad$ Uğur ARSLAN ${ }^{3}, \quad$ Osman KOÇ ${ }^{4}, \quad$ Rahmi ÖRS
}

\begin{abstract}
Objective: It was aimed to investigate clinical characteristics and incidence of bacterial and viral pathogens in patients who were hospitalized with the clinical diagnosis of community acquired pneumonia (CAP).

Method: In this study 91 patients at the ages between one month and six years who required hospitalization and were admitted to pediatrics clinics and pediatric emergency services of the Selçuk University Meram Medical Faculty, and also who did not use antibiotics for 48 hours before hospital admission and had the clinical diagnosis of CAP were investigated from October 2008 to February 2010. Demographic and clinic characteristics of the patients were recorded. Blood samples for complete blood count, erytrocyte sedimentation rate, C-reactive protein, procalcitonin, blood culture and nasopharyngeal aspirate samples for detection of the viral etiologies by real time polymerase chain reaction (RT-PCR) were taken at the time of hospital admission. Initial posteroanterior (PA) chest X-rays of all patients were checked.
\end{abstract}

Results: The agents of pneumonia were detected in $24.2 \%(22 / 91)$ but not in $75.8 \%(69 / 91)$ of our patients. Of 91 patients, $11(12.1 \%)$ were positive for viral infections, 9 (9.9\%) were positive for only bacterial infections, 3 (3.3\%) had viral coenfection, 2 (2.2\%) were positive for both viral and bacterial infections. Out of 11 viral positive patients, $7,2,1,2$, and 1 patients

\section{ÖZET}

Amaç: Bu çalışmada; toplum kökenli pnömoni tanısı (TKP) ile hastaneye yatırılan hastalarda bakteriyel ve viral etkenlerin insidansı ve klinik özellikleri araştırılması amaçlanmıştır.

Yöntem: 1 Ekim 2008-28 Şubat 2010 tarihleri arasında Selçuk Üniversitesi Meram Tıp Fakültesi Çocuk Poliklinikleri ve Çocuk Acil Servisine bașvuran ve yatırılarak tedavi edilmesi gereken, bașvurudan 48 saat öncesine kadar antibiyotik kullanmayan, klinik olarak TKP tanısı olan, yaşları 1 ay ile 16 yaş arasındaki toplam 91 hasta çalıșma kapsamına alındı. Bu hastaların demografik ve klinik özellikleri kaydedildi. Hastane bașvurusu esnasında tam kan sayımı, eritrosit sedimantasyon hızı, C-reaktif protein, prokalsitonin, kan kültürü için kan numuneleri ve viral etiyolojiyi gerçek zamanlı polimeraz zincir reaksiyonu (RT-PCR) ile saptamak amaciyla nazofaringeal aspirat numuneleri alındı. Tüm hastaların PA akciğer radyografileri kontrol edildi.

Bulgular: Hastaları \%24,2 (22/91)'sinde pnömoni etkeni saptanırken, \%75,8 (69/91)'inde herhangi bir pnömoni etkeni saptanamadı. 91 hastanın 11 (\%12,1)'inde viral enfeksiyon, dokuzunda $(\% 9,9)$ sadece bakteriyel enfeksiyon, üçünde (\%3.3) viral koenfeksiyon, ikisinde $(\% 2,2)$ hem virus hem de bakteri vard. Virus tespit edilen 11 hastanın yedisinde Parainfluenza (PIV) 2, ikisinde PIV 3, birinde adenovirus, ikisinde hem PIV3 hem

${ }^{1}$ Department of Pediatrics, Beyhekim State Hospital, KONYA, TURKEY

${ }^{2}$ Department of Pediatric Infectious Diseases, Faculty of Medicine, Selcuk University, KONYA, TURKEY

${ }^{3}$ Department of Microbiology, Faculty of Medicine, Selcuk University, KONYA, TURKEY

${ }^{4}$ Department of Radiology, Faculty of Medicine, Necmettin Erbakan University, KONYA, TURKEY

${ }^{5}$ Department of Pediatrics, Faculty of Medicine, Necmettin Erbakan University, KONYA, TURKEY

İletişim/Corresponding Author: Sadiye SERT

Department of Pediatrics, Beyhekim State Hospital, KONYA, TURKEY

Tel : +903322243000

E-posta/E-mail : sadiyesert@yahoo.com.tr

Geliş Tarihi / Received : 06.08.2015

Kabul Tarihi / Accepted : 01.01 .2016

DOI ID : 10.5505/TurkHijyen.2016.86547

Sert S, Emiroğlu M, Arslan U, Koç O, Örs R. Clinical characteristics and incidence of bacterial and viral pathogens in patients hospitalized with community acquired pneumonia in childhood in Konya between October 2008 and February 2010. Turk Hij Den Biyol Derg, 2016; 73(2): 101-10. 
were detected to have parainfluenza virus (PIV) 2, PIV 3, adenovirus, both PIV 3 and adenovirus, both PIV 2 and PIV 3, respectively. RSV, PIV 1 and human metapneumovirus (hMPV) were not detected in any of cases. Out of 11 bacteria positive patients, 5, 2, 1, 1, 1, and 1 patients were detected to have Staphylococcus epidermidis, S. saprophyticus, S. hominis, S. capitis, S. sobrinus and S. mitis. Also mixed viral-bacterial agent presence were detected in 2 (2.2\%) of our patients. Out of ninety one pneumonia patients those having their diagnosis clinically, 59 (64.7\%) had radiological signs.

Conclusion: Our study demonstrated the etiological influence of viral agents in CAP. Parainfluenza virus 2 was the most common viral agent among detected viruses in all age groups. Improving the etiological diagnosis of viral infections may avoid unnecessary the use of antibiotic. Further comprehensive and randomized controlled studies are needed to confirm our results.

Key Words: Childhood, etiology, community acquired pneumonia, real time-PCR adenovirus, birinde hem PIV2 hem de PIV3 tespit edildi. Hastaların hiçbirinde RSV, PIV1, hMPV saptanmadı. Bakteri tespit edilen 11 hastanın beșinde Stafilokokus epidermidis, ikisinde S. saprophyticus, birinde $S$. shominis, birinde $S$. capitis, birinde $S$. sobrinus ve birinde $S$. mitis tespit edildi. Hastaların ikisinde de viral-bakteriyel karma etken olduğu saptandı. Klinik olarak pnömoni tanısı alan 91 hastanın 59 (\%64,7)'unda radyolojik olarak pnömoni varlığı belirlendi.

Sonuç: Çalıșmamız TKP'de viral etkenlerin etiyolojik etkisini gösterdi. Parainfluenza virus 2 tüm yaş gruplarında en sık tespit edilen viral etkendi. Viral enfeksiyonların etiyolojik tanılarının iyileștirilmesi ile gereksiz antibiyotik kullanımından kaçınılabilir. Sonuçlarımızı doğrulamak için daha kapsamlı ve randomize kontrollü çalıșmalara gereksinim vardır.

Anahtar Kelimeler: Çocukluk çağı, etiyoloji, toplum kökenli pnömoni, gerçek zamanlı PZR

\section{INTRODUCTION}

Childhood community-acquired pneumonia (CAP) remains a leading cause of morbidity and mortality worldwide. The aetiological agents, patient age, clinical manifestations and seasonal occurrence of childhood CAP vary between countries. Rational antibiotic treatment requires knowledge of the most likely pathogens in each geographical region (1). Recent estimates from the World Health Organization (WHO) suggest that pneumonia is responsible for $20 \%$ of deaths in $<5$ years of age group, leading to 3 million deaths per year. Of these deaths, two thirds occur during infancy and more than $90 \%$ occur in the developing countries (2). There have been relatively few comprehensive studies of the viral and bacterial etiology of CAP in children. Identifying the cause of CAP in children is difficult for several reasons. The procedures used to confirm the pathogen, such as bronchoalveolar lavage and lung puncture for bacterial culture, are too invasive. The positive rate for blood cultures in pneumonia is only 0 to $5 \%$ in cases in developed countries (3-6).

Viral pathogens are gradually recognized as playing a major role in the etiology of lower respiratory tract infections (LRTIs), and are considered the predominant pathogens in CAP in preschool children (7). As these respiratory viral pathogens cause very similar clinical symptoms, differential diagnosis of the pathogens is required in appropriate sample. Monospecific PCR assays require separate amplification of each target and are therefore expensive and resource intensive. For clinical diagnosis, multiplex PCR has a significant advantage, as it permits simultaneous amplification of several viruses in a single reaction mixture, facilitating cost-effective diagnosis (8). Real-time PCR method was found to be more sensitive than cell culture on a range of different respiratory samples. 
The specificity of the real-time PCR was reported to be as high as $93 \%$ and the sensitivity as $100 \%$ (9). Thus, in our study we used multiplex real-time PCR method for diagnosis and differentiation of different viral agents.

Comprehensive information on the etiology of CAP is required for the formulation of treatment recommendations and the introduction of preventive measures. Evaluation of mixed infections and the relative importance of each potential pathogen may also contribute to improved understanding of the etiopathogenesis of CAP (10).

We aimed to investigate clinical characteristics and incidence of bacterial and viral pathogens in children aged one month to 16 years who were hospitalized for CAP.

\section{MATERIAL AND METHODS}

\section{Study design}

The study was a 17-months study. We evaluated to investigate clinical characteristics and incidence of bacterial and viral pathogens among children who were diagnosed and hospitalized for CAP. Patients aged one month to 16 years old diagnosed as CAP by inclusion criteria were recruited into the study. The study was approved by the local ethics committee, and written informed consent was obtained from parents of all patients. A patient was enrolled in the study if she/he met the following criteria (11). Fever with body temperature $>37.8^{\circ} \mathrm{C}$, respiratory rate more than average per age by WHO criteria, abnormal chest $\mathrm{x}$-ray together with signs of respiratory distress. Children were excluded if they were currently on antibiotic therapy or were admitted to hospital for more than 48 hours. Upon enrolment, demographic characteristics and baseline clinical data were recorded. Pulmonary auscultation findings of each patient were recorded with detailed physical examination.

\section{Study population}

From October 2008 to February 2010, 91 children aged one month to 16 years ( 44 girls and 47 boys, median age: 11 months) who were diagnosed as CAP and were hospitalized at department of pediatrics, Selcuk University Hospital, Konya, Turkey were included in the study.

\section{Radiology}

A senior radiologist, unaware of clinical and laboratory findings, reviewed all chest radiographs. Chest $\mathrm{x}$-rays were interpreted and recorded radiological findings such as normal chest radiography, consolidation, interstitial infiltration, peribronchitis, hiler/mediastinal lymphadenopathy, atelectasis, air broncogram, pleural effusion, and hyperinflation by the radiologist.

\section{Microbiology}

A nasopharyngeal sample was aspirated through a nostril and kept under $-80^{\circ} \mathrm{C}$ until virologic tests ( $\mathrm{n}$ $=91$ ) were done. Existence and genotyping of viruses (PIV type 1, 2 and 3, respiratory syncytial virus (RSV), adenovirus and human metapneumovirus) causing viral CAP were investigated with RT-PCR. Viral DNA isolation of a nasopharyngeal sample was made by using High Pure PCR Template Preparation (Cat.No. 11796828 001, Roche Diagnostic, Germany). RT-PCR device (LightCycler ${ }^{\circledR}$, Roche Diagnostic, Germany) was used for detection of pathogens. The virologic studies were carried out at the Department of Microbiology, Selcuk University Hospital, Konya.

Serum procalcitonin (PCT) levels were measured with BRAHMS PCT reactive (BRAHMS- Diagnostica, Berlin/ Germany). Assays were performed with Lumat LB 9501 immünoassay device (Roche Diagnostics GmbH, Mannheim, Germany) by using immünoluminometric method.

Serum C-reactive protein (CRP) levels were measured using Nephelometer 100 Device (Dade Behring Marburg, Germany).

Erythrocyte sedimentation rate (ESR) measurements were performed by using fully automated ESR assay device (Diesse Ves Cube 200, Diesse Diagnostica Senese SpA, Italy). 
Complete blood count (CBC) assays were performed with fully automated CBC device (CellDyne 3700, Abbott Diagnostics Division, Abbott Laboratories, Abbott Park IL, USA).

Blood cultures were obtained via BD Bactec Peds Plus/F vials before initiation of parenteral antibiotic therapy among all patients and incubated in automated blood culture system (Bactec 9240 BD, Becton Dickinson and Company, Sparks MD, USA). Isolated strains were also identified by using automated bacteria identification system (VITEK 2, Biomerieux, Marcy l'Etoile, France).

\section{Statistical analysis}

Data were reported as mean \pm SD, minimummaximum (range) or percent. After testing for normality with a one sample Kolmogorov-Smirnov test, differences in the means of variables were evaluated using both parametric (Student's t-test) and nonparametric tests (Mann-Whitney U-test) depending on the distribution of the variables. Categorical data were analysed with the chi-square test or Fischer's exact test. Results were considered significant if $p<0.05$. Statistical analyses were performed with the Statistical Package for Social Science program (SPSS version 15.0 for Windows; Chicago, IL).

\section{RESULTS}

The demographic and clinical features of the patients with CAP were shown in Table 1. The study included 47 (51.6\%) boys and 44 (48.4\%) girls. The median age of the patients was 11 months, ranging from 1 to 192 months. Nasal congestion and rhonchi were significantly frequent than in patients with viral infection when compared to those with bacterial pneumonia $(p=0.049, p=0.028)$. The agents of pneumonia were detected in $24.2 \%$ (22/91) with nasopharyngeal aspirate and blood culture but not in $75.8 \%(69 / 91)$ of our patients. Of 91 patients, 11 (12.1\%) were positive for viral infections, 9 (9.9\%) were positive for only bacterial infections, 3 (3.3\%) had viral coinfection, 2 (2.2\%) were positive for both viral and bacterial infections. Out of 11 viral positive patients, 7, 2, 1, 2, and 1 patients were detected to have parainfluenza virus (PIV) 2, PIV 3, adenovirus, both PIV 3 and adenovirus, both PIV 2 and PIV 3, respectively. RSV, PIV 1 and human metapneumovirus virus were not detected in any of cases. Out of 11 bacteria positive patients, 5, 2, 1, 1, 1, and 1 patients were detected to have Staphylococcus epidermidis, Staphylococcus saprophyticus, Staphylococcus hominis, Staphylococcus capitis, Streptococcus sobrinus and Streptococcus mitis. Also mixed viralbacterial agent presence were detected in 2 (2.2\%) of our patients. Table 2 shows viral and bacterial agents causing CAP in hospitalized children.

The mean body temperature on admission was $37.9 \pm 1.05^{\circ} \mathrm{C}$. Considering the pulmonary auscultation findings of the patients, crackles, rhonchi and wheezing were found in 85 (93.4\%), 54(59.3\%) and 38 (41.8\%) children, respectively. The median leukocyte count, CRP, PCT and ESR values were $9000 / \mathrm{mm}^{3}, 10.7$ $\mathrm{mg} / \mathrm{L}, 0.13 \mathrm{ng} / \mathrm{mL}, 13 \mathrm{~mm} / \mathrm{h}$, respectively.

The distributions of etiologic agents of communityacquired pneumonia according to different age groups were shown in Table 3. PIV-2 had the highest rate among detected viruses in all age groups. Adenovirus was detected only in one patient in 2-11 months of age group. Parainfluenza 3 were found in $<2$ and 2-11 months of age group. PIV-2 was the most common viral agent among $<2$ and 2-11 months of age group. Positive blood culture was detected the higher in $<2$ months of age group than those in other groups.

There was no statistically significant difference between viral and bacterial pneumonia groups with regard to ESR values $(p=0.669)$. Also, there was no statistically significant difference between viral and bacterial pneumonia groups with regard to $P C T$ values $(p=0.993)$. The radiological findings of patients with CAP were shown in Table 4. Chest $x$ ray showed notable alveolar 
Table 1. The demographic and clinical features of the patients with CAP

\begin{tabular}{|c|c|}
\hline \multicolumn{2}{|l|}{ Demographic features } \\
\hline Gender & \\
\hline Boy & $47(51.6) \dagger$ \\
\hline Girl & $44(48.4)$ \\
\hline \multicolumn{2}{|l|}{ Age (Month) } \\
\hline Median (Range) & $11(1-192)$ \\
\hline \multicolumn{2}{|l|}{ Residential area } \\
\hline Urban & 70 (76.9) \\
\hline Rural & $21(23.1)$ \\
\hline Underlying diseases & $14(15.4)$ \\
\hline \multicolumn{2}{|l|}{ Vaccination } \\
\hline Appropriate according to age & $91(100)$ \\
\hline At least one time hospitalising for lower respiratory tract infection & $18(19.8)$ \\
\hline Antibiotic therapy in the last month & $51(56)$ \\
\hline \multicolumn{2}{|l|}{ Age of mother (Year) } \\
\hline Mean & $28.4 \pm 5.6$ \\
\hline Median (Range) & $28(18-47)$ \\
\hline \multicolumn{2}{|l|}{ Age of father (Year) } \\
\hline Mean & $31.5 \pm 5.6$ \\
\hline Median (Range) & $31(22-49)$ \\
\hline Family history of atopy & $11(12.1)$ \\
\hline Upper respiratory tract infection in family during the last month & $61(67)$ \\
\hline Environment related to smoking & $39(42.9)$ \\
\hline \multicolumn{2}{|l|}{ Clinical presentation } \\
\hline Fever & $90(98.9)$ \\
\hline Cough & 90 (98.9) \\
\hline Wheezing & $71(78)$ \\
\hline İrritability & $65(71.4)$ \\
\hline Poor feeding & $61(67)$ \\
\hline Dyspnea & $58(63.7)$ \\
\hline Vomiting & $44(48.4)$ \\
\hline Cyanosis & $34(37.4)$ \\
\hline Rhinorrhoea & $30(33)$ \\
\hline Nasal congestion & $24(26.4)$ \\
\hline Productive cough & $23(25.3)$ \\
\hline Headache & $13(14.3)$ \\
\hline Sore throat & $13(14.3)$ \\
\hline Chest pain & $11(12.1)$ \\
\hline Abdominal pain & $11(12.1)$ \\
\hline \multicolumn{2}{|l|}{ Findings of physical examination } \\
\hline \multicolumn{2}{|l|}{ Body temperature $\left({ }^{\circ} \mathrm{C}\right)$} \\
\hline Median (Range) & $38(36.2-40)$ \\
\hline Mean & $37.9 \pm 1.05$ \\
\hline Crackles & $85(93.4)$ \\
\hline Tachypnea & $62(68.1)$ \\
\hline Rhonchi & $54(59.3)$ \\
\hline Cyanosis & $40(44)$ \\
\hline Tachycardia & $39(42.9)$ \\
\hline Nasal flaring & 39 (42.9) \\
\hline Wheezing & $38(41.8)$ \\
\hline Chest retraction & $36(39.6)$ \\
\hline Underweight (<\% 3) & $13(14.3)$ \\
\hline Short stature $(<\% 3)$ & 7 (7.7) \\
\hline
\end{tabular}

$\dagger: \mathrm{n}(\%)$, Data are shown as mean \pm standard deviation, median (range) or percent 
Table 2. The laboratory and microbiological features of the patients with CAP

\begin{tabular}{lc}
\hline Leukocyte count $\left(/ \mathrm{mm}^{3}\right)$ & \\
Median (Range) & $9000(2100-37600)$ \\
CRP (mg/L) & \\
Median (Range) & $10.7(1.3-106.7)$ \\
Procalcitonin (ng/ml) & \\
$\quad$ Median (Range) & $0.13(0.02-75.3)$ \\
ESR (mm/h) & $13(2-80)$ \\
$\quad$ Median (Range) & - \\
RSV & - \\
PIV 1 & $7(7.7) \dagger$ \\
PIV 2 & $2(2.2) \dagger$ \\
PIV 3 & $1(1.1) \dagger$ \\
Adenovirus & - \\
hMPV & \\
Viral coinfection & $2(2.2) \dagger$ \\
PIV3+adenovirus & $1(1.1) \dagger$ \\
PIV2+PIV3 & $11(12.1) \dagger$ \\
Positive blood culture & $1(1.1) \dagger$ \\
Staphylococcus hominis & $5(5.4) \dagger$ \\
Staphylococcus epidermidis & $2(2.2) \dagger$ \\
Staphylococcus saprophyticus & $1(1.1) \dagger$ \\
Staphylococcus capitis & $1(1.1) \dagger$ \\
Streptococcus sobrinus & \\
Streptococcus mitis & \\
\hline & \\
\hline & \\
\hline & \\
\hline
\end{tabular}

$\dagger: \mathrm{n}(\%)$, Data are shown as median (range) or percent

Table 3. The distributions of etiologic agents of community-acquired pneumonia according to age groups

\begin{tabular}{lccccc}
\hline $\begin{array}{l}\text { Age } \\
\text { (Month) }\end{array}$ & \multicolumn{4}{c}{ Number of patients $(\%)$} & \multirow{2}{*}{ Total } \\
\cline { 1 - 4 } Etiology & & Virus & $\begin{array}{c}\text { Positive } \\
\text { blood } \\
\text { culture }\end{array}$ & $\begin{array}{c}\text { Unknown } \\
\text { etiologic } \\
\text { agent }\end{array}$ & \\
\hline$<2$ & $2(12.5)$ & $4(25.1)$ & $10(62.5)$ & $16(17.6)$ \\
\hline $2-11$ & $6(19.4)$ & $4(12.9)$ & $21(67.7)$ & $31(34.1)$ \\
$12-23$ & $1(6.7)$ & $1(6.7)$ & $13(86.7)$ & $15(16.5)$ \\
$24-59$ & $0(0)$ & $2(12.5)$ & $14(87.5)$ & $16(17.6)$ \\
$>59$ & $2(15.4)$ & $0(0)$ & $11(84.6)$ & $13(14.3)$ \\
\hline Total & $11(12.1)$ & $11(12.4)$ & $69(75.8)$ & $91(100)$ \\
\hline
\end{tabular}

infiltration in 24 (26.3\%) of the 91 patients and interstitial infiltration in 35 (38.4\%). There was no statistically significant difference between viral and bacterial pneumonia groups with regard to length of hospitalization $(p=0.252)$. None of the children required mechanical ventilation or died.

\section{DISCUSSION}

Table 4. Chest $x$-ray findings of the patients with CAP

\begin{tabular}{lc}
\hline Radiological findings & $\mathbf{n}(\%)$ \\
\hline Normal & $28(30.8)$ \\
Intercystitial infiltration & $23(25.3)$ \\
Consolidation & $19(20.9)$ \\
Peribronchitis & $12(13.2)$ \\
Air bronchogram & $5(5.5)$ \\
Pleural effusion & $2(2.2)$ \\
Hiler/ mediastinal lymphadenopathy & $1(1.1)$ \\
Atelectasis & $1(1.1)$ \\
Hyperinflation & - \\
\hline
\end{tabular}

The present study showed causative infective agents and characteristics of hospitalized children with pneumonia. Real time-PCR as molecular diagnostic technique was used in our study to comprehensively study the viral etiology of CAP in hospitalized children who were 1 month to 16 years old. Using this method, infection with 6 viruses was investigated, and the presence of viral infection was identified in $12.1 \%$ of the patients. Bacterial infection was detected in 9 (9.9\%) of 91 patients. These results were less than previously reported etiological rates; in previous studies, the rate has been reported as $43 \%$ to $85 \%(6,12,13)$. Epidemiologic data related to pneumococcal diseases are very limited in Turkey, despite the fact that pneumococcus is the most important organism causing childhood bacterial diseases. The emergence and spread of resistant 
pneumococcal strains have led to an emphasis on the prevention of pneumococcal disease by vaccination. Routine vaccination with 7-valent pneumococcal conjugated vaccine (PCV-7) for children $<1$ year of age was agreed upon in Turkey at the end of 2008 and was included in the National Immunization Schedule in 2009. PCV-7 was used for 2 years in Turkey before being replaced by PCV-13 in November 2011. In 2010 and $2011,96 \%$ and $97 \%$ of the target population, respectively, were vaccinated with PCV-7 (14). In our study, Streptococcus pneumoniae was not detected in any of the blood cultures. It can depend on the Vaccine Schedule.

In clinical practice, it is important to distinguish between contamination and bloodstream infections to prevent unnecessary prescription of antimicrobial agents leading to a selection of antimicrobialresistant organisms $(15,16)$. Contamination is usually presumed if only one of at least two sets of blood cultures is positive for Coagulase-negative staphylococci, whereas true bloodstream infection is assumed if at least two blood cultures yield Coagulasenegative staphylococci $(17,18)$. Thus, we made the discrimination of yielding and contamination according to these data.

Iwane et al (19) showed that younger age (particularly $<1$ year), male gender, and presence of chronic underlying illness were associated with higher hospitalization rates for viral acute respiratory illness. In our study, the ratio of male to female was closed to 1 and $51.7 \%$ of patients were younger than 1 year of age. Our results were in accordance with previous studies' findings (20).

In a previous study by Juven et al (21), the most common symptoms were fever in $96 \%$, cough in $76 \%$, rhinorrhea in $48 \%$ and dyspnea in $37 \%$ of the patients with pneumonia. In this study, twenty-four percent of the patients had typical pneumonic rales/ crackles on auscultation. Decreased breathing sounds were found in $15 \%$ of patients, wheezing in $20 \%$ and rhonchi in $33 \%$ of the patients. Auscultation was normal in $28 \%$ of the patients. In our study, the most common symptoms were fever in $98.9 \%$ and cough in $98.9 \%$ of the patients. Auscultation findings of the patients, crackles, rhonchi and wheezing were found in $85(93.4 \%), 54(59.3 \%)$ and $38(41.8 \%)$ children, respectively.

Viruses have been most commonly associated with CAP diagnosed in infants and younger children (22). However, recent evidence suggests that, when sensitive detection methods are used, the prevalence of viral infections in older children with CAP is higher than previously thought (6). In our study, $12.1 \%$ of the patients were found to be infected with viruses. Cilla et al. had investigated 14 respiratory viruses in children aged less than 3 years old with CAP using molecular or immünochromatographic techniques and/or viral culture. In their study, at least one virus had been detected in $66.9 \%$ of the episodes (23).

Juvén et al. (6) reported a very high rate (62\%) of viral etiology in pediatric CAP. In their study, rhinovirus, detected by PCR, accounted for a large proportion of viral pneumonia. In our study, rhinovirus was not investigated.

RSV is accounted for an estimated 13, 3, and 0.4 RSV-associated hospitalizations per 1000 children who were younger than 1 year, 1 year of age, and in children 2 to 5 years of age, respectively (23). In our study, RSV was not detected. The cause for this is clearly unknown.

A recent study showed that the positive detection rate of adenovirus by RT-PCR was $0.63 \%$ in children with pneumonia (24). Similarly, in our study, adenovirus was detected only in one patient in 2-11 months of age group. However, this ratio is lower than in that reported in a study by Samransamruajkit et al. (25) in which adenovirus was detected in $6.6 \%$ of pneumonia patients.

Predictable parainfluenza-related hospitalization rates in the New Vaccine Surveillance Network study were $3.2,1.5$, and 0.4 per 1000 children younger than 1 year, 1 year, and 2 to $<5$ years of age, respectively (19). In our study, PIV-2 had the highest rate among 
detected viruses in all age groups. Parainfluenza 3 were found in $<2$ and 2-11 months of age group. PIV-2 was the most common viral agent among $<2$ and 2-11 months of age group.

Human metapneumovirus, a respiratory virus first isolated in the Netherlands in 2001, has been increasingly recognized as a common cause of acute respiratory tract infection in young children worldwide. Human metapneumovirus infection has been associated with a spectrum of clinical manifestations, ranging from influenza-like illness to bronchiolitis and pneumonia. Among children hospitalized for acute LRI in southern Israel during a 1-year period, human metapneumovirus was detected in $13 \%$ of the patients and was the third most common viral pathogen (26). In our study, human metapneumovirus was not detected.

In a previous study, in $27 \%$ of the episodes of childhood CAP multiple viral infections were detected. Infection severity was more in multiple viral infections than single viral infection due to the greater frequency of hospitalization (23). We also detected viral co-infection in 3 patients. In our study population, mixed infections were uncommon (3.1\%), although in previous studies mixed infections were reported as high as $23 \%$ of pneumonia cases in children (27).

The usefulness of PCT for distinguishing between bacterial and viral pneumonia has been analyzed in children but the data are also conflicting. Moulin et al. found that a PCT value of $1 \mathrm{ng} / \mathrm{ml}$ or greater had better specificity and sensitivity and higher positive and negative predictive values than CRP, IL-6 or white blood cell count for discriminating between bacterial and viral CAP in untreated children admitted to hospital (28). In a similar study Toikka et al. also reported high values of PCT in children with bacterial pneumonia, but with a large overlap between bacterial and viral pneumonia (29). In their study, Don et al. (30) concluded that the four nonspecific inflammatory markers, CRP, PCT, ESR, WBC count and their combinations have a limited role in the separation of bacterial from viral pneumonia in children. In particular, low levels considered as typical for viral infections were not able to rule out bacterial infection. In our study, we also found no statistically significant difference between viral and bacterial pneumonia groups with regard to ESR and PCT values.

In clinical practice, alveolar infiltrations on chest radiograph are often considered to indicate bacterial etiology of pneumonia, but clinical studies have failed to confirm this concept $(31,32)$. Virkki et al.(33) recently found that most children with alveolar infiltrates and, in particular, with lobar infiltrates, had bacterial pneumonia, whereas interstitial infiltrates were present in both viral and bacterial cases. In our study, there were alveolar infiltration in $24(26.3 \%)$ and interstitial infiltration in 35 (38.4\%) of the 91 patients.

This study, like others that investigated viral and bacterial pneumonia, has three major limitations: First of all, documentation of infection in the upper respiratory tract does not necessarily prove the etiological agent of pneumonia. However, in 69 of 91 cases no etiological agent was detected. The RT-PCR method is an extremely powerful and useful tool; however, if we had been included other viral agents including rhinovirus and human bocavirus detected by RT-PCR, numbers of diagnosed cases might be higher. We also did not investigate Mycoplasma pneumoniae serologically. Second, month-to-month variations in the prevalence of different pathogens may affect their association with CAP. Third, the other important limitation is that we only studied hospitalised patients, and the results cannot be generalised to outpatients with pneumonia.

In conclusion, our study demonstrated the etiological influence of viral agents in CAP. Parainfluenza virus 2 was the most common viral agent among detected viruses in all age groups. Improving the etiological diagnosis of viral infections 
may avoid unnecessary antibiotics and allow for preventive isolation of infected patients. Further larger and randomized controlled studies are needed to confirm our results.

\section{CONFLICTS of INTEREST}

The authors declare no conflicts of interest.

\section{REFERENCES}

1. Chiang WC, Teoh $\mathrm{OH}$, Chong CY, Goh A, Tang JP, Chay OM. Epidemiology, clinical characteristics and antimicrobial resistance patterns of communityacquired pneumonia in 1702 hospitalized children in Singapore. Respirology, 2007; 12: 254-61.

2. Mulholland K. Global burden of acute respiratory infections in children:implications for interventions. Pediatr Pulmonol, 2003; 36: 469-74.

3. Paisley JW, Lauer BA, McIntosh K, Glode MP, Schachter J, Rumack C. Pathogens associated with acute lower respiratory tract infection in young children. Pediatr Infect Dis, 1984; 3: 14-9.

4. Nohynek H, Eskola J, Laine E, Halonen P, Ruutu $P$, Saikku P, et al. The causes of hospital-treated acute lower respiratory tract infection in children. Am J Dis Child, 1991; 145: 618-22.

5. Gendrel D, Raymond J, Moulin F, Iniguez JL, Ravilly $\mathrm{S}$, Habib F, et al. Etiology and response to antibiotic therapy of communityacquired pneumonia in French children. Eur J Clin Microbiol Infect Dis, 1997; 16: 388-91.

6. Juvén T, Mertsola J, Waris M, Leinonen M, Meurman $O$, Roivainen $M$, et al. Etiology of communityacquired pneumonia in 254 hospitalized children. Pediatr Infect Dis J, 2000; 19: 293-8.

7. Sinaniotis CA, Sinaniotis AC. Community-acquired pneumonia in children. Curr Opin Pulm Med, 2005; 11: $218-25$.

8. Coiras MT, Pérez-Breña P, García ML, Casas I. Simultaneous detection of influenza A, B, and $C$ viruses, respiratory syncytial virus, and adenoviruses in clinical samples by multiplex reverse transcription nested-PCR assay. J Med Virol, 2003; 69: 132-44.
9. Templeton KE, Scheltinga SA, Beersma MF, Kroes AC, Claas EC. Rapid and sensitive method using multiplex real-time PCR for diagnosis of infections by influenza A and influenza B viruses, respiratory syncytial virus, and parainfluenza viruses $1,2,3$, and 4. J Clin Microbiol, 2004; 42: 1564-9.

10. McIntosh K. Community-acquired pneumonia in children. N Engl J Med, 2002; 346: 429-37.

11. World Health Organization. Technical bases for the WHO recommendation on the management of pneumonia in children at first level health facilities. World Health Organization, 1991, Geneva.

12. Heiskanen-Kosma T, Korppi M, Jokinen C, Kurki S, Heiskanen L, Juvonen $\mathrm{H}$, et al. Etiology of childhood pneumonia: serologic results of a prospective, population-based study. Pediatr Infect Dis J, 1998; 17: 986-91.

13. Wubbel L, Muniz L, Ahmed A, Trujillo M, Carubelli C, McCoig C, et al. Etiology and treatment of community- acquired pneumonia in ambulatory children. Pediatr Infect Dis J, 1999; 18: 98-104.

14. Ceyhan M, Ozsurekci Y, Gürler N, Ozkan S, Sensoy $\mathrm{G}$, Belet $\mathrm{N}$, et al. Distribution of Streptococcus pneumoniae serotypes that cause parapneumonic empyema in Turkey. Clin Vaccine Immunol, 2013; 20: 972-6.

15. Herwaldt LA, Geiss M, Kao C, Pfaller MA. The positive predictive value of isolating coagulasenegative staphylococci from blood cultures. Clin Infect Dis, 1996; 22: 14-20.

16. Rogers KL, Fey PD, Rupp ME. Coagulase-negative staphylococcal infections. Infect Dis Clin North Am, 2009; 23: 73-98. 
17. Seybold U, Reichardt C, Halvosa JS, Blumberg HM. Clonal diversity in episodes with multiple coagulase-negative staphylococcus bloodstream isolates suggesting frequent contamination. Infection, 2009; 37: 256-60.

18. Toldos CM, Yague G, Ortiz G, Segovia M. Assessment of multiple coagulase-negative staphylococci isolated in blood cultures using pulsed-field gel electrophoresis. Eur J Clin Microbiol Infect Dis, 1997; 16: 581-6.

19. Iwane MK, Edwards KM, Szilagyi PG, Walker FJ, Griffin MR, Weinberg GA, et al; New Vaccine Surveillance Network. Population-based surveillance for hospitalizations associated with respiratory syncytial virus, influenza virus, and parainfluenza viruses among young children. Pediatrics, 2004; 113: 1758-64

20. Nascimento-Carvalho $\mathrm{CM}$, Rocha $\mathrm{H}$, Benguigui $\mathrm{Y}$. Effects of socioeconomic status on presentation with acute lower respiratory tract disease in children in Salvador, Northeast Brazil. Pediatr Pulmonol, 2002; 33: 244-8.

21. Juvén T, Ruuskanen O, Mertsola J. Symptoms and signs of community-acquired pneumonia in children. Scand J Prim Health Care, 2003; 21: 52-6.

22. British Thoracic Society. Guidelines for the management of community-acquired pneumonia in childhood. Thorax, 2002; 57: 1-24.

23. Cilla G, Oñate E, Perez-Yarza EG, Montes $M$, Vicente D, Perez-Trallero E. Viruses in communityacquired pneumonia in children aged less than 3 years old: High rate of viral coinfection. J Med Virol, 2008; 80: 1843-9.

24. Lu MP, Ma LY, Zheng Q, Dong LL, Chen ZM. Clinical characteristics of adenovirus associated lower respiratory tract infection in children. World $\mathrm{J}$ Pediatr, 2013; 9: 346-9.
25. Samransamruajkit R, Hiranrat T, Chieochansin T, Sritippayawan S, Deerojanawong J, Prapphal $\mathrm{N}$, et al. Prevalence, clinical presentations and complications among hospitalized children with influenza pneumonia. Jpn J Infect Dis, 2008; 61: 446-9.

26. Wolf DG, Greenberg D, Kalkstein D, Shemer-Avni Y, Givon-Lavi N, Saleh N, et al. Comparison of human metapneumovirus, respiratory syncytial virus and influenza A virus lower respiratory tract infections in hospitalized young children. Pediatr Infect Dis J, 2006; 25: 320-4.

27. Michelow IC, Olsen K, Lozano J, Rollins N Epidemiology and characteristics of community acquired pneumonia in hospitalized children. Pediatrics, 2004; 113: 701-7.

28. Moulin F, Raymond J, Lorrot M, Marc E, Coste J, Iniguez JL, et al. Procalcitonin in children admitted to hospital with community acquired pneumonia. Arch Dis Child, 2001; 84: 332-6.

29. Toikka P, Irjala K, Juven T, Virkki R, Mertsola J, Leinonen $M$, et al (2000) Serum procalcitonin, C-reactive protein and interleukin-6 for distinguishing bacterial and viral pneumonia in children. Pediatr Infect Dis J, 19: 598-602.

30. Don $M$, Valent $F$, Korppi $M$, Canciani $M$. Differentiation of bacterial and viral communityacquired pneumonia in children. Pediatr Int, 2009; 51: 91-6.

31. Isaacs D. Problems in determining the etiology of community acquired childhood pneumonia. Pediatr Infect Dis J, 1989; 8: 143-8.

32. Korppi M , Kiekara O , Heiskanen-Kosma $\mathrm{T}$, Soimakallio $S$. Comparison of radiological findings and microbial aetiology of childhood pneumonia . Acta Paediatr, 1993 ; 82: 360-3.

33. Virkki R, Juven T, Rikalainene $H$, Svedström E, Mertsola J, Ruuskanen O. Differentiation of bacterial and viral pneumonia in children . Thorax, 2002; 57: 438-41. 


\title{
Genotoxic and cytotoxic effects of formic acid on human lymphocytes in vitro
}

\author{
Formik asidin insan lenfositleri üzerindeki in vitro genotoksik \\ ve sitotoksik etkisi
}

\author{
Pinar AKSU', \\ Gökhan NUR², \\ Süleyman GÜL', \\ Ayșe ERCIYAS ${ }^{1}$, \\ Zeynep TAYFA ${ }^{1}$, \\ Ertuğrul ALLAHVERDi ${ }^{4}$
}

\section{ABSTRACT}

Objective: Formic acid is an ubiquitous chemical constituent in the environment, being produced by sources as diverse as vegetation, ants, soil, vehicles, biomass burning, and photochemical reactions. The present work is focused on in vitro analysis of cytotoxic and genotoxic effects of formic acid, using cytogenetic tests such as the cytokinesis-block micronucleus assay (CBMN) and chromosomal aberration analysis, in human lymphocytes.

Method: This study was carried out using blood samples from healthy, non-smoking adults aged 18-22 years, of whom 10 were male and 6 were famale. Different concentrations $(0.07,0.1,0.2,0.3,0.4,0.5$, $0.8 \mathrm{mM}$ ) of formic acid was added to the lymphocyte culture test for chromosomal aberration (CA) analysis. Mitomycin-C $(0.3 \mathrm{mg} / \mathrm{ml})$ was used as the positive control. Human peripheral blood lymphocyte cells were treated with $20,40,60,80 \mathrm{mM}$ concentrations of formic acid for $48 \mathrm{~h}$. for the CBMN test. Mitomycin-C $(0.5 \mathrm{mg} / \mathrm{ml})$ was added to the Lymphocyte culture as a positive control. The present research was carried out to assess the cytotoxic and genotoxic effects of formic acid on human peripheral lymphocytes in vitro using the cytokinesis-block micronucleus assay (CBMN), as well as chromosomal aberration (CA) analysis.

\section{ÖZET}

Amaç: Formik asit, bitkiler, arılar, toprak, araçlar, gübre yanması ve fotokimyasal reaksiyonlar gibi çeșitli kaynaklarca üretilen ve çevrede yaygın olarak bulunan kimyasal bir bileșimdir. Mevcut çalıșma, insan lenfositlerinde sitokinez-blok mikronükleus tayini ve kromozomal aberasyon analizi gibi sitogenetik testler kullanarak formik asidin sitotoksik ve genotoksik etkilerinin in vitro analizine odaklanmıștır.

Yöntem: Bu çalışma 18-22 yaş arası 10'u erkek, 6'sı kadın sağlıklı, sigara kullanmayan yetișkinlerinden kan örnekleri kullanılarak gerçekleștirilmiștir. Lenfosit kültürüne kromozomal aberasyon (CA) testi için formik asidin farklı konsantrasyonları $(0,07$, $0,1,0,2,0,3,0,4,0,5,0,8 \mathrm{~mm})$ eklendi. Pozitif kontrol olarak mitomycin-C $(0,3 \mu \mathrm{g} / \mathrm{ml})$ kullanıldı. Sitokinez-blok mikronükleus tayini (CBMN) için, insan periferik kan lenfositleri 20, 40, 60, 80 mM derișimde formik asitle 48 saat ișleme tabi tutuldu. Lenfosit kültürüne, pozitif kontrol olarak mitomycin-C $(0,50 \mu \mathrm{g} / \mathrm{ml})$ eklendi. Bu araștırma, sitokinezblok mikronükleus tayinini (CBMN) ve kromozomal aberasyon (CA) analizini kullanarak in vitro insan periferal lenfositlerinde formik asidin sitotoksik ve genotoksik etkilerini değerlendirmek için yapılmıștır.

${ }^{1}$ Kafkas University, Faculty of Science and Arts, Department of Biology, KARS, TURKEY

${ }^{2}$ Gaziantep University, Vocational School of Higher Education in Islahiye, Department of Veterinary, GAZIANTEP, TURKEY

${ }^{3}$ Kafkas University, Faculty of Medicine, Department of General Surgery, KARS, TURKEY

${ }^{4}$ Kars State Hospital, Department of Orthopedic and Traumatology, KARS, TURKEY

$\begin{array}{lll}\text { Illetişim/Corresponding Author: Gökhan NUR } & \\ \text { Gaziantep University, Vocational School ofHigherEducation in Islahive, Department of Veterinary GAZIANTEP, TURKEY } & \text { Gelis Tarihi/Received : } 02.06 .2015 \\ \begin{array}{lll}\text { Tel : }+903428690300 & \text { E-posta/E-mail : gokhannur@gantep.edu.tr } & \text { Kabul Tarihi / Accepted : 03.12.2015 }\end{array}\end{array}$

DOI ID : 10.5505/TurkHijyen.2016.82621

Aksu P, Nur G, Gül S, Erciyas A, Tayfa Z, Diken-Allahverdi T, Allahverdi E. Genotoxic and cytotoxic effects of formic acid on human lymphocytes in vitro. Turk Hij Den Biyol Derg, 2016; 73(2): 111-20. 
Results: A significant increase was observed for induction of micronucleus frequency in all treatments of formic acid concentrations for $48 \mathrm{~h}$. comparing with the negative control and mitomycin C (MMC, $0.5 \mu \mathrm{g}$ / $\mathrm{ml}$ ) which was used as positive control. When compared with negative control and with mitomycin C (MMC, 0.3 $\mu \mathrm{g} / \mathrm{ml}$ ) which is used as positive control, it is observed that formic acid is rising the frequency of chromosomal aberration significantly at all appliance concantrations in $24 \mathrm{~h}$. The frequency of micronuclei and chromosomal aberrations increased in a dose dependent manner. The results showed that there were significant correlations between formic acid concentration and micronuclei frequency ( $r=0.92)$, numbers of necrotic cells $(r=0.95)$, and apoptotic cells $(r=0.91)$.

Conclusion: Our data provided evidence that there is a significant correlation between the concentration of formic acid and the following chromosomal aberrations: frequency of micronuclei, apoptotic cells, and necrotic cells in vitro.

Key Words: Formic acid, human lymphocyte culture, chromosomal aberration, micronucleus, cytotoxicity
Bulgular: Pozitif kontrol olarak kullanilan mitomisin C (MMC, 0,5 $\mathrm{gg} / \mathrm{ml}$ ) ile negatif kontrol karșılaștırıldığında formik asitin tüm dozları mikronükleus frekansını belirgin bir düzeyde arttırdığı gözlenmiștir. Pozitif kontrol olarak kullanılan mitomisin C (MMC, 0,3 $\mu \mathrm{g} / \mathrm{ml}$ )'nın negatif kontolle karșılaștırıldığında formik asidin 24 saatte tüm uygulama derișimlerinde, kromozomal aberasyonların sıklığını belirgin bir șekilde arttırdığı gözlenmiștir. Mikronükleus sıklığı ve kromozomal aberasyonlar, doza bağımlı olarak artmıștır. Sonuçlar formik asit konsantrasyonu, mikronükleus frekansı $(r=0,92)$, nekrotik hücrelerin sayısı $(r=0,95)$ ve apoptotik hücreler $(r=0,91)$ arasında anlamlı korelasyonların var olduğunu göstermektedir.

Sonuç: Verilerimiz, in vitro olarak formik asit konsantrasyonu ve mikronükleus frekansı, apoptotik hücreler ile nekrotik hücreler gibi kromozomal aberasyonlar arasında anlamlı bir korelasyon olduğu kanıtını sağlamıștır.

Anahtar Kelimeler: Formik asit, insan lenfosit kültürü, kromozomal aberasyon, mikronükleus, sitotoksisite

\section{INTRODUCTION}

Formic acid is the smallest member of the family of saturated monocarboxylic acids; it is a colorless liquid with a tangy odor and a density of 1.22 gram/ $\mathrm{cm}^{3}$. It dissolves in water, alcohol, and ether at all proportions. It burns when it comes in contact with skin. If it is heated to $160{ }^{\circ} \mathrm{C}$, it decomposes into carbon dioxide and hydrogen. It exists freely in nature in wood tar, nettles, ants, perspiration, urine and bouillon. Formic acid pollutes water and can spread through the air. Methyl alcohol is transformed into formaldehyde and formic acid by the body's metabolism; its toxicity is due to the acidosis resulting from the formic acid. As a result of this acidosis, nerve damage to the retina and, depending upon the degree of severity, blindness and eventually death may occur $(1,2)$. Most of the formic acid in tissues is oxidized via a tetrahydrofolic aciddependent pathway to $\mathrm{CO}_{2}$ and $\mathrm{H}_{2} \mathrm{O}$, such as in the liver, erythrocytes and kidneys (2). Literature on the carcinogenic and mutagenic effects of formic acid is quite limited. Tests of sister-chromatid exchange (SCE) performed on the typhimurium strains TA100, TA1535, TA97 and TA98 of Salmonella did not find it to be mutagenic. However, mutagenicity was reported in a test conducted on induction of sexlinked recessive lethal mutations as well as another study conducted on chromosomal aberrations $(3,4)$.

The present work is focused on in vitro analysis of cytotoxic and genotoxic effects of formic acid, using cytogenetic tests such as the cytokinesis-block micronucleus assay and chromosomal aberration analysis in human lymphocytes. 


\section{MATERIALS and METHODS}

This study was carried out using blood samples from healthy, non-smoking adults aged $18-22$ years, of whom 10 were male and 6 were famale. Donors provided written, informed consent at the time of donation for the use of their blood samples. Heparinized whole blood $(0.4 \mathrm{ml})$ was added to 5 $\mathrm{ml}$ chromosome medium (Biochrome). Cultures were incubated at $37{ }^{\circ} \mathrm{C}$ for $72 \mathrm{~h}$. Human lymphocytes were then exposed to different concentrations $(0.07,0.1,0.2,0.3,0.4,0.5,0.8 \mathrm{mM})$ of formic acid for $24 \mathrm{~h}$. A positive control (mitomycin-C), 0.3 $\mu \mathrm{g} / \mathrm{ml}$ ) was included in every experiment $(5,6)$. Lymphocytes were cultured in the dark for $72 \mathrm{~h}$, and metaphases were blocked during the last $2 \mathrm{~h}$ with colchicine at final a concentration of $0.06 \mu \mathrm{g} /$ $\mathrm{ml}$. Cells were collected by centrifuging ( $377 \mathrm{~g}, 10$ $\mathrm{min}$ ) and resuspended in a hypotonic $\mathrm{KCl}$ solution $(0.075 \mathrm{M})$ for $30 \mathrm{~min}$ at $37{ }^{\circ} \mathrm{C}$. At the end of this procedure, cells were centrifuged again and fixed in a cold methanol:acetic acid (3:1) mixture for $35 \mathrm{~min}$ at $+4{ }^{\circ} \mathrm{C}$. Following this process, cells were treated two times with fixative. Slides were then prepared by dropping concentrated cell suspensions onto the glass, followed by air drying. The air-dried slides were stained for 15-20 minutes with 5\% Giemsa stain $(\mathrm{pH}$ 6.8) prepared in a Sorensen buffer. One hundred metaphases per culture were analysed for the presence of chromosomal aberrations (CA). The number of CAs was obtained by calculating the percentage of metaphases at each concentration and treatment period that showed structural or numerical chromosome aberrations. Chromatid and chromosome breaks, chromosome exchange and chromatid unions, and polyploid cells were screened at all treatment concentrations $(5,7)$

For the micronucleus test in cultured human lymphocytes (CBMN), blood samples were added to 5 $\mathrm{ml}$ of chromosome medium (Biochrome). Cell cultures were incubated at $37{ }^{\circ} \mathrm{C}$ for $72 \mathrm{~h}$. Cytocalasin-B (6 $\mu \mathrm{g} / \mathrm{ml}$ ) was added to arrest cytokinesis at $44 \mathrm{~h}$ after culture initiation. Human lymphocytes were treated with different concentrations (20,40,60 and $80 \mathrm{mM}$ ) of formic acid for the CBMN test. Cells were exposed to the chemical for $48 \mathrm{~h}$ and harvested by centrifuging (167 $\mathrm{g}, 10 \mathrm{~min})$, and then the pellets were resuspended in a hypotonic solution of $0.075 \mathrm{M} \mathrm{KCl}$ for $5 \mathrm{~min}$ at $+4{ }^{\circ} \mathrm{C}$. The cells were centrifuged again and fixed in a cold methanol:acetic acid (3:1) mixture for $15 \mathrm{~min}$. The fixation procedure was administered three times. Formaldehyde $(1 \%)$ was added to the last fixative to preserve the cytoplasm. Slides were prepared by dropping concentrated cell suspensions onto the glass, followed by air drying. For CBMN analysis, staining was performed using $5 \%$ Giemsa $(\mathrm{pH}=6.8)$ prepared in a Sorensen buffer solution for 20-25 min. Slides were then washed in distilled water and dried at room temperature. Positive control (mitomycin- $C$ (MMC), $0.50 \mu \mathrm{g} / \mathrm{ml}$ ) was also maintained in the CBMN experiment (8).

Micronuclei were scored in 2000 binucleate lymphocytes for each subject (9). The nuclear division index (NDI) was evaluated using the following formula: $\mathrm{NDI}=(M 1+2(M 2)+3(M 3)+4(M 4)) / N$, where $M 1-M 4$ indicates the number of cells with 1 to 4 nuclei, and $\mathrm{N}$ indicate the total number of cells scored. The NDI of each cytochalasin B-treated culture was determined by screening 2000 interphase cells for the number of nuclei they contained (10).

Apoptotic and necrotic cells were identified with light microscopy according to morphological characteristics of the nucleus. In order to differentiate apoptotic cells from necrotic cells, we checked for the properties of necrotic cells, which exhibit a pale cytoplasm or loss of cytoplasm, numerous vacuoles, and a damaged/irregular nuclear membrane with a partially intact nuclear structure (9). 2000 cells were counted from each sample. The nuclear division cytotoxicity index $(\mathrm{NDCl})=(\mathrm{Ap}+\mathrm{Nec}+\mathrm{M} 1+2(\mathrm{M} 2)+$ $3(M 3)+4(M 4)) / N$ was evaluated according to Fenech (9), where $A p=$ the number of apoptotic cells, $\mathrm{Nec}=$ the number of necrotic cells, M1-M4 = the number of viable cells with 1-4 nuclei and $\mathrm{N}=$ the total number of cells scored. 
Statistical analyses of data were done using GraphPad InStat version 3.05 for Windows 95 (GraphPad Software, San Diego California USA). Chromosomal aberration frequencies in the cell cultures were analysed using Fisher's exact test. CBMN data were statistically analysed using the F-test for analysis of variance (ANOVA). The significance of differences between the negative control and the series of treatment groups were compared with Dunnett's t-test.

\section{RESULTS}

Compared to the other groups, an insignificant number of chromosomal aberrations was found in the metaphases obtained from the blood samples taken from the negative control group where no formic acid was added to the culture (Fig. 1A). Formic acid was administered to parallel cultures at doses of $0.8 \mathrm{mM}$
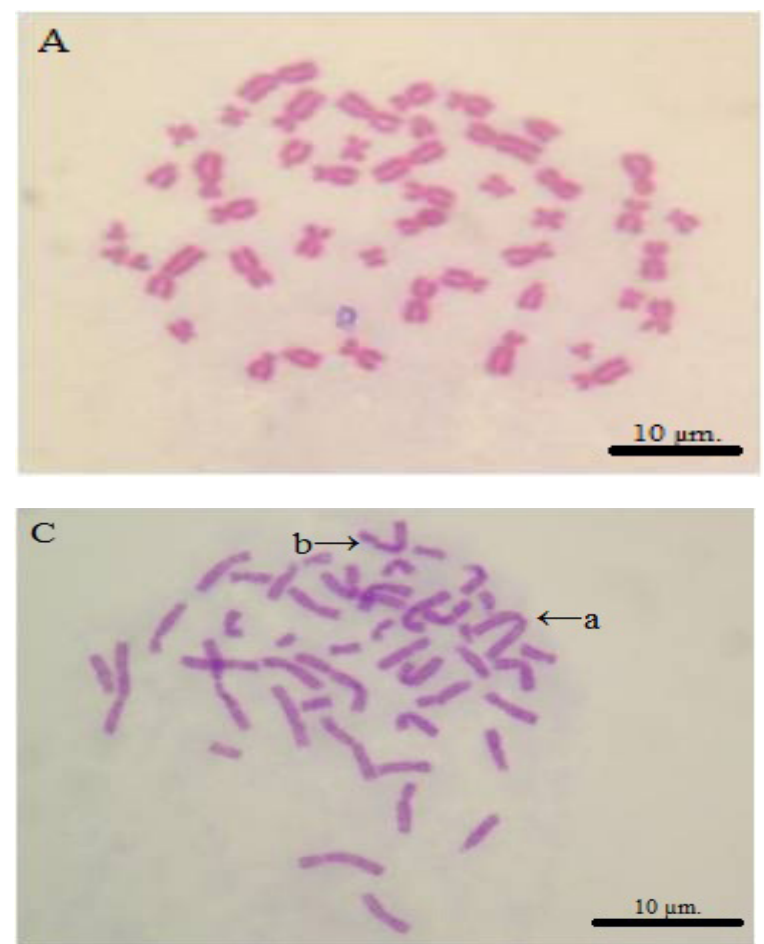

and lower $(0.07,0.1,0.2,0.3,0.4,0.5,0.8 \mathrm{mM})$. It was observed that division stopped fully in the culture where the number of metaphases was very low, and as a result the mitotic index was significantly decreased. After a trial was performed, it was determined that an activation period of 24 hours was suitable and that a longer period would prevent mitotic division. It was determined that the chromosomes condensed in the metaphases appeared filose and had a banded appearance (Fig. 1B). It was further observed that inhibition of cell division continued, but chromosomal anomalies in the metaphases were better visualized at an administered dose of $0.5 \mathrm{mM}$ formic acid (Fig. 1C). Banding in chromosomes and chromosome combinations were then observed more clearly. After treatment with $0.4 \mathrm{mM}$ formic acid, it was observed that mitosis was inhibited and that there were breaks in the chromatids and chromosomes in the metaphases (Fig. 1D).
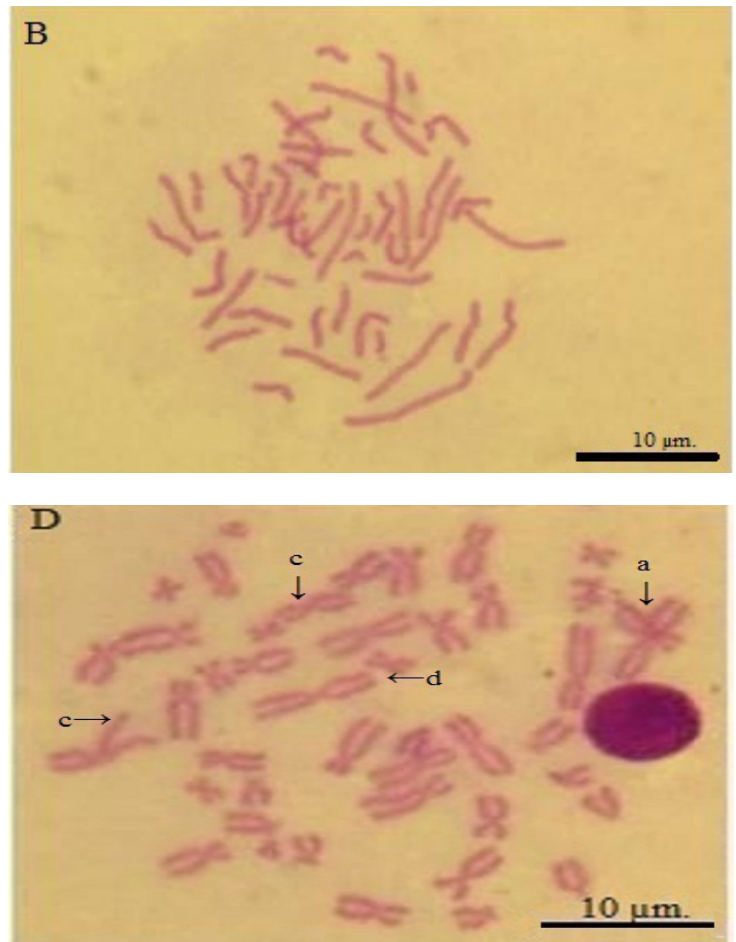

Figure 1. A. Metaphase plaque obtained from a normal individual. B. Metaphase plaque obtained from the culture that was administered $0.8 \mathrm{mM}$ of formic acid. C. Metaphase plaque obtained from the culture that was administered $0.5 \mathrm{mM}$ of formic acid: a. Chromosome combination, b. Chromosome break D. Metaphase plaque obtained from the culture that was administered $0.4 \mathrm{mM}$ of formic acid: a. Chromosome combination, c. Chromatide break, d. Chromatide combination. $(\times 1000$, Bar: $10 \mu \mathrm{m})$. 
A significant increase in the frequency of chromosomal aberrations was observed in some treatments with formic acid after $24 \mathrm{~h}$, compared to the negative control or treatment with mitomycin $C$, which was used as a positive control. The results obtained after treatment with $0.07 \mathrm{mM}$ formic acid were in line with the results obtained with the negative control. Polyploidy was observed at some formic acid treatment doses $(0.3,0.4 \mathrm{mM})$ and after treatment in the positive control (Table1).
Cytokinesis events were prevented by cytochalasin- $B$, and the frequencies of micronuclei and cell death (apoptosis and necrosis) were examined. Formic acid significantly increased the frequency of micronuclei in a dose dependent manner $(r=0.92)$. The nuclear division index (NDI) was calculated according to the number of nuclei present in the cells. Table 2 demonstrates that the NDI and nuclear division cytotoxicity index (NDCl) were significantly influenced by formic acid.

Table 1. Chromosome anomalies in human peripheral lymphocytes exposed formic acid for 24 hours

\begin{tabular}{|c|c|c|c|c|c|c|c|c|c|}
\hline \multirow{2}{*}{$\begin{array}{l}\text { Test } \\
\text { substance }\end{array}$} & \multicolumn{2}{|c|}{ Treatment } & \multicolumn{4}{|c|}{ Structural aberrations } & \multirow{2}{*}{$\begin{array}{c}\begin{array}{c}\text { Numerical } \\
\text { aberrations }\end{array} \\
\text { p }\end{array}$} & \multirow{2}{*}{$\begin{array}{l}\text { Frequency } \\
\text { of aberrant } \\
\text { cell } \pm \text { SEM (\%) }\end{array}$} & \multirow{2}{*}{$\begin{array}{c}\text { Mitotic index } \\
\quad \text { ISEM (\%) }\end{array}$} \\
\hline & Period (h) & Doses & ctb & csb & cse & $\mathrm{cu}$ & & & \\
\hline NC & 24 & 1 & 1 & 1 & - & - & - & $0.5 \pm 0.2$ & $4.3 \pm 0.3$ \\
\hline MMC $(\mu \mathrm{g} / \mathrm{ml})$ & 24 & 0.3 & 19 & 19 & 3 & 7 & 1 & $14.5 \pm 3.8^{*}$ & $1.7 \pm 1.2^{*}$ \\
\hline \multirow{6}{*}{$\begin{array}{l}\text { Formic acid } \\
(\mathrm{mM})\end{array}$} & \multirow{6}{*}{24} & 0.07 & 2 & 2 & - & 2 & - & $1.5 \pm 0.5$ & $4.3 \pm 1.2$ \\
\hline & & 0.1 & 3 & 3 & 1 & 4 & - & $2.7 \pm 0.6$ & $4.1 \pm 0.8$ \\
\hline & & 0.2 & 4 & 4 & 2 & 7 & - & $4.2 \pm 1.0$ & $4.0 \pm 1.0$ \\
\hline & & 0.3 & 7 & 7 & 2 & 13 & 1 & $9.7 \pm 4.5$ & $3.8 \pm 0.9^{*}$ \\
\hline & & 0.4 & 11 & 11 & 1 & 15 & 1 & $9.5 \pm 2.9$ & $3.5 \pm 0.5^{*}$ \\
\hline & & 0.5 & 12 & 12 & 3 & 18 & - & $11.3 \pm 3.0^{*}$ & $2.8 \pm 0.8^{*}$ \\
\hline
\end{tabular}

ctb: chromatid break, csb: chromosome break, cu: chromatid union, cse: chromosome exchange, nc: negative control (\%1 distilled water), MMC: $(0.3 \mu \mathrm{g} / \mathrm{ml}$ mitomycine-C (24 hours), p:polyploidy.

* $\mathrm{p}<0.05$ as compared to control. Fisher's Exact Test.

Table 2. The effects of formic acid on micronucleus frequency, nuclear division index, and nuclear cytotoxic division index in human lymphocytes cultures

\begin{tabular}{|c|c|c|c|c|c|c|c|c|c|c|}
\hline & \multicolumn{2}{|c|}{ Administration } & \multirow{2}{*}{$\begin{array}{l}\text { Number } \\
\text { of Cells } \\
\text { Counted }\end{array}$} & \multicolumn{4}{|c|}{$\begin{array}{l}\text { Distribution of } \mathrm{MN} \text { number } \\
\text { into Binuclear cells }\end{array}$} & \multirow{2}{*}{$\begin{array}{l}\text { MN/cell } \\
(\%) \pm S E M\end{array}$} & \multirow{2}{*}{ NDI } & \multirow{2}{*}{ NCDI } \\
\hline & Time (s) & Dose & & 1 & 2 & 3 & 4 & & & \\
\hline $\begin{array}{l}\text { Negative } \\
\text { Control }\end{array}$ & - & - & 2000 & 1 & 0 & 0 & 0 & $0.002 \pm 0.25$ & $1.981 \pm 0.34$ & $1.981 \pm 0.25$ \\
\hline PC (MMC) & 48 & $0.5 \mu \mathrm{g} / \mathrm{ml}$ & 2000 & 150 & 16 & 1 & 0 & $0.40 \pm 36.2$ & $1.332 \pm 0.83$ & $1.359 \pm 1.10$ \\
\hline \multirow{4}{*}{$\begin{array}{l}\text { Formic } \\
\text { acid }\end{array}$} & 48 & $20 \mathrm{mM}$ & 2000 & 7 & 1 & 1 & 1 & $0.02 \pm 1.50$ & $1.713 \pm 0.38^{*}$ & $1.731 \pm 0.48$ \\
\hline & 48 & $40 \mathrm{mM}$ & 2000 & 7 & 1 & 1 & 2 & $0.02 \pm 1.40$ & $1.678 \pm 0.55^{*}$ & $1.697 \pm 0.76$ \\
\hline & 48 & $60 \mathrm{mM}$ & 2000 & 9 & 3 & 2 & 2 & $0.04 \pm 1.63$ & $1.626 \pm 0.68^{*}$ & $1.667 \pm 0.47$ \\
\hline & 48 & $80 \mathrm{mM}$ & 2000 & 17 & 2 & 1 & 1 & $0.05 \pm 3.95$ & $1.592 \pm 0.78^{*}$ & $1.625 \pm 0.55$ \\
\hline
\end{tabular}

*Significantly different from the negative control $\mathrm{P}<0.05$ (Dunnett's t-test). NDI: Nuclear division index, NCDI: Nuclear cytotoxic division index, SEM: Standard error of the mean. 
$\mathrm{NDI}$ and NDCl values were lower than in controls. The lowest NDI values were observed in cultures treated with $80 \mathrm{mM}$ formic acid. All doses of formic acid administered increased micronuclei frequency and cell death to a statistically significant degree $(p<0.05)$ compared with the negative control group (Fig. 2A-G). There was a positive correlation between $M N$ frequency, the number of apoptotic cells $(r=0.91)$, and the number of necrotic cells $(r=$ 0.95) (Fig. 3A-C).

\section{DISCUSSION}

One of the most sensitive methods used to determine the genotoxic risks of mutagens and carcinogensisassessing the frequency of chromosome aberration (CA) in peripheral blood lymphocytes $(11,12)$. Chromosome aberrations occur due to damage at the DNA level. For instance, chromosome breaks may be caused by unrepaired double chain breaks in the DNA, and the emergence of chromosomes with a new structure may be caused by the false repair of chain breaks in the DNA (13). Due to the fact that the mechanisms by which chromosomal anomalies emergence resemble each another in different tissues, the level of anomalies in lymphocytes is considered to be an indication of the level of anomalies in other tissues that tend to be cancerous; thus it is also an indicator of cancer risk $(14,15)$. A high frequency of chromosomal aberrations may give an advance indication that there is a high risk of cancer, regardless of the reason that the increase in chromosome anomalies was triggered. Anomalies of both the chromatid type and chromosome type are indicators of cancer risk. However, there is evidence that chromosome anomalies are better determinants than chromatid anomalies $(15,16)$.

Another type of cytogenetic method used to determine genotoxicity and carcinogenicity is the micronucleus $(M N)$ test $(17,18)$. According to Bonassi et al. (19), a high $M N$ frequency in

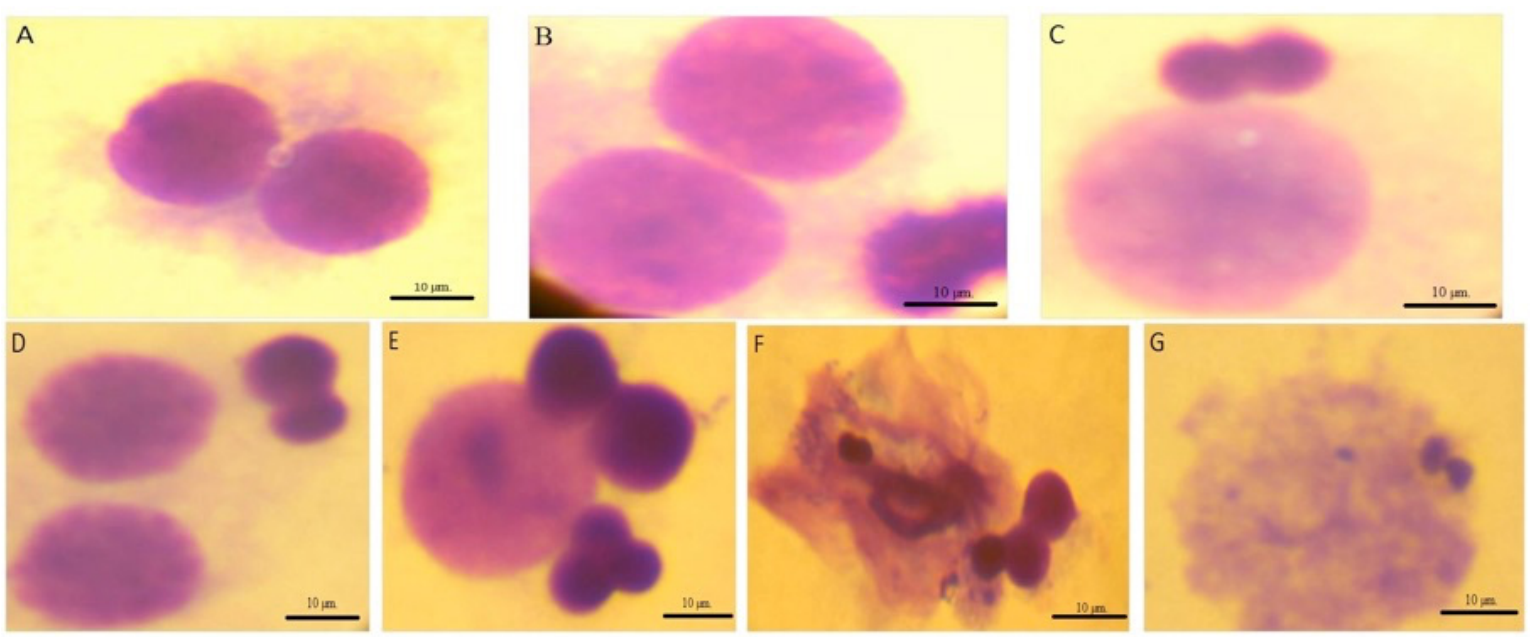

Figure 2. Micronucleus creations lymphocyte culture which was administered different doses of formic acid A. Double nucleus cell in which the normal cytokinesis was inhibited. B. Double nucleus cell containing one micronucleus the cytokinesis of which was inhibited ( $20 \mathrm{mM}$ formic acid, process of 48 hours). C. Single nucleus cell containing two micronuclei in which the cytokinesis was inhibited ( $40 \mathrm{mM}$ formic acid, process of 48 hours). D. Double nucleus cell containing two micronuclei in which the cytokinesis was inhibited (60 mM formic acid, process of 48 hours). E. A cell with multi micronuclei in which the cytokinesis was inhibited and which is entering apoptosis ( $80 \mathrm{mM}$ formic acid, process of 48 hours). F. An apoptotic cell ( $80 \mathrm{mM}$ formic acid, process of 48 hours). G. Necrotic cell with a pale cytoplasm, many small vacuoles and a cytoplasmic and nuclear membrane with corrupted structure ( $80 \mathrm{mM}$ formic acid, process of 48 hours). ( $\times 1000$, Bar: $10 \mu \mathrm{m})$. 
peripheral blood lymphocytes indicates a risk of cancer in humans. When the cytokinesis blockage micronucleus method was developed by Fenech and Morley (20), researchers began to examine the $M N$ in cells which have completed nuclear division. $M N$ are the small nuclei found apart from their sister nucleus, created during telophase due to the breaks in non-centric chromosomes or chromatid, and to the backwardness of all chromosomes or chromatides (slow chromosomes) (21). In a study that investigated the cytogenetic effect using the micronucleus, chromosomal aberration and sister chromatid exchange method, mercuric chloride has been shown to be a clastogenic chemical because of the variety of chromosomal abnormalities and the increase in the number of micronucleated cells (22).

Formic acid is used in carbonated drinks, fruit, vegetables and canned food as a preservative substance. Furthermore, it is commonly employed by honey producers to combat parasitic Varroa destructor mites in bee colonies (23). In one of their studies, Morita et al. tested the relationship between the clastogenic activities

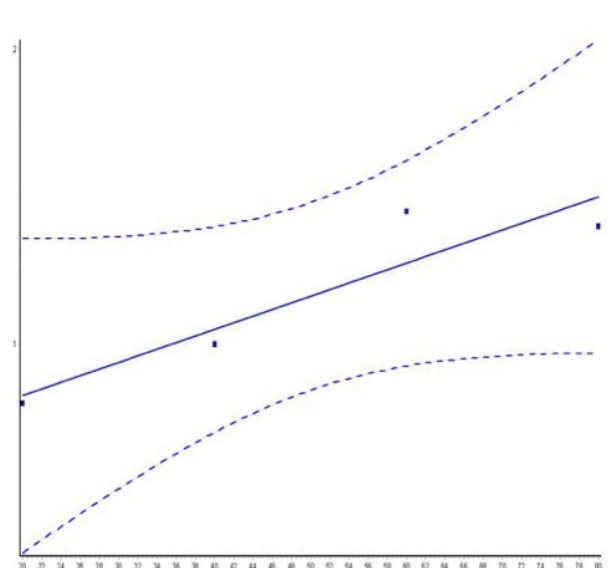

A.

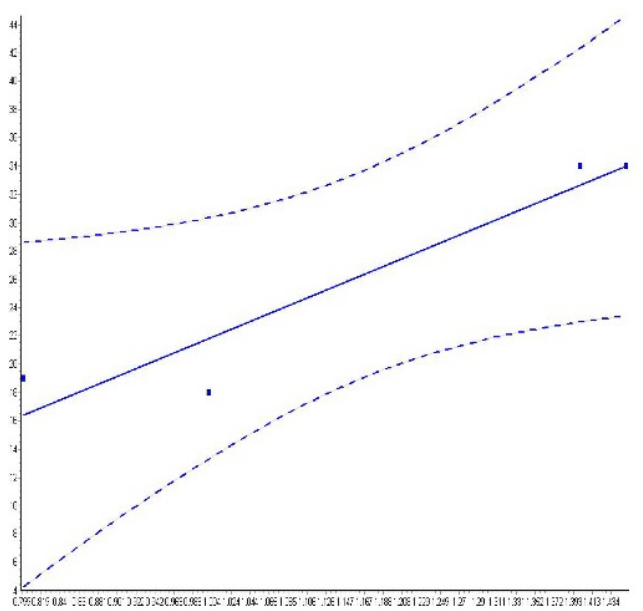

C.

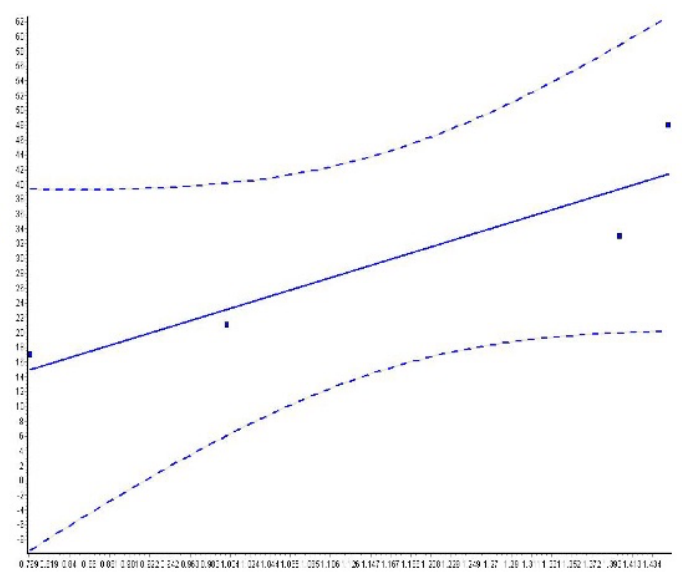

B.

Figure 3. A. Formic acid dose-micronucleus regression charts. B. MN frequency-apoptotic cell regression charts $(r=0.91, p<0.05)$. C. Micronucleus frequency-necrotic cell regression charts $(r=0.95, p<0.05)$. 
of formic acid and the $\mathrm{pH}$ of the medium using Chinese hamster ovary $\mathrm{K} 1$ cells. That study reported that acids stimulated chromosomal aberrations in the media with an original $\mathrm{pH}$ of 6. It was also determined that 12-16 mM concentrations of this acid exhibited toxicity in the media at $\mathrm{pH} 5.7$ or lower (3). In a study of the inhibitory effect of a mixture of propionic acid and formic acid on Salmonella pullorum, it was reported that the mixture of propionic acidformic acid caused a significant decrease in the number of colonies in the culture compared to the control (24). DNA adductions formed by various chemicals play an important role in cancer initiation. Wang et al. (25) reported that formic acid caused DNA adducts as well as hemoglobin $(\mathrm{Hb})$ adducts in mice.
The frequency of micronuclei in peripheral blood lymphocytes is used as a biomarker for chromosome damage (9). The doses that were used in the $M N$ and chromosomal aberration studies were different. The chromosomal aberration treatment dose is typically lower than the MN dose (26-28). However, in some studies the dose producing $M N$ was found to be equal to the dose causing chromosomal aberrations $(29,30)$. In our study, the dose that caused chromosomal aberrations was found to be lower than that which leads to micronuclei formation.

Conclusion: Our data provide evidence that there is a significant correlation between the concentration of formic acid and the following chromosomal aberrations: frequency of micronuclei, apoptotic cells and necrotic cells in vitro.

\section{ACKNOWLEDGEMENTS}

This study was conducted with support from the Kafkas University Scientific and Technological Research Fund (Project No: FEF-26).

Note: This study was previously presented at the 3rd National Veterinary Pharmacology and Toxicology Congress (With International Contribution), 29 September - 2 October 2010, pp.: 88-89, Aydın, Turkey.

\section{CONFLICTS of INTEREST}

The authors declare no conflicts of interest. 


\section{REFERENCES}

1. Barceloux DG, Bond GR, Krenzelok EP, Cooper H, Vale JA. American Academy of Clinical Toxicology practice guidelines on the treatment of methanol poisoning. Clin Toxicol, 2002; 40: 415-46.

2. Boeniger MF. Formate in urine as a biological indicator of formaldehyde exposure-a Review. Am Ind Hyg Assoc J, 1987; 48: 900-8.

3. Morita T, Takeda K, Okumura K. Evaluation of clastogenicity of formic acid, acetic acid and lactic acid on cultured mammalian cells. Mutation Research/Genetic Toxicology, 1990; 240 (3): 195-202.

4. Tephly TR. The toxicity of methanol. Life Sci, 1991; 48 (11): 1031-41.

5. Lazutka JR, Mierauskiene J, Slapsyte G, Dedonyte V. Genotoxicity of dill (Anethum graveolens L.), peppermint (Mentha x piperita L.) and pine (Pinus sylvestris L.) essential oils in human lymphocytes and Drosophila melanogaster. Food Chem Toxicol, 2001; 39: 485-92.

6. Roncada T, Vicentini VEP, Mantovani MS. Possible modulating actions of plant extracts on the chromosome breaking activity of $M M C$ and Ara-C in human lymphocytes in vitro. Toxicol in Vitro, 2004; 18: 617-22.

7. Yuzbasioglu D, Celik M, Yilmaz S, Unal F, Aksoy H. Clastogenicity of the fungicide a fugan in cultured human lymphocytes. Mutat Res-Gen Tox En, 2006; 604 (1-2): 53-9.

8. Demsia G, Vlastos D, Goumenou M, Matthopoulos DP. Assessment of the genotoxicity of imidacloprid and metalaxyl in cultured human lymphocytes and rat bone-marrow. Mutat Res-Gen Tox En, 2007; 634: $32-9$

9. Fenech M, Crot J, Turner J, Brown S. Necrosis, apoptosis, cytostasis and DNA damage in human lymphocytes measured simultaneously within the cytokinesis-block micronucleus assay: description of the method and results for hydrogen peroxide. Mutagenesis, 1999; 14: 605-12.

10. Eastmond DA, Tucker JD. Identification of aneuploidy-inducing agents using cytokinesisblocked human-lymphocytes and an antikinetochore antibody. Environ Mol Mutagen, 1989; 13 (1): 34-43.
11. Carrano AV, Natarajan AT. Considerations for population monitoring using cytogenetic techniques. Mutation Research/Genetic Toxicology, 1988; 204: 379-406.

12. Hagmar L, Brogger A, Hansteen IL, Heim S, Hogstedt B, Knudsen L, et al. Cancer risk in human predicted by increased levels of chromosomal aberrations in lymphocytes: Nordic study group on the health risk of chromosome damage. Cancer Res, 1994; 54 (11): 2919-22.

13. Savage JRK. Update on target theory as administered to chromosomal aberrations. Environ Mol Mutagen, 1993; 22: 198-207.

14. Albertini RJ, Anderson D, Douglas GR, Hagmar L, Hemminki K, Merlo F, et al. IPCS guidelines for the monitoring of genotoxic effects of carcinogens in humans. Mutat Res-Rev Mutat, 2000; 463: 111-72.

15. Boffetta P, Van der Hel O, Norppa H, Fabianova E, Fucic A, Gundy S, et al. Chromosomal aberrations and cancer risk: Results of a cohort study from central europe. Am J Epidemiol, 2007; 165: 36-43.

16. Norppa H, Bonassi S, Hansteen IL, Hagmar L, Stromberg U, Rossner P, et al. Chromosomal aberrations and SCEs as biomarkers of cancer risk. Mutat Res-Fund Mol M, 2006; 600(1-2): 37-45.

17. Fenech M. Biomarkers of genetic damage for cancer epidemiology. Toxicology, 2002; 181-182: 411-6.

18. Heddle JA, Cimino MC, Hayashi M, Romagna F, Shelby MD, Tucker JD, et al. Micronuclei as an index of cytogenetic damage: Past, present, and future. Environ Mol Mutagen, 1991; 18 (4): 277-91.

19. Bonassi S, Znaor A, Ceppi M, Lando C, Chang WP, Holland N, et al. An increased micronucleus frequency in peripheral blood lymphocytes predicts the risk of cancer in humans. Carcinogenesis, 2007; 28 (3): 625-31.

20. Fenech M, Morley AA. Measurement of micronuclei in lymphocytes. Mutation Research/Environmental Mutagenesis and Related Subjects, 1985; 147: 29-36.

21. Surralles J, Xamena N, Creus A, Marcos R. The suitability of the micronucleus assay in human lymphocytes as a new biomarker of excision repair. Mutation Research/Genetic Toxicology, 1995; 342: 43-59. 
22. Mahboob S, Al-Balwai HFA, Al-Misned F, Ahmad $Z$. Investigation on the genotoxicity of mercuric chloride to freshwater Clarias gariepinus. Pak Vet J, 2014; 34 (1): 100-3.

23. Fries I, Rosenkranz P. Number of reproductive cycles of Varroa jacobsoni in honey bee colonies. Exp Appl Acarol, 1996; 20: 103-12.

24. Al-Tarazi YH, Alshawabkeh K. Effect of dietary formic and propionic acids on Salmonella pullorum shedding and mortality in layer chicks after experimental infection. J Vet Med Infect Dis Vet Public Health, 2003; 50: 112-7.

25. Wang HF, Xu LH, Sun HF, Xue B, Liu YF, Peng S, et al. High binding of formic acid to biomacromolecules in mice. Nucl Instrum Meth B, 2004; 223: 745-9.

26. Celikler S, Yildiz G, Vatan O, Bilaloglu R. In vitro antigenotoxicity of Ulva rigida C. Agardh (Chlorophyceae) extract against induction of chromosome aberration, sister chromatid exchange and micronuclei by mutagenic agent MMC. Biomed Environ Sci, 2008; 21: 492-8.
27. Ogura H, Takeuchi T, Morimoto K. A comparison of the 8-hydroxydeoxyguanosine, chromosome aberrations and micronucleus techniques for the assessment of the genotoxicity of mercury compounds in human blood lymphocytes. Mut ResRev Gen Toxicol, 1996; 340: 175-82.

28. Panneerselvam N, Sinha S, Shanmugam G. Genotoxicity of the herbicide fluchloralin on human lymphocytes in vitro: chromosomal aberration and micronucleus tests. Mutation Research/Genetic Toxicology, 1995; 344: 69-72.

29. Anwar WA, Khalil MM, Wild CP. Micronuclei, chromosomal-aberrations and aflatoxin-albumin adducts in experimental-animals after exposure to aflatoxin B-1. Mut Res/Gen Toxicol, 1994; 322 : 61-7.

30. Buyukleyla M, Rencuzogullari E. The effects of thymol on sister chromatid exchange, chromosome aberration and micronucleus in human lymphocytes. Ecotox Environ Safe, 2009; 72: 943-7. 


\title{
Sinop Illindeki hamsi ve zargana balıklarından Vibrio spp. izolasyonu ve karakterizasyonu
}

\author{
Isolation and characterization of Vibrio spp. from \\ anchovy and garfish in the Sinop province
}

Cumhur AVŞAR ${ }^{1}, \quad$ İsmet BERBER ${ }^{1}, \quad$ Ahmet Kenan YILDIRIM $^{1}$

\section{ÖZET}

Amaç: Bu çalıșmada, Sinop İlindeki balıkçılardan temin edilen hamsi ve zargana balı örneklerinden izole edilen Vibrio türlerinin karekterizasyonu ile bu izolatların antibiyotik dirençlilikleri, plazmid DNA ve SDS-PAGE (sodyum dodesil sülfat poliakrilamid jel elektroforezis) toplam hücre protein profillerinin belirlenmesi amaçlanmıștır.

Yöntem: Balık örnekleri taze olarak alınmıș, buz üzerinde korunarak laboratuvara getirilmiș ve hemen analize alınmıștır. Balık örnekleri $25 \mathrm{~g}$ tartılarak zenginleștirme amacıyla \%3 $\mathrm{NaCl}$ içeren steril alkali peptonlu su $(225 \mathrm{~mL})$ besiyerine ilave edilmiş ve $37^{\circ} \mathrm{C}$ ' de 18-24 saat inkübasyona bırakılmıștır. İnkübasyon sonrası Tiyosülfat Sitrat Safra Sükroz (TCBS) agar besiyerinde gelișen sarı, yeșil veya mavi-yeșil koloniler Tripton Soya Agar (TSA) besiyerine ekilmiș ve izolatların daha sonraki tanımlaması için bir gece süreyle inkübe edilmiștir. İolatlar morfolojik, fizyolojik ve biyokimyasal testlere göre tanımlanmıștır. Bunlara ek olarak izolatların yedi farklı antibiyotiğe karșı dirençliliği disk-difüzyon yöntemiyle belirlenmiştir. Ayrıca, izolatların SDSPAGE hücresel protein ve plazmid DNA profilleri de çıkartılmıştır.

Bulgular: Toplam 44 adet balık örneği Vibrio türlerinin belirlenmesine yönelik çalıșılmıș ve morfolojik, biyokimyasal özellikleri yönünden incelenmiștir. Inceleme sonucunda; 12 adet Vibrio spp. belirlenmiștir.

\section{ABSTRACT}

Objective: In this study it was aimed to characterize the Vibrio species isolated from anchovy and garfish samples obtained from fishermen and to determine the antibiotic resistances, plasmide DNA and SDS-PAGE (sodium dodecyl sulphate polyacrylamide gel electrophoresis) whole cell protein profiles of these isolates.

Method: The fish samples were taken as fresh, kept in ice during transport to the laboratory and immediately taken for analysis. The fish samples weighed as 25 grams were added into $225 \mathrm{~mL}$ of sterile alkaline peptone water supplemented with $3 \% \mathrm{NaCl}$ broth for enrichment purpose and incubated at $37{ }^{\circ} \mathrm{C}$ for 18 to 24 hours. After incubation, yellow, green or blue-green colonies growing on Thiosulphate Citrate Bile Salt Sucrose (TCBS) agar were subcultured on Triptone Soya Agar (TSA) and incubated overnight for further identification of the isolates. The isolates were identified according to morphological, physiological and biochemical tests. Moreover, the resistances against seven different antibiotics of isolates were determined by disk-diffusion method. In addition, the SDS-PAGE cell protein and plazmid DNA profiles of isolates were determined.

Results: Totallly 44 fish samples were tested for determining Vibrio species and were analyzed according to their morphological, biochemical

* Bu çalıșma; 6. Ekoloji Sempozyumu'nda (6-9 Mayıs 2015, Sinop-TÜRKIYE) poster bildiri olarak sunulmuștur.

Sinop Üniversitesi, Fen-Edebiyat Fakültesi, Biyoloji Bölümü, SiNOP

İletişim/Corresponding Author : Cumhur AVŞAR

Sinop Üniversitesi, Fen-Edebiyat Fakültesi, Biyoloji Bölümü, SiNOP

Tel : +905384533639

E-posta/E-mail : cumhur.avsar@gmail.com

Geliș Tarihi / Received : 24.08.2015

Kabul Tarihi / Accepted : 04.01.2016

DOI ID : 10.5505/TurkHijyen.2016.58815

Avșar C, Berber I, Yıldınm AK. Sinop Ilinde ki hamsi ve zargana balıklarından Vibrio spp. izolasyonu ve karakterizasyonu. Turk Hij Den Biyol Derg, 2016 ; 73(2): 121-30. 
İolatların, seftazidime \%66,6, gentamisine \%25, tetrasikline $\% 16,6$, seftriazona $\% 91,6$, amikasine $\% 16,6$, ofloksine $\% 25$ ve penisilin G'ye $\% 58,3$ oranında antibiyotik dirençlikleri saptanmıștır. Ayrıca, test edilen izolatların MARI (Çoklu Antibiyotik Dirençlilik İndeks) değeri 0,41 oranında bulunmuștur. Vibrio spp. izolatlarının SDSPAGE toplam hücre protein profillerine göre olușturulan nümerik analiz $\% 80$ ve üzerinde benzerlik seviyesinde iki temel küme olușturmuştur. Vibrio spp. izolatların tümünde 1-4 plazmid DNA (1590 - 27000 bp aralığında) tespit edilmiștir.

Sonuç: Sonuç olarak, balıklar yakalandıktan sonra yeterince dondurularak, pișirilerek ve uygun şartlarda depolanarak; ayrıca paketleme esnasında çapraz bulașlara engel olunarak mikrobiyal enfeksiyonların önlenebileceğini söylemek mümkündür. Ayrıca, bakterilerden dolayı kıуı sularında meydana gelen bulașlar, deniz suyu kaynaklarının kalitesinde düșüşlere ve bu yolla da insan sağlığında riske ve ekonomik kayıplara yol açmaktadır. Çalıșmamız, sağlık için potansiyel risk olabilen ve balıklardan izole edilebilen, antibiyotiklere dirençli Vibrio spp. suşlarının varlığını göstermektir.

Anahtar Kelimeler: Vibrio, balık, SDS-PAGE, plazmid, antibiyogram properties. At the end of the analysis; 12 Vibrio species were determined. The isolates were resistant against to ceftazidime $66.6 \%$, gentamisine $25 \%$, tetracycline $16.6 \%$, ceftriaxone $91.6 \%$, amikacine $16.6 \%$, ofloxacine $25 \%$ and penicillin G 58.3\%. In addition, The MARI (Multiple Antibiotic Resistance Index) values of tested strains were found at the rate of 0.41 . The numerical analysis of SDS-PAGE whole-cell protein profiles of Vibrio spp. isolates revealed two major clusters at similarity levels of $80 \%$ and above. The $1-4$ plasmide (range $1590-27000 \mathrm{bp}$ ) in all of the isolates were determined.

Conclusion: As a result, it is possible to say that microbial infections can be prevented by adequate freezing and cooking, proper storage and processing after harvesting and avoidance of cross-contamination during fish handling. In addition, the coastal contamination due to bacteria leads to decline in the quality of seawater resources and so leads to risks to human health and economic losses. Furthermore, our study indicated that the presence of antibiotic resistant Vibrio spp. strains isolated from fishes might be potential risk for health.

Key Words: Vibrio, fish, SDS-PAGE, plasmide, antibiogram

\section{Gíriş}

Bakteriler; toprak, hava, su, hayvan ve bitki yüzeylerinde bulunurlar. Bazıları hastalık etkeni olmakla beraber çoğu zararsız ve organik atıkların geri dönüșümü sırasındaki yararlı etkileri ve birçok faydalı ürünü üretmeleri nedeniyle biyoteknolojide oldukça önemli bir yere sahiptirler. Vibrio cinsi; virgül veya kıvrık șekilli, Gram negatif, kamçılı, endospor olușturmayan, kapsülsüz, aerob veya fakültatif anaerob bakterilerden oluşur. Vejetatif formlar, tek bașına veya koloni șeklinde görülürler (1). Bu cinsin hücre büyüklüğü yaklașık 1-4 $\mu$ boyunda ve 0,3-0,6 $\mu$ enindedir. Genellikle $22{ }^{\circ} \mathrm{C}$ ile $40^{\circ} \mathrm{C}$ arası ideal büyüme sıcaklıklarıdır. Bu cinsin üyeleri, karbon ve azot kaynağı olarak mineral tuzları ve asparajin içeren besi-yerlerinde gelişme gösterirler (2). Vibrio türlerinin spor ve kapsülü olmadığından yeryüzünde farklı çevrelerde dağılıș göstermemektedirler. Vibrio cinsinin asıl habitatı tatlı su, asidik su, tuzlu su ve bu sularda yașayan organizmalardır (3). Vibrio türleri neredeyse tüm antimikrobiyal ilaçlara karșı yüksek duyarlılığa sahip olarak nitelendirilmișlerdir. Son on yıldır; insan, tarım alanı ve su ürünleri yetiștiriciliği aracılığıyla antimikrobiyallerin așırı kullanılmasından dolayı çoğu bakteri cinsinde antibiyotik dirençliliği ortaya çıkmıș ve zamanla değișim göstermiștir (4). 
Bu bakteri türleri, insanlarda ve hayvanlarda zorunlu patojen veya fırsatçı enfeksiyon etkenidirler (5). Bulaş olmuş içme suyu ve gidalarla bulaşan ve șiddetli diyarenin etkeni olan Vibrio cholerae'da bu gurubun üyesidir. Ayrıca V. parahaemolyticus ve $V$. fluvialis, akut gastroenteritin sebepleridir. Bunların dıșında, V. alginolyticus, V. vulnificus, ve $V$. damsela; yara enfeksyionları, septisemi, menenjit gibi ekstraintestinal enfeksiyonlarla ilișkilendirilmiștir. Yapılan araștırmalar, Vibrio spp. ile meydana gelen yara enfeksiyonlarının sebebinin, hastaların tuzlu ve hafif tuzlu su ile temas ettiğinde oluștuğunu göstermiștir (6). Insanlarda genellikle barsak hastalığı bulașı; su, kabuklu deniz hayvanları veya diğer deniz ürünlerinin tüketimi ile ilişkilendirilmiștir (7).

Sinop Ilinde yıl boyunca balık; turizme açık bir yer olması nedeniyle yazın ayrıca midye çok tüketilmektedir. Şehir merkezinin yarım ada șeklinde denize kıyısının olması nedeniyle atıkların direkt denize ulaștığı ve su ürünlerinin mikrobiyal kirliliğe maruz kaldığı bilinmektedir. Tüm bu durumlar göz önüne alınarak bu çalıșmada, Sinop Illi'nde satışa sunulan hamsi ve zargana balık örneklerinden; Vibrio spp. biyokimyasal testlerle karakterize edilmesi, toplam hücre protein profillerinin SDS-PAGE ile karşıllaştırılması, antibiyotik dirençliliklerinin tespit edilmesi ve ayrıca plazmid DNA profillerinin çıkarılması amaçlanmıştır.

\section{GEREÇ ve YÖNTEM}

Sinop ilinde gün içinde avlanan hamsi ve zargana balıkları Eylül 2014 - Ocak 2015 tarihleri arasında satıcılardan alınmış ve buz içerisinde laboratuvara getirilmiștir.

Bu çalıșma, Sinop Üniversitesi, Fen-Edebiyat Fakültesi, Moleküler-Mikrobiyoloji Laboratuvarında gerçekleștirilmiștir. Laboratuvara getirilen toplam 44 balık örneğinin iç organları atılarak geriye kalan kısımları 25 gram olacak șekilde ayarlanmıștır.

\section{Bakterilerin izolasyonu}

Balık örneklerini zenginleștirme amacıyla \%3 $\mathrm{NaCl}$ içeren alkali peptonlu sıvı (225 mL) besiyerine ilave edilmiş ve stomacherde homojenize edilerek $37{ }^{\circ}{ }^{\circ}$ 'de 18-24 saat inkübasyona bırakılmıștır. İnübasyon sonrası zenginleștirme besiyerinden TCBS Agar besiyerine çizme ekim yapılmış ve 37

${ }^{\circ} \mathrm{C}$ 'de 24 saat inkübasyona bırakılmıștır. İnkübasyon sonunda TCBS agar besiyerinde gelișen 2-3 mm çapında, yuvarlak, sarı, yeșil veya mavi-yeșil renkli koloniler șüpheli koloni olarak değerlendirilmiştir (2). Gram boyama sonrasında Gram negatif, düz veya kıvrık çomak şeklinde görülen kolonilere oksidaz testi yapılmış ve oksidaz pozitif sonuç veren şüpheli kolonilerden TSA besiyerine ekim yapılarak 37 ${ }^{\circ} \mathrm{C}$ 'de 24 saat inkübasyona bırakılmıștır. İnkübasyon sonrası bu koloniler indol, Voges-Proskauer (VP), jelatinaz aktivite, sitrat, nitrat, üre, karbonhidrat fermentasyon testi ve $\% 6 \mathrm{NaCl}$ 'de gelișebilmeleri incelenmiștir. TSA'dan alınan koloniden üç șekerli demir (Triple Sugar Iron-TSI) agar besiyerine ekim yapılarak $37^{\circ} \mathrm{C}$ ' de 24 saat inkübasyona bırakılmıștır. İnkübasyon sonunda biyokimyasal test sonuçları, laktoz, sükroz ve glikoz fermentasyonu, gaz ve hidrojen sülfür $\left(\mathrm{H}_{2} \mathrm{~S}\right)$ oluşumu değerlendirilmiștir (8).

\section{Antibiyogram testi}

İolatların antibiyotik dirençlilik testleri disk difüzyon tekniğine göre yapılmıştır (9). Taze kültürlerden $5 \mathrm{~mL}$ Mueller-Hinton Broth (MHB) besiyerinde $35 \pm 2{ }^{\circ} \mathrm{C}$ 'de 18 saat geliștirilmiștir. Gelișen kültürlerden 0,5 McFarland skalası esas alınarak yaklaşık olarak 1-2 x $108 \mathrm{kob} / \mathrm{mL}$ bakteri stok solüsyonları hazırlanmıș ve Mueller-Hinton Agar (MHA) besiyerine $100 \mu \mathrm{L}$ ekimleri yapılmıştır.

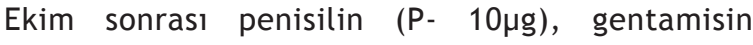
(Gen-10 $10 \mathrm{~g}$ ), seftazidim (Caz- $30 \mu \mathrm{g}$ ), tetrasiklin (Te- $30 \mu \mathrm{g})$, seftriazone (Cro- $30 \mu \mathrm{g})$, amikasin (Ak- $30 \mu \mathrm{g})$ ve ofloksasin (Ofx- $5 \mu \mathrm{g}$ ) antibiyotik 
diskleri besiyerlerine yerleștirilmiș ve 18 saat 35 $\pm 2{ }^{\circ} \mathrm{C}$ 'de geliștirildikten sonra olușan inhibisyon zonları milimetrik olarak ölçülmüștür. Zon çapları değerlendirmesinde Klinik ve Laboratuvar Standartları Enstitüsü (Clinical and Laboratory Standards Institute- CLSI) (10) tarafından Enterobacteriaceae grubu için belirtilen standartlar kullanılmıștır. Ayrıca izolatların test edilen antibiyotiklere karşı çoklu antibiyotik dirençlilik indeksleri (MARI) așağıda gösterilmiș olan ve Sarter ve ark. (11) tarafından belirtilen formüle göre hesaplanmıștır:

$M A R I=A /(B \times C)$

$A=$ Antibiyotiğe dirençli olanların toplam sayısı;

$\mathrm{B}=$ Çalışmada kullanılan antibiyotiklerin toplam sayısı;

$\mathrm{C}=$ Test edilen izolatların toplam sayısı.

\section{Toplam hücre proteinlerinin belirlenmesi}

Toplam hücre proteinlerin ekstraksiyonu için Laemmli (12)'nin SDS-PAGE yönteminde bazı değișiklikler yapılarak gerçekleștirilmiștir. Aktifleștirilen Vibrio spp. izolatlarından beșer $\mathrm{mL}$ TSB besiyerine ekilerek $37^{\circ} \mathrm{C}$ 'de 24 saat inkübasyona bırakılmıștır. İnkübasyon sonunda gelișen kültürler 12000 rpm'de 5 dk santrifüj (Hanil Science Industrial, HM-150 IV, Japan) edilmiș ve üst sıvı kısmı atılarak pelet üzerine $100 \mu \mathrm{L}$ serum fizyolojik ilave edilerek üç kez yıkanmıștır. Yıkama ișlemi sonrası kalan pelet üzerine $20 \mu \mathrm{L}$ örnek tamponu ilave edilmiş ve $80{ }^{\circ} \mathrm{C}$ 'de $5 \mathrm{dk}$ kaynatılarak çözünür proteinler ekstrakte edilmiștir. Örnekler elektroforez yapılıncaya kadar $-20{ }^{\circ} \mathrm{C}$ 'de saklanmıștır. Bakteri kültürlerinden ekstrakte edilen toplam hücre proteinleri, $1 \mathrm{~mm}$ kalınlığında dikey elektroforez tankında (Hoefer SE400, USA) \%4'lük toplayıcı jel boyunca 20 mA ile \%10'luk ayırıcı jelde 30 mA'lik sabit akım uygulanmıș ve comassie brillant mavi (R-250) boyası ile boyanarak belirlenmiștir. Yürütme ișlemi toplayıcı ve ayırıcı jel proteinlerin molekül ağırlıkları, marker (PageRulerTM Unstained Protein Ladder, Fermantas, SM0661) kullanılarak hesaplanmıștır.

\section{Plazmid DNA izolasyonu}

Plazmid DNA izolasyonu Sambrook ve ark. (13)'nın yönteminde bazı değișiklikler yapılarak gerçekleștirilmiștir. Aktif Vibrio spp. kültürleri 10 000 rpm'de ve 1 dk santrifüj edilmiștir. Santrifüj ișleminden sonra üst sıvı kısmı atılarak pelet içerisinde $100 \mu \mathrm{L}$ soğuk çözelti I (50 mM glikoz, 25 mM Tris-HCL - pH 8,0, 10 mM EDTA - pH 8,0) ile sulandırılıp karıștırılmıștır. Karıștırma ișleminden sonra üzerine $200 \mu \mathrm{L}$ çözelti II (\%1 SDS, 0,2 N NaOH) ilave edilerek tüp birkaç defa alt üst edilerek ve iyice karıșması sağlandıktan sonra $15 \mathrm{dk}$ buzda bekletilmiștir. Süre bitiminde 10000 rpm'de, 7 dk santrifüj ișlemi yapılmış ve üst sıvı kısmı alınarak fenol: kloroform (1:1) eklenerek karıștırma ișlemi yapılmıștır. Bu ișlem, plazmid DNA'nın protein kalıntılarından arınması için iki kez yapılmıștır. 10 000 rpm'de, 5 dk sanrifüj ișlemi sonrası üst sıvı kısım üzerine iki katı kadar soğuk saf etil alkol ekleyerek buz içerisinde $15 \mathrm{dk}$ bekletilmiștir. Süre bitiminden sonra 10000 rpm'de, 10 dk santrifüj işlemi yapılmış ve pelet üzerindeki alkol tamamen uçurulduktan sonra \%70'lik soğuk etil alkol ile yıkanmıștır. Yıkama ișleminden sonra alkolün tamamen uzaklașması sağlanmış ve $50 \mu \mathrm{L}$ TrisEDTA (TE) tamponu içerisinde çözülmüș ve analize kadar - $20{ }^{\circ} \mathrm{C}$ 'de saklanmıștır.

İzole edilen plazmid örneklerin agaroz jel elektroforezi için \%0,7'lik agaroz jeli (1X TBE (Tris Borat EDTA) tamponunda $5 \mu \mathrm{L}$ etidyum bromid eklenerek hazırlanmıștır. Plazmid örnekleri agaroz jel kuyucuklarına konulduktan sonra jel elektroforez cihazında (Thermo ScientificMS1509112955, UK) yürütme tamponu ile 80 voltluk sabit akımda ve yaklaşık 2,5-3 saat süre ile yürütme ișlemi yapılmıștır. Yürütme ișleminin bitiminde, jellerin fotoğrafları UV transillüminatörde (Cleaver-MicroDOC, UK) çekilmiștir. 


\section{Veri Analizi}

Protein profillerinin istatistiksel analizinde; jeller, yüksek çözünürlükle bir tarayıcı (HP Scanjet, G2410) kullanılarak bilgisayar ortamına aktarılmıștır. Ayrıca, plazmid DNA örneklerinin yürütüldüğü jellerin fotoğrafları UV transillüminatör (Cleaver-MicroDOC, UK) altında çekilip diğer ișlemler için bilgisayar ortamına aktarılmıştır. Her bir bandın molekül ağırlığı Total Lab 1D Manual R11.1, UK programı kullanılarak hesaplanmıș ve jel görüntüleri programa yüklendikten sonra bantlar piksel pozisyonlarına göre belirlenmiștir.

Küme analizi için veriler Phoretix 1D-Pro (Totallab, UK) programı kullanarak Jaccard'ın benzerlik katsayısı temeline dayanan unweighted pair-group metod using aricmetic averages (UPGMA) metoduyla hesaplanarak dendrogram olușturulmuştur.

\section{BULGULAR}

Çalıșmamızda, Sinop ilindeki balık satıcılarından bir kg olacak șekilde alınan toplam 44 adet hamsi ve zargana balık örneklerinden Vibrio spp. taraması yapılmıș ve toplam 12 örnekte izolasyon gerçekleștirilmiștir. Bakteri izole edilen balık örnekleri, toplandıkları zaman ve bakteri izolatlarına ait numara ve sembolleri Tablo 1'de gösterilmiștir.

İzolasyonu yapılan ve olası Vibrio spp. izolatlarının doğrulamalarının yapılabilmesi için morfolojik, fizyolojik ve biyokimyasal testler uygulanmıştır (Tablo 2). İzolatların tümünün katalaz, oksidaz, nitrat kullanımı, jelatinaz aktivite, sitrat ve $\% 6 \mathrm{NaCl}$ 'de gelișebilme testlerinin pozitif olduğu saptanmıștır. İzolatların $\% 58,3$ 'ü için indol pozitif, tümü için ise üreaz, $\mathrm{H}_{2} \mathrm{~S}$ ve Voges-Proskauer testlerinin negatif oldukları tespit edilmiştir. Ayrıca tüm izolatlar, glikozu fermente ederken, sakkarozu \%66,6'sının, laktozu \%75'inin, mannozu \%33,3'ünün ve arabinozu ise \%25'inin kullanabildiği görülmüștür (Tablo 2).

Tablo 1. Vibrio spp. izolatlarının numaraları/sembolleri izole edildikleri balık isimleri ve balıkların temin edildikleri tarihler

\begin{tabular}{|c|c|c|c|}
\hline \multicolumn{2}{|c|}{ Vibrio spp. İzolat } & \multirow{2}{*}{$\begin{array}{c}\text { Vibrio spp. } \\
\text { İzole Edilen } \\
\text { Balık İsmi }\end{array}$} & \multirow{2}{*}{$\begin{array}{c}\text { Balık Örneklerin } \\
\text { Alınma Tarihi }\end{array}$} \\
\hline Numarası & Sembolü & & \\
\hline 1 & $\mathrm{Z1}$ & Zargana & 14 Eylül 2014 \\
\hline 2 & $\mathrm{Z2}$ & Zargana & 17 Eylül 2014 \\
\hline 3 & $\mathrm{Z3}$ & Zargana & 4 Ekim 2014 \\
\hline 4 & Z4 & Zargana & 16 Ekim 2014 \\
\hline 5 & Z5 & Zargana & 26 Ekim 2014 \\
\hline 6 & Z6 & Zargana & 28 Ekim 2014 \\
\hline 7 & $\mathrm{H} 1$ & Hamsi & 21 Kasım 2014 \\
\hline 8 & $\mathrm{H} 2$ & Hamsi & 27 Kasım 2014 \\
\hline 9 & $\mathrm{H} 3$ & Hamsi & 6 Aralık 2014 \\
\hline 10 & $\mathrm{H} 4$ & Hamsi & 11 Aralık 2014 \\
\hline 11 & H5 & Hamsi & 28 Aralık 2014 \\
\hline 12 & H6 & Hamsi & 4 Ocak 2015 \\
\hline
\end{tabular}

Yapılan antibiyogram test sonuçlarına göre izolatların; seftazidime $\% 66,6$, gentamisine $\% 25$, tetrasikline $\% 16,6$, seftriazona $\% 91,6$, amikasine $\% 16,6$, ofloksine $\% 25$ ve penisilin G'ye $\% 58,3$ oranında direnç gösterdikleri saptanmıștır (Tablo 3). Ayrıca belirtilen kriterlere göre MARI değeri 0,2'den yüksek ise; aşırı antibiyotik vb. ilaçların kullanıldığı (yüksek risk) çevrelerden köken alan bakteriyel sușları, değerin 0,2'ye eșit veya daha düșük olması ilaç kullanımının nadir olduğu (düşük risk) çevresel örneklerden köken alan suşları göstermektedir. Çalıșmamızda, MARI değeri 0,41 olarak yüksek risk sınıfında bulunmuştur.

Plazmid profiline göre tüm izolatlarda 1-4 plazmid (1.590-27.000 bp aralığında) görülmüștür. İzolatların tümünde 19.400 bp'lik plazmid bulunmakta olup bu durum plazmid profillerine göre izolatlar arasında yüksek benzerlik olduğunu göstermiştir (Şekil 1). 
Tablo 2. Vibrio spp. izolatlarının numaraları/sembolleri, izole edildikleri balık isimleri ve balıkların temin edildiği tarihler

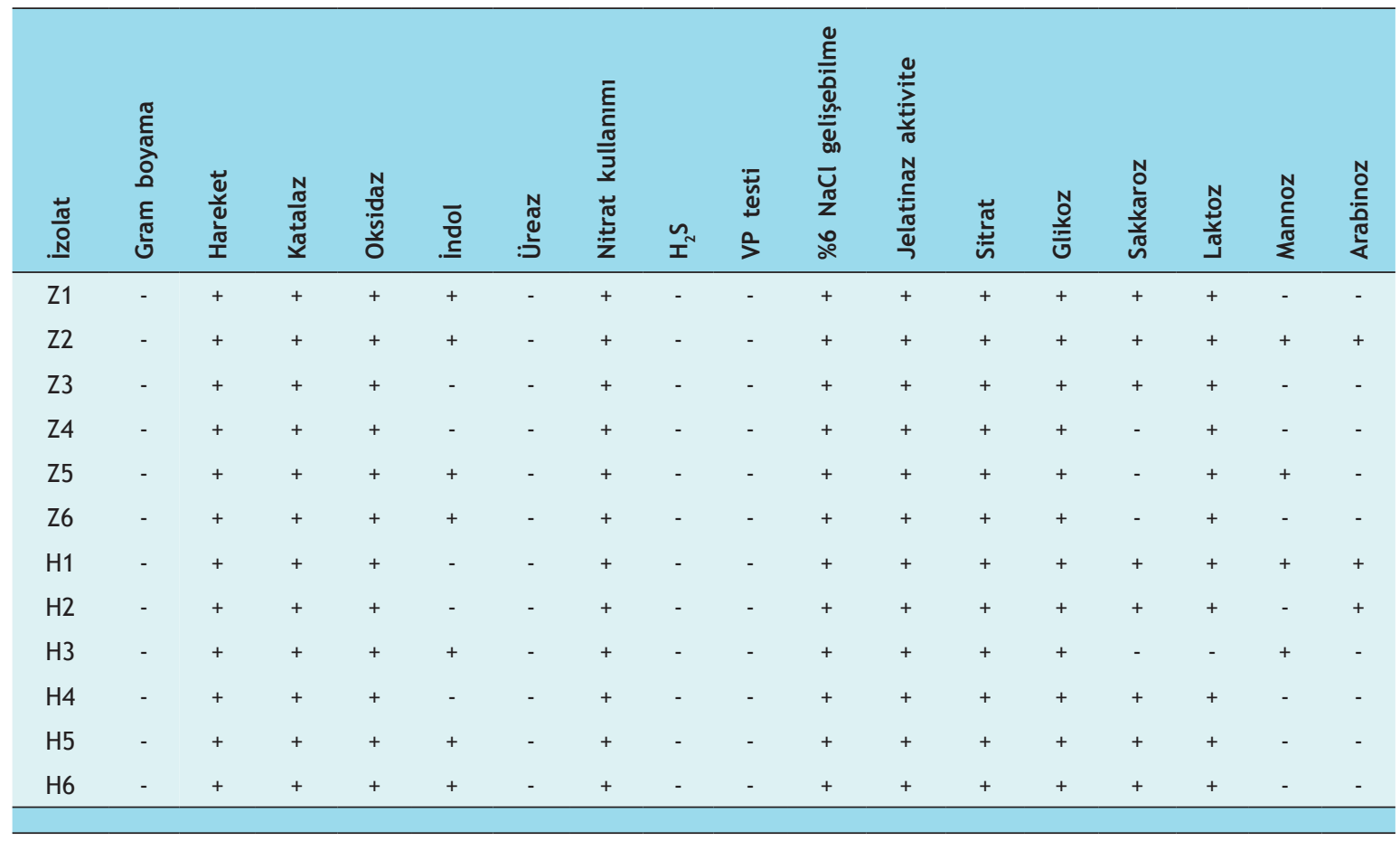

Tablo 3. Vibrio spp. izolatlarının antibiyogram sonuçları

\begin{tabular}{|c|c|c|c|c|c|c|c|c|}
\hline & & & $\begin{array}{l}\text { biyot } \\
(\mathrm{mm}\end{array}$ & $\begin{array}{l}\text { Disl } \\
\text { göre }\end{array}$ & $\begin{array}{l}\text { er ve } \\
\text { oiren }\end{array}$ & $\begin{array}{l}\text { Zon } \\
\text { Prof }\end{array}$ & $\begin{array}{l}\text { aplar } \\
\text { leri }\end{array}$ & \\
\hline & & $\mathbf{P}$ & Cro & Ak & Oft & $\mathrm{Te}$ & Gen & $\mathrm{Caz}$ \\
\hline 1 & $\mathrm{Z} 1$ & $\mathrm{R}$ & $\mathrm{R}$ & $\mathrm{S}$ & $\mathrm{S}$ & $S$ & $S$ & $\mathrm{~S}$ \\
\hline 2 & $\mathrm{Z2}$ & $\mathrm{S}$ & $\mathrm{R}$ & $S$ & 1 & I & $S$ & $\mathrm{R}$ \\
\hline 3 & Z3 & $\mathrm{R}$ & $\mathrm{R}$ & $S$ & $\mathrm{R}$ & $S$ & $S$ & $\mathrm{R}$ \\
\hline 4 & Z4 & $S$ & $\mathrm{R}$ & $S$ & $S$ & $\mathrm{R}$ & $S$ & I \\
\hline 5 & Z5 & $S$ & $\mathrm{R}$ & $\mathrm{R}$ & $S$ & $S$ & $\mathrm{R}$ & $\mathrm{R}$ \\
\hline 6 & Z6 & $\mathrm{R}$ & $\mathrm{R}$ & I & $S$ & $S$ & $\mathrm{R}$ & I \\
\hline 7 & $\mathrm{H} 1$ & $S$ & $S$ & $\mathrm{R}$ & $\mathrm{R}$ & 1 & $S$ & $\mathrm{R}$ \\
\hline 8 & $\mathrm{H} 2$ & $\mathrm{R}$ & $\mathrm{R}$ & $S$ & $\mathrm{R}$ & $\mathrm{R}$ & $S$ & $\mathrm{R}$ \\
\hline 9 & $\mathrm{H} 3$ & $\mathrm{R}$ & $R$ & $S$ & $S$ & 1 & $S$ & $R$ \\
\hline 10 & $\mathrm{H} 4$ & $\mathrm{R}$ & $\mathrm{R}$ & $S$ & $S$ & $S$ & $S$ & $\mathrm{R}$ \\
\hline 11 & $\mathrm{H} 5$ & $S$ & $\mathrm{R}$ & I & I & I & $S$ & $\mathrm{R}$ \\
\hline 12 & H6 & $\mathrm{R}$ & $\mathrm{R}$ & $S$ & $S$ & $S$ & $S$ & $S$ \\
\hline
\end{tabular}

R: Dirençli; S: Duyarlı; I: Orta derecede dirençli
Ayrıca, izolatlara ait toplam hücre protein profillerine dayalı oluşturulan dendrograma göre \%80 ve üzerinde iki gruba (A ve B) ayrıldığı, A grubunda 5 ve 6 numaralı zargana balık örneklerinden izole edilen suşların olduğu, B grubunun ise kendi içerisinde \%91 ve üzerinde benzerlik gösterdiği görülmüș ve bu gruba göre zargana ve hamsi balık örneklerinden izole edilen sușların birbirlerine yüksek oranda benzer oldukları tespit edilmiștir (Șekil 2).

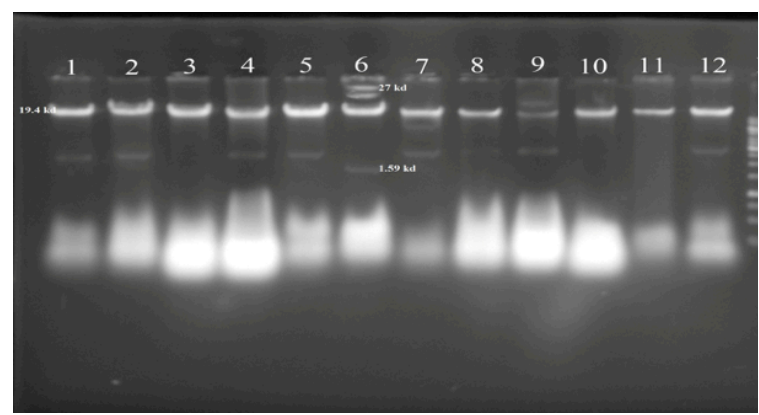

Şekil 1. Vibrio spp. izolatlarına ait plazmit DNA görünümü 


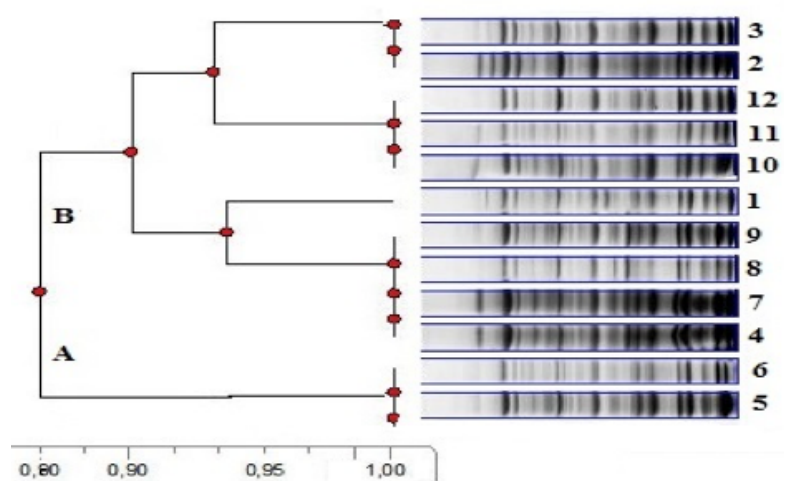

Şekil 2. Vibrio spp. izolatlarına ait SDS-PAGE toplam hücre protein profil dendrogramı

\section{TARTIŞMA}

Deniz ve nehir ağzı ortamlarında yașayan Vibrio türleri (özellikle $V$. vulnificus, $V$. parahaemolyticus ve $V$. cholerae) gastrointestinal hastalıklar ve bazı durumlarda septisemi nedenidirler. Sebep oldukları enfeksiyonlar ise önemli seviyelerde bakteri içeren kabuklu deniz ürünleri veya diğer deniz mahsullerinin uygunsuz işlenmesi, yetersiz pişirilmesi veya çiğ tüketilmesi ile artmaktadır (14).

Amos (15); Vibrio cinsi bakterilerde spor ve kapsül bulunmadığından dolayı farklı çevrelere yayılış gösteremediğini, bunun için habitatlarının sucul ortam olduğundan deniz ürünlerinde sıkça bulunduğunu belirtmiștir. Håstein ve ark. (16) yapmış oldukları çalıșmalarında ise Vibrio türlerinin sucul çevrelerde yaygın olarak bulunduğunu rapor etmişlerdir. Morris (17); epidemik V. cholerae sușlarının çevresel kaynaklardan insanlara ve deniz ürünlerine bulaștığını, $V$. vulnificus ve $V$. parahaemolyticus dâhil diğer Vibrio türleri ile $V$. cholerae'nin epidemik olmayan sușlarının deniz ürünlerinin çiğ ya da az pișmiş olarak tüketilmesi ile insanlarda enfeksiyonlara neden olduğunu belirtmiștir. Ayrıca, Japonya'da gıda yolu ile bulașan hastalıkların en az \%25'inin bu bakteriden kaynaklandığı, Hindistan'da ise ishalli hastaların $\% 3,5$ ile \%23,9'undan bu etkenin izole edildiği bildirilmiștir. Türkiye Halk Sağlığı Kurumu (18), Vibrio türlerinin çoğunun gıda kaynaklı olduğunu, sucul ortamlarda yașayıp ancak kirlenmiş su kaynakları aracılığıyla yayılabildiğini ve bu bakterilerin çoğunun hayatta kalabilmek için sıcak iklimlerde yayılıș gösterdiğini bildirmiștir. Korun (19); ülkemizde kültür balığı yetiștiriciliği yapan ișletmelerde özellikle levrek ve son zamanlarda gökkuşağı alabalığı işletmelerinde ciddi ekonomik kayıpların olduğunu ve bu kayıpların bakteriyel hastalıklara (Vibriozis, yersiniozis, furunkulozis ve bakteriyel hemorajik septisemi) benzer semptomlar meydana getirdiğini vurgulamıștır. Aydın ve Soyutemiz (20) yaptıkları çalıșmada; Bursa ilindeki satıcılardan topladıkları balık örneklerinde $V$. parahaemolyticus taraması yapmışlar ve hiçbirörnekte bu sușa rastlamadıklarını bildirmişlerdir. İnal ve ark. (21); 299 deniz balığında $V$. parahaemolyticus taraması yapmıșlar ve sadece bir örnekte tespit etmișlerdir. İnal ve ark. (22)'nın yaptıkları bașka bir çalıșmada ise Samsun-Sinop arasındaki kıyıda avlanan 53 balık örneğinde $V$. parahaemolyticus için 37 pozitif sonuç elde ettiklerini rapor etmișlerdir.

Manjusta ve ark. (23); farklı ortamlardan izole ettikleri Vibrio spp. izolatlarının 22 farklı antibiyotik ile çoklu antibiyotik dirençliliğini çalıșmışlar ve 119 Vibrio izolatının \%16,8'inin tüm antibiyotiklere duyarlı olduğunu, \%30,3'ünün üç antibiyotiğe, \%55,5'inin dört ile on antibiyotiğe, $\% 14,14$ 'ünün on antibiyotikten fazlasına dirençli olduğunu tüm izolatlardan \%54'ünün çoklu antibiyotik direncigösterdiğini saptamıșlardır. Rojas ve ark. (24); istiridye ve midye örneklerinden izole ettikleri $19 \mathrm{~V}$. parahaemolyticus suşunun içerisinde altı suşun en az iki antibiyotiğe dirençli olduğunu, ayrıca tüm suşların imipenem, nalidiksik asit ve seftazidime duyarlı olduklarını bildirmişlerdir. Marhual ve ark. (25); deniz ürünlerinden izole ettikleri altı Vibrio spp. suşunun (üç adet $V$. alginolyticus ve üç adet $V$. parahaemolyticus), 
birden fazla antibiyotiğe dirençli olduklarını ve bir ile üç arasında plazmid DNA içerdiklerini rapor etmișlerdir. Bu çalıșmalara paralel olarak elde ettiğimiz çalıșmamızın sonuçlarında da izole edilen 12 Vibrio spp. sușunun iki veya beș antibiyotiğe karșı çoklu direnç gösterdikleri ve bir ile dört plazmid DNA'ya sahip oldukları görülmüștür. Vibrio spp. izolatlarının test edilen antibiyotiklerin çoğuna karșı dirençli olduğu tespit edilmiș ve bu durumunda antibiyotik ve bazı diğer ilaç kalıntıları ile bulașı su kaynaklarından dolayı olabileceğini düșündürmüștür. Bu çalıșmamızda elde edilen 0,41 MARI değeri, bu durumu desteklemektedir.

Yoon ve ark. (26); 13 adet Vibrio türünün toplam hücre protein profiline göre tanımlanması üzerine yaptıkları çalıșmada, türlerin kendi aralarında ayrımlarında \%56 ve üzerinde benzerlik sağladığını böylece bu tekniğin Vibrio türlerini ayırmada tür altı düzeyde de hızlı, basit ve güvenilir olduğunu bildirmișlerdir. Benediktsdottir ve ark. (27); hastalıklı balık örneklerinden izole ettikleri $25 \mathrm{~V}$. viscosus ve $23 \mathrm{~V}$. wodanis sușlarının toplam hücre proteinlerinin benzerliklerine SDSPAGE yöntemi ile incelemișler ve sırasıyla \%92,8 ile $\% 88,3$ ve üzerinde benzerlik gösterdiklerini rapor etmișlerdir. Çalıșmamızdan elde ettiğimiz sonuçlara göre 12 Vibrio spp. izolatının kendi aralarında $\% 80$ ve üzerinde benzerliğe sahip olduğu ve bu çalıșmalarla paralellik gösterdiği görülmüștür.
Çalıșmamızda; Vibrio türlerinin diğer patojenik mikroorganizmalara nazaran tuzlu sularda ve bu sularda yetișen organizmalarda bulunması, bu ortamlara uyumlu olması ve ayrıca Sinop ilinde hem deniz suyunun rekreasyonel amaçlarla kullanılması hem de su mahsullerinin çok fazla tüketilmesi bu bakterinin olușturabileceği olası enfeksiyonları arttırması sonucunu çıkarabiliriz. Ayrıca, deniz ürünlerini tüketmeden önce iyi derecede pișirilmesi gerektiğini söyleyebiliriz.

Balık örneklerinde Vibrio türlerinin tespitinde kullanılan SDS-PAGE yöntemi ile toplam hücre protein profillerinin tür düzeyinde ayrımında hızl, güvenilir ve basit bir teknik olduğunu, buna rağmen tür altı ayrımda yetersiz kaldığı ve bunun için moleküler tekniklerin kullanılması gerektiğini önerebiliriz.

Çalıșmamızda elde ettiğimiz sonuçlara göre plazmid DNA profilleri ve çoklu antibiyotik dirençliliği arasında bir korelasyon bulunmamıștır. Tek bir plazmid DNA'ya sahip izolatlarda (3 ve 10 numaralı izolatlar) ikiden fazla antibiyotiğe dirençlilik saptanmıștır. Ayrıca antibiyotiklerin bilinçsizce kullanımı sonucu, denize atık olarak bırakılmasının insan sağıı̆ına etkilerini göz önünde bulundurarak bakterilerin antibiyotiklere karșı dirençliliklerinin arttığını ve bu durumla mücadele amaçlı sadece uygun antibiyotiklerin kullanılması ile çevreye bilinçsizce bırakılan ilaç türevi maddelerin önüne geçilmesi gerektiğini düșünmekteyiz.

\section{ÇIKAR ÇATIŞMASI}

Yazarlar herhangi bir çıkar çatıșması bildirmemektedir. 


\section{KAYNAKLAR}

1. Ustaçelebi Ş. Temel ve Klinik Mikrobiyoloji. Ankara: Güneș Kitabevi, 1999.

2. Uchiyama H. Distribution of Vibrio species isolated from aquatic environments with TCBS agar. Environ Health Preven Med, 2000; 4 (4): 199-204.

3. Boe B, Gjerde J. Fatty acid patterns in the classification of some representatives of the families Enterobacteriaceae and Vibrionaceae. J Gen Microbiol, 1980; 116 (1): 41-9.

4. Han F, Walker RD, Janes ME, Prinyawiwatkul W, $\mathrm{Ge}$ B. Antimicrobial susceptibilities of Vibrio parahaemolyticus and Vibrio vulnificus isolates from Louisiana Gulf and retail raw oysters. Appl Environ Microbiol, 2007; 73 (21): 7096-8.

5. Alavandi SV, Manoranjita V, Vijayan KK, Kalaimani N, Santiago TC. Phenotypic and molecular typing of V. harveyi isolates and their pathogenicity to tiger shrimp larvae. Let Appl Microbiol, 2006; 43 (5): 566-70.

6. Bej AK, Harold N, Vickery MCL, Brasher C, Jeffreys $A$, Jones DD, et al. Use of PCR to determine genomic diversity and distribution of siderophoremediated iron acquisition genes in clinical and environmental isolates of V. vulnificus, abstr. 97th General Meeting of the American Society for Microbiology. American Society for MicrobiologyWashington D.C., 1997.

7. Amorim A, Vasconcelos V. Dynamics of microcystins in the mussel Mytilus galloprovincialis. Toxicon, 1999; 37 (7): 1041-52.

8. Farmer III JJ, Hickman Brener FW. The Genera Vibrio and Photobacterium. In: Dworkin M, Falkow $\mathrm{S}$, Rosenberg E, Schleifer KH, Stackebrandt E, eds. The Prokaryotes: A Handbook on the Biology of Bacteria. 3rd edn. New York: Springer, 2006: 508-64.

9. Bauer AW, Kirby WM, Sherris JC, Turck M. Antibiotic susceptibility testing by a standardized single disc method. Am J Clin Pathol, 1966; 45 (4): 493-6.

10. Anonymous. National Committee for Clinical Laboratory Standards. Approved Standard M100-S20 performance standards for antimicrobial susceptibility testing; twentieth informational supplement. Wayne, PA: Clinical and Laboratory Standards Institute; 2010.
11. Sarter S, Nguyen HNK, Hung LT, Lazard J, Montet D. Antibiotic resistance in Gram-negative bacteria isolated from farmed catfish. Food Control, 2007; 18 (11): $1391-6$.

12. Laemmli UK. Cleavage of structural proteins during the assembly of the head of bacteriophage T4. Nature, 1970; 227: 680-5.

13. Sambrook J, Fritsch EF, Maniatis T. Molecular Clonning: a Laboratory Manual, 2nd ed. New York: Cold Spring Harbor Laboratory Press, 1989.

14. Panicker G, Call DR, Krug MJ, Bej AK. Detection of pathogenic Vibrio spp. in shellfish by using multiplex PCR and DNA microarrays. Appl Environ Microbiol, 2004; 70 (12): 7436-44.

15. Amos K. Procedures for the detection and identification of certain fish pathogens. 3rd. edn. Bethesda, Maryland: American Fisheries Society, 1985.

16. Håstein $\mathrm{T}$, Hjeltnes $\mathrm{B}$, Lillehaug $\mathrm{A}$, Skare JV, Berntssen M, Lundebye AK. Food safety hazards that occur during the production stage: challenges for fish farming and the fish industry. Rev Sci Tech off Int Epiz, 2006; 25: 607-25.

17. Morris JG. Cholera and other types of Vibriosis: a story of human pandemics and oysters on the half shell. Clin Infect Dis, 2003; 37 (2): 272-80.

18. Anonymous. Vibrio cholerae izolasyonu ve identifikasyonu standart laboratuvar prosedürleri. Ankara: THSK, Mikrobiyoloji Referans Laboratuvarları Daire Bașkanlığı, Ulusal Enterik Patojenler Referans Laboratuvarı, 2012.

19. Korun J. Kültürü yapılan çipuralarda (Sparus aurata L.) görülen Listonella anguillarum enfeksiyonu üzerine bir çalışma. Ege JFAS, 2006; 23 (Ek 1/2): 259-63.

20. Aydın A, Soyutemiz E. Bazı balık türlerinden ve kum midyelerinden (Venus gallina) Vibrio parahaemolyticus izolasyonu ve identifikasyonu. Turk J Vet Anim Sci, 2002; 26: 1249-53.

21. İnal T, Yurtyeri A, Ambarcı I. Untersuchungen über das Vorkommen von Vibrio parahaemolyticus im Jahre 1971 in der Türkei. Fleischwirtschaft, 1973; 53(9): 1299. 
22. Inal T, Yurteri A, Ambarcı I, Tolgay Z, Tezcan I. Untersuchungen über das vorkommen von Vibrio parahaemolyticus an der Schawarzmeerküste der Türkei. Alimenta, 1977; 16: 129-33.

23. Manjusha S, Sarita GB, Elyas KK, Chandrasekaran M. Multiple antibiotic resistances of Vibrio isolates from coastal and brackish water areas. Am J Biochem Biotech, 2005; 1(4): 201-6.

24. Rojas MVR, Matté MH, Dropa M, Silva ML, Matté GR. Characterization of Vibrio parahaemolyticus isolated from oysters and nussels in São Paulo, Brazil. Rev Inst Med Trop Sao Paulo, 2011; 53 (4): 201-5.
25. Marhual NP, Das BK, Samal SK. Characterization of Vibrio alginolyticus and Vibrio parahaemolyticus isolated from Penaeus monodon: antimicrobial resistance, plasmid profiles and random amplification of polymorphic DNA analysis. Afr J Microbiol Res, 2012; 6 (20): 4270-6.

26. Yoon LC, Ryu J, Oh SS, Hwang IG. Detection and identification of Vibrio species using whole-cell protein pattern analysis. J Microbiol Biotech, 2012; 22 (8): 1107-12.

27. Benediktsdóttir E, Verdonck L, Spröer C, Helgason $\mathrm{S}$, Swings J. Characterization of Vibrio viscosus and Vibrio wodanis isolated at different geographical locations: a proposal for reclassification of Vibrio viscosus as Moritella viscosa comb. nov. Int J Syst Evol Microbiol, 2000; 50 (2): 479-88. 


\title{
2013 yılında Muğla ili Marmaris ilçesinde görülen Staphylococcus aureus enterotoksin kaynaklı gıda zehirlenmesinin değerlendirilmesi
}

\author{
Evaluation of food poisoning of Staphylococcus aureus enterotoxin \\ source in 2013 in the Marmaris district of Muğla, Turkey
}

Celal TUTUŞ', Demet BÖREKÇi'1, Gürcan PARCIKLI'1, Fehminaz TEMEL'1, Mustafa Bahadır SUCAKLI'

\begin{abstract}
ÖZET
Amaç: Aynı yemek firması tarafından verilen öğle yemeği ve akșam yemeği sonrası iki okuldaki öğrenciler ile 17 ișyerindeki ișçilerden oluşan toplam 116 kiși; bulantı, kusma, karın ağrısı ve ishal şikâyetleri ile 23 Aralık 2013 tarihinde, Muğla İli Marmaris Devlet Hastanesi'ne bașvurmuștur. Bu çalıșma; zehirlenmenin bulaș yollarını ve olası kaynak ya da kaynakları belirlemek ve kontrol önlemlerini uygulamak için yapılmıștır.

Yöntemler: Şüpheli vaka olarak "23 Aralık 2013 tarihinde söz konusu 17 işyeri ile iki okulda bulunan ve bulantı, kusma, karın ağrısı, ishal, ateș semptomlarından en az biri görülen kiși” olarak tanımlanmıștır. Olası vaka ise şüpheli vakalardan "kusma veya ishal șikâyeti olan kișiler” olarak kabul edilmiștir. Kontroller, aynı okul/ișyerinde bulunan belirtilen semptomları olmayan kișiler arasından seçilmiștir. Çalıșmada, ișyerlerinde ve okullarda toplam 213 (100 vaka, 113 kontrol) kiși ile yüz yüze görüşülüp anket uygulanmıștır. Analizler 77 olası vaka, 100 şüpheli vaka ve 113 kontrol grubu üzerinden yapılmıștır. Gaita örnekleri, yemek üretim firmasının mutfak araç ve gereçlerinden sürüntü, gıda ve su örnekleri alınmıștır. Ayrıca gıda elleyicilerinden alınan örnekler Staphylococcus aureus açısından incelenmiștir.
\end{abstract}

\section{ABSTRACT}

Objective: On 23rd of December, 2013, 116 patients including students of two schools, and workers of 17 work places who consumed lunch and dinner from the same catering company, applied to Marmaris State Hospital, Muğla province suffering from nausea, vomiting, abdominal pain, and diarrhea. This study was conducted to identify the cause, and mode of transmission, and to implement control measures.

Methods: The suspected case was defined as "individuals working in 17 work places and two schools and having at least one of the following symptoms onset on 23 December 2013: nausea, vomiting, stomach ache, diarrhea, and fever". Probable case was accepted as "suspected case having vomiting or diarrhea". Controls were selected from the same school/workplace among persons who didn't have these symptoms. In the study, face to face interviews were conducted for 213 (100 cases, 113 controls) people. Seventy seven probable cases, 100 suspected cases and 113 controls were included in the analysis. Samples from stool, swabs of the kitchenwares and untensils, samples from food and water were taken. Moreover, samples from food handlers were tested for $S$. aureus. * Bu çalıșma; X, 17. Ulusal Halk Sağlığı Kongresi'nde (20-24 Ekim 2014, Edirne-TÜRKiYE ve European Scientific Conference on Applied Infectious Disease Epidemiology (5-7 Kasım 2014, Stockholm-İsveç) kongresinde poster bildirisi olarak sunulmuștur.

1 Türkiye Halk Sağlığı Kurumu, Erken Uyarı Cevap ve Saha Epidemiyolojisi Daire Başkanlı̆̆ı, ANKARA

\begin{tabular}{|c|c|c|}
\hline \multicolumn{3}{|c|}{$\begin{array}{l}\text { İletişim / Corresponding Author: Celal TUTUŞ } \\
\text { Türkiye Halk Sağlığı Kurumu, Erken Uyarı Cevap ve Sal }\end{array}$} \\
\hline Tel : +903125655000-2525 & E-posta / E-mail : drmct.02-98@hotmail.com & Kabul Tarihi / Accepted : 04.01.2016 \\
\hline
\end{tabular}

DOI ID : 10.5505/TurkHijyen.2016.79847

Tutuș C, Börekçi D, Parcıkı G, Temel F, Sucaklı MB. 2013 yılında Muğla ili Marmaris ilçesinde görülen Staphylococcus aureus enterotoksin kaynaklı gıda zehirlenmesinin değerlendirilmesi. Turk Hij Den Biyol Derg, 2016; 73(2): 131-8. 
Bulgular: Vakaların, 23 Aralı 2013 Pazartesi günü öğle yemeği yenmesinden sonra ortaya çıktığ saptanmıștır. Aynı gün verilen yemek menüsünde; tavuk döner, pilav, mantar çorbası, salata ve ayran olduğu belirlenmiștir. İlk vaka; Muğla İli Marmaris ilcçesi Merkez Devlet Hastanesi'ne aynı gün içinde saat 12:30'da bulantı, kusma șikayetleri ile başvurmuştur. Vakalarda en sık görülen semptomlar sırasıyla; bulantı, karın ağrısı, kusma, ishal ve yüksek ateștir. Atak hızı \%16 olarak belirlenmiștir. Zehirlenme eğrisi tek kaynaklı olduğunu göstermiștir. Vaka ve kontroller yaș ve cinsiyet açısından benzer bulunmuștur. Vakaların \%96 (74/77)'sı ve kontrollerin \%32'sinin (37/113) yemekte tavuk döner yediği saptanmıștır (TRR - tahmini rölatif risk): $50 \% 95$; Güven Aralığı: 14-171). Mantar çorbası ve salata kontrol TRR - tahmini rölatif risk): 50 \%95; GA-güven aralığı: 14171 edildiğinde $(37 / 113)$ ise vakalarda kontrollere göre tavuk döner yeme TRR 34 kat (TRR ayar - Ayarlı tahmini rölatif risk $=34, \% 95 \mathrm{GA}=8,8-129,7)$ bulunmuștur. il Gıda Kontrol Laboratuvarında değerlendirmesi yapılan tavuk dönerinde stafilokok enterotoksini tespit edilmiștir.

Sonuç: Marmaris ilcçesi'nde görülen zehirlenmeye tavuk dönerde saptana $S$. aureus enterotoksininin sebep olduğu görülmüștür. Araștırmada bulaş kaynağı gösterilememiștir. Yemek firması tarafından kontrol ve koruma önlemlerin alınması ve firma çalıșanlarına iyi hijyen uygulamaları konusunda eğitim verilmesi önerilmiștir.

Anahtar Kelimeler: Staphylococcus aureus, gida kaynaklı zehirlenme, vaka-kontrol çalıșması
Results: Cases started to increase after lunch on Monday at 23 December 2013. The menu of the company included chicken doner, rice, mushroom soup, salad and buttermilk. The first case attended Muğla, Marmaris District Public Hospital during the same day with nausea and vomiting complaints at $12: 30$. Most common symptoms seen in the cases, were nausea, abdominal pain, vomiting, diarrhea and high fever. The attack rate was determined as $16 \%$. The epidemic curve revealed a point source outbreak. Cases and controls had similar characteristics for age and sex. It was determined that $96 \%(74 / 77)$ of cases and $32 \%(37 / 113)$ of controls ate chicken doner (OR - odds ratio: $5095 \%$ $\mathrm{Cl}$ : 14-171). After controlling for mushroom soup and salad, odds of being ill was 34 (ORadj - adjusted odds ratio $=34,95 \% \mathrm{Cl}$-confidence interval $=8.8-129.7)$. In the analysis done by the Provincial Agriculture - Food Laboratory on the food samples S. aureus enterotoxin was identified in chicken doner sample.

Conclusion: It was found that the poisoning seen in the Marmaris district was caused by $S$. aureus enterotoxin in the chicken doner. In the research the source of contamination was not shown. Recommendations were given to the food company to implement control and protection measures; and to provide training on good hygiene practices for company workers.

Key Words: Staphylococcus aureus, food-borne poisoning, case-control study

\section{Giriș}

Gıda kaynaklı hastalıklar, toplumun her kesiminden ve her yaștaki bireyi etkileyen önemli bir toplum sağlığı sorunudur. Gıda kaynaklı enfeksiyonlar, sporadik vaka olarak görülebileceği gibi bulașı gıda kaynaklı, birden fazla kișiyi etkileyen zehirlenmeler şeklinde de görülebilir (1). Yapılan araştırmalarda gıda kaynaklı enfeksiyonların yaklaşık üçte birinin bakteriyel etkenli olduğu saptanmıștır. Gıda kaynaklı hastalıkların çoğu bakterilerin ürettiği toksinlerden veya bakteri miktarından kaynaklanır. Bazı bakteriler; gerekli su, besin, sıcaklık ve zaman koșulları oluştuğunda milyonlarca üreyebilirler. $\mathrm{Ne}$ kadar çok bakteri varsa, enfeksiyon ve hastalık riski de o kadar yüksektir. Gelișen hastalıkların şiddeti, hafif karın ağrısından gıda kaynaklı zehirlenmeye kadar değișen geniş bir spektrum șeklinde görülmektedir. 
Hastalıkların olușumunda en önemli etken, gıdaların hijyenik olmayan koșullarda muhafaza edilmesi ve hazırlamasında yapılan hatalardır (2).

Endüstrileșme ile beraber hazır yemek ile beslenmeye karșı eğilimin son yıllarda artıș gösterdiği görülmektedir. ABD, İngiltere ve Hollanda'da elde edilen istatistiksel verilere göre gıda kaynakl hastalıkların \%70'inden fazlası yemek veya servis hizmeti veren sektörlerle ilișkilendirilmektedir (3).

Amerika Birleșik Devletleri Hastalık Kontrol Merkezi (CDC)'nin 2005 yılı raporuda 205 gida kaynaklı hastalık salgını rapor edilmiștir. ABD'de her yıl 325.000'i hastanede yatmayı gerektiren ve 5.000'i ölüm ile sonuçlanan yaklașık 76 milyon vakanın olduğu tahmin edilmektedir (4). Bu durum her yıl dört Amerikalıdan birinin bu enfeksiyonlar ile karșılaștığını göstermektedir. İngiltere'de sadece 2000 yılında 1.3 milyondan fazla gıda kaynaklı intestinal enfeksiyon bildirilmiștir (5).

Son zamanlarda gıda kaynaklı salgınlarda en çok Staphylococcus aureus ve Clostridium perfringens etken olarak gözlenmektedir. Günümüzde, gıda kaynaklı enfeksiyonlarda 27 temel patojen mevcuttur. En önemlileri Campylobacter, Salmonella spp., Clostridium türleri, S. aureus, Escherichia coli 0157:H7, Bacillus cereus ve Listeria monocytogenes'tir. Bununla birlikte bu patojenler gıda kaynaklı enfeksiyonların toplam tahmini sayısının sadece \%19'unu olușturmaktadırlar $(6,7)$.

Stafilokokkal gıda zehirlenmeleri ABD'de en sık görülen ikinci sıradaki gıda kaynaklı zehirlenme nedenidir ve gıda kaynaklı salgınların \%14-20'sini olușturmaktadır (8).

Ülkemizde yapılan bir çalıșmada, Marmara bölgesinde perakende olarak satılan 1070 gıda örneğinde inceleme yapılmıștır. Patojen etken saptanan 147 örneğin 92 (\%62,6)'sinin stafilokokal toksinler ile enfekte olduğu tespit edilmiștir (9). $\mathrm{Bu}$ da tüm dünyada olduğu gibi ülkemizde de stafilokokal gıda zehirlenme riskinin yüksek olduğunu göstermektedir.
Bu çalıșma, Marmaris ilçesinde 23 Aralık 2013 tarihinde bașlayan bulantı, kusma ve ishal șikayetleri ile seyreden zehirlenmenin bulaș yollarını ve olası kaynak ya da kaynaklarını belirlemek ve kontrol önlemlerini uygulamak için yapılmıștır.

\section{GEREÇ VE YÖNTEM}

Bu çalıșmada, etkilenen kiși sayısının fazlalığı ve olayın toplum sağlığını etkileme riski tașıması nedeniyle Türkiye Halk Sağlığı Kurumu (THSK), Erken Uyarı Cevap ve Saha Epidemiyolojsi Daire Bașkanlığı (EUCSE DB)'nca konuyu inceleme kararı alınmıștır. EUCSE Daire Başkanlığı'ndan görevlendirilen personel ile Muğla Halk Sağıığı Müdürlüğü personeli tarafından 05 Ocak 2014 ile 11 Ocak 2014 tarihleri arasında Muğla ili Marmaris ilçesinde vakaların görüldüğü 17 ișyerinde ve iki okulda, iș yeri çalıșanlarının ve öğrencilerin tümüne ulașma güçlüğü nedeni ile vakakontrol çalıșması yapılmıștır. Şüpheli ve olası olmak üzere iki vaka tanımı oluşturulmuştur.

Şüpheli vaka; yemek firmasının dağıtım yaptığı 17 işyeri ve iki okulda; bulantı, kusma, karın ağrısı, ishal veya ateș șikâyetlerinden en az birine sahip olan kișiler, olası vaka ise șüpheli vakalar arsından kusma veya ishal șikâyetleri olan kișiler alınmıștır. Kontroller, aynı tarihte iș yerleri ve okullarda bulunan ve herhangi bir rahatsızlığı bulunmayan kișilerden seçilmiștir.

Anket uygulamasının bașında en fazla vakanın görüldüğü okul bașta olmak üzere, öğrenci/çalıșan sayısı yeterli olan okul/ișyerlerinde kiși listeleri alınmış, hastaneye başvuranlar çıkarılarak, kalan öğrenci/çalıșanlar arasından rastgele yöntemle kișiler seçilmiștir. Her ișletmede vaka sayısı kadar kontrol bulunamadığından ve vakalar bazı ișletmelerde kontrol sayısından daha fazla olduğundan kontroller ișletme bazında alınmamış, bütün ișletmelerden rastgele sayılar tablosu kullanılarak seçilmiștir. Çalıșmada, işyerlerinde ve okullarda 213 (100 vaka, 113 kontrol) kiși ile yüz yüze görüșülüp anket yapılmıștır. 77 olas vaka ve 113 kontrol ile ileri analizler yapılmıștır. Veri 
analizlerinde Excel ve Epilnfo paket programları kullanılmıștır. Verilerin değerlendirilmesinde; yüzde dağııımları, atak hızı, olası risk faktörlerini değerlendirmek için \%95 GA, TRR ve ayarlanmış TRR (lojistik regresyon) kullanılmıştır. İstatistiksel anlamlılık sınırı \%5 kabul edilmiștir.

Vakalardan alınan gaita örnekleri incelenmek üzere Marmaris ilcçe Devlet Hastanesi Laboratuvarına, gıda ve su numuneleri Muğla il Gıda Kontrol Laboratuvarı ve Halk Sağlığı Laboratuvarına gönderilmiștir.

\section{BULGULAR}

Muğla Halk Sağlığı Müdürlüğü tarafından 24.12.2013 tarihinde, Türkiye Halk Sağlığı Kurumu (THSK) Erken Uyarı-Cevap ve Saha Epidemiyolojisi Daire Bașkanlığına Marmaris İlçesi'nde 23.12.2013 tarihinde öğle ve akșam yemeği sonrası Devlet Hastanesi Acil Servisine (116 kiși), diğer hastane ve poliklinikler ile toplam 136 kișinin karın ağrısı, bulantı, kusma ve ishal șikâyetlerinden biri veya birkaçıyla bașvuran kișilerin beșinin yatıșının yapıldığı, büyük bir çoğunluğunun da birkaç saatlik gözlem ile taburcu edildiği uyarısı bildirilmiștir.
İșyeri ve okullarda, 23.12.2013 Pazartesi günü öğle yemeğinden sonra vakalar ortaya çıkmaya bașlamıștır. Olası vaka tanımına göre 77 vakanın \%66'sı erkek, \%34'ü kadındır. Vakaların yaș ortalaması $29,3 \pm 9,37$ olarak bulunmuştur.

$\mathrm{Bu}$ çalıșmada; yemek dağıtımı yapılan iș yerleri ve okullarda acile başvuran kiși sayısına göre hesaplanan kaba atak hızı \%16 bulunmuștur. Başvuranlarda en fazla görülen șikâyetlerin bulantı ve karın ağrısı olduğu tespit edilmiștir. Ayrıca kusma, ishal ve yüksek ateș de görülmüștür (Şekil 1).

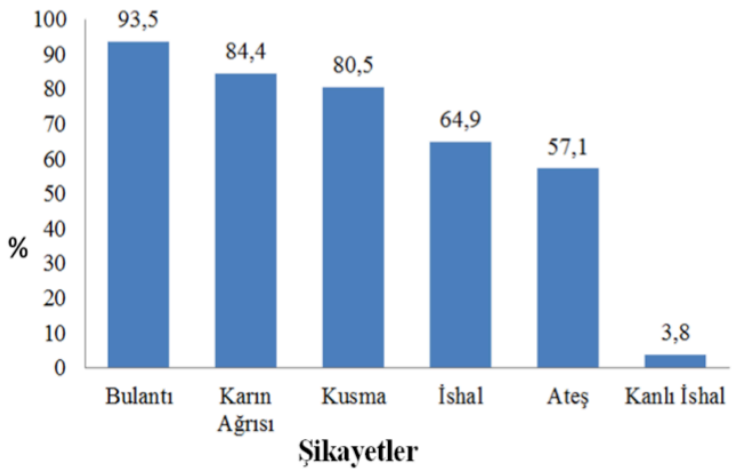

Şekil 1. Gıda zehirlenmesi ile başvuranlarda en fazla görülen șikayetlerin yüzde dağılımları

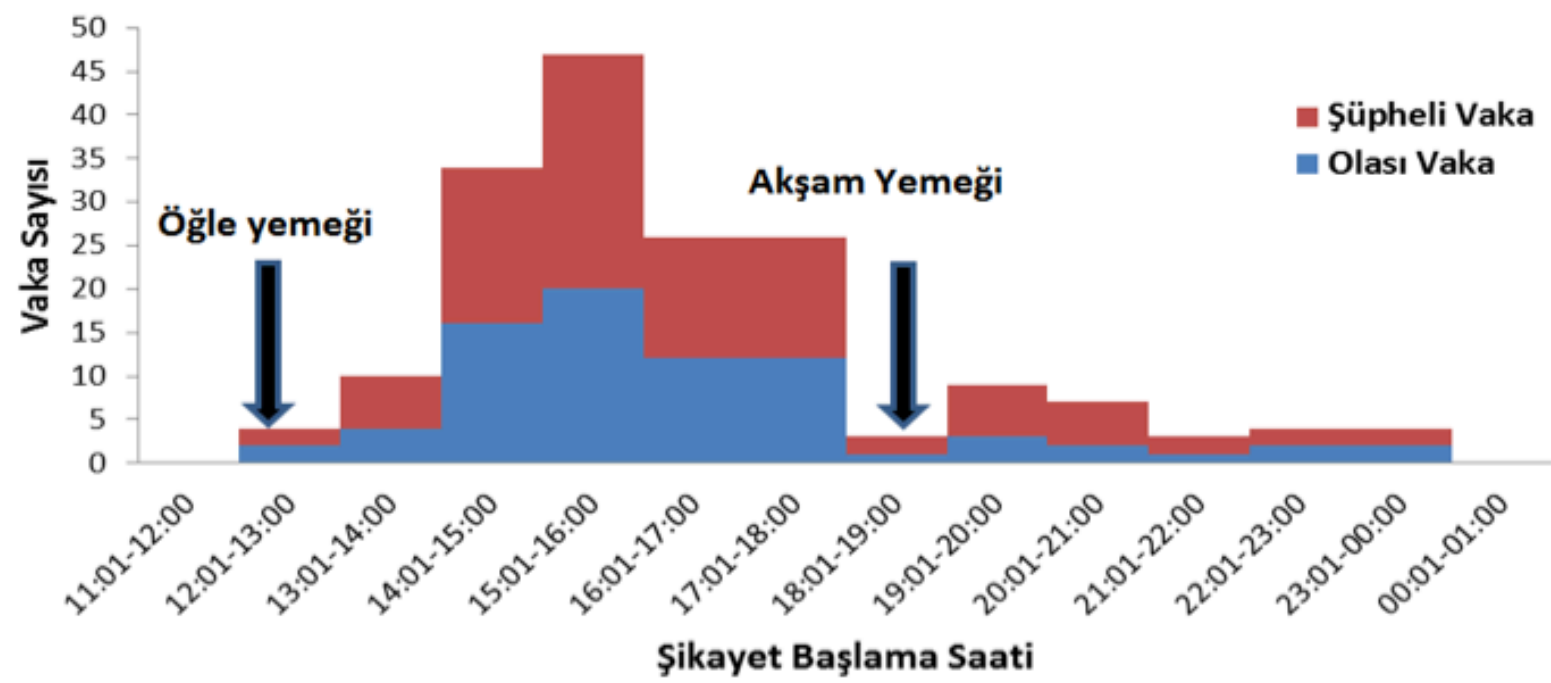

Şekil 2. Şikâyetlerin bașlama saatlerine göre dağııımı 
Şikâyetlerin bașlama zamanına göre çizilen zehirlenme eğrisinde şüpheli ve olası vakalara ait şikâyetlerin öğle ve akșam yemeklerinden sonra başlamış olduğu ve tepe noktalarının aynı zaman diliminde olduğu saptanmıștır. Zehirlenmenin tek kaynaklı etken özelliği gösterdiği belirlenmiștir (Şekil 2).

Zehirlenmenin inkübasyon süresinin $4.04 \pm 2.15$ saat $($ Ortanca $=3.30-$ En kısa $=0.5-$ En uzun $=11.20)$ olduğu bulunmuștur. Bu süre, zehirlenmeye neden olduğu düşünülen Staphylococcus aureus ile uyumlu görülmüștür.
Zehirlenmeye yol açan yemekleri tespit etmek için olası vakaların yemek menüsünde yer alan sebzeli tavuk döner, pilav, mantar çorbası, salata ve ayran yeme-içme durumları da değerlendirilmiştir (Tablo 1).

İlk analizlerde tavuk döner, mantar çorbası ve salatanın zehirlenme ile ilișkili olduğu saptanmıștır. Ancak mantar çorbası ve salata kontrol edildiğinde vakalarda kontrollere göre zehirlenme tahmini rölatif riski 34 kat $(8,8-129,7)$ bulunmuștur (Tablo 1).

Gaita kültürlerinde Salmonella spp. ve Shigella spp. açısından yapılan inceleme sonuçları negatif bulunmuștur (Tablo 2).

Tablo 1. Vaka ve kontrollerde gıdalara göre olası risk faktörleri

\begin{tabular}{|c|c|c|c|c|c|c|}
\hline \multirow{2}{*}{ Gida } & \multicolumn{2}{|c|}{ Vaka } & \multicolumn{2}{|c|}{ Kontrol } & \multirow{2}{*}{$\begin{array}{c}\text { TRR } \\
\text { (\%95 GA) }\end{array}$} & \multirow{2}{*}{$\begin{array}{c}\text { Ayarlı TRR } \\
\text { (\%95 GA) }\end{array}$} \\
\hline & Sayı & $\%$ & Sayı & $\%$ & & \\
\hline Tavuk döner & 74 & 96,0 & 37 & 32,1 & $50(14-171)$ & $33,9(8,8-129,7)$ \\
\hline Mantar çorbası & 58 & 75,0 & 32 & 28,5 & $7,6(3,9-15)$ & $2,3(1,05-5,4)$ \\
\hline Salata & 59 & 76,6 & 44 & 38,9 & $5,09(2,6-9,9)$ & $0,9(0,3-2,4)$ \\
\hline Ayran & 15 & 19,5 & 12 & 10,6 & $2,02(0,8-4,7)$ & \\
\hline
\end{tabular}

Tablo 2. Klinik ve klinik dıșı örneklerde yapılan analizlerin sonuçları

\begin{tabular}{|c|c|c|c|c|}
\hline Örnek & $\begin{array}{l}\text { Alınan } \\
\text { Örnek } \\
\text { Sayısı }\end{array}$ & $\begin{array}{l}\text { Kullanılan } \\
\text { Yöntem }\end{array}$ & Yapılan Mikrobiyolojik Analizler & Sonuç \\
\hline \multicolumn{5}{|l|}{ Klinik Örnekler } \\
\hline Gaita & 13 & Kültür & $\begin{array}{l}\text { Salmonella spp., Shigella spp., parazit yumurtası, kist } \\
\text { ve trofozoid }\end{array}$ & Negatif \\
\hline Kusmuk & 2 & Kültür & Salmonella spp. (VIDAS), Shigella spp. & Negatif \\
\hline \multicolumn{5}{|l|}{ Gıda Örnekleri } \\
\hline Tavuk döner & 2 & VIDAS & Stafilokokal enterotoksin, Bacillus cereus, Salmonella spp. & Pozitif \\
\hline Mantar çorbası & 2 & VIDAS & Stafilokokal enterotoksin, B. cereus, Salmonella spp.) & Negatif \\
\hline Salata & 1 & VIDAS & E.coli Stafilokokalenterotoksin, Salmonella spp. & Negatif \\
\hline Ayran & 1 & VIDAS & Listeria monocytogenes $E$. coli & Negatif \\
\hline $\begin{array}{l}\text { Mutfak Arac Örnekleri } \\
\text { (Kepçe, Tezgah, Buzdolabı } \\
\text { Rafları, Kıyma Makinesi vb.) }\end{array}$ & 19 & Kültür & E. coli, maya hücreleri, alfa hemolitik streptokoklar & Negatif \\
\hline$\frac{\text { Su Örnekleri }}{\text { Şebeke suyu }}$ & 1500 & $\begin{array}{l}\text { Membran } \\
\text { filtrasyon }\end{array}$ & Mikrobiyolojik Kontrol İzlemesi & Uygun \\
\hline
\end{tabular}


ilçenin su ihtiyacını sağlayan şebeke suyu ile ilgili yapılan mikrobiyolojik kontrol izleme analizleri olarak Clostridium perfringes (sporlar dahil), E. coli, koliform bakteri ile ağır metal (amonyum, demir) ve iletkenlik, $\mathrm{pH}$, koku, renk ve tat incelemesi sonucunda, su örnekleri ilgili yönetmeliğe uygun bulunmuştur.

Gıda Tarım ve Hayvancılık Bakanlığı Laboratuvarında yapılan tavuk döner örneğinde stafilokok enterotoksini tespit edilmiștir.

\section{TARTIŞMA}

Gıda kaynaklı hastalıklar (GKH) genel anlamda patojenik mikroorganizmalar, mikrobiyal toksinler ile bulașı olmuș gıdaların yenmesi ile olușan ve daha çok gastrointestinal semptomlarla seyreden klinik tablolardır $(7,10)$. GKH'ler sporadik olabileceği gibi salgınlar halinde de görülebilmektedir. Bazen küçük çocuklar ve yașlılarda ölümler (genel halk için \% 0,03) nadir olmakla birlikte görülmektedir (6).

Günümüzde, gıda kaynaklarının belli merkezlerden sağlanması ve bu gıdaların farklı bölgelere dağıtılması salgın yaygınlığını arttırmaktadır (11). Bu çalıșmada, zehirlenmeye neden olan ana gida maddesi olan tavuk dönerin üretim yeri ile ișlenip servis edilme merkezinin farklı illerde olması, gerekli incelemeler için izinlerin alınamaması nedeni ile işletmeler arasında geriye dönük gıda kontrol çalıșması yapılamamıștır.

Stafilokokal gıda zehirlenmesi hızla gelișen, şiddetli ve bol kusma, ishalli veya ishalsiz abdominal kramp ile karakterize edilmektedir (7). Çalıșmamızda; vakaların bulantı, kusma, karın ağrısı, ishal ve ateș gibi șikâyetlerinin olması $S$. aureus enfeksiyonunun klinik özellikleri ile uyumludur. İnkübasyon süresi 2-6 saat arasında değișmektedir. Bu süre stafilokokal gıda zehirlenmelerinde görülen inkübasyon süresi (30 dakika-8 saat) ile uyum göstermektedir (6).

Gıda analizinde de tavuk döner örneğinde $S$. aureus enterotoksininin tespit edilmesi tavuk döner kaynaklı bir S. aureus gıda zehirlenmesi olduğunu göstermiștir. Mantar çorbasında da riskin yüksek bulunması yemekler arasında bir çapraz bulașın olabileceğini düşündürmüștür.

Stafilokokal gida zehirlenmesi kendi kendini sınırlandıran bir hastalık olsa da hastaların yaklaşık \%10'u şikâyetlerinden dolayı acil servise bașvurmaktadır (12). Çalıșmamızda da gida zehirlenmesi șikayetleriyle kișiler (\%74) hastaneye başvurmuştur. Bunun nedeni bu intoksikasyonun işyerlerinde görülmesini düșündürmüștür. İşyeri, okul gibi toplu yemek yenen yerlerde bu tür gida kaynaklı zehirlenmelerde genellikle kişilerde semptomlar görüldükçe hastane bașvuruları da artmaktadır.

Birçok gida maddesi, S. aureus üremesi için uygun ortam olușturmaktadır. Sıklıkla süt, krema, kremalı pastalar, tereyağı, jambon, sosis, konserve et, salatalar, pișmiş yemekler, sandviç dolguları bu zehirlenmelerde rol oynamaktadır. Ingiltere'de yapılan bir çalıșmada; 1969 - 1990 arasında görülen salgınların \%53'ü bașta jambon olmak üzere etli yemeklere, \%22'si kümes hayvanları ile ilgili yemeklere, \%8'si süt ürünlerine, \%7'si balık ve kabuklu deniz hayvanlarına ve \%3,5'i yumurtaya bağlı olduğu görülmüștür (13). Çalıșmamızda da beklendiği gibi tavuk döneri kaynaklı bir enfeksiyon olduğu ortaya çıkmıștır.

Gıda zehirlenmelerinde, gıdanın hazırlanmasında görev alan personel bulașta önemli bir rol oynamaktadır. Stafilokokal gida zehirlenmelerinin \%25'inde elle ișleme așamasında bulaș olmaktadır. Sağlıklı kişilerin \%20-50'sinin cildinde, burnunda, boğazında veya enfekte cilt lezyonlarında $S$. aureus tașıdığı bilinmektedir. Organizma gözenekler ve kıl foliküllerinde gizlendiğinden ciltten uzaklaștırılması oldukça zordur. Nemli ellerle yüzeylere ve yiyeceklere bulașması mümkündür. S. aureus tașıyıcılarının düzenli olarak test yapılarak tespit edilmesine çalıșmak sürekli uygulanabilir bir durum değildir. Bu nedenle, genel olarak yiyeceklere çıplak elle dokunmaktan kaçınılması gerekmektedir (13). Çalışmamızdaki zehirlenme ile ilgili gözlemlerde; gıda elleyicilerinin eldivenle çalıștığı görülmüștür. Ayrıca laboratuvar 
incelemelerinde gerek gıda elleyicilerinden alınan örneklerde, gerekse mutfak araç ve gereçlerinden alınan sürüntü örneklerinde herhangi bir bulaş etkeniyle karşılaşılmamıștır. Yemeklerin hazırlandığı ve servis edildiği ortamın hijyeni de bulașta önemli bir faktör olarak rol oynamaktadır. Bu ortamın geçmiște yapılan düzenli kontrollerini incelediğimizde ise hijyen konusunda herhangi bir problem yaşamadığ kayıtlardan saptanmıştır. Bu nedenle, bulaşın personel ve ortamdan kaynaklanmadığı, bașka bir așamada gerçekleștiği düșünülmüștür.

\section{SONUÇ}

Laboratuvar sonuçları ve epidemiyolojik analizler, yașanan gida zehirlenmesine $S$. aureus enterotoksini bulașmıș tavuk dönerin neden olduğunu göstermiștir. Tavuk dönerin geriye dönük incelemesi yapılmış ve bu gıdanın bir firma tarafından satıldığı öğrenilmiștir. Ancak yemek firması tarafından kullanılan tavuk dönerin imalat yeri ile iletişim sağlanamamış ve incelenmesi için izin alınmamıştır. Bu nedenle, $S$. aureus bulaş yolunun ne șekilde olduğu tam olarak belirlenememiștir.
Gıda kökenli hastalık risklerini önemli ölçüde azaltmak ve toplum sağlığını korumak açısından Dünya Sağlık Örğütü tarafından "güvenli tüketim için işlenmiş gıdaların seçilmesi, pişirilecek gidalarda pişirme ișleminin tam ve kusursuz uygulanması, pișirme sonrası gıdaların bekletilmeden tüketilmesi, pișirilmiş gıdaların korunmasına özen gösterilmesi, gıdaların yeniden ısıtılmasının tam ve kusursuz uygulanması, çiğ ve pișmiş gıdaların birbiriyle temasından sakınılması, el temizliğinin ihmal edilmemesi, mutfaktaki yüzeylerin temiz tutulması, gıdaların kemirgen ve hașerelerden korunması ve temiz su kullanılması olarak "Altın Kuralları" tanımlamıștır. Bu önlemlerin toplu yemek üretim firmaları ve tüketiciler tarafından uygulanması için Gıda Tarım ve Hayvancılık Bakanlığı ile Sağlık Bakanlığı tarafından önerilerde bulunulmalıdır (14).

Gıda kaynaklı hastalıklarda kaynağın belirlenmesi ve bulaș zincirinin tespiti amacıyla Gıda Tarım ve Hayvancılık Bakanlığı ile Sağlık Bakanlığı'nın zamanında ve ortak hareket etmesi gerekmektedir. Bu nedenle, yürürlükte bulunan yasal düzenlenmenin uygulanabilirliğinin de artırılması gerekmektedir.

\section{TEȘEKKÜR}

Bu çalıșma, Bulașıcı Hastalıkların Sürveyansının Güçlendirilmesi Avrupa Birliği Projesi (TR0802.16-AB Fonu) ve T.C. Sağlık Bakanlığı Türkiye Halk Sağlığı Kurumu (THSK)'nun maddi desteği ile yapılmıştır.

Çalıșmadaki katkılarından dolayı, THSK Bulașıcı Hastalıklar Kontrol Programları Bașkan Yardımcılığına, THSK Mikrobiyoloji Referans Laboratuvarı çalıșanlarına, Muğla Halk Sağlığı Müdürlüğü, Muğla il Gıda Kontrol Laboratuvarı ve Muğla Halk Sağlığı Laboratuvarı çalıșanlarına teșekkür ederiz.

\section{ÇIKAR ÇATIŞMASI}

Yazarlar herhangi bir çıkar çatıșması bildirmemektedir. 


\section{KAYNAKLAR}

1. Özen NS, Tuğlu Ataman Ş, Seyman D, Akdağ $\mathrm{H}$, Emek M. Antalya ili gıda çalıșanlarında nazal Staphylococcus aureus taşıyıcılığının ve MRSA oranlarının üç farklı yöntem kullanılarak incelenmesi. Turk Hij Den Biyol Derg, 2013; 70 (2): 51-8.

2. Dorman V, Aslan S, Ceylan A, Nacar Küçük S, Günel A, Sarı H, et al. Aynı fabrikadan yemek alan iki inşaat firması ișçilerinde meydana gelen toplu besin zehirlenmesi. Dicle Tıp Derg, 2010; 37 (3): 248-53.

3. Şenses-Ergül Ş, Sarı H, Ertaș S, Berberoğlu U, Cesaretli Y, Irmak H. Tüketime sunulan çeșitli hazır yemek ürünlerinin mikrobiyolojik kalitesinin belirlenmesi. Turk Hij Den Biyol Derg, 2015; 72 (3): 199-20.

4. Ayçiçek H, Aktan HT. Gıda kaynaklı salgınlarda sorușturma ilkeleri. Turk Hij Den Biyol Derg, 2003; 60 (3): 95-9.

5. Heymann D. Control of Communicable Diseases Manual. 19th ed. American Public Health Association. Washington DC. United Book Press Inc., Baltimore MD., 2008.

6. Danielsson-Tham ML. Staphylococcal food poisoning. In: Tham W, Danielsson-Tham ML, eds. Food Associated Pathogens. Boca Raton. CRC Press, 2013: 250-68.

7. Kadariya J, Smith TC, Thapaliya D. Staphylococcus aureus and staphylococcal food-borne disease: An ongoing challenge in public health. BioMed Res Int, 2014; 1-9.
8. Lima GC, Loiko MR, Casarin LS, Tondo EC. Assessing the epidemiological data of Staphylococcus aureus food poisoning occurred in the State of Rio Grande do Sul, Southern Brazil. Braz J Microbiol, 2013; 44 (3): 759-63.

9. Aydin A, Sudagidan M, Muratoglu K. Prevalence of staphylococcal enterotoxins, toxin genes and genetic-relatedness of foodborne Staphylococcus aureus strains isolated in the Marmara Region of Turkey. Int J Food Microbiol, 2011; 148 (2): 99-106.

10. Adams M, Motarjemi Y. Basic food safety for health workers. Geneva: World Health Organization, 1999.

11. Kartal ED, Gıda kaynaklı infeksiyonlar. I. Türkiye Zoonotik Hastalıklar Sempozyumu. 14-15 Kasım, Ankara, Türkiye. 2006.

12. Holmberg, SD, Blake PA. Staphylococcal food poisoning in the United States: New facts and old misconceptions. JAMA, 1984; 251 (4): 487-9.

13. Loir LY, Florence B, Gautier M. Staphylococcus aureus and food poisoning. Genet Mol Res, 2003; 2 (1): 63-76.

14. Özkaya Durlu F, Cömert M. Gıda zehirlenmelerinde etken faktörler. Turk Hij Den Biyol Derg, 2008; 65 (3): $149-58$ 


\section{İzmir'de sağlık kurumlarına yemek üretim ve dağıtım hizmeti veren bir firmada çalışanların gıda hijyeni ile ilgili bilgi ve davranışları}

\section{The knowledge and behaviour of workers on food hygiene who worked in a company providing catering and distribution service to the health institutions in Izmir}

Şadan KÖKSAL ${ }^{1}, \quad$ Ahmet SOYSAL ${ }^{2}, \quad$ Gül ERGÖR ${ }^{2}$, Gülşah KANER

\section{ÖZET}

Amaç: Bu çalıșmanın amacı İzmir'de bir yemek firmasında çalıșanların gıda hijyeni ve kișisel hijyen ile ilgili bilgi ve davranıșlarını araștırmak, bilgi ve davranıșlarına etki eden etmenleri belirlemektir.

Yöntemler: Kesitsel tipte planlanan çalıșma, ISO 22000 Gıda Güvenliği Yönetim Sistemine sahip bir yemek firmasının merkez mutfağında ve hizmet verdiği hastane mutfaklarında yürütülmüş, yemek firmasındaki tüm çalışanların (n:73) çalıșmaya alınması planlanmış, ancak çalıșma 59 kiși ile tamamlanmıștır. Çalıșma verilerinin toplanması anket ve gözlem yapılarak araștırmacı tarafından gerçekleștirilmiștir. Gözlem yalnızca mutfak çalıșanlarında yapılmıștır. Gıda hijyeni ile ilgili bilgileri puanlandırılarak yeterli ve yetersiz olarak, gıda hijyenine yönelik gözlenen davranışları ise uygun ve uygun değil olarak değerlendirilmiștir. Veriler, SPSS 15.0 paket programı ile analiz edilmiş, sosyodemografik özellikler ve çalıșma süresinin hijyen bilgi düzeyi ve davranıș durumu ile karșılaștırılmasında kikare testi kullanılmıștır. Elde edilen $p$ değeri 0,05 'ten küçükse fark anlamlı kabul edilmiștir.

Bulgular: Çalıșanların yaș ortalamasının $35,4 \pm 7,6$ olduğu ve $\% 86,4$ 'ünün mutfak çalışanı, $\% 13,6$ 'sının her zaman mutfakta bulunmayan gida mühendisi, gıda teknisyeni, sekreter ve șoför olduğu belirlenmiștir. Çalıșmaya katılanların tamamının ișe girdikten sonra düzenli sağlık kontrolünden geçtiği, çoğunun çalıștıkları firmada ya da daha önce hijyen

\section{ABSTRACT}

Objective: The aim of this study was to determine the knowledge and practice of workers of a catering company in Izmir on food and personal hygiene, and to investigate factors which influence their knowledge and behaviour.

Methods: The cross-sectionally planned study was implemented in the central kitchen of a catering firm having the ISO 22000 Food Safety Management System and in the hospital kitchens served by the firm. It was planned to include all workers ( $n$ : 73 ) of the catering firm to the study however the study was completed with 59 people. The data were collected through the method of the questionnaire and observation by the researcher. Observation was done only with the kitchen workers. The food hygiene knowledge of the workers were scored as sufficient and insufficient while their behaviours were evaluated as appropriate or inappropriate. Data were analyzed with the SPSS 15.0 package program and in comparing the socio-demographic properties and working period with the hygiene knowledge level and behaviour condition chi-square test was used. $p$ value $<0.05$ was noted statistically significant.

Results: The mean age of the workers were $35.4 \pm 7.6$ and $86.4 \%$ of them were working in the kitchen while $13.6 \%$ were food engineer, food technician, secretary, and driver who were not often in the kitchen. It was determined that all workers participating in the study underwent regular medical check-upsafter entering the

* Bu çalıșma; Türkiye Gida ve İçecek Sanayi Dernekleri Federasyonun (TGDF) Gida Kongresinde (12-14 Kasım 2013 Side, Antalya) poster bildirisi olarak sunulmuștur.

1 Şifa Üniversitesi, Sağlık Bilimleri Fakültesi, Beslenme ve Diyetetik Bölümü, IZMiR

2 Dokuz Eylül Üniversitesi, Tıp Fakültesi, Halk Sağlı̆̆ı Anabilim Dalı, IZMiR

3 İzmir Katip Çelebi Üniversitesi, Sağlık Bilimleri Fakültesi Beslenme ve Diyetetik Bölümü, IZMMiR

İletişim/ Corresponding Author : Şadan KÖKSAL

Şifa Üniversitesi, Sağlık Bilimleri Fakültesi, Beslenme ve Diyetetik Bölümü, IZMiR

Tel : +902323080000_ E-posta / E-mail : sadanorun@gmail.com

Geliş Tarihi / Received : 14.07.2015 Kabul Tarihi / Accepted : 24.01.2016

DOI ID : 10.5505/TurkHijyen.2016.39129

Köksal Ș, Soysal A, Ergör G, Kaner G. İzmir'de sağlık kurumlarına yemek üretim ve dağıtım hizmeti veren bir firmada çalıșanların gıda hijyeni ile ilgili bilgi ve davranıșları. Turk Hij Den Biyol Derg, 2016; 73(2): 139-48. 
eğitimi aldıkları ve yarısından fazlasının gıda iș yerinde yedi yıl ve daha az süredir çalıștıkları belirlenmiștir. Bu çalıșmada, çalıșanların yarısından fazlasının $(\% 52,5)$ hijyen bilgi puanının yetersiz olduğu ve gıda hijyenine yönelik davranışlarının $(\% 58,8)$ uygun olmadığı gösterilmiștir. Eğitim durumu gıda hijyeni bilgi puanına anlamlı olarak etki etmektedir $(p=0,029)$. Sosyo-demografik özelliklerin gıda hijyenine yönelik davranıșlara anlamlı etkisi olmadığı saptanmıștır.

Sonuç: Bu çalıșmada, çalışanların çoğu hijyen eğitimi almalarına karșın, gıda hijyeni ve gıda güvenliğine yönelik bilgilerinin yetersiz olduğu belirlenmiş ve bu bilgilerin davranıșa dönüșmediği gözlenmiștir.

Anahtar Kelimeler: Gıda çalıșanları, gıda hijyeni, bilgi, davranıș work and majority of them have had hygiene training courses at their current workplace or before, and more than half of the workers have been working in the food business for 7 years or less. In this study, it was shown that more than half of workers $(52.5 \%)$ had insufficient the level of knowledge of hygiene and inappropriate behaviour $(58.8 \%)$ regarding food hygiene. Educational status is a factor which significantly affects the level of food hygiene knowledge $(p=0,029)$. It was determined that socio-demographic characteristics do not have a significant effect on behaviour concerning food hygiene.

Conclusion: In this study, despite the majority of employees having received hygiene training, it was determined that their knowledge on food hygiene and safety was inadequate and it was observed that these knowledge was not transformed to their behaviours.

Key Words: Food handlers, food hygiene, knowledge, behaviour

\section{GíRiş}

Günümüzde teknolojik gelișmelere, kentleșmeye ve çalışanların sayısındaki artışa paralel olarak toplu beslenme hizmetlerinin önemi giderek artmaktadır. Bugün ileri sanayi ülkelerinde nüfusun \%70'i en az bir öğün yemeği ev dışında yemektedir. Türkiye'de de son yıllarda özellikle ayaküstü yemek (fast-food) restoranlarındaki artışa paralel olarak dışarıda yemek yeme oranı oldukça artmıştır (1).

Kaliteli bir toplu beslenme hizmeti, besin değeri korunmuş (uygun hazırlama ve pişirme teknikleri kullanılarak), ekonomik, hijyenik, yeterli miktarda ve çeșitlilikteki yemeklerin tüketicilerin hoșuna gidecek uygun fiziki koșullarda zarif ve doğru bir biçimde sunum/servis edilmesini gerektirir. Toplu beslenme hizmetlerinde, hijyenik ve kaliteli bir yemek servisinin sağlanamadığı durumlar, gıda kaynaklı hastalıklar ve gıda zehirlenmelerine yol açarak halk sağlığını ve ülke ekonomisini olumsuz yönde etkiler (1).

Gıda kaynaklı hastalıklar, günümüzde gelișmiş ve gelișmekte olan tüm ülkelerde önemli bir halk sağlığı sorununu olușturmakta ve toplum sağlığının korunmasında giderek daha büyük bir önem kazanmaktadırlar (2). Türkiye Halk Sağlığı Kurumu'nun 2014 faaliyet raporuna göre, su ve gida ile bulașan hastalıkların değerlendirilmesinin yapıldığı Haziran - Ekim ayları arasında vaka sayılarında artış olduğu, laboratuvara gönderilen örneklerde ise en fazla belirlenen etkenin rotavirüs olduğu tespit edilmiștir (3). Yapılan bir çalıșmada gıda zehirlenmelerinin önemli bir kısmının gıda maddesi üretimi ve satışının yapıldığı işyerlerinde çalışanların temizlik alıșkanlıklarının yetersizliğinden ve çevresel etmenlerin olumsuzluğundan kaynaklandığ belirtilmiștir (4). Bu konu ile ilgili Mersin illinde yürütülen bir çalışmada, Salmonella ve Shigella taşıyıcılığı ile hepatit A virüs antikoru araștırılmış; bağırsak parazitleri \%4,6 oranında pozitif bulunurken; dıșkı kültüründe patojen bakteri üremediği görülmüștür. Anti-HAV toplam \%84 oranında pozitif olarak bulunmuștur. Bu çalıșmada, gıda yolu ile geçebilecek hastalıkların önlenmesi için gıda ișinde çalışanlara eğitim verilmesinin önemli olduğu vurgulanmıștır (5). 
Gıda ürünleri ile bulaşabilecek hastalıklar, Genetiği Değiștirilmiș Organizma (GDO), yeni üretim teknikleri, kullanılan tarım ilaçları ve benzeri sağlık riskleri, gıda güvenliği ve hijyeni hususunda temel ilkelerin belirlenmesi ihtiyacını doğurmuștur. Bu amaçla, ülkemizde yürürlükte olan 5996 Sayılı Veteriner Hizmetleri, Bitki Sağlığı, Gıda ve Yem Kanunu ile gıda güvenliği ve hijyenine ilișkin hükümler, Avrupa Birliği normlarına uyumlu hale getirilmeye çalıșılmış, uyulması gereken asgari standartlar düzenlenmiștir (6). Ayrıca, gıda hijyeni konusunda çalışanların alacakları eğitimle ilgili hükümler ise yürürlükte olan 1593 sayıl Umumi Hifzıssihha Kanunu'nun 126.-127. maddelerinde düzenlenmiş̦tir. Bu hükümlerin uygulanmasına yönelik 05.07.2013 tarihli Hijyen Eğitimi Yönetmeliği yayımlanmıştır (7). Bu Yönetmelikte, çalışanlara yönelik hijyen eğitimi programlarının planlanmasına, eğitimlerin verilmesine, iş yeri sahibinin, işletenlerin ve çalıșanların bu konudaki sorumluluklarına, bu iş yerlerinde çalıșmaya engel bulașıcı hastalıkların ve cilt hastalıklarının belirlenmesine ve bu hastalıkların iyileșme hâlinin tespitine ilișkin usul ve esaslar belirlenmiştir (7).

Sağlığın korunması ve geliștirilmesi amacıyla yapılan sanitasyon ve hijyen eğitimleri halk sağlığının en önemli konuları arasındadır (8). İtalya'da gıda iși ile uğrașanlarda yapılan bir çalıșmada; gıda ile geçen hastalıkların kontrolü ve önlenmesi için gıda işi ile uğraşanların eğitilmesinin gerekli olduğu bildirilmiștir (9). Gıda çalışanlarının çoğuna hijyen eğitimi verilmesine karșın kişiler, gıda ve kişisel hijyen ile ilgili bilgilerini her zaman davranıșa geçiremeyebilirler. Bu nedenle bu çalışmada, İzmir'deki bir yemek firmasında çalışanların gıda ve kişisel hijyen ile ilgili bilgi ve davranıșlarını belirlenmesi, çalıșanların bilgi ve davranışlarına etki eden etmenlerin saptanması amaçlanmıştır.

\section{GEREÇ ve YÖNTEM}

Kesitsel tipte planlanan bu çalışma, ISO 22000 Gıda Güvenliği Yönetim Sistemine sahip bir yemek firmasının merkez mutfağında ve hizmet verdiği hastane mutfakları ve yemekhanelerinde yürütülmüș, yemek firmasındaki tüm çalıșanların (n:73) çalıșmaya alınması planlanmış, ancak çalışma 59 kişi ile tamamlanmıștır.

Çalışma verileri gözlem yapılarak ve anket uygulanarak toplanmıș, daha önce bu konuda yapılan benzer çalıșmalarda $(10,11)$ kullanılan formlar temel alınarak geliștirilmiștir. Anket formu; genel bilgiler, gida hijyenine yönelik bilgiler ve kișisel hijyen ile ilgili genel bilgiler olmak üzere üç bölümden oluşmuștur. Yaș, cinsiyet, meslek grubu, öğrenim ve medeni durum, iş yerinde çalıșma süresi, düzenli sağlık kontrolünden geçme ve hijyen eğitimi alma durumu bağımsız değișkenler; gıda hijyeni ile ilgili bilgi ve davranıșlar ise bağımlı değişkenler olarak belirlenmiștir.

Çalıșanların gıda hijyenine yönelik davranışları araștırmacının geliștirdiği gözlem formu ile saptanmıștır. Gözlem, yemek firmasının merkez mutfağında ve hizmet verdiği hastanelerin mutfak ve yemekhane bölümlerinde yapılmıștır. Gözlem, her bir birey için yemeklerin hazırlanıp, pişirilip servis edilmesi zaman dilimde yapılmıştır.

Çalıșmamızda, ilk önce gözlem ile davranışa yönelik veriler toplanmış daha sonra çalıșanlardan anket formu ile veri elde edilmiștir. Gözlem ile anket uygulama arasında en az üç gün beklenmiștir.

\section{Gözlem formunun oluşturulması}

Gıda Güvenliği ve Kalitesinin Denetimi ve Kontrolüne Dair Yönetmelik'te EK-2 ve EK-3 olarak verilen "Gıda ve Gıda ile Temasta Bulunan Madde ve Malzemeleri Üreten İșyerlerine Ait Denetim ve Kontrol Formu"nun Personel Hijyeni Bölümünden (12) ve Dokuz Eylül Üniversitesi Hastanesi Beslenme ve Diyet Bölümün hazırladığı çalıșan hijyeni gözlem formundan yararlanılarak geliștirilmiștir.

\section{Gıda hijyeni ile ilgili davranışların değerlendirilmesi}

Gıda hijyeni ve güvenliğine yönelik belirlenen 12 davranış, gözlem formu ile araștırmacı tarafından yemeğin hazırlanmasından servisine kadar 
geçen sürelerde gözlenerek evet ve hayır olarak işaretlenmiștir. Erkek personel için saç ve sakal trașı olma, kadınlar için saçlarının toplu olup olmadığı gözlenmiștir. Bone ya da kep kullanma, tırnakların kısa ve temiz olması, yemeklerin tat kontrolünün uygun șekilde yapılıp yapılmadığı, kıyafetlerin temiz ve ütülü olması, çalıșırken eldiven kullanılması, ișe bașlamadan önce ellerin hijyenik șekilde yıkanması, maske takılması, mutfakta ve yemek servisinde sigara içilmesi, çiğ ve pișmiş gıdanın birlikte bekletilmesi, gözle görülür bir hastalık belirtisi, elde görünür bir yara ve/veya lezyon olup olmadığı gözlenmiștir.

Analizlerde davranış durumu 'uygun' ve 'uygun değil' olarak iki grupta değerlendirilmiștir. Uygun olan davranıșa 1 (bir) puan, uygun olmayan davranışa da 1 (bir) puan verilerek her bir katılımcı için davranış puanı hesaplanmış ve puanların ortalaması alınmıștır. 12 davranıștan en az bir davranışı uygun olmayanların davranıșı uygun değil, tüm davranışları uygun olanların davranıșları uygun kabul edilmiștir. Mutfak çalışanı olmayan, gıda mühendisi, gıda teknikeri, sekreter ve şoförden olușan meslek gruplarından kişilerin davranışları gözlenmemiștir.

\section{Gıda hijyeni ile ilgili bilgi düzeyinin değerlendirilmesi}

Katılımcılara, gıda hijyeni ve güvenliği ile ilgili 21 bilgi ve soru yöneltilerek "evet", "hayır" ve "bilmiyorum" seçeneklerini kullanarak yanıt vermeleri istenmiștir. Yanıtlar doğru, yanlıș ve bilmiyor olarak değerlendirilmiștir. Çözümlemede doğru yanıt 1 (bir), yanlıș yanıt 1 (bir) ve bilmiyorum 0 (sıfır) puan olarak değerlendirilerek çalıșmaya katılan her çalıșanın bilgi puanı elde edilmiștir. Bilgi puanlarının ortalaması alınarak, ortalama puanda ve altında kalanlar yetersiz, ortalamanın üstünde puana sahip olanlar yeterli bilgi düzeyine sahip kabul edilmiștir.

\section{Hijyen eğitimi alma}

Çalıșmaya katılan çalıșanların tamamına yakınına $(\% 93,2)$ Hijyen Eğitimi Yönetmeliğine uygun olarak firmada çalışan gıda mühendisi tarafından on saatlik hijyen eğitimi verilmiștir. Eğitim, aynı yönetmeliğin sekizinci maddesine uygun olarak (7);

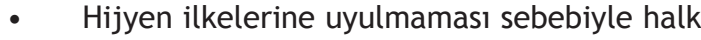
sağlığı açısından risk olușturduğu bilinen virüslerin, bakterilerin, parazitlerin, mantarların ve diğer enfeksiyon etkenlerinin genel özellikleri,

- Bulașma yolları, hangi iș kolunda nasıl bulașmalar olabileceği veya halk sağlığının nasıl tehdit göreceği,

- Hastalık belirtileri ve korunma yolları gibi konulardan olușmuștur.

\section{İstatistiksel analiz}

Analizlerde, SPSS 15.0 paket programı kullanılmıștır. Sosyo-demografik özellikler ve çalıșma süresinin hijyen bilgi düzeyi ve davranıș durumu ile karșılaștırılmasında ki-kare testi kullanılmıștır. $p<0,05$ anlamlı kabul edilmiştir (13). Bu çalışma için, Dokuz Eylül Üniversitesi Tıp Fakültesi Etik Kurulu'ndan 25-05-2009 nolu onay alınmıștır. Bireylere çalıșma içeriği ve amacı ile ilgili genel bir bilgi verilmiş, çalıșmaya katılmayı kabul eden her katılımcı onam formunu okuyup imzalamıștır.

\section{BULGULAR}

Çalışanların \%55,9'u kadın, \%44,1'i erkek olup yaș ortalaması $35,4 \pm 7,6$ 'dır. Bununla birlikte $\% 86,4$ 'ü mutfak çalıșanı, \%13,6'sı her zaman mutfakta bulunmayan, gıda mühendisi, gıda teknikeri, sekreter ve șoförden olușmaktadır. Öğrenim durumu \%62,7'sinde ilkokul ve altı iken \%47,3'ünde ortaokul ve üzeridir. Çalıșanların tamamının düzenli olarak sağlık kontrolünden geçtiği, \%93,2'sinin hijyen eğitimi aldığı belirlenmiștir. Ayrıca çalıșanların \%67,8'si toplu beslenme sektöründe yedi yıl ve daha az çalıștığını belirtmiștir. Gıda hijyeni ve güvenliğine yönelik bilgilerin değerlendirilmesi Tablo 1'de gösterilmiștir. Çalıșanların \%13,6'sı çiğ ve pișmiș gıdalar birlikte bekletilebilir cümlesine "evet” diyerek yanlış cevap vermiștir. Yemeye hazır sıcak gıdaları korumak için doğru sıcaklık aralığını katılımcıların yarısından fazlası $(\% 54,2)$ yanlıș bilmektedir. Katılımcıların yarısından 
fazlası $(\% 59,3)$ dondurulmuș gıdalar oda sıcaklığında bekletilerek çözdürülür diyerek; büyük çoğunluğu $(\% 76,3)$ ise dondurulmuş gidalar $-5{ }^{\circ} \mathrm{C}$ 'de saklanabilir diyerek yanlıș cevap vermișlerdir (Tablo 1 ).

Çalışanların hiyene yönelik gözlenen bazı davranışlarının dağı̆ımı Tablo 2'de gösterilmiștir.

Çalışanların tamamının bone ya da kep taktığı, \%98,0'inin tırnaklarının temiz ve kısa olduğu gözlenmiștir. Ayrıca, \%88,2'sinin temiz ve ütülü kıyafetle çalıștığı ve çalıșırken eldiven kullandığı, \%80,4'ünün işe bașlamadan önce ellerini yıkadığı, $\% 60,8^{\prime}$ inin çalıșırken maske kullandığı ve \%5,9'unun mutfak ya da yemek servisinde sigara içtiği gözlenmiștir (Tablo 2).

Tablo 1. Gıda hijyeni ve güvenliğine yönelik bazı bilgilerin değerlendirmesi

\begin{tabular}{|c|c|c|c|c|c|c|c|}
\hline & \multirow{2}{*}{$\begin{array}{l}\text { Doğru } \\
\text { Yanitlar }\end{array}$} & \multicolumn{2}{|c|}{ Doğru Yanıt } & \multicolumn{2}{|c|}{ Yanlış Yanıt } & \multicolumn{2}{|c|}{ Bilmiyor } \\
\hline & & Sayı & $\%$ & Sayı & $\%$ & Sayı & $\%$ \\
\hline Bone, maske, eldiven giymek yiyeceklere mikrop bulașma riskini azaltır. & Evet & 59 & 100,0 & 0 & 0,0 & 0 & 0,0 \\
\hline Yiyeceklere dokunmadan önce ellerin yıkanması bulașma riskini azaltır. & Evet & 57 & 96,6 & 2 & 3,4 & 0 & 0,0 \\
\hline Mutfakta çalıșan kadınların tırnakları ojeli olabilir. & Hayır & 57 & 96,6 & 1 & 1,7 & 1 & 1,7 \\
\hline İnsanlar, gıdalara zararlı bakterilerin bulașmasında aracıdırlar. & Evet & 51 & 86,4 & 8 & 13,6 & 0 & 0,0 \\
\hline Çiğ gıdalar ile pișmiş gıdalar birlikte bekletilebilir. & Hayır & 50 & 84,7 & 8 & 13,6 & 1 & 1,7 \\
\hline Buzdolabı için doğru sıcaklık aralığı $\left({ }^{\circ} \mathrm{C}\right)$ & $0-5^{\circ} \mathrm{C}$ & 45 & 76,3 & 14 & 23,7 & 0 & 0,0 \\
\hline Çözünmüşs gıdalar yalnızca 1 (bir) kez daha dondurulabilir. & Hayır & 31 & 52,5 & 28 & 47,5 & 0 & 0,0 \\
\hline Yenmeye hazır sıcak gıdaları korumak için doğru sıcaklık aralığı $\left({ }^{\circ} \mathrm{C}\right)$ & $61-70^{\circ} \mathrm{C}$ & 27 & 45,8 & 32 & 54,2 & 0 & 0,0 \\
\hline Dondurulmuş gıdalar oda sıcaklığında bekletilerek çözdürülür. & Hayır & 23 & 39,0 & 35 & 59,3 & 1 & 1,7 \\
\hline Dondurulmuş gıdalar $-5^{\circ} \mathrm{C}$ 'de saklanabilir. & Hayır & 11 & 18,6 & 45 & 76,3 & 3 & 5,1 \\
\hline
\end{tabular}

Tablo 2. Çalıșanların hijyene yönelik gözlenen bazı davranıșlarının dağılımı*

\begin{tabular}{lcccc}
\hline \multirow{2}{*}{ Gözlenen davranışlar (n=51) } & \multicolumn{2}{c}{ Evet } & & \multicolumn{2}{c}{ Hayır } \\
\cline { 2 - 3 } \cline { 5 - 5 } Bone ya da kep takmıș mı? & Sayı & $\%$ & Sayı & \% \\
Tırnakları kısa ve temiz mi? & 51 & 100,0 & 0 & 0,0 \\
Yemeklerin tat kontrolünü uygun șekilde yapıyor mu? & 50 & 98,0 & 1 & 2,0 \\
Kıyafetleri temiz ve ütülü mü? & 49 & 96,1 & 2 & 3,9 \\
Çalıșırken eldiven kullanıyor mu? & 45 & 88,2 & 6 & 11,8 \\
İșe bașlamadan önce ellerini hijyenik șekilde yıkıyor mu? & 45 & 88,2 & 6 & 11,8 \\
Maske takıyor mu? & 41 & 80,4 & 10 & 19,6 \\
Mutfakta ve yemek servisinde sigara içiyor mu? & 31 & 60,8 & 20 & 39,2 \\
Çiğ ve pișmiș besini birlikte bekletiyor mu? & 3 & 5,9 & 48 & 94,1 \\
Gözle görülür bir hastalık belirtisi var mı? & 2 & 3,9 & 49 & 96,1 \\
Elinde görünür yara lezyon var mı? & 1 & 2,0 & 50 & 98,0 \\
\hline
\end{tabular}

* Mutfak çalıșanı olmayanlar (sekiz kiși) gözleme alınmamıștır. 
Tablo 3. Çalıșanların sosyo-demografik özeliklerinin gıda hijyeni bilgi düzeylerine ve gıda hijyenine yönelik davranıșlarına etkisi

\begin{tabular}{|c|c|c|c|c|c|c|c|c|c|c|}
\hline & \multicolumn{4}{|c|}{ Hijyen Bilgi Düzeyi } & \multirow{3}{*}{$\underset{\text { değeri }}{\mathrm{p}}$} & \multicolumn{4}{|c|}{ Davranış Durumu } & \multirow{3}{*}{$\underset{\text { değeri }}{\mathrm{p}}$} \\
\hline & \multicolumn{2}{|c|}{ Yeterli } & \multicolumn{2}{|c|}{ Yetersiz } & & \multicolumn{2}{|c|}{ Uygun } & \multicolumn{2}{|c|}{ Uygun değil } & \\
\hline & Sayı & $\%$ & Sayı & $\%$ & & Sayı & $\%$ & Sayı & $\%$ & \\
\hline \multicolumn{11}{|l|}{ Cinsivet } \\
\hline Kadın & 19 & 53,8 & 14 & 46,2 & \multirow{2}{*}{0,542} & 14 & 48,3 & 15 & 51,7 & \multirow{2}{*}{0,371} \\
\hline Erkek & 12 & 42,4 & 14 & 57,6 & & 7 & 31,8 & 15 & 68,2 & \\
\hline \multicolumn{11}{|l|}{$\underline{\text { Yaș }}$} \\
\hline$\leq 35$ & 17 & 51,5 & 16 & 48,5 & \multirow{2}{*}{0,660} & 10 & 37,0 & 17 & 63,0 & \multirow{2}{*}{0,725} \\
\hline$\geq 36$ & 11 & 42,3 & 15 & 57,3 & & 11 & 45,8 & 13 & 54,2 & \\
\hline \multicolumn{11}{|l|}{ Öğrenim durumu } \\
\hline İlkokul ve altı & 13 & 35,1 & 24 & 64,9 & \multirow{2}{*}{$0,029^{*}$} & 14 & 38,9 & 22 & 61,1 & \multirow{2}{*}{0,840} \\
\hline Ortaokul ve üzeri & 15 & 68,2 & 7 & 31,8 & & 7 & 46,7 & 8 & 53,3 & \\
\hline \multicolumn{11}{|l|}{ Çalıșma süresi } \\
\hline$\leq 7$ yll & 17 & 42,5 & 23 & 57,5 & \multirow{2}{*}{0,408} & 13 & 37,1 & 22 & 62,9 & \multirow{2}{*}{0,576} \\
\hline$\geq 8 \mathrm{yll}$ & 11 & 57,9 & 8 & 42,1 & & 8 & 50,0 & 8 & 50,0 & \\
\hline \multicolumn{11}{|l|}{ Medeni durum } \\
\hline Evli & 18 & 46,2 & 21 & 53,8 & \multirow{2}{*}{0,996} & 16 & 45,7 & 19 & 54,3 & \multirow{2}{*}{0,505} \\
\hline Evli değil & 10 & 50,0 & 10 & 50,0 & & 5 & 31,3 & 11 & 68,7 & \\
\hline
\end{tabular}

* Pearson ki-kare

Çalıșmamızda; çalıșanların gıda hijyeni bilgi puanlarının ortalamasının $12,04 \pm 4,4$; davranıș puanlarının ortalamasının $10,02 \pm 2,2$ olduğu saptanmıștır. Bununla birlikte, çalıșanların yarısından fazlasının $(\% 52,5)$ hijyen bilgi puanı yetersiz olup gıda hijyenine yönelik davranıșları $(\% 58,8)$ uygun değildir.

Tablo 3'te çalışanların sosyo-demografik özeliklerinin gıda hijyeni bilgi düzeylerine ve gıda hijyenine yönelik davranıșlarına etkisi gösterilmiștir. Erkeklerin \%42,4'ü, kadınların \%53,8'i; 35 yaș ve altında olanların yaklașık yarısı $(\% 51,5)$ yeterli hijyen bilgi puanına sahiptir. Ayrıca, öğrenim düzeyi ortaokul ve üzerinde olanların $\% 68,2$ 'si, çalıșma süresi sekiz yıl ve üstünde olanların \%57,9'u yeterli hijyen bilgi puanına sahiptir (Tablo 3).

Kadınların yaklaşık yarısının $(\% 48,3)$, erkeklerin $(\% 31,8)$ ve 35 yaș altında $(\% 37,0)$ olanların üçte birinin gıda hijyenine yönelik davranıșları uygundur. Ayrıca, öğrenim durumu ortaokul ve üzeri $(\% 46,7)$, çalıșma süresi sekiz yıl ve daha fazla $(\% 50,0)$, medeni durumu evli olanların yaklașık yarısının $(\% 45,7)$ gıda hijyenine yönelik davranıșları uygundur (Tablo 3).

\section{TARTIȘMA}

Çalıșmamızda, İzmir'de bulunan bir yemek firmasının merkez mutfağında ve hizmet verdiği hastane mutfakları ve yemekhanelerinde çalıșan personelin, gıda hijyeni ve kișisel temizlik ile ilgili bilgi ve davranıșları araștırılmıș ve bilgi ve davranıșlarına etki eden etmenler belirlenmiștir.

Çalışanların yarıdan fazlasının $(\% 67,8)$ iş yerinde çalıșma süresi yedi yıl ya da daha azdır. Bu konu ile ilgili, Ankara'da kamu kurumlarının yemekhanelerinde çalışan mutfak personelinin el 
hijyen bilgisi ve uygulamalarının incelendiği benzer bir çalıșmada, çalıșanların yarıya yakınının $(\% 42,0)$ iș yerinde çalıșma süresinin bir ile on yıl arasında olduğu saptanmıștır (14). Toplu beslenme hizmeti veren işyerlerinde çalışanların çoğunun orta yaş altında olması nedeniyle, işyerlerinde istihdamın sürekli olmadığı, kamu kurumlarının bir çoğunun yemek hizmeti satın aldığı için belirli dönemlerde hizmet veren firmaların değișmesine bağı çalıșanların sıklıkla değiștiği söylenebilir.

Gıda güvenliği ve hijyenine ilișkin hususlarının düzenlendiği 5996 Sayılı Kanun 11.06.2010 tarihinde kabul edilmiștir. Özellikle Avrupa Birliği müktesebatına uyum sağlanmasının amaçlandığı bu kanun gıda ürünlerinin üretiminden bașlayarak tüketiciye ulașana kadar geçen her safhasını kapsamaktadır (6). Gıda, Tarım ve Hayvancılık Bakanlığı tarafından, 5996 Sayılı Kanunun uygulanması amaciyla Gida ve Yemin Resmi Kontrollerine Dair Yönetmelik, Gıda Hijyeni Yönetmeliği, Hayvansal Gıdalar İçin Özel Hijyen Kuralları Yönetmeliği ve Türk Gıda Kodeksi Yönetmeliği çıkarılmıștır. Ayrıca gıda hijyeni konusunda çalıșanların alacakları eğitimle ilgili hükümler yürürlükte olan 1593 sayılı Umumi Hifzıssihha Kanunu'nun 126 ve 127. maddelerinde düzenlenmektedir. Bu hükümlerin uygulanmasına yönelik 05.07.2013 tarihli Hijyen Eğitimi Yönetmeliği çıkarılmışıı (7). Umumi Hıfzıssıhha Kanunun 126. maddesinde, gıda üretim ve satış yerleri ve toplu tüketim yerlerinde iş yeri sahipleri, çalışanlarına hijyen konusunda gerekli eğitimi vermeye veya çalıșanların bu eğitimi almalarını sağlamakla yükümlü olduklarını belirtmektedir (7). Bu çalışmada, çalıșmaya katılanların hepsi ișe girdikten sonra düzenli sağlık kontrolünden geçtiklerini, büyük çoğunluğu $(\% 93,2)$ çalıștıkları firmada ya da daha önce hijyen eğitimi aldıklarını belirtmişlerdir. Çalışmamız, ISO (International Standarts Organizations, Uluslar Arası Standartlar Organizasyonu) 22000 Gida Güvenliği Yönetim Sistemine sahip bir firmada yürütülmüștür. $\mathrm{Bu}$ yönetim sistemi; uluslararası düzeyde sağlık, çevre ve çeșitli üretim alanlarına göre değişebilen, hijyen ve kalitenin korunmasına yönelik uygulamaları içermektedir. Ayrıca riskli davranışların önlenmesi, hijyen eğitimleri ve uygulamalarına ek olarak toplum temelli programların hazırlanması ve yürütülmesi de bu yönetim sisteminde oldukça önemlidir (8). Ancak, ülkemizde bu yönetim sistemlerinin kullanımı ile ilgili yasal bir zorunluluk olmadığı için sınırlı sayıda yapılmaktadır. Bu çalıșmamızda, çalıșanların tamamına yakınının $(\% 93,2)$ hijyen eğitimi alması; firmanın ISO 22000 Gıda Güvenliği Yönetim Sistemine sahip olmasından kaynaklandığını düşündürmüștür. ISO Gıda Güvenliği Yönetim Sistemini kullanmayan gıda iș yerlerinde yapılan bir çalıșmada; çalıșanların \%58,3'nün ișe girerken sağlık kontrolünden geçmediği, \%75,8'nin periyodik sağlık kontrolünden geçmediği, \%75,6'sının hijyen eğitimi almadığı belirlenmiștir (8).

Portekiz'de huzurevi ve anaokullarında yapılan çalıșmada; çalıșanların 12 ay öncesinde hijyen eğitimi almaları ile gıda hijyeni bilgi düzeyleri arasında pozitif anlamlı bir ilișki bulunmuștur (15). Clayton ve ark. (16); İngiltere'de yaptıkları çalıșmada, çalışanların \%95,0'inin gıda hijyeni eğitimi aldıkları halde \%63,0'ünün bazen bildiklerini uygulamadıkları bulunmuștur. Çiğli'deki yemek firmasında yürütülen bu çalıșmada da hijyen eğitim alma oranı yüksek olmasına karșın, çalıșanların \%58,8'inin gıda hijyenine yönelik davranışlarının uygun olmadığı belirlenmiștir. Aynı zamanda, çalıșanların gıda güvenliği ile ilgili bilgilerinin (dondurulmuş gıdaları ve yenmeye hazır sıcak gıdaları uygun saklama dereceleri) eksik olduğu görülmüștür. Çalıșmamızda elde edilen sonucun benzer çalıșmaların sonuçlarıyla benzerlik gösterdiği tespit edilmiștir (17-21).

Yemek üretim ve dağıtım hizmeti veren bir firmada gıdalara kirleticilerin bulaşmaması için koruyucu giysilerin kullanımı çok önemlidir. İșletmede çalıșan herkes potansiyel bir mikroorganizma taşıyıcısı ve bu alanlarda olușan kirlenmenin ve çapraz bulașmanın en önemli kaynağıdır. Hastalık, yara, yanık ve kesiklerin, vücut döküntü ve salgıları ile giysilerin, aynı zamanda ellerin dikkat edilmesi gereken noktaların başında geldiği görülmüştür (22). Çalıșmamızda; çalıșanlara iş üniforması dışında neler giydikleri sorulmuş, tamamının bone ya da kep kullandığı, tamamına yakınının da 
önlük, maske ve kolluk kullandıkları belirlenmiștir. Edirne II merkezindeki hastane mutfaklarında yapılan bir çalıșma sonucunda, tüm çalıșanların özel iș elbisesi, özel mutfak ayakkabısı, bone-kep kullandığı saptanmıștır (22). Samsun il merkezindeki hastane mutfaklarının hijyen durumunun değerlendirildiği bir çalıșmada ise mutfak personelinin \%50'sinin kep kullanmadığı, \%62,5'inin iș dıșı giysilerini iş öncesi değiștirmeye gerek duymadığı saptanmıștır (23).

Gıda işyerinde çalışanların maske kullanımı hastalık etkenlerinin gıdalara bulaşmasını önlemede etkili bir yöntemdir. Çalıșmamıza katılan çalıșanlardan yaklaşık \%40'ının çalıșırken maske, \%12'sinin ise eldiven kullanmadığı tespit edilmiștir. Yapılan benzer bir çalıșmanın sonucunda; hastane mutfaklarında çalışanların \%40’ının eldiven, \%80'inin maske kullanmadığı saptanmıștır (22). Bu çalışmamızda; çalıșanların yaklaşık \%40'ının, çalıșırken maske kullanmıyor olması, çalıșmanın yürütüldüğü firmanın, HACCP (Hazard Analysis and Critical Control Points-Tehlike Analizi ve Kritik Kontrol Noktaları) sistemini temel alan ISO 22000 gıda güvenliği yönetim sistemine sahip olması açısından düşündürücüdür. HACCP sisteminin oluşturulması ve etkin bir șekilde uygulanması için belirli bir sürece ihtiyaç olmasına rağmen, hazır yemek üreten firmaların çoğu bu kalite ve yönetim sistemlerine kolayca sahip olmaktadırlar.

El yıkamak, gıda güvenliğinin sağlanmasında, besin kaynaklı hastalıkların önlenmesinde ve gıda sektöründe hizmet kalitesinin arttırılmasında en ucuz ve en güvenilir yöntemdir (24). Çalıșmamızda, firma çalıșanlarının yaklașık \%20'sinin ișe bașlamadan önce ellerini hijyenik bir șekilde yıkamadığı gözlenmiștir. Clayton ve Griffith'in (25) yaptığı çalıșmada; çalıșanların sadece \%10'unun iș aktiviteleri esnasında kirli yüzey, ekipman ve gereçlere temas ettikten sonra ellerini yıkadığı belirlenmiștir. Brezilya'da yapılan farklı bir çalıșmada; çalıșanların sürekli hijyen eğitimi almalarına karșın, \%53,3'ünün ellerinden alınan örneklerde stafilokok belirlenmiștir (26).

$\mathrm{Bu}$ çalıșmamızda, çalıșanların yarısından fazlasının gıda hijyeni bilgi düzeylerinin yetersiz, davranıșlarının uygun olmadığı görülmüștür. Gıda güvenliği yönetim sistemini uygulayan bir firmada, bu sonucun elde edilmesi düșündürücüdür. İtalya'da iki ayrı hastanede yürütülen bir çalıșmanın sonucunda; gıda dağıtımında çalıșanların gıda güvenliği ile ilgili bilgilerinin yetersiz olduğu ve hastanelerde güvenli bir gıda yönetim sisteminin uygulanması gerektiği belirtilmiștir (27). Ankara'daki dört ve beș yıldızlı otellerde çalıșan yiyecek ve içecek personelinin hijyen bilgileri ve uygulamalarının incelendiği farklı bir çalıșmada; 102 çalıșandan 25 kișinin yeterli bilgiye sahip olduğu belirlenmiștir (28). Yapılan benzer çalıșmalarda da hijyen bilgisi eksikliğinin, kritik kontrol noktalarını belirleme ve gıda güvenliğini sağlamada engel olduğu belirtilmiș ve hijyen eğitiminin önemi vurgulanmıștır (29-32). Çalıșmamızda, öğrenim durumunun gıda hijyeni bilgi düzeyine anlamlı etkisi olduğu saptanmış, öğrenim durumu ilkokul ve altı olan 37 kișiden 24'ünün hijyen bilgi puanlarının yetersiz olduğu belirlenmiștir $(p=0,029)$. Sivas Il merkezinde 494 kișide yapılan farklı bir çalıșmada; bireylerin ancak yarısının genel görünüm, saç, sakal, tırnak, yüz, el, giysi gibi kișisel hijyen özelliklerinin iyi olduğu, lise ve üzeri eğitim alanlarda bu oranların anlamlı olarak daha yüksek olduğu saptanmıștır (33). Üniversiteli gençler arasında yapılan bir çalışmada da gıda hijyeni bilgi düzeyi ile üniversite son sınıf olma ve eğitim alanı arasında ilișki olduğu belirlenmiștir (34). Çanakkale'de yapılan farklı bir çalıșmada da genel olarak çalıșma ortamı ve kişisel hijyen sorularına doğru cevaplar verilmiș, özellikle üniversite eğitimi alanlarda tam puan alanların oranı anlamlı olarak daha yüksek belirlenmiștir (35). İtalya'da yapılan farklı bir çalıșmada, hastanelerde gıda hijyeni ile ilgili bilgi, tutum ve uygulamalar incelenmiş ve 290 çalışandan \%78,8'inin gıda kaynaklı patojenlere yol açan beș etkeni bilmediği ve bilgi düzeyinin eğitim düzeyinin artmasıyla arttığı saptanmıștır (36).

Bu çalıșmamızda, davranış durumuna öğrenim durumunun anlamlı etkisi olmadığı ancak öğrenim durumu ilkokul ve altı olanlarda davranıș durumu uygun 
olmayanların yüksek oranda olduğu belirlenmiștir. Aradaki farkın anlamlı bulunmamasının nedeni gıda mühendisi ve gıda teknikeri gibi eğitim seviyesi yüksek kişilerin araștırmacı tarafından gözlemden çıkarılması olabileceğini düşündürmüștür.

\section{Çalışmanın kısıtlııkları}

$\mathrm{Bu}$ çalıșmamızda, kurumlardan izin alma sorunu nedeniyle tek bir yemek firmasının merkez mutfağı ve hizmet verdiği hastane mutfaklarında yapılması ve çalıșmaya katılan kiși sayısının az olması çalıșma sonucunun yemek üretim ve dağıtım hizmeti veren tüm firmalar için genellemesini engelleyebilir. Ancak çalıșmada elde edilen sonuçlar, çalıșma alanı kısıtlı olsa da yemek üretim ve dağıtım hizmeti sunulan toplum kesitinin büyüklüğü nedeniyle önemli olacağını düşündürmektedir.

\section{SONUÇ}

Bu çalıșma, ISO 22000 Gıda Güvenliği Yönetim Sistemine sahip bir firmada yürütülmüș olmasına ve çalıșanların tamamına yakınına hijyen eğitimi verilmiş olmasına rağmen gıda hijyeni ve gıda güvenliğine yönelik bilgilerinin yetersiz olduğu belirlenmiș ve bu bilgilerin davranışa dönüșmediği gözlenmiştir. Gıda işyerinde çalışanların öncelikle hijyen konusunda eğitilmiş olmaları, işletmede sağlıklı bir üretim için önemlidir. Bu nedenle gıda çalıșanlarına yönelik olarak verilen hijyen eğitimlerinin davranıșa dönüșebilmesini sağlayacak yöntemler geliștirilmelidir.

\section{TEŞEKKÜR}

Çalıșmamızda; veri toplama așamasında katılan ve destek olan tüm firma çalıșanlarına teșekkür ederiz.

\section{ÇIKAR ÇATIŞMASI}

Yazarlar herhangi bir çıkar çatıșması bildirmemektedir.

\section{KAYNAKLAR}

1. Bilici S. Toplu beslenme sistemleri çalıșanlan için hijyen el kitabı. Ankara: T.C Sağıı Bakanlığı Temel Sağlık Hizmetleri Genel Müdürlüğü Beslenme ve Fiziksel Aktiviteler Daire Bașkanlığı Beslenme Bilgi Serisi, 2008.

2. Alpuğuz G, Erkoç F, Mutluer B, Selvi M. Gençlerin (14-24 yaș) gıda hijyeni ve ambalajlı gıdaların tüketimi konusundaki bilgi ve davranıșlarının incelenmesi. Türk Hij Den Biyol Derg, 2009; 66(3): 107-15.

3. Anonymous. 2014 Faaliyet Raporu. Ankara: T.C. Sağlık Bakanlığı, Türkiye Halk Sağlığı Kurumu, 2014.

4. Serbil S, Tümerdem Y, Kıyak M, Hacıoğlu S. İstanbul Küçükçekmece ilçesinde fırınların hijyenik yönden değerlendirilmesi. Türk Hij Den Biyol Derg, 2001; 58(3): 93-6.

5. Delialioğlu N, Aslan G, Öztürk C, KayaA, Ersöz G. Gıda çalışanlarında gıda kaynaklı hastalık etkenlerinin vetașıyıcılık durumunun değerlendirilmesi. Türk Hij Den Biyol Derg, 2003; 60(1):19-2.
6. 5996 Sayılı Veteriner Hizmetleri, Bitki Sağlığı, Gıda ve Yem Kanunu,http://www.resmigazete.gov.tr/ eskiler/2010/06/20100613-12.htm. (Erișim tarihi: 15.12.2015).

7. Hijyen Eğitimi Yönetmeliği,http://www. resmigazete.gov.tr/eskiler/2013/07/20130705-3. htm. (Erişim tarihi: 15.12.2015).

8. Cevizci S, Önal AE. Halk sağıığı açısından hijyen ve iyi üretim uygulamaları. Türk Hij Den Biyol Derg, 2009; 66(2): 73-82.

9. Angelillo IF, Viggiani NM, Rizzo L, Bianco A. Food hand lersand food borne disease: knowledge, attitudes, and reported behavior in Italy. J Food Prot, 2000; 63(3): 381-5.

10. Baș M, Temel MA, Ersun AS, Kıvanç G. Prerequisite program sand food hygiene in hospitals: Food safety know ledge and practices of food service staff in Ankara, Turkey. Infect Control Hosp Epidemiol, 2005; 26(4): 420-24. 
11. Tokuç B, Ekuklu G, Berberoğlu U, Bilge E, Dedeler $\mathrm{H}$. Knowledge, attitudes and self reported practices of food service staff regarding food hygiene in Edirne, Turkey. Food Control, 2009; 20(6): 565-68.

12. Gıda Güvenliği ve Kalitesinin Denetimi ve Kontrolüne Dair Yönetmelik, http://www.resmigazete.gov.tr/ eskiler/2008/09/20080926-4.htm. (Erișim tarihi: 3.12.2008).

13. Aksakoğlu G. Sağlıkta araștırma ve çözümleme. 2. Baskı. İzmir: Dokuz Eylül Rektörlük Basımevi, 2006.

14. Turan i. Mutfak personelinin el hijyeni bilgisi ve uygulamalarının incelenmesi. Yüksek Lisans Tezi, Ankara Üniversitesi Fen Bilimleri Enstitüsü, 2009.

15. Martins RB, Ferreira D, Moreira LM, Hogg T, Gestal $\mathrm{J}$. Knowledge on foodhygiene of food service staffworking in nursing home sand kinder gartens in Porto region-Portugal. Food Control, 2014; 42: 54-62.

16. Clayton DA, Griffith CJ, Price P, Peters AC. Food handlers' beliefs and self-reported practices. Int J Environ Health Res, 2002; 12(1): 25-39.

17. Sani NA, Siow ON. Knowledge, attitudes and practices of food handlers on food safety in food service operations at the Universiti Kebangsaan Malaysia. Food Control, 2014; 37: 210-17.

18. Tan SL, Bakar FA, Abdul Karim MS, Lee HY, Mahyudin NA. Hand hygiene knowledge, attitude sand practice samong food handlers at primary schools in Hulu Langat district, Selangor (Malaysia). Food Control, 2013; 34(2): 428-35.

19. Sun YM, Wang ST, Huang KW. Hygiene knowledge and practices of night market foodvendors in Tainan City, Taiwan. Food Control, 2012; 23(1): 159-64.

20. Giritlioğlu I, Batman O, Tetik N. The knowledge and practice of food safety and hygiene of cookery students in Turkey. Food Control, 2011; 22(6): 838-42.

21. Pang J, Chua SWJL, Hsu L. Current know ledge, attitude and behaviour of hand and food hygiene in a developed residential community of Singapore: a crosssectional survey. BMC Public Health, 2015; 15(577): 1-12.

22. Sert Ş, T. Edirne il merkezindeki hastanelerde mutfak personel hijyeninin belirlenmesi üzerine bir araștırma. Yüksek Lisans Tezi, Trakya Üniversitesi Fen Bilimleri Enstitüsü, 2006.

23. Dündar C, Elmacioğlu $F$, Topbaș $M$, Pekșen $Y$. Samsun il merkezindeki hastane mutfaklarının hijyen durumunun değerlendirilmesi. Turk Hij Den Biyol Derg, 2000; 57(1):1-6.
24. Dokuzoğuz B. El hijyeni. Türkiye Klinikler Mikrobiyol Enfek Derg, 2003; 2(2): 79-84.

25. Clayton D, Griffith C. Observation of food safety practices in cateringusing not ationalanalysis. Brit Food J, 2004; 106(3): 211-27.

26. Soares LS, Almeida RCC, Cerqueira ES, Carvalho JS, Nunes IL. Knowledge, attitude sand practices in food safety and the presence of coagulase-positive staphylococci on hands of food handlers in the schools of Camaçari, Brazil. Food Control, 2012; 27(1): 206-13.

27. Buccheri C, Casuccio A, Giammanco S, Giammanco M, Guardia ML, Mammina C. Food safety in hospital: knowledge, attitude sand practices of nursing staff of two hospitals in Sicily, Italy. BMC HealthServRes, 2007; 7: 45

28. Sargın Y. Ankara'daki dört ve beș yıldızlı otellerde çalıșan yiyecek ve içecek personelinin hijyen bilgilerinin ve uygulamalarının incelenmesi. Yüksek Lisans Tezi, Trakya Üniversitesi Fen Bilimleri Enstitüsü, 2005.

29. Walker E, Pritchard C, Forysthe S. Foodhandlers hygiene know ledge in small food businesses. Food Control, 2003; 14 (5): 339-43.

30. Baș M, Ersun AȘ, Kıvanç G. Implementation of HACCP and prerequisite programs in food businesses in Turkey. Food Control, 2006; 17 (2): 118-26.

31. Aarnisalo K, Tallavaara K, Wirtanen G, Maijala $\mathrm{R}$, Raaska L. The hygienic working practices of maintenance personel and equipment hygiene in the Finnish food industry. Food Control, 2006; 7(12): 1001-11.

32. Seaman $P$, Eves A. The management of food safety the role of food hygiene training in the UK service sector. Int J Hosp Manage, 2006; 25(2): 278-96.

33. Koçoğlu G, Sümer H, Nur N, Polat H. Gıda maddesi üreten ve satan yerlerde çalışanların sanitasyon konusunda bilgi düzeyleri. 8. Ulusal Halk Sağlığı Kongresi. Diyarbakır, 23-28 Eylül 2002.

34. Low WY, Jani R, Abdul Halim H, Alias AA, MingMoy F. Determinants of food hygiene know ledge amongy ouths: A cross-sectional online study. Food Control, 2016; 59: 88-93.

35. Cakır F, Colakoğlu FA, Berik N. Su ürünleri İșleyen ve satan yerlerde çalıșanların sanitasyon konusunda bilgi düzeyleri. Ege J FAS, 2006; 23(1/3): 377-81.

36. Angellio IF, Viggiani MA. HACCP and food hygiene in hospital: knowledge, attitudes, and practices of food servicess taff in calabria, Italy. Infect Cont Hosp Epidemiol, 2001; 22(6): 363-69. 


\section{İstanbul'un sivrisinek faunası ve Culex pipiens larvalarının Bacillus cinsi bakterilere karşı duyarlılığı}

\section{The mosquito fauna of Istanbul and susceptibility of Culex pipens larvae to Bacillus spp. bacteriae}

Erdal POLAT ${ }^{1}$, Serdar Mehmet ALTINKUM ${ }^{1}, \quad$ Fadime YILMAZ ${ }^{1}, \quad$ Sema TURAN-UZUNTAŞ ${ }^{1}, \quad$ Yaşar BAĞDATLI ${ }^{2}$

\section{ÖZET}

Amaç: Çalıșmada İstanbul'un sivrisinek faunasını olușturan Culex pipiens larvalarına karșı kullanılan Bacillus cinsi bakterilerin etkisine bakılmıștır.

Yöntemler: Çalıșmada 15 Nisan - 30 Haziran 2013 tarihleri arasında ilaçlama yapılmadan önce İstanbul'un 39 ilçesinde sivrisinek larvalarının geliștiği kaynaklardan 501 örnek alınmıștır. Alınan örnekler laboratuvara getirilmiş, $24^{\circ} \mathrm{C}$ 'de tutularak larvaların III. ve IV evreye gelmesi bir kısmından da erișkin sivrisinek olușması sağlanmıștır. C. pipiens türüne ait III. ve IV. evre larvalara karșı İstanbul Büyükșehir Belediyesi'nin larvasit olarak kullandığı; Bacillus sphaericus (200 g/ ha, $300 \mathrm{~g} /$ ha ve $400 \mathrm{~g} / \mathrm{ha}$ ); Bacillus thuringiensis $\mathrm{H}-14$ ( $200 \mathrm{~g} / \mathrm{ha}, 300 \mathrm{~g} / \mathrm{ha}$ ve $400 \mathrm{~g} / \mathrm{ha}$ ); Bacillus sphaericus (H5a5b, Strain 2362) - Bacillus thuringiensis israelensis (H-14, Strain AM65-52) (5000 g/ha) türlerine ait liyofilize preparatlar kullanılmıștır. Bu liyofilize preparatlardan Unat'ın balıklı buyyon besiyerinde hazırladığımız $\left(6,1 \times 10^{8} \mathrm{CFU} / \mathrm{ml}\right.$ ve $\left.12,6 \times 10^{8} \mathrm{CFU} / \mathrm{ml}\right)$ kültürler kullanılmıștır. Kalan sivrisinek larvaları ve erișkin hale gelen sivrisinekler sterio ve sșık mikroskobunda incelenerek sivrisineklerin türleri belirlenmiștir.

Bulgular: İstanbul'un 39 ilçesinden alınan örneklerin tümünde $C$. pipiens türüne ait larvalara rastlanmıștır. Büyükçekmece, Silivri ve Ümraniye

\section{ABSTRACT}

Objective: In the study the impact of the Bacillus species bacteria used in the fight against larvae of Culex pipiens which constitute mosquito fauna of Istanbul was evaluated.

Methods: In the study, 501 samples were taken from the sources of mosquito larvae before disinfection, in 39 towns of Istanbul, from 15 April to the end of June, in 2013. Samples were brought to the laboratory, by maintaining at $24^{\circ} \mathrm{C}$ to ensure larvae come to stages III and IV, and some of them to adult mosquitoes. Lyophilized preparations of Bacillus sphaericus ( $200 \mathrm{~g} / \mathrm{ha}, 300 \mathrm{~g} / \mathrm{ha}$ and $400 \mathrm{~g} /$ ha); Bacillus thuringiensis $\mathrm{H}-14$ (200 g/ha, $300 \mathrm{~g} / \mathrm{ha}$ and $400 \mathrm{~g} / \mathrm{ha}$ ); Bacillus sphaericus (H5a5b, Strain 2362) - Bacillus thuringiensis israelensis $(\mathrm{H}-14$, Strain AM65-52) (5000 g/ha) species which are used as larvacide by Istanbul Metropolitan Municipality agaist C. pipiens III and IV stage larvae, were used. The cultures $\left(6,1 \times 10^{8} \mathrm{CFU} / \mathrm{ml}\right.$ and $\left.12,6 \times 10^{8} \mathrm{CFU} / \mathrm{ml}\right)$ which prepared from these lyophilized preparations in the medium Unat's fish broth were used. Remaining mosquito larvae and adult mosquitoes were examined under sterio and light microscope to identify the species of mosquitoes.

Results: The larvae of $C$. pipiens species were

${ }^{1}$ İstanbul Üniversitesi, Cerrahpaşa Tıp Fakültesi, Tıbbi Mikrobiyoloji Anabilim Dalı, ISTANBUL

2 İstanbul Üniversitesi, Çevre Yönetim Birimi Koordinatörlüğü, ISTANBUL 
ilçelerinden alınan örneklerde yoğun olarak görülen C. pipiens larvalarının yanı sıra az sayıda Anophel ve Aedes cinsi sivrisineklerin larvalarına da rastlanmıștır. Liyofilize preparatların ve Unat'ın balıklı buyyonun da liyofilize preparatlardan hazırladığımız kültürlerinin $\left(12,6 \times 10^{8} \quad \mathrm{CFU} / \mathrm{ml}\right.$ yoğunluğunun) kullanıldığı deneylerde ilk larva ölümü 50. dakikada bașlamıștır. Kültürlerin $6,1 \times 10^{8} \mathrm{CFU} / \mathrm{ml}$ yoğunluğunun kullanıldığı deneylerde ise ilk larva ölümü 60. dakikada izlenmiștir.

Sonuç: Tüm deneylerde larvaların tamamının 6 . saatte öldüğü görülmüștür. Unat'ın balıklı buyyonunda hazırlanan kültürlerin liyofilize preparatlara göre daha etkili olduğu belirlenmiștir. Kültürdeki bakteri yoğunluğu azaldığında ölümün daha geç bașladığı, ancak larvaların tümünün ölmesi için geçen sürede bir değișikliğin olmadığı tespit edilmiștir.

Anahtar Kelimeler: Culex pipiens, Bacillus sphaericus, Bacillus thuringiensis, Bacillus sphaericus

- Bacillus thuringiensis israelensis, Unat'ın balıklı buyyonu observed in all samples taken from 39 towns of Istanbul. In samples from Buyukcekmece, Silivri and Umraniye districts, beside densely presented C. pipiens larvae, a small amount of Anopheline and Aedes species larvae were also observed. The first larval mortality began in 50th minutes in the experiment with lyophilized preparations and cultures prepared in Unat's fish broth $\left(12,6 \times 10^{8}\right.$ CFU/ml density). In the experiments used culture concentration of $6.1 \times 10^{8} \mathrm{CFU} / \mathrm{ml}$, the first larvae mortality was observed in 60th minute.

Conclusion: In all experiments, it was observed that all of the larvae died in $6^{\text {th }}$ hours. Cultures prepared in Unat's fish broth were determined to be more effective than lyophilized preparations. It was determined that the reduced density of cultures caused a delay in starting time of mortality but overall time for all larvae deaths was unchanged.

Key Words: Culex pipiens, Bacillus sphaericus, Bacillus thuringiensis, Bacillus sphaericus - Bacillus thuringiensis israelensis, Unat's fish broth

\section{GiRiş}

Sivrisinekler tropikal ve subtropikal bölgelerde; göllerin, akarsuların ve bataklıkların çevresinde rüzgarsız, kuytu yerlerde yașarlar. Dișileri geçici dönem ektoparazit olup, genellikle akșamları ve sabahları erken saatlerde sıcakkanlı hayvanlardan ve insanlardan kan emerler. Emdikleri kanın proteinini yumurta oluşturmak için kullanırlar. Sivrisineklerin yumurtlama ve gelișme ortamları açık denizler hariç her türlü su birikintileridir. Anofeller sadece temiz ve berrak sularda geliștiği halde, kuleksler temiz ve kirli her türlü suda gelișebilmektedirler (1-3).

Besin kaynağı kan olan diși sivrisinekler; insandan kan emerken kașıntılı deri lezyonları olușturmaktadırlar. Ayrıca sivrisinekler kan emerken insanlara Plasmodium, filarya ve arbovirüs gibi enfeksiyon etkenlerini de bulaștırmaktadırlar. Bu nedenle sivrisineklerin kontrolü sağlık açısından önem taşımaktadır. Sivrisineklerin kontrolünde; kimyasal, çevre düzenlemesi, mekaniksel-fiziksel, biyolojik vb. çeșitli yöntemler kullanılmaktadır (1-4).

Kimyasal yöntemler: pestisitler (böcekler, kemirgenler, mantarlar ve yabani ot gibi her türlü zararlıya karşı kullanılan maddeler), repellentler (böcek kaçıranlar), atraktanlar (böcek cezbedenler, trikosenez), kemosterilizanlar (böcekleri kısırlaștıranlar)'dır. Böcekleri öldürmek için kullanılan insektisitlere karşı böceklerin geliștirdiği direnç ve bu insektisitlerin insanlar ve çevre üzerindeki zararlı etkileri önemli bir sorundur. Gençlik hormonları ve kısırlaștırma gibi genetik yöntemler de vektör kontrollünde kullanılmaktadır. 
Mekanik ve fiziki yöntemler: yakalama, vurma aletleri, vantilatörler, tuzaklar, yapıșkan maddeler, perde, tel örgü ve cibinliktir. Çevre düzenlemesinde sanitasyon ve durgun su kaynaklarının drenajı önemlidir.

Biyolojik yöntemler: mantarlar (Lagenidum giganteum), protozoonlar (Schistosoma microsporidia), nematodlar (Romanomermis culicivorax), yırtıcı sinekler (Toxorhynchites cinsi), balıklar (Gambusia affinis, Rivulus) ve bakteriler (Bacillus thuringiensis, Bacillus sphaericus) kullanılmaktadır (1-5).

Sivrisineklerin larvalarına karșı kullanılan insektisitlerin ve biyolojik ajanların etkisinin bilinmesi sivrisineklerin kontrolünde büyük öneme sahiptir. Çünkü sivrisinek larvalarının insektistlere karșı direnç geliștirdiği uzun yıllardan beri bilinmektedir (1-2, 6). Hatta yapılan çalıșmalarla sivrisinek larvalarının B. thuringiensis, B. sphaericus'a karșı da direnç geliștirdiği belirlenmiștir (7-9).

İstanbul, Avrupa ile Asya kıtaları arasında köprü görevi gören, 5.712 km²'lik alana kurulmuș bir șehirdir. İstanbul'un 14'ü Anadolu Yakasında, 25'i Avrupa Yakasında olmak üzere toplam 39 ilçesi vardır. Nüfusunun yaklașık \%64,71 (9.162.919)'i Avrupa; \%35,29 (4.997.548)'u da Anadolu yakasında yașamakta olup nüfusu son 20 yılda iki katına çıkmıștır. İșsizlik sebebi ile İstanbul'a göç eden insanlar șehir etrafında gecekondu mahalleleri oluşturmuştur. İstanbul'un bitki örtüsü genellikle maki olup, ormanlık alanı kentin $20 \mathrm{~km}$. kuzeyindeki Belgrad Ormanı'dır. İstanbul'un en büyük akarsuyu, Riva Çayıdır. Boğaza dökülen Küçüksu ve Göksu Dereleri; Haliç'e dökülen Kağıthane ve Alibey dereleri, Küçükçekmece Gölüne dökülen Sazlıdere, Büyükçekmece Gölüne dökülen Karasu Deresi, Terkos Gölüne dökülen Trança deresi, İstanbul'un belli bașlı akarsularıdır. Marmara Denizi kıyısında bulunan Küçükçekmece (11 km²) ve Büyükçekmece $\left(16 \mathrm{~km}^{2}\right)$ göllerinin suları denizle teması olduğu için tuzludur. İstanbul'un yaz ayları genellikle sıcak, kıș ayları fazla soğuk geçmez. Yazkış, gece-gündüz arasında büyük ısı farkları görülmez. İstanbul ve 39 ilçesini gösteren harita Resim 1'de verilmiștir.

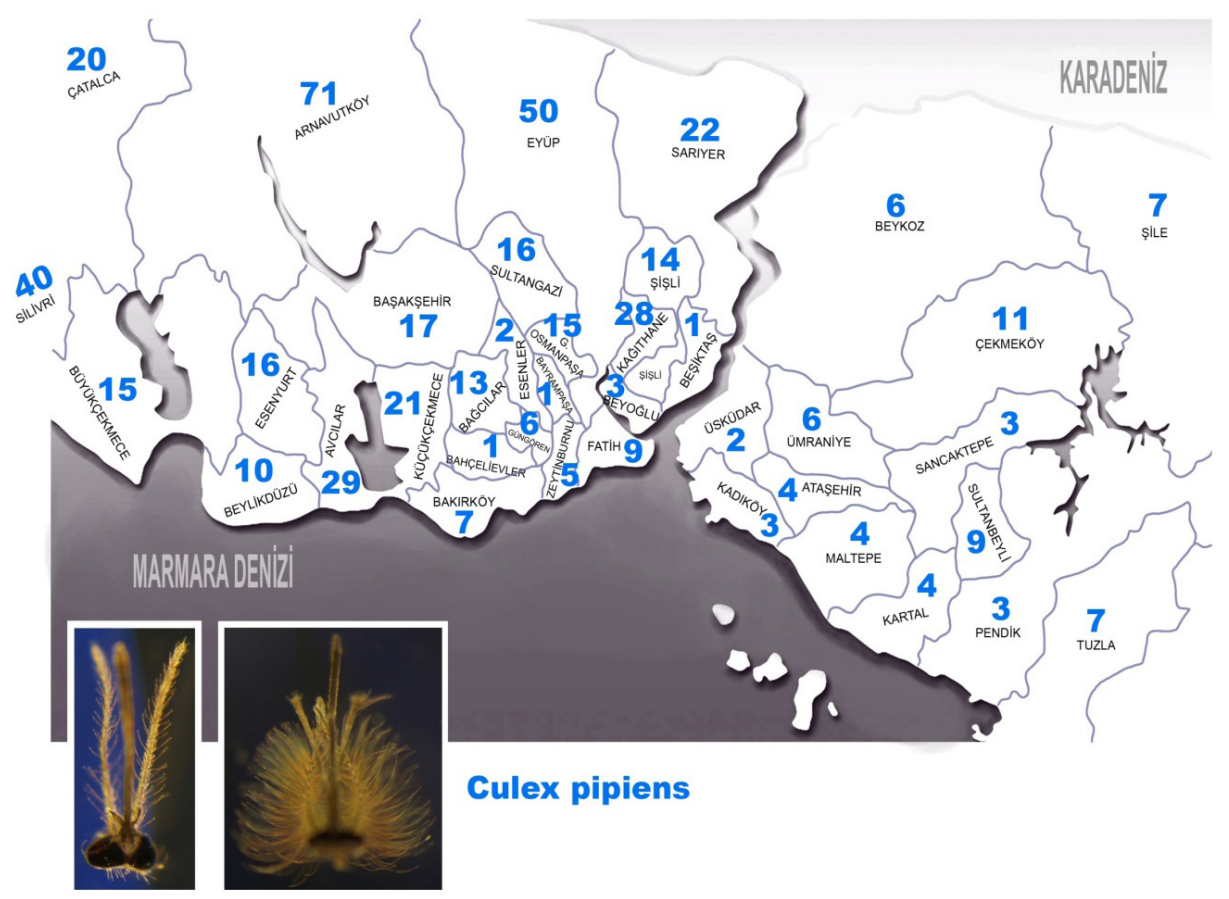

Resim 1. İstanbul'un 39 ilçesinde sivrisinek üreme alanlarından toplanan 501 örneğin ilçelere göre dağılımı, Nisan 2013 
Çalıșmada İstanbul'un sivrisinek faunasını olușturan Culex pipiens larvaları ile mücadelede kullanilan Bacillus cinsi bakterilerin etkisinin araștırılması amaçlanmıștır.

\section{GEREÇ ve YÖNTEM}

İstanbul'un ilçelerinden, 2013 yıllı Nisan ayının ortasında sivrisinek aktivesinin bașlaması ile Haziran ayının sonuna kadar ilaçlama yapılmadan önce sivrisinek larvaları toplanmıștır. Cerrahpașa Tıp Fakültesi Tıbbi Mikrobiyoloji Anabilim Dalı ve İstanbul Büyükșehir Belediyesi Sağlık ve Sosyal Hizmetler Daire Bașkanlığı çalıșanlarınca içinde üredikleri su ile birlikte toplanan larvalar $500 \mathrm{ml}, 1,5$ ve 5 lt'lik pet șișelere konarak laboratuvara getirilmiștir. İstanbul'un 39 ilçesinde sivrisinek larvalarının geliștiği kaynaklardan 501 örnek alınmıștır. Sivrisinek larvalarının alındığı ilçeler ve örnek sayısı Resim 1'de gösterilmiștir.

Laboratuvara getirilen sivrisinek yumurtaları, larvaları ve pupaları $24^{\circ} \mathrm{C}$ 'de tutularak larvaların III. ve IV. evre, pupaların erișkin sivrisineklere dönüșmesi sağlanmıștır. Larvalar ve erișkin sivrisinekler stereomikroskop (Olympus SZX10) ve ișık mikroskop (Zeiss AX10) ile incelenerek tiplendirilmiștir $(1,3,4)$.

B. sphaericus [(H5a5b, Strain 2362) (VectoLex WDG, US)], B. thuringiensis $[(\mathrm{H}-14)$ (VectoBac WDG,US)] ve $B$. sphaericus ( $\mathrm{H} 5 \mathrm{a} 5 \mathrm{~b}$, Strain 2362) - B. thuringiensis israelensis [( $\mathrm{H}-14$, Strain AM6552) (VectoMax G, US)] suşları larvasit olarak kullanılmıștır. Liyofilize Bacillus preparatlarından, içerisinde $100 \mathrm{ml}$ Unat'ın balıklı buyyonu (10) bulunan $250 \mathrm{ml}$ beherlere ekimler yapılmış ve 37 ${ }^{\circ} \mathrm{C}$ 'lik etüvde 48 saat tutulmuștur. Etüvden çıkarılan kültürlerin konsantrasyonu BD Phoenix cihazı ile nefelometrik yöntemle ölçülerek 2 McFarland (MF) $\left(6,1 \times 10^{8} \mathrm{CFU} / \mathrm{ml}\right)$ ve $4 \mathrm{MF}\left(12,6 \times 10^{8} \mathrm{CFU} / \mathrm{ml}\right)$ bakteri bulunacak șekilde ayarlanmıștır.

C. pipiens türüne ait III. ve IV. evre larvalar, içerisinde $250 \mathrm{cc}$ su bulunan $(\mathrm{pH}=7 \pm 02$ olan 48 saat dinlendirilmiș musluk suyu) kaplara süzgeç ile 100 adet olarak aktarılmıștır. B. sphaericus'un $200 \mathrm{~g} /$ ha, $300 \mathrm{~g} / \mathrm{ha}$ ve $400 \mathrm{~g} / \mathrm{ha} ; \quad B$. thuringiensis $\mathrm{H}-14$ $200 \mathrm{~g} / \mathrm{ha}, 300 \mathrm{~g} / \mathrm{ha}$ ve $400 \mathrm{~g} / \mathrm{ha} ; B$. sphaericus (H5a5b, Strain 2362) - B. thuringiensis israelensis (H-14, Strain AM65-52) karıșımının 5.000 g/ha'lık, kültürlerin ise $6,1 \times 10^{8} \mathrm{CFU} / \mathrm{ml}$ ve $12,6 \times 10^{8} \mathrm{CFU} /$ ml konsantrasyonları kullanılmıștır. Aynı zamanda her deney için bir kapta 100 adet larva kontrol için bulundurulmuștur. 24 saat etki süresinde larvaların ölü ve canlı olanları sayılmıștır. Deneyler oda ısısında $\left(24^{\circ} \mathrm{C}\right)$ yapılmıștır $(11,12)$.

\section{BULGULAR}

İstanbul'un 39 ilçesinden sivrisinek larvalarının geliștiği 501 kaynaktan alınan örneklerden sadece Büyükçekmece, Silivri ve Ümraniye ilçelerinde Anophel ve Aedes cinsi sivrisineklerin larvaları görülmüștür. İstanbul'un tüm ilçelerinde ise $C$. pipiens türü sivrisinek larvalarına rastlanmıștır (Resim 2).

Bacillus liyofilize preparatları ve kültürlerinin $12,6 \times 10^{8} \mathrm{CFU} / \mathrm{ml}$ konsantrasyonlarda kullanıldığı

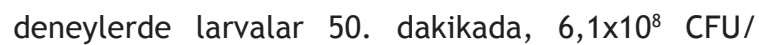
ml'lik konsantrasyonunda kullanıldığı deneylerde ise 60. dakikada ölmeye bașlamıștır.

50. dakikada $B$. sphaericus'un 4 MF öldürme oranı, $400 \mathrm{~g} /$ ha'dan daha yüksektir (\%20 - \%14). B. thuringiensis'in ki ise $300 \mathrm{~g} / \mathrm{ha}$ ve $400 \mathrm{~g} / \mathrm{ha}$ 'dan daha düşük ancak $200 \mathrm{~g} /$ ha ile aynıdır (\%20). B. sphaericus - B. thuringiensis karışımı 4 MF öldürme oranı, 5.000 $\mathrm{g} /$ ha konsantrasyonundan daha fazladır (\%42 - \%40).

Liyofilize praparatlardan 50. dakikada öldürme oranı en yüksek olanı B. sphaericus - $B$. thuringiensis israelensis $5.000 \mathrm{~g} / \mathrm{ha}$ karıșımıdır. Bu karıșım kullanıldığında larvaların toplu halde öldüğü görülmüștür. Larvalarda ölümün bașlangıç - bitiș süresinde değișiklik olmadığı tespit edilmiștir. Değișik yoğunlukta kullanılan biyolojik ajanların larvaların tamamını 6. saatte öldürdüğü tespit edilmiștir. Çalıșmamızda elde ettiğimiz bulgular Tablo 1' de özetlenmiștir. 

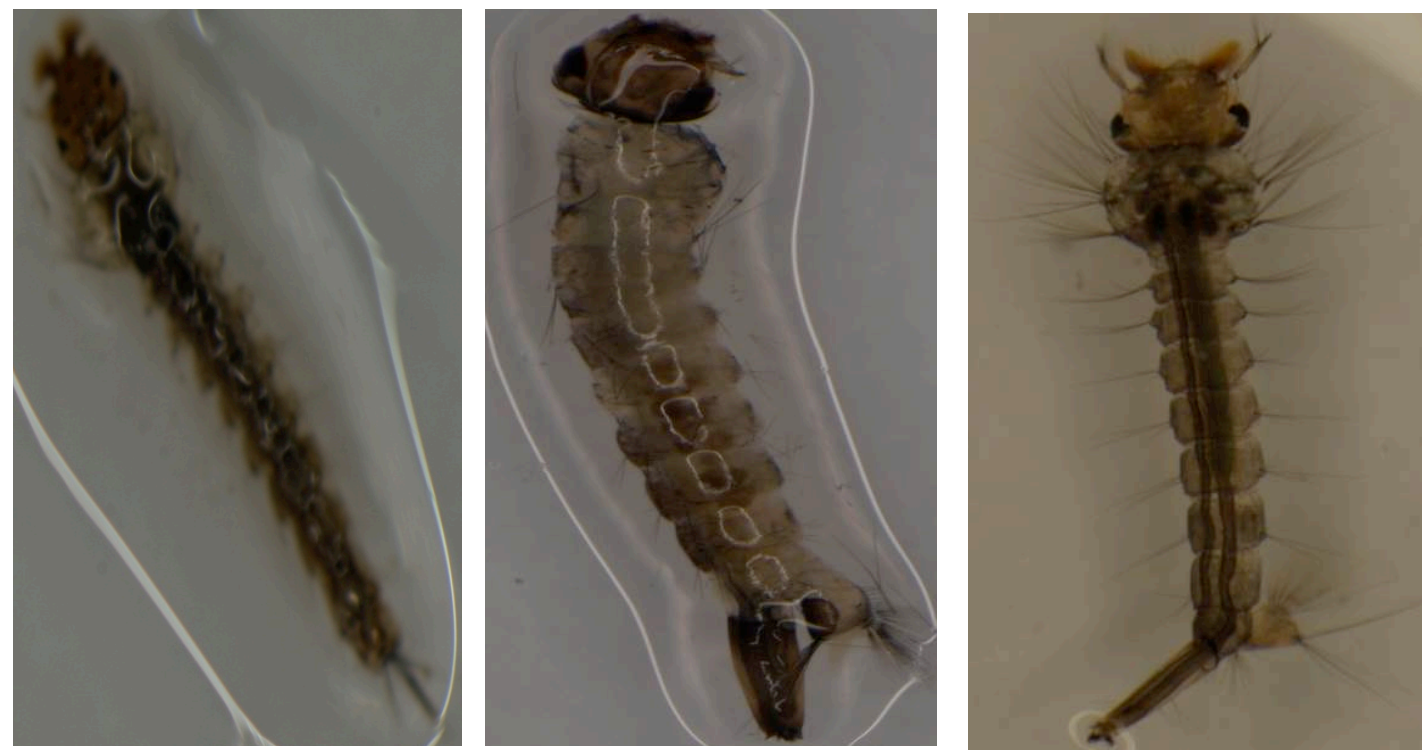

Resim 2. İstanbul'un 39 ilçesinde sivrisinek üreme alanlarından toplanan Anophel (a), Aedes (b), Culex (c) larvaları görünümleri, Nisan 2013

Tablo 1. İstanbul'un 39 ilçesinden toplanan Culex larvalarına karșı larvasit olarak kullanılan farklı Bacillus türlerinin etkileri, Nisan 2013

\begin{tabular}{|c|c|c|c|c|c|}
\hline \multirow{2}{*}{ Larvasitler } & \multirow{2}{*}{$\begin{array}{l}\text { Kullanilan } \\
\text { Oranlar }\end{array}$} & \multirow{2}{*}{$\begin{array}{c}\text { Canlı Larva Sayısı } \\
\text { Başlangıç }\end{array}$} & \multicolumn{3}{|c|}{ Ölü Larva Sayısı } \\
\hline & & & 50. dak & 60. dak & 6. saat \\
\hline \multirow{5}{*}{ B. sphaericus } & $200 \mathrm{~g} / \mathrm{ha}$ & 100 & 8 & 8 & 100 \\
\hline & $300 \mathrm{~g} / \mathrm{ha}$ & 100 & 10 & 10 & 100 \\
\hline & $400 \mathrm{~g} / \mathrm{ha}$ & 100 & 14 & 14 & 100 \\
\hline & $2 \mathrm{MF}$ CFU $/ \mathrm{ml}$ & 100 & 0 & 20 & 100 \\
\hline & $4 \mathrm{MF} \mathrm{CFU/ml}$ & 100 & 20 & 20 & 100 \\
\hline \multirow{5}{*}{ B. thuringiensis } & $200 \mathrm{~g} / \mathrm{ha}$ & 100 & 20 & 20 & 100 \\
\hline & $300 \mathrm{~g} / \mathrm{ha}$ & 100 & 30 & 30 & 100 \\
\hline & $400 \mathrm{~g} / \mathrm{ha}$ & 100 & 40 & 40 & 100 \\
\hline & $2 \mathrm{MF}$ CFU/ml & 100 & 0 & 20 & 100 \\
\hline & $4 \mathrm{MF}$ CFU/ml & 100 & 20 & 20 & 100 \\
\hline \multirow{3}{*}{ B. sphaericus + B. thuringiensis } & $5000 \mathrm{~g} / \mathrm{ha}$ & 100 & 40 & 40 & 100 \\
\hline & $2 \mathrm{MF}$ CFU/ml & 100 & 0 & 10 & 100 \\
\hline & $4 \mathrm{MF} \mathrm{CFU/ml}$ & 100 & 42 & 42 & 100 \\
\hline
\end{tabular}

\section{TARTIŞMA}

Gelișmekte olan ülkelerde pestisitlerin en az \%90' 1 tarım alanında, \%10'u kadarı da vektörlerin kontrollünde kullanılmaktadır. Bu da insan sağlığı ve çevre açısından tehlike olușturmaktadır. Çeșitli ülkelerde ihtiyaçtan fazla üretilen pestisitlerin stokları, üretiminden daha zor ve pahalıya mal olmaktadır. Bunun doğal sonucu olarak da nehirler, körfezler, toprak ve su kaynakları uzun süreli kirlenmekte; suda yașayan canlıları ve karada yașayan 
böcekleri, kușları ve toprağın mikrofilorasını etkileyerek ekolojik dengeyi bozmaktadır. Bu canlılar nesillerini sürdürebilmek için pestisitlere karşı direnç geliștirirler. Günümüzde insektisitlere karşı direnç her tür vektörde az çok görülmektedir. Direncin yaygınlașmasında tarımda büyük oranda kullanılan pestisitlerin etkisi vardır. Sivrisineklerin insektisitlere karșı direnci larva, erișkin veya her iki evrede de olabilir. Larva evresinde direnç genellikle tarımda kullanılan pestisitlerden, erișkin evresindeki direnç ise erișkin sivrisinek mücadelesinde kullanılan aerosollerden kaynaklanmaktadır. Sivrisinekler; dichlorodiphenyl trichloroethane (DDT), dieldrin, benzen hekzaklorür $(\mathrm{BCH})$ gibi organik klorlu insektisitlere, organik fosforlu ve karbamatl insektisitlere çoklu direnç olușturabilmektedirler. Dünya Sağlık Örgütü'nün 1980 yılında yayımladığı raporda halk sağlığında ve veterinerlikte öneme sahip 51 anofel, 42 kuleks cinsinin bir veya daha fazla insektisite karșı dirençli olduğunu belirtmiștir (13). Bunlardan dolayı bir insektisit alınmadan önce kullanılacağı bölgedeki sineklere karșı etkili olup olmadığına bakılmalıdır.

Sivrisinek mücadelesinde insektisitler yanı sıra biyolojik yöntemler de yaygın olarak kullanılmaktadır. İstanbul'da sivrisinek larvalarının mücadelesinde biyolojikolarak; Gambusia affinis türübalıklar ve Bacillus cinsi bakteriler yaygın bir șekilde kullanılmaktadır. Sivrisinek larvalarının kontrolünde kullanılan $B$. thuringiensis ve $B$. sphaericus sporlu bakteriler olup güçlü toksin oluşturan türlerdir. Mide zehri olan toksinler sadece larvalar tarafından yutulduklarında etkili olup; pupa, erișkin ve yumurtalara etkisizdirler (1, 2, 5-9).

Unat ve ark. 1994 yılında İstanbul'un Altınșehir, Halkalı ve Yedikule bölgelerinden topladıkları sivrisinek larvalarının C. pipiens molestus (Farks) türüne ait olduğunu belirtmişlerdir. Bu çalıșmada özelikle anofel türü sivrisineklerin larvaları ve erișkinleri araștırılmıș ancak Beykoz ve Çatalca ilçelerinde Karadenize yakın Karaca Köy, Kıуı Köy ve Riva bölgesinde tespit etmișlerdir. Bu çalıșmada da Anophel ve Aedes cinsi sivrisineklere; Büyükçekmece, Silivri ve Ümraniye ilçelerinde rastlanmıștır (11).
İstanbul'un coğrafik yapısı ve iklim koșulları sivrisineklerin üremesi için uygundur. Ancak İstanbul'un 39 ilçesinden sivrisinek larvalarının geliștiği kaynaklardan alınan 501 örnekten sadece Büyükçekmece, Silivri ve Ümraniye ilçelerine ait örneklerde Anophel ve Aedes cinsi sivrisineklerin larvaları görülmüştür. Anofel cinsi sivrisineğin larvaları genellikle organik madde bulunmayan temiz, berrak ve durgun sularda gelișir. İstanbul'da bulunan temiz durgun sular aşırı, düzensiz yapılașma ve artan nüfus yüzünden hızla kirlenmekte ve yok olmaktadır. İstanbul'un tüm ilçelerinde ise her türlü durgun suda üreyen $C$. pipiens türü sivrisinek larvalarına baskın olarak rastlanmıștır (Resim 2).

Çalıșmamızda, C. pipiens türüne ait III. ve IV. evre larvalarına karșı B. sphaericus (H5a5b, Strain 2362), B. thuringiensis israelensis $(\mathrm{H}-14$, Strain AM65-52) ile $B$. sphaericus - B. thuringiensis kombinasyonu preparatlarının ve bu preparatların $4 \mathrm{MF}\left(12,6 \times 10^{8}\right.$ $\mathrm{CFU} / \mathrm{ml}$ ) konsantrasyondaki kültürlerinin etkili olduğu bulunmuștur. Bacillus 4 MF konsantrasyondaki kültürlerinin liyofilize preparatlardan daha etkili olduğu görülmüștür. Bunun nedeninin; liyofilizasyon ișlemi esnasında bakterilerin bir kısmının canlılığını kaybetmesinden kaynaklandığını düşünmekteyiz. Oysa bakteriler 48-72 saatlik kültürlerde canlılığını pek kaybetmezler. $B$. sphaericus ve $B$. thuringiensis $\mathrm{H}-14$ içeren kültürde üreyen bakteri yoğunluğu azaldığında ölümün daha geç bașladığı, ancak larvaların tümünün ölmesi için geçen sürede bir değişikliğin olmadığı tespit edilmiștir. Unat ve ark. 1994 yılında İstanbul'un Altınșehir, Halkalı ve Yedikule Bölgelerinden, Edirne'nin Enez Illçesi'nden toplanan C. pipiens molestus (Farks) larvaları ile yaptıkları iki farklı çalıșmada; ABATE (Temephos), ACTELLiC (Primiphos methyl) ve malathion'un C. pipiens molestus (Farks) larvalarına karșı \%100 etkili olduğunu bulmușlardır $(11,12)$. Yaptığımız literatür taramalarına göre Unat ve ark.'nın bu çalıșmalarından sonra İstanbul'da insektisitlerle ilgili yapılan herhangi bir çalıșmaya rastlanmamıștır.

Aldemir ve ark. 2005 yılında yaptıkları çalıșmalarda Tambro $^{\circledR} 500$ EC (518 g/l temephos) ve Ekolarv ${ }^{\circledR} 500$ EC 
( $500 \mathrm{~g} / \mathrm{l}$ temephos) laboratuvarda ve Ankara'nın Gölbașı illçesi, Mogan Gölü doğal habitatında $A$. sachoravi ve Culex pipiens larvalarına karșı etkili bulmuşlardır (14).

Akıner ve ark. yaptıkları çalıșmalarda 2007 yılında malathion and propoxur için tüm $A$. maculipennis popülasyonları ölüm oranlarının șüpheli direnç kategorisinde yer aldığını ortaya koymuşlardır. 2008 yılında Trakya Bölgesi popülasyonları (Avanoz, Tatarköy, Dereköy) șüpheli direnç kategorisinde yer alırken Birecik, Beyșehir ve Çankırı popülasyonlarının dirençsiz kategoride olduğunu belirtmişlerdir (6).

Bursalı ve ark. (2013), Aydın, Burdur, Muğla, Isparta ve İzmir'den toplanan $A$. maculipennis kompleksi popülasyonlarında DDT (\%4)'yi \%64,6, deltametrin $(\% 0,025)$ 'i \%90,4 ve permetrin $(\% 0,75)$ 'i $\% 74,8$ etkili olarak bulmuşlardır. Kdr (knock-down resistance) mutasyonla 97 örneğin Aydın ve Burdur'da sadece birer adet $A$. sacharovi' de kdr direnci saptamışlardır (15).

Ulașabildiğimiz kaynaklara göre ülkemizde sivrisineklerdeki direnç ile ilgili çalışmalar $(6,11,12$, $14,15)$ genellikle insektisitler kullanılarak yapılmıștır. Bu çalıșmaların bazılarında sivrisineklerin insektisitlere karşı direnç geliștirdiği ortaya konmuştur. Ancak İstanbul'da biyolojik ajanlar ile de yapılan herhangi bir çalıșmaya rastlanmamıștır. Oysa günümüzde İstanbul'da sivrisineklerin larvaları ile mücadelede genellikle Gambusia affinis türü balıklar ve $B$. thuringiensis ve $B$. sphaericus türü sporlu bakteriler gibi biyolojik yöntemler kullanılmaktadır. Ancak bu bakterilere karșı sivrisinek larvalarının bir direnç olușturup olușturmadığı bilinmemektedir. Yaptığımız çalıșmada $B$. sphaericus, $B$. thuringiensis, $B$. sphaericus - $B$. thuringiensis israelensis bakterileri kombinasyonu C. pipiens türüne ait III. ve IV. evre larvalarına karșı etkili bulunmuștur.
Leroux ve ark. (1997) B. sphaericus'a karșı C. pipiens larvalarının değişik direnç mekanizmalarını çalıșmıștır (7). Nielsen-LeRoux ve ark. (2001) B. sphaericus Strain 2362 karşı C. pipiens larvalarının geliștirdiği değișik çapraz direnç seviyelerini ortaya koymuşlardır (8). Sun ve ark. 2001 yılında yaptıkları çalıșmalara göre $C$. pipiens larvalarının $B$. sphaericus ve $B$. thuringiensis israelensis toksinlerine karșı direnç geliştirdiklerini bildirmişlerdir (9). Bundan dolayı sivrisinek larvaları ile mücadelede sporlu bakteriler kullanılsa bile, bu bakteriler alınmadan ve kullanılmadan önce mutlaka sivrisinek larvalarının bu ajanlara karșı direncinin olup olmadığı test edilmiștir.

Biyolojikkontrol, vektörmücadelesindetamamlayıcı ve ekonomik bir bölümü olușturmaktadır. Sivrisinek larvaları ile mücadelede kullanılan $B$. sphaericus ve $B$. thuringiensis bakterilerini dıșarıdan satın almak yerine Unat'ın tarif etiği balıklı besiyerinde üretilerek daha da ekonomik hale getirilebilir. Çalıșmamızda da Bacillus kültürleriyle elde edilen sonuçların liyofilize sonuçlarla benzer hatta daha iyi olduğu tespit edilmiștir.

Hedef dıșı canlılar için nispeten güvenilir olușu biyolojik yöntemleri değerli kılmaktadır. Biyolojik kontrol temel olarak bu tabii düzenleyici sistemin insanın lehine manipülasyonundan ibarettir.

Sonuç olarak ülkemizde sivrisinek larvalarının kontrolünde kullanılan biyolojik ajanlar ile ilgili herhangi bir çalıșmaya rastlanmamıștır. Oysa yurt dıșında yapılan çalıșmalarda biyolojik ajanlara karșı direnç varlığı gösterilmiştir. Bundan dolayı ülkemizde sivrisineklerin larvaları ile mücadelede kullanılan B. sphaericus ve $B$. thuringiensis'e karșı direncin olup olmadığının daha geniș çalıșmalar ile araștırılması gerektiğini düşünmekteyiz.

\section{TEŞEKKÜR}

İstanbul Büyükșehir Belediyesi Sağlık ve Sosyal Hizmetler Daire Başkanlığı çalışanlarına verdikleri destek ve ișbirliği için teșekkür ederiz.

\section{ÇIKAR ÇATIȘMASI}

Yazarlar herhangi bir çıkar çatıșması bildirmemektedir. 


\section{KAYNAKLAR}

1. Unat EK, Samastı M. (Unat EK, Yücel A, Altaș K, Samastı M). Unat'ın Tıp Parazitolojisi, İnsanın Ökaryonlu Parazitleri ve Bunlarla Olușan Hastalıkları. V. baskı, Cerrahpașa Tıp Fak. Vakfı yayınları, 1995; 15: 140-57.

2. Daldal N, Atambay M. Sivrisinekler Familya Culicidae Stephens, 1829). Özcel M, Özbel Y, Ak M. Editörler. Özcel'in Tıbbi Parazit Hastalıkları. İzmir, 2007; 811-5.

3. Merdivenci A. Türkiye Sivrisinekleri. İstanbul Üniversitesi Cerrahpașa Tıp Fakültesi Yayınları. 1984.

4. Merdivenci A. Medikal Entomoloji. 3. Baskı. İstanbul Üniversitesi Cerrahpașa Tıp Fakültesi Yayınları, $1981 ; 81-116$.

5. Yarsan E. Vektör mücadelesinde biyopestisitler. Turk Hij Den Biyol Derg, 2007; 64(1): 61-70.

6. Akıner MM. Malathion and propoxur resistance in Turkish populations of the Anopheles maculipennis (Diptera: Culicidae) and relation to the insensitive acetylcholinesterase. Türk Parazitol Derg, 2014; 18: 111-5.

7. Leroux CN, Pasquier F, Charles JF, Sinerge G, Gaven $B$, Pasteur N. Resistance to Bacillus sphaericus involves different mechanisms in Culex pipiens (Diptera: Culicidae) larvae. J Med Entomol, 1997; 34(3): 321-7.

8. Nielsen-LeRoux C, Rao DR, Murphy JR, Carron A, Mani TR, Hamon S, Mulla MS. Various Levels of CrossResistance to Bacillus sphaericus Strains in Culex pipiens (Diptera: Culicidae) Colonies Resistant to B. sphaericus Strain 2362. Appl Environ Microbiol, 2001; 67(11): 5049-54.
9. Sun F, Yuan Z, Li T, Zhang Y, Yu J, Pang Yi. Reduction of resistance of Culex pipiens larvae to the binary toxin from Bacillus sphaericus by coexpression of cry4Ba from Bacillus thuringiensis subsp. israelensis with the binary toxin gene. World $\mathrm{J}$ Microbiol Biotech, 2001; 17: 385-9.

10. Unat EK. Tıp Bakteriyolojisi ve Virolojisi Cilt 1, II. Baskı. Dergah Yayınları, İstanbul, 1986: 75-6.

11. Unat EK, Çalıșır B, Polat E. İstanbul'un Altınşehir, Halkalı ve Yedikule bölgelerinden toplanan Culex pipiens molestus (Farks) larvalarının kullanılmakta olan insektisidlere karșı duyarlılığı. Türk Parazitol Derg, 1994; 18(4): 503-6.

12. Unat EK, Çalıșır B, Polat E. Enez bölgesinden toplanan Culex pipiens molestus (Farks) larvalarının kullanılmakta olan insektisidlere karșı duyarlılığı. Türk Parazitol Derg, 1994; 18(4): 507-10.

13. http://www. saglik.gov.tr/TR/dosya/1-73090/h/ turreporttur.pdf [cited 2015 Aralık 524].

14. Aldemir A, Ege M. Temephos aktif maddeli iki insektisitin sivrisinek (Diptera: Culicidae) larvaları üzerindeki etkinlik ve kalıcılığı. Türk Parazitol Derg, 2005; 29(2): 126-30.

15. Bursalı F, Şimșek FM. Anopheles maculipennis kompleksi populasyonlarında DDT, deltametrin ve permetrin insektisitlerine karșı direnç düzeyi ve $\mathrm{kdr}$ (knock-down resistance) mutasyonuyla ilișkisi. 18. Ulusal Parazitol Kong, Denizli, 2013; 139-40. 


\title{
Fascioliasis tanısında hekimlerde ERCP yerine serolojik test farkındalığı yaratmak: Olgu sunumu
}

\section{To create awareness of serological tests instead of ERCP for fascioliasis diagnosis among physicians: A case report}

\author{
Ayşegül AKSOY-GÖKMEN'1, Bayram PEKTAŞ ${ }^{1}, \quad$ Mehmet $\mathrm{CAMCl}^{2}$, Celal BUĞDACI${ }^{1}$, \\ Erkan YULA ${ }^{1}, \quad$ Selçuk KAYA ${ }^{1}, \quad$ Mustafa DEMiRCi ${ }^{1}$
}

\begin{abstract}
ÖZET
Fascioliasis, insanda nadir rastlanan karaciğer ve safra yolu hastalığıdır. Fasciola hepatica metaserkarya içeren su bitkilerinin yenmesi veya kontamine suların içilmesi ile bulașmaktadır. Fascioliasis tanısında, dıșkıda parazit yumurtasının saptanması esas iken serolojik ve radyolojik testler de önemli yer tutmaktadır. Yetmiş beș yașında bir hasta, bir aydır karın ağrısı bulantı kusma iștahsızlık şikayetiyle kliniğimize bașvurdu. Bir yıl öncesinde kolesistektomi hikayesi olan hastanın \%8 eoziofilisi dışında rutin biyokimyasal parametreleri normaldi. Koledokta taş olup olmadığını görmek ve karın ağrısı etiyolojisini ortaya koymak için endoskopik ultrasonografi planlandı. Hastanın koledok kanalında parazitle uyumlu görüntü olması üzerine tanı ve tedavi amaçlı endoskopik retrograt kolanjiopankreatografi (ERCP) yapıldı. ERCP ile koledok kanalından iki adet F. hepatica'yla uyumlu parazit çıkartıldı. Postoperatif, iki doz $10 \mathrm{mg} / \mathrm{kg}$ triklabendazol kullanan hastanın, iki hafta sonra yapılan kontrol muayenesinde şikayetlerinin tamamen geçtiği gözlendi. Girișimsel yolla tanı ve tedavisini uyguladığımız fascioliasise bağlı bir akut kolanjit vakası ve bununla ilgili literatürün gözden geçirilmesini sunuyoruz.
\end{abstract}

Anahtar Kelimeler: Fascioliasis, endoskopik retrograt kolanjiopankreotografi (ERCP)

\section{ABSTRACT}

Fascioliasis is a liver and biliary tract disease, which is rare in human. It is transmitted by consuming water plants containing Fasciola hepatica metacercariae or drinking contaminated water. Detection of parasite eggs in stool and serological/radiological tests are significant in fascioliasis diagnosis. A female patient who is 75-years-old applied to our clinic with one month duration of abdominal pain, nausea, vomit and anorexia. Routine biochemistry parameters of the patients with cholecystectomy were normal except her $8 \%$ eosinophilia. Endoscopic ultrasonography was planned in order to determine abdominal pain etiology and if there was a stone in ductus choledochus. Endoscopic retrograde cholangiopancreatography (ERCP) was applied for diagnosis and treatment purpose after the view of parasitecompatible view in ductus choledochus of the patient. Two parasites compatible with $F$. hepatica were taken out of ductus choledochus by ERCP. It was observed that the complaints of the patient, who was postoperatively treated with two doses of $10 \mathrm{mg} / \mathrm{kg}$ triclabendazole, was completely passed in control examination after two weeks. We present an acute cholangitis case depends on fascioliasis that we interventional diagnosed and treated, and the review of literatures on this case.

Key Words: Fascioliasis, endoscopic retrograde cholangiopancreatography (ERCP)

\footnotetext{
1 İzmir Katip Çelebi Üniversitesi, Tıp Fakültesi, Atatürk Eğitim Araştırma Hastanesi, Mikrobiyoloji Bölümü, IZMiR

${ }^{2}$ İzmir Bozyaka Eğitim Araştırma Hastanesi, Gastroenteroloji Bölümü, IZMIR
}

İletişim/Corresponding Author: Ayşegül AKSOY-GÖKMEN

İzmir Katip Çelebi Üniversitesi, Tip Fakültesi, Atatürk Eğitim Araştrma Hastanesi, Mikrobiyoloji Bölümü, IZMiR

Tel : +905063592016_ E-posta/E-mail : aaksoygokmen@hotmail.com

Geliş Tarihi / Received : 12.11 .2015

Kabul Tarihi/Accepted : 22.12 .2015

DOI ID : 10.5505/TurkHijyen.2016.93196

Aksoy-Gökmen A, Pektaș B, Camcı M, Buğdacı C, Yula, Kaya S, Demirci M. Fascioliasis tanısında hekimlerde ERCP yerine serolojik test farkındalığı yaratmak: Olgu sunumu. Turk Hij Den Biyol Derg, 2016; 73(2): 157-60. 


\section{Giriș}

Fascioliasis insanda nadir rastlanan karaciğer ve safra yolu hastalığıdır. Fasciola hepatica metaserkarya içeren su bitkilerinin yenmesi veya kontamine suların içilmesi ile bulașmaktadır (1). Bağırsaklardan periton yoluyla karaciğere göç eden jüvenil parazitler safra yollarında erișkin hale geçer. Akut enfeksiyonda (karaciğer dönemi) ateș, hepatomegali, karın ağrısı, kilo kaybı, anemi ve eozinofili görülür. Kronik olgularda (safra kanalı dönemi) tıkanma sarılığı ve kolanjit hatta siroza kadar giden tablolara rastlanabilir. Kliniğinin nonspesifik olması, ayrıca nadir görülen hastalık olmasından dolayı tanıda akla gelmemesiyle sık atlanan hastalıklar grubundadır ve bu nedenle de tanı zorlașır (2). Fascioliasis tanısında, dıșkıda parazit yumurtasının saptanması ve serolojik testler önemli yer tutmaktadır. Radyolojik testler arasında girișimsel olmayan ultrasonografi (USG), bilgisayarlı tomografi (BT) tanıda yol göstericidir. Bununla birlikte hem tanı hem de tedavi olanağı sağlayabilen manyetik rezonans kolanjiopankreatografi (MRCP), endoskopik ultrasonografi (EUS), endoskopik retrograt kolanjiopankreatografi (ERCP) gibi yöntemler de tanıda kullanılabilir (3). Özellikle serolojik testlerin kullanılmadığı olgularda, ERCP ile erişkinlerin gösterilmesi ülkemizde hala en yaygın tanı yöntemlerinden birisidir (1-4). Bu olgu sunumunda; karın ağrısı, ateș ve eozinofilisi olan olgularda $F$. hepatica'nın akılda tutulmasına; bu hastalarda invaziv bir ișlem olan ERCP yerine serolojik yöntemler (IHA veya ELISA) ile fascioliasis tanısı konulabileceğine ve pozitifliği durumunda triklabendazol ile tedavi sağlanabileceğine dikkat çekmek amaçlanmıştır.

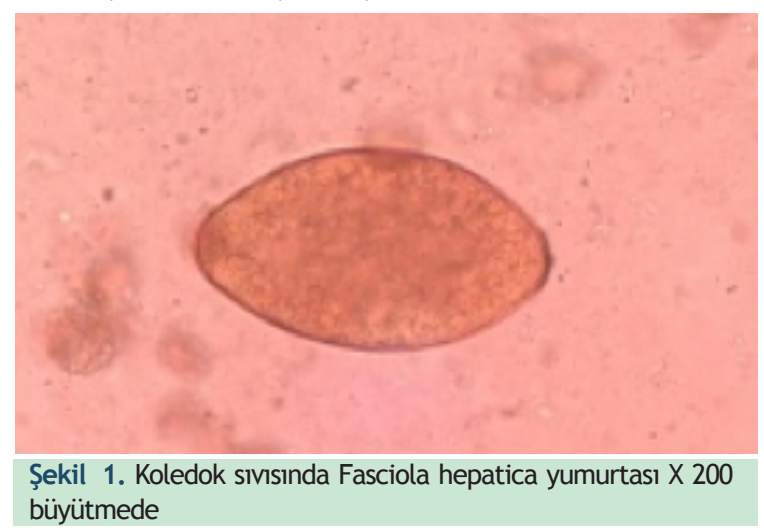

\section{OLGU SUNUMU}

Yetmiș beș yașında Van'da ikamet eden kadın hasta bir aydır karın ağrısı, bulantı, kusma, iștahsızlık șikayetiyle İzmir Katip Çelebi Üniversitesi Atatürk Eğitim Araștırma Hastanesi Gastroenteroloji Polikliniğine bașvurdu. Hastanın özgeçmișinde bir yıl önce dıș merkezde kolesistektomi operasyonu dıșında herhangi bir özellik yoktu. Hemogramında \%8 eozinofilisi olan hastanın rutin biyokimyası normaldi. Hastanın epikrizinde kolesistektomi olduğu fakat intrahepatik ve koledok kanallarının bırakıldığı belirtiliyordu. Bir ay önce karın ağrısı nedeniyle diș merkeze giden hastanın yapılan USG'sinde intrahepatik ve koledok kanalının genişlediği ve taș șüphesi olduğu söylenmiș. Bunun üzerine hastanemiz Gastroenteroloji Polikliniğine bașvuran hastaya koledokta taș olup olmadığını görmek ve karın ağrısı etiyolojisini belirlemek için EUS planlandı. Hastanın koledok kanalında parazitle uyumlu görüntü olması üzerine tanı ve tedavi amaçlı ERCP yapıldı. ERCP ile sfinkterotomi ve balonla koledok kanalından iki adet F. hepatica'yla uyumlu parazit çıkartıldı. Parazitoloji laboratuvarına gönderilen koledok sıvısı ve erișkin parazit $F$. hepatica erișkini ve yumurtası olarak rapor edildi (Şekil 1, 2). Triklabendazol tedavisi $10 \mathrm{mg} / \mathrm{kg}$ gün tek doz verildi ve ilacın iki gün sonra tekrarlanması söylenerek hasta taburcu edildi.

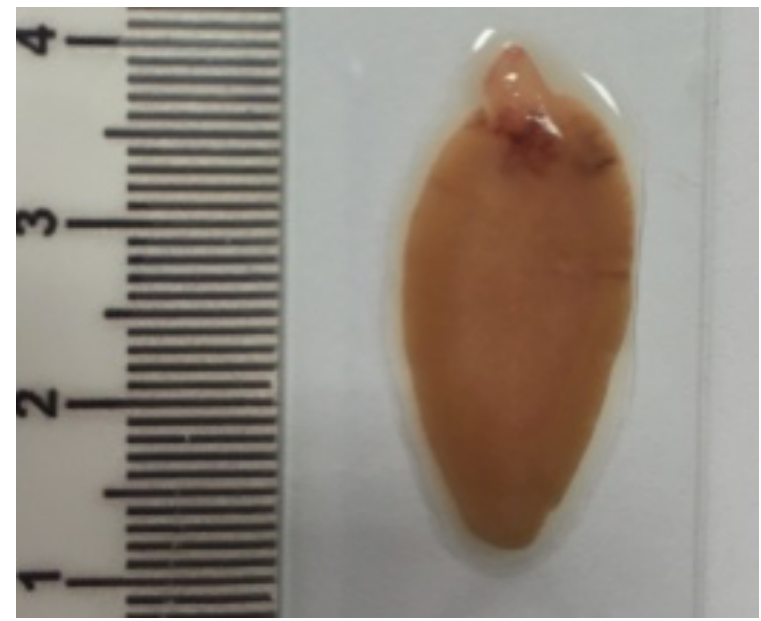

Şekil 2. ERCP ile çıkarılan Fasciola hepatica erișkin formu 
İki hafta sonra yapılan kontrol muayenesinde hastanın șikayetlerinin tamamen düzeldiği görüldü.

\section{TARTIŞMA}

Fascioliasis dünyada 2,4 milyon insanı etkileyen ve 180 milyon insanın risk altında olduğu zoonotik bir hastalıktır (3). Dünyada Afrika, Batı Avrupa ve Latin Amerika'da sık gözlenirken ülkemizde Doğu ve Güneydoğu Anadolu Bölgesi, Akdeniz ve Göller Bölgesinde olduğu bildirilmiștir $(2,3)$. Ülkemizdeki sıklığı \%1'in altında bildirilmesine karșın, Doğu Anadolu'da yapılan bir seroprevalans çalıșmasında $\% 2,78$ olarak bulunmuștur $(3,4)$. Demirci ve ark.'larının (5) Isparta bölgesinde yaptığı çalıșmada F. hepatica seroprevalansı eozinofilik grupta $\% 6,1$ iken non-eozinofilik kontrol grubunda $\% 0,9$ olarak bulunmuştur.

Fascioliasis kliniğinin özgül olmayan bulgular içermesi tanıdaki zorluklardan birisidir. Klasik hastalık triadı olarak bilinen karın ağrısı, ateș ve eozinofili hastalarda değişkenlik gösterebilmektedir. Hastalığın üç klinik fazı bulunmaktadır. Hepatik faz, latent faz ve safra yollarına yerleșerek kolestaz ve kolanjit bulgularının geliștiği kronik fazdır (6). Bu nedenle karın ağrısı, ateș ve eozinofilisi olan hastalarda özellikle de endemik bölgede yaşıyorsa fascioliasis akla getirilmeli, akut fazda hastalık teșhis edilip kolanjit ve kolestaz gibi komplikasyonların önüne geçilmelidir (2).

Karın ağrısı ve eozinofili șikayeti ile hastanemize başvuran bu hastaya tanı ve tedavi amaçlı EUS'ta parazitten șüphelenilmesi üzerine bilier obstrüksiyon olmadığı halde, ileri bir merkez olmamız, rutinde sıklıkla ERCP uygulamamız nedeniyle daha maliyetli, invaziv ișlem olan ERCP yapılmıștır. Özellikle akut fazda atlanan hastaların bilier obstrüksiyonla geldiği ve bu hastalar için invaziv bir ișlem olan ERCP yapılmak zorunda kalındığı olgular bildirilmiștir (Tablo 1).

Ülkemizde literatürde saptayabildiğimiz kadarıyla 2012 yılından bu yana 50'den fazla fascioliasis olgusu bildirilmiștir. Fakat bunların 13'üne ERCP yapılırken diğerlerine seroloji ve ERCP dıșı görüntüleme yöntemleri ile tanı konulmuștur. On üç olgunun ikisine safra yolları malignite șüphesiyle ERCP yapılırken 11 'ine bilier obstrüksiyon tanısıyla ERCP uygulanmıștır (Tablo 1) (1, 2, 7-13). Söz konusu olguların tanısında serolojik yöntemlerin (ayırıcı tanıda düşünülmemesi, serolojik yöntemlere ulașılamaması, uygulanmaması gibi nedenlerle) kullanılmadığı görülmektedir.

Fascioliasis tanısında fizik muayene, dıșkı mikroskobisi, serolojik yöntemler ve görüntüleme yöntemleri kullanılmaktadır (2, 6, 8). Kesin tanısı, dıșkıda ya da duodenal aspiratta parazit yumurtalarının saptanması ile konsa da parazitin az sayıda yumurta üretmesinden dolayı konvansiyonel laboratuvar yöntemleri ile tanı şansı düșüktür (6, 12). Fizik muayene ve klinik olarak șüphe edilen hastalardan ilk olarak dıșkı mikroskobisi, seroloji ve USG istenmelidir (2). Serolojik olarak IHA, IFA, ELISA, lateks aglütinasyon yöntemleri kullanılmaktadır (5). Kaya ve ark. (14), fascioliasis tanısında ELISA testinin tanısal değerini saptamak için yaptıkları bir çalıșmada testin duyarlılığını \% 100, özgüllüğünü ise \%95 olarak saptamışlardır. Fakat seroloji hakkında hekimlerin yeterli derecede bilgilendirilmemiș olmaları ve her merkezde bu imkanın olmaması nedeniyle seroloji ayağı

Tablo 1. Ülkemizde 2012 yılından bu yana ERCP ile tanı konarak literatüre geçmiş fasiyoliyazis vakaları

\begin{tabular}{lcclc}
\hline Yazar & Yılı & Kaynak & il & $\begin{array}{c}\text { Olgu } \\
\text { sayısı }\end{array}$ \\
\hline Ünal ve ark. & 2015 & 7 & Giresun & 1 \\
Șenateș ve ark. & 2014 & 8 & Diyarbakır & 1 \\
Bektaș ve ark. & 2014 & 1 & Diyarbakır & 1 \\
Ulger ve ark. & 2014 & 9 & Diyarbakır & 1 \\
Yılmaz ve ark. & 2014 & 10 & Afyon & 1 \\
Odabașı ve ark. & 2014 & 3 & İstanbul & 1 \\
Emir ve ark. & 2013 & 11 & Elazığ & 1 \\
Uyanıkoğlu ve ark. & 2013 & 2 & Şanlıurfa & 1 \\
Boğa ve ark. & 2012 & 12 & İstanbul & 1 \\
Sayılır ve ark. & 2012 & 13 & İstanbul & 4 \\
\hline Toplam & & & & 13 \\
\hline
\end{tabular}


genelde atlanmaktadır. Konu hakkında klinisyen ve parazitoloğun ișbirliği içinde olmaması, ilgili serolojik testi çalıșan laboratuvara ulașılamaması, fascioliasis ile ilgili tanı metodunun rehberlerde tam olarak yer almaması aksaklıkların diğer nedenleri arasındadır.

Serolojik yöntemlerin invaziv olmaması, risk içermemesi ve görüntüleme yöntemlerine göre ekonomik olması nedeniyle klinik olarak șüphe edilen hastalardan tanıda kullanılması hem hasta hem de hekim yararına olabilir. Özellikle ES-ELISA hızlı duyarlı ve özgül bir yöntem olarak bildirilmiștir (14). Bununla birlikte serolojik testlerinde bazı dezavantajları vardır. Akut ve kronik enfeksiyon ayrımı yapılamadığı gibi, diğer trematodlar yanında, $E$. granulosus ve
E. multilocularis gibi sestodlarla da çapraz reaksiyon verebilmektedir (14).

Fascioliasisli hastalarda eğer bilier obstrüksiyon varsa görüntüleme yöntemlerinden ERCP altın standarttır (11). ERCP, tanıdaki yararının yanında koledok içeriğini temizleyerek ve sfinkterotomi yaparak tedavi olanağı da sağlamaktadır (11). Fakat invaziv ișlem olması, deneyimli kiși ve ekipmana ihtiyaç duyması, safra yollarının perforasyonu gibi komplikasyonlarının olması dezavantajıdır.

Bu nedenle özellikle eozinofilisi olan hastalarda klasik triad sorgulanmalı ve bilier obstrüksiyon ve kolanjit yoksa günümüzde fascioliasis tanısının serolojik olarak konabildiği de akılda bulundurulmalıdır.

\section{ÇIKAR ÇATIȘMASI}

Yazarlar herhangi bir çıkar çatıșması bildirmemektedir.

\section{KAYNAKLAR}

1. Bektaș R, Yalçın K, Çiçek M.Cholestasis caused by Fasciola gigantica. Turkiye Parazitol Derg, 2014; 38: 201-4.

2. Uyanıkoğlu A, Demir K, Akyüz F, Ermiș F, Beșıșık F, Boztaș G. Hepatik kitle ile prezente olan ERCP ile ekstraksiyonu yapılan $F$. hepatica: olgu sunumu ve literatürün gözden geçirilmesi. Endoskopi, 2013; 21(2): 52-4.

3. Odabașı HM, Yildiz MK, Eriș C, Abuoğlu HH, Günay E, Özkan E, et al. Fasciola hepatica tanısında endosonografinin rolü. Endoskopi, 2014; 22(1): 21-4.

4. Kaplan M, Kuk S, Kalkan A, Demirdağ K, Özdarendeli A. Elazığ yöresinde $F$. hepatica seroprevalansının araștırılması. Mikrobiyol Bul, 2001; 36: 337-42.

5. Demirci M, Korkmaz M, Kaya S, Kuman A. Fascioliasis in eosinophilic patients in the Isparta Region of Turkey. Infection, 2003; 31(1): 15-8.

6. Miman Ö, Özkeçeci T, Okur N, Çiftçi ï, Polat C. Nadir bir tıkanma sarılığı sebebi: Fascioliasis. Turkiye Parazitol Derg, 2010; 34: 190-2.

7. Ünal N, Çaycı YT, Ecemiș Ö, Bektaș A, Hökelek M. Fasciola hepatica'nın endoskopik olarak çıkarılması: bir vaka. Turk Hij Den Biyol Derg, 2015; 72(2): 139-42.
8. Şenateș $E$, Doğan $A$, Şenateș $B E$, Bodakçi $E$, Bekçibașı M. An incidental case of biliary fascioliasis mimicking cholangiocellular carcinoma. Infez Med, 2014; 22(4): 313-6.

9. Ulger BV, Kapan M, Boyuk A, Uslukaya O, Oguz A, Bozdag Z, et al. Fasciola hepatica infection at a University Clinic in Turkey. J Infect Dev Ctries, 2014; 8(11): 1451-5.

10. Yılmaz B, Köklü S, Gedikoğlu G. Hepatic mass caused by Fasciola hepatica: a tricky differential diagnosis. Am J Trop Med Hyg, 2013; 89(6): 1212-3.

11. Emir S, Yazar MF, Sözen S, Altınsoy HB, Bulut HT, Özkan Z. Fasciola hepatica'ya bağlı olarak gelișen akut kolanjit ve pankreatit: olgu sunumu. Meandros Med Dent J, 2013; 14(3): 27-9.

12. Boğa $S$, Köksal AR, Altınkaya $E$, Özdoğan $O$, Ergün M, Alkım CA. Nöropati ile bașvuran Fasciola hepatica olgusu. Akad Gastroenterol Derg, 2012; 11 (2): 84-6.

13. Sayilir A, Ödemis B, Köksal AS, Beyazit Y, Kayacetin E. Image of the month: Fasciola hepatica as a cause of cholangitis. Am J Gastroenterol, 2012; 107(5): 655.

14. Kaya M, Beștaș R, Çiçek M, Önder A, Kaplan MA. The value of micro-ELISA test in the diagnosis of Fasciola hepatica infection. Turkiye Parazitol Derg, 2013; 37, 23-7. 


\section{Așı epidemiyolojisi: Așı etkililiği için epidemiyolojik çalışma tasanmlan}

\section{Vaccine epidemiology: Epidemiologic study designs for vaccine effectiveness}

\section{Can Hüseyin HEKIMOĞLU1}

\section{ÖZET}

Yeterli etkinliği gösterilmiș ve lisans almıș bir așının bir toplumda uygulanmasıyla ilgili hastalıktan korunma düzeyi ideal olmayan saha koșullarında, gözlemsel epidemiyolojik çalıșmalarla belirlenen 'aşı etkililiği' ile ölçülür. Toplumda ilgili hastalık insidandaki azalmanın uygulanan așılamadan mı, așılama dıșındaki nedenlerden mi kaynaklandığının belirlenmesi için, așı etkililiği sürveyansın bir parçası olarak rutin izlenmelidir. Bu nedenle așı etkililiği çalıșmaları halk sağlığı eylemleri için önemli bir role sahiptir. Kohort ve olgu kontrol çalıșmaları gibi klasik gözlemsel epidemiyolojik çalıșmalara alternatif olarak geliștirilen çeșitli çalıșma tasarımları da așı etkililiğini belirlemek için kullanılabilir. İlgili aşı ve hastalığa ve mevcut olanaklara göre kohort ve olgu kontrol çalıșmalarının yanı sıra indirekt kohort yöntemi, test negatif olgu kontrol tasarımı, olgu olgu çalıșması, tarama yöntemi, hane halkı temas çalıșması gibi alternatif tasarımlardan uygun olan kullanılarak aşı etkililiği belirlenebilir. Bu tasarımlardan bașka olgu kohort çalıșması, yuvalandırılmış olgu-kontrol çalıșması, insidans yoğunluğu olgu kontrol tasarımı gibi farklı alanlarda kullanılmakta olan tasarımlar da aşı etkililiğini belirlemek için seçilebilecek tasarımlar arasındadır. Ancak bu tasarımların hiç birinin mükemmel olmadığı ve çeșitli genel varsayımların yanı sıra tasarıma göre farklı varsayımlar altında yürütülmeleri gerektiği unutulmamalıdır. Gerekli varsayımların yerine getirilmediği ölçüde aşı etkililiği tahmini gerçek değerinden uzaklaşır. Așılı veya aşısız

\section{ABSTRACT}

Protection level against a disease of interest by application of a licenced vaccine whose effectiveness has been proved in a population is measured by "vaccine effectiveness" which is determined with observational epidemiological studies conducted under non-ideal field conditions. For determination of whether decrease in incidence of related disease in a population is due to vaccination or other reasons rather than vaccination, vaccine effectiveness should be monitored as a routine part of the surveillance. Therefore, vaccine effectiveness studies play an important role in public health actions. Various other study designs that are developed as an alternative to classical observational epidemiological studies such as cohort and case-control studies can also be used in determination of vaccine effectiveness. In accordance with related vaccine and disease and current facilities, vaccine effectiveness can be determined by using appropriate one of the alternative designs such as indirect cohort method, test-negative case-control design, case-case study, the screening method, household contact study, as well as cohort and case-control studies. Additionally, study designs which are used in other fields such as case-cohort study, nested case-control study, incidence density case-control design are among the designs that can be chosen for determination of vaccine effectiveness. However, it should be remembered that none of them is perfect and they should be performed under different assumptions related with each design, as well as various general assumptions. How necessary assumptions are not fulfilled, estimation of vaccine effectiveness will go far from its actual value. Any

I Dokuz Eylül Üniversitesi, Tıp Fakültesi, Halk Sağlı̆̆ı Ana Bilim Dalı, Epidemiyoloji Bilim Dalı, iZMiR

İletişim/Corresponding Author : Can Hüseyin HEKIMOĞLU

Dokuz Eylül Üniversitesi, Tıp Fakültesi, Halk Sağı̆̆ı Ana Bilim Dalı, Epidemiyoloji Bilim Dalı, IZMiR

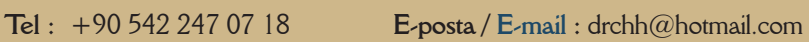

Geliş Tarihi / Received : 25.11 .2015

Kabul Tarihi/Accepted : 19.02 .2016

DOI ID : 10.5505/TurkHijyen.2016.28482

Hekimoğlu CH. Așı epidemiyolojisi: Așı etkililiği için epidemiyolojik çalıșma tasarımları. Turk Hij Den Biyol Derg, 2016; 73(2): $161-74$. 
gruptaki atak hızını olduğundan daha az veya daha fazla gösteren herhangi bir faktör așı etkililiği tahmininde taraf tutmaya yol açar. Bu faktörlerin tasarım așamasında veya analiz sırasında mümkün olduğunca kontrol edilmesi gerekir. Așı etkililiği tahminlerinin yanıltıcı olmaması için uygun tasarımın seçilmesi ve seçilen tasarıma göre gereken varsayımlar, olası taraf tutma kaynakları ve karıștırıcılar çalıșmanın planlama aşamasında ve çalıșma sonuçları yorumlanırken mutlaka göz önünde bulundurulmalıdır.

Anahtar Kelimeler: Așı etkililiği, așı epidemiyolojisi, çalıșma tasarımları factor that shows attack rate in vaccinated or unvaccinated groups less or more than its actual value leads to bias in estimating vaccine effectiveness. These factors should be controlled as much as possible in phase of design or during analysis. For vaccine effectiveness estimation not to be misleading; an appropriate study design should be selected and necessary assumptions in accordance with the selected design, potential bias sources and confounders should be taken into account in planning phase of the study and while study results are being interpreted.

Key Words: Vaccine effectiveness, vaccine epidemiology, study designs

\section{Gíriş}

Günümüzde hastalıkların önlenmesinde en bașarılı girișimlerden biri așılamadır. Așı ile hedeflenen hastalıktan korunma düzeyini ifade eden 'așı etkisi', girișimsel ve gözlemsel epidemiyolojik çalıșmalarla belirlenir (1-3). Așı etkisi așılananlarda așılanmayanlara göre ilgili hastalık insidansındaki azalma yüzdesi ile hesaplanır. Bu yüzde girișimsel bir çalıșmayla belirlendiyse 'așı etkinliği', gözlemsel bir çalıșmayla belirlendiyse 'așı etkililiği' elde edilir. Girișimsel çalıșmalar genellikle kısıtlı örnek büyüklüğü ile yürütülen faz 3 çalıșmaları oldukları için, aşı etkinliği ile yalnızca aşılı bireylerdeki 'direkt etki' gösterilebilmektedir. Eskiden 'saha etkinliği' olarak bilinen aşı etkililiği ise zaten yeterli etkinliği gösterilmiș olan așının, aslında kendisinin değil, bir toplumda uygulanmasının ilgili hastalıktan ne kadar koruduğunu göstermektedir. Așı etkililiği așının așılılardaki direkt etkisine ek olarak aşılamanın toplumda uygulandığında hastalık bulaşını azaltmasından kaynaklanan 'indirekt etki'yi de göstermektedir. Yüksek bir așı etkililiği, așı etkinliği ve așı kapsayıcılığının yüksek olmasının yanı sıra uygun koșullarda ve doğru bir așı uygulaması ile ilişkilidir (4-6).

Bir toplumda uygulamaya giren așının artan kapsayıcılığı ile birlikte hastalık insidansında gözlenen azalmanın așı uygulanmasından mı, așı dıșı nedenlerden mi kaynaklandığının ayırımının yapılabilmesi için, așı etkililiği hastalık sürveyansının bir parçası olarak izlenmelidir. Bu nedenle girișimsel çalıșmalara göre daha ucuz ve basit olan gözlemsel așı etkililiği çalıșmaları halk sağlığı eylemlerini planlamada çok önemli bir yer tutar $(2,5)$. Așı etkililiğinin belirlenmesi için klasik gözlemsel çalıșmalara alternatif olarak geliștirilen çeșitli epidemiyolojik çalıșma tasarımları da bulunmaktadır (7-14). Bu yazıda așı etkililiğinin belirlenmesinde kullanılan epidemiyolojik çalıșma tasarımlarına değinilmiștir.

\section{AŞI ETKILILILIĞi ÇALIŞMALARINDA VARSAYIMLAR}

Așı etkililiğini belirlemek amacıyla tasarlanan çalıșmalar çeșitli varsayımlar altında yürütülür. Bu varsayımların ihlali durumunda aşı etkililiği tahmini karıștırıcılık (confounding) ve taraf tutmadan (bias) etkilenir (4-6). Greenwood ve Yules așı çalıșmalarında yapılan çıkarımların geçerli olabilmesi için üç temel koșul belirlemișlerdir.

1) Ilk varsayım, çalıșmalardaki așılı ve așısız bireylerin așılanma durumu dıșında sonuca etkisi olan diğer tüm özelliklerinin benzer olduğu 
varsayımıdır (15). Karșılaștırılan gruplarda özellikle hastalığa duyarlılığın eșit olduğu varsayılır. Örneğin așılılar ve așısızlar arasında hastalığa karșı doğal bağıșıklık seviyeleri farklı olduğunda, bu varsayım yerine getirilmemiş olur. Böyle bir durum bir așı serolojik testlerle ilgili hastalığa duyarlı olduğu tespit edilen bireylere uygulanıyor, bağıșık olan bireyler aşılanmıyorsa görülebilir.

2) İkinci varsayım, așılı ve așısız gruplarda enfeksiyona maruziyet olasılıklarının aynı olduğudur. Örneğin așılanan grubun temas sıklığı așılanmayan gruba göre daha fazla olduğunda, bu varsayım yerine getirilemez ve așı etkililiği gerçek değerinden daha düșük tahmin edilir. Böyle bir durum bir așı yalnızca ilgili hastalık etkeniyle karșılașma açısından yüksek risk grubunda olanlara uygulanıyorsa görülebilir. Bu varsayım karșılanmadığında enfeksiyona maruziyet düzeyini de dikkate alan bulaș olasılığı ve sekonder atak hızı gibi koșullu ölçütlerle aşı etkililiği daha az taraf tutma ile tahmin edilebilir.

3) Son varsayım ise bireylerin aşılı olma olasılıklarının ilgili hastalığın gelișme riskinden bağımsız olduğudur. Așılama için hedef gruptaki bireyler hastalık gelișimi için daha yüksek olasılığa sahip olduklarında bu varsayım ihlal edilmiș olur. Örneğin influenza ve pnömokok aşıları için hedef grup altta yatan hastalığı olanlardır ve bu bireyler daha ciddi hastalık gelișimi için yüksek risk altındadırlar. $\mathrm{Bu}$ durumda ciddi hastalık gelişme riski yüksek olan bu grubun așılanma olasılıkları ciddi hastalık gelișme risklerinden bağımsız olmadığı için, aşının ciddi hastalık gelișimini önlemedeki etkililiğinin tahmininde 'endikasyona göre karıștırıcılık' (confounding by indication) söz konusudur $(6,15)$.

Așı etkileri hesaplanırken kullanılan formüller, bireylerin toplumda 'random' olarak karșılaștığı ve aşının toplumdaki bireylere 'random' olarak uygulandığı varsayımıyla uygulanır. Ancak gözlemsel çalıșmalarda așılananlar ve așılanmayanlar girișimsel çalıșmalarda olduğu gibi randomizasyonla araștırmacı tarafından değil, araștırmacıdan bağımsız olarak rutin uygulamayla belirlendikleri için; bu varsayımlar genellikle karșılanamaz. Gerçekte așılılar ve aşısızlar pek çok özellikleri açısından genellikle birbirlerinden farklıdırlar. Bu nedenle aşı etkililiği tahmini; yaș, krește olma, sağlık hizmeti arama davranıșı, fonksiyonel durum, ekonomik düzey, altta yatan hastalıklar gibi karıștırıcılardan etkilenebilir. Așılanma durumu, hastalık durumu ve muhtemel karıștırıcıların yakalanmasının așılı ve așısız grupta benzer olmaması halinde ortaya çıkacak taraf tutma așı etkililiği tahminlerinin geçerliliğini azaltacaktır. Bu nedenle bu çalıșmalarda yapılan tahminler aşılı ve aşısız grupta așılanma durumu, hastalık durumu ve ilgili karıștırıcıların yakalanmasının benzer olduğu varsayımı sağlandığında geçerli kabul edilmelidir. $\mathrm{Bu}$ formüller aşılıların toplumda homojen olarak dağıldığının yanı sıra așının așılılarda 'ya hep ya hiç' etkiye sahip olduğu varsayımına dayanmaktadır. Ya hep ya hiç varsayımına göre; bir aşı etkililiği \%95 ise aşılama ile tam aşılıların \%95'inde ilgili hastalık tamamen önlenebilir ve kalan \%5'inde herhangi bir koruma sağlanmaz. Aslında tam korunma olmayan așılılarda 'hiç korunma' değil, 'bir miktar' korunma olacaktır. Bu 'sızdıran așı etkisi' (leaky vaccine effect) gözlemsel çalıșmalarda göz ardı edilir. Așı etkililiği çalışmalarındaki bu genel varsayımların yanında çalıșma tasarımına göre farklı varsayımların da yerine getirilmesi gerekir. Așı etkililiği çalıșmalarının tasarlanmasında ve sonuçlarının yorumlanmasında bu varsayımlar mutlaka göz önünde bulundurulmalıdır. Aksi takdirde așı etkililiği tahminlerinin yanıltıcı olabileceği unutulmamalıdır $(4,16-18)$.

\section{OLASI TARAF TUTMA KAYNAKLARI}

Așı etkililiği çalıșmalarında yukarıda bahsedilen varsayımlar yerine getirilmediği ölçüde tahminler gerçek değerinden uzaklașır. Așılı veya așısız gruptaki atak hızını olduğundan daha az veya daha fazla gösteren herhangi bir etmen așı etkililiği tahmininde taraf tutmaya yol açar. Yani aşının etkililiği gerçekte olduğundan daha fazla veya daha azmış gibi bulunabileceği gibi, aslında koruyucu etkisi olan 
bir așı etkili değilmiș veya koruyucu etkisi olmayan bir așı etkisizmiș gibi de bulunabilir. Gözlemsel așı etkililiği çalışmalarının tasarım aşamasında veya analizi sırasında etkisi en aza indirilmesi gereken pek çok taraf tutma kaynağı ve karıștırıcı faktör vardır $(5,19)$.

\subsection{Olgu Tanımı}

Diğer epidemiyolojik çalıșmalarda olduğu gibi gözlemsel aşı etkililiği çalıșmalarında da olgu tanımının duyarlılığı ve özgüllüğünün \%100 olması istenir. Olgu tanımının duyarlılığı arttıkça așı etkililiği tahmininin de keskinliği artar. Ancak așı etkililiğinin nokta tahmini olgu tanımının duyarlılığının düșük olmasından, așılı ve așısız gruplarda duyarlılık eșit olduğu sürece, çok fazla etkilenmez. Örneğin boğmaca așısı olanlar, genellikle așısız olanlara göre daha hafif bir hastalık geçirecekleri için olgu tanımını karșılamayacaklardır. Bu durumda așılı grupta boğmaca olanlar gerçekte olduğundan daha az bulunur ve dolayısıyla așı etkililiği olduğundan fazla tahmin edilir. Bu tahmin aslında boğmacayı önlemede așı etkililiği değil, klinik olarak șiddetli boğmacayı önlemede aşı etkililiğidir (5).

Olgu tanımının özgüllüğü ise așı etkililiği tahmininde duyarlılığa göre daha önemlidir. Bașka hastalıkları olanların olgu olarak yanlıș sınıflandırılması, așılı grupta atak hızını așısız gruba göre daha fazla arttırır. Çünkü așılı grupta daha az gerçek olgu olması beklenir. Bu durum așı etkililiğinin gerçek değerinden daha düşük tahmin edilmesine neden olur. Hastalık ne kadar nadir görülüyorsa ve olgu olarak yanlıș sınıflandırılan hastalığın insidansı ne kadar yüksekse, așı etkililiği de o kadar düșük tahmin edilecektir. Böyle bir taraf tutma olgu tanımının duyarlıığı azaldıkça da artacaktır (5, 19-21).

Șekil 1'de așılı ve așısız 100'er kișilik iki gruptaki olgu sayıları görülmektedir. Așılı grupta 10 ve așısız grupta 40 olgu vardır. Bu örnekte olgu tanımının duyarlılığının ve özgüllüğünün \%100 olduğunu kabul edelim. Așılı gruptaki insidans 10 / $100=0,1$ ve așısız gruptaki insidans ise $40 / 100=0,4$ 'tür. Rölatif risk $0,1 / 0,4=0,25$ ve așı etkililiği ise $1-0,25=0,75$ (\%75) bulunur. Duyarlılık ve özgüllük \%100'den düșük olduğunda tespit edilecek olgu sayıları aşağıdaki formülle hesaplanabilir (22).

Tespit edilecek olgu sayısı $=$ (gerçek olgu sayısı $\mathrm{x}$ duyarlılık) + [(gerçek sağlam sayısı x (1 - özgüllük)]

Aynı örnekte, iki grupta da olgu tanımı için duyarlılı \%80 ve özgüllük \%90 olsaydı; o zaman aşılı grupta $(10 \times 0,8)+(90 \times 0,1)=8+9=17$ olgu ve așısız grupta $(40 \times 0,8)+(60 \times 0,1)=32+6=$ 38 olgu tespit edilecekti. Așılı grupta insidans 17 / $100=0,17$ ve așısız grupta insidans $38 / 100=0,38$ olacaktı. Bu durumda rölatif risk 0,17 / 0,38=0,44 ve aşı etkililiği $1-0,44=0,56$ (\%56) bulunurdu. Duyarlılığın \%80 ve özgüllüğün \%90’a gerilediği bu durumda, aşı etkililiği gerçek değerinden daha düșük bulunmuștur. Bir de özgüllüğün daha fazla azaldığı bașka bir durum düșünelim. Eğer olgu tanımı için duyarlılık \%90 ve özgüllük \%80 olsaydı; bu sefer așılı grupta $(10 \times 0,9)+(90 \times 0,2)=9+18=27$ ve aşısız grupta $(40 \times 0,9)+(60 \times 0,2)=36+12=48$ olgu saptanacaktı. Bu durumda așılı grupta insidans 27 / $100=0,27$ ve așisız grupta insidans $48 / 100=0,48$ bulunurdu. Rölatif risk $0,27 / 0,48=0,56$ ve aşı etkililiği $1-0,56=0,44(\% 44)$ olurdu. Örneklerde görüldüğü gibi duyarlılık ve özgüllük azaldığında așı etkililiği tahmini olduğundan daha düșük bulunmuș

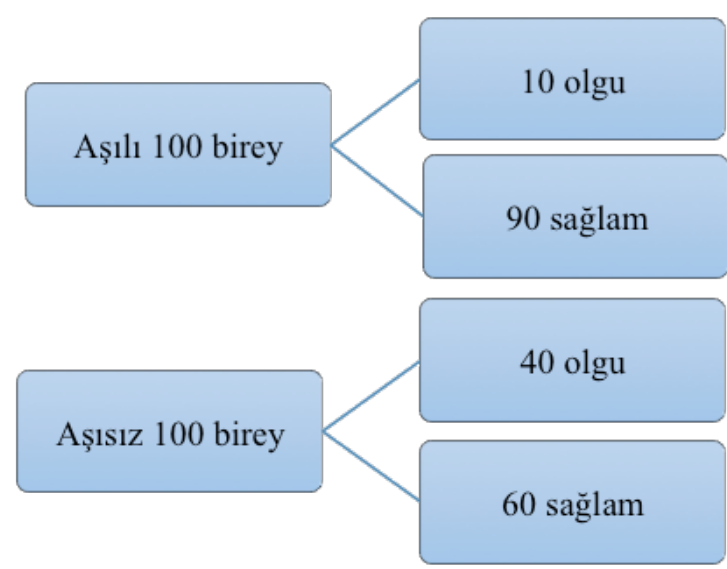

Şekil 1. Așılı ve așısız iki gruptaki olgu sayılar 
ve özgüllüğün duyarlılığa göre daha fazla azalması așı etkililiği tahmininde daha fazla taraf tutmaya neden olmuştur. Bu nedenle, çalıșmalarda bulunan farklı aşı etkililiği tahminlerini yorumlarken çalışmalardaki olgu tanımlarının duyarlılık ve özgüllüklerinin göz önünde bulundurulması önemlidir.

\subsection{Olgu Yakalama}

Randomize kontrollü çalıșmalarda özellikle hastalık durumunu belirleyen gözlemcinin bireylerin aşılanma durumu açısından kör tutulması ile olgular aşılanma durumundan bağımsız olarak değerlendirilir ve böylece olgu yakalamada taraf tutma azaltılabilir. Gözlemsel çalışmalarda ise așılı ve aşısız bireyler kendi kendilerine seçilmiş gruplardır ve bu grupların sağlık hizmetlerine erişiminin eșit olmaması halinde aşılı ve aşısız gruplarda olgu yakalama da farklı oranlarda olur. Örneğin așılılar sağlık hizmetlerine daha fazla erişebildikleri için așılanmış, așısızlar ise zaten sağlık hizmetlerine erișemedikleri için aşılanmamış olabilirler. Bu durumda aşılılar arasında daha fazla olgu yakalanmış olabilir ve aşı etkililiği ise gerçekte olduğundan daha az bulunabilir. Ayrıca daha ağır klinik belirtileri olan olgular daha fazla yakalanıyor ve daha hafif klinik belirtileri olanların tanısı atlanıyor olabilir. Bu durumda așıılıarda büyük olasılıkla daha hafif bir klinik gözleneceğinden, atak hızı olduğundan az ve așı etkililiği olduğundan fazla bulunur. Așılılar arasında olguların daha az yakalanması, örneğin hekimin aşılarının tam olduğunu bildiği çocuklarda boğmaca, kızamık gibi hastalıkları atlaması durumunda meydana gelir $(20,21,23)$.

Birleșik Krallık'taki bir boğmaca salgını incelemesinde olası olgu kriterlerini karșılayan 90 çocuğun yalnızca 31 'inin bildirildiği ve yalnızca bildirilen olgular çalıșmaya alındığında aşı etkililiğinin \%88 olduğu bulunmuștur. Olası olgular da çalıșmaya dahil edilğinde ise aşı etkililiği \%75 bulunmuștur. Olası olgu kriterlerini karșılamayan, en az iki hafta öksürük nöbetleri olan tüm çocuklar çalıșmaya dahil edildiğinde ise aşı etkililiği tahmininin \%68'e gerilediği görülmüștür. Yazar așılanmıș olduğu bilinen çocukların daha az tanı alıp daha az bildirildiğine dikkat çekmiștir (24). Bu nedenle aşı etkililiği çalıșmalarında en doğru aşı etkililiği tahminini yapabilmek için olgu yakalama hızı așılı ve așısız gruplarda eșit olmalıdır.

\subsection{Aşılanma Durumunun Tespiti}

Așılıolgularınaşısızolarakyanlıșsınıflandırılmasıyla aşısızlardaki atak hızı artarken, așılılardaki atak hızı azalacaktır. Bu durumda aşı etkililiği gerçekte olduğundan yüksek bulunur. Tersine aşısız olgular așılı olarak yanlıș sınıflandırıldığında, așılılarda atak hızı artarken, așısızlarda atak hızı azalacaktır. Bu durumda ise aşı etkililiği tahmini olduğundan düșük bulunur. Ailelerin çocuklarının aşılanma durumlarını hatırlamalarının așı kapsayıcılığının olduğundan fazla tahmin edilmesi yönünde olduğu görülmüștür. Yazılı kayıtlardan aşılanma durumu tespit edildiğinde ise aşı kapsayıcılığı olduğundan daha az tahmin edilebilir. Tam koruyuculuk için birden fazla doz aşılanma gereken durumlarda uygulanan aşı dozları da bilinmelidir. Tam doz așılanmayanlarda da bir miktar koruyuculuk olduğu ön görülüyorsa, bu durum analizde ayrıca ele alınmalı ve eksik aşılılardaki aşı etkililiği ayrıca belirlenmelidir. Eğer eksik aşılılar aşısız olarak değerlendirilirse, aşısızlardaki atak hızı düşer ve aşı etkililiği olduğundan daha az tahmin edilir. Eksik aşılılar tam așılı olarak değerlendirildiğinde ise așılılardaki atak hızı artar ve aşı etkililiği yine olduğundan daha az tahmin edilir. Bu nedenle tam aşılamanın etkililiği değerlendirilecekse eksik aşılılar dışlanmalı ve tam așılılar ile aşısızlar karșılaştırılmalıdır. Benzer șekilde aşılanma durumu bilinmeyenler, aşılı veya aşısız olarak kabul edilmemeli ve analizde yer almamalıdırlar (5, 19, 20, 25).

\subsection{Grupların Karşılaştırılabilirliği}

Gözlemsel çalıșma tasarımlarında genellikle aşılılar aşısızlardan așılanma ile ilișkili kişisel tercih, aşı kontrendikasyonuna sahip olma gibi özellikler açısından farklıdır. Eğer bu farklııklar hem aşılanma 
hem de ilgili hastalığın gelișimi ile ilișkili ise o zaman karıștırıcılık nedeniyle așı etkililiği tahmininde taraf tutulmuş olur. Örneğin aşısızlar daha düșük sosyo ekonomik düzeye sahip ve bu nedenle daha kötü beslenen ve hastalığa daha duyarlı bir göçmen grup olabilir. Gruplar arasındaki farklı özelliklerin bir kısmı araștırmacı tarafından fark edilebilir ve tasarım veya analiz aşamasında bu farklılıkların etkisi kontrol edilebilir. Ancak yine de fark edilmeyen veya ölçülmemiș farklılıkların sonuçların geçerliliğini azaltabileceği unutulmamalıdır.

Așı etkililiği çalıșmalarındaki en önemli karıștırıcı hastalığa maruziyettir. Hastalığa maruziyet düzeyi grupların, örneğin yaș ve yerleșim yeri dağılımları gibi, çeșitli özellikleri ilișkili olabilir. Așılamanın indirekt etkileri hem așılı hem de așısız gruplarda maruziyet olasılığını etkileyebilir ve bu etki gruplarda farklı büyüklükte olabilir. Bu nedenle așı etkililiğini toplum düzeyinde tahmin eden çalıșmalarda așının 'random' olarak uygulanıp uygulanmadığı önemlidir. Eğer yüksek așı kapsayıcılığına sahip grupların enfeksiyona maruziyet riski düșük ise, așı etkililiği ilgili hastalığa maruz kalan bireylerdeki koruyuculuk düzeyini gösterir. Bu durumda toplumda așilanma durumunun kümelenmesi yanlış olarak yüksek aşı etkililiği tahminiyle sonuçlanır. Benzer șekilde düșük așı kapsayıcılığı olan gruplar hastalığa daha fazla maruz kalabilirler ve bu durumda așı etkililiği yanlıș olarak düșük bulunabilir. Yaș ise hem önceden ilgili hastalığa maruz olma olasılığı hem de aşılanma olasılığı ile ilișkili olabilir. Hastalığı geçirmekle veya așılama ile erken yașta gelișen bağıșıklık zamanla azaldığında, yaș așılamadan sonra geçen zaman için bir gösterge olabilir. Bu nedenle veriler dar yaş gruplarında ayrı ayrı analiz edilmeli veya yașa göre standardize edilmelidir (5, 19, 20, 26).

Bir bireyin așılanma için bir sağlık kurumuna bașvuruda bulunması genel olarak o kișinin kendi sağlığı açısından daha olumlu davranıșlarda bulunduğunun bir göstergesi olabilir. Bu bireyler kendi sağlıkları için yapılan öneriler doğrultusunda hareket eden, daha yüksek öğrenim düzeyindeki bireyler olabilirler ve aynı zamanda herhangi bir nedenle hastaneye yatma ve ölme olasılıkları da daha düșük olabilir. Benzer șekilde, genel olarak sağlıkları açısından olumlu davranıșlarda bulunmayan bireylerin așılanma için bașvuruda bulunma olasılıkları daha düșük ancak hastaneye yatıș veya ölme olasılıkları daha yüksek olabilir. Bu durum 'sağlıklı aşılı etkisi' (healthy vaccine effect) olarak bilinir. Sağlıklı așılı etkisi nedeniyle așılananlarda daha az hastalık gelișimi gözlenirken, așısızlarda daha fazla hastalık gelișir ve așının etkililiği bu durumda olduğundan daha fazla bulunur $(6,27)$. Bu nedenle gözlemsel aşı etkililiği çalıșmalarında așılı ve așısız grupların mümkün olduğunca karșılaștırılabilirliğinin sağlanması ve karıștırıcı faktörlerin göz önünde bulundurulması önemlidir.

\section{AŞI ETKILILIĞi IÇiN EPIDEMIOYOLOJiK ÇALIŞMA TASARIMLARI}

Așı etkililiği kohort ve olgu kontrol çalıșmaları gibi klasik gözlemsel epidemiyolojik çalıșma tasarımlarının yanı sıra, bu klasik tasarımlardan türetilmiș alternatif aşı etkililiği çalıșma tasarımlarıyla da belirlenebilir. Ayrıca olgu kohort çalıșması (case-cohort study), yuvalandırılmıș olgu kontrol çalıșması (nested casecontrol study), insidans yoğunluğu olgu kontrol tasarımı (incidence density case-control design) gibi farklı alanlarda kullanılmakta olan tasarımlar da aşı etkililiğini belirlemek için kullanılabilir (7-14, 28-32).

\subsection{Kohort Çalıșması}

Kohort çalıșmaları, ilgili hastalık için risk altındaki toplum ayrı olarak tanımlanabildiğinde așı etkililiğini belirlemek için en uygun çalıșma tasarımıdır. Kohort çalıșmalarında aynı toplumdaki (kohort) așılı ve așısız grupların hastalık gelișme riskleri (insidans) karșılaștırılır. Kohort genellikle bir okul, kreș, kurum vb. tabanlı olarak veya coğrafi olarak belirlenmiș bir alanda tanımlanır. Kohorttaki tüm bireylerin așılanma durumları ve sonra așılı ve așısız gruplardaki 
atak hızları belirlenerek rölatif risk hesaplanır. Așı etkililiğini hesaplamada bu rölatif risk kullanılır. Aşı etkililiğini belirlemek için tasarlanan kohort çalışmaları genellikle retrospektif olarak yürütülür. Örneğin kurum, okul salgınlarında retrospektif kohort tasarımı sık kullanılır (4-6). Salgın incelemelerinin bir parçası olarak yürütülen kohort çalıșmalarında taraf tutmayı azaltmak için 5 kriter tanımlanmıștır:

1) Çalıșılan yaş gruplarında önemli ölçüde önceden hastalık aktivitesinin olmaması,

2) Hem așılı hem de aşısız bireylerin çalıșma grubuna dahil edilmesi,

3) Toplumda çalıșılacak yaș grubunda yeterli sayıda kiși olması,

4) Yüksek atak hızı olması,

5) Mevcut aşı kayıtlarının iyi olması (33).

Salgın uzun süreli ise veya așılanma durumu salgın kontrol önlemlerine bağlı olarak salgın sırasında önemli ölçüde değișiyorsa o zaman kiși-zaman analizi gerekir (4).

Şekil 2'de rekombinan hepatit B așısının etkililiğinin belirlenmesi için Brezilya'da yürütülen bir retrospektif kohort çalıșma tasarımı görülmektedir. Çalıșmada 1998-2002 döneminde düzenli kan donörü olan 15-65 yaș arası bireyler kohortu olușturmaktadır. Birinci kohortta 698 aşılı ve ikinci kohortta 713 aşısız birey bulunmaktadır. Așılı kohort toplam 2.715 kiși-yıl, așısız kohort ise 1.717 kiși-yıl izlenmiștir. İzlem süresince așılı kohortta hiç hepatit B gelișimi gözlemlenmezken, așısız kohortta 4 hepatit B olgusu gelișmiștir. Așılı kohorttaki insidans hızı 0,00 / 1.000 kiși-yıl, așısız kohortta ise 2,33 / 1.000 kiși-yıl olarak bulunmuştur. Rölatif risk $0,00 / 2,33=0,00$ ve așı etkililiği 1 - 0,00 = 1,00 (\%100,0 \%95GA: \%30,0$\% 100,0)$ olarak hesaplanmıștır. Bu çalıșmaya göre, rekombinant hepatit $B$ așısının hepatit B gelișimini önlemede etkililiği \%100'dür (13).

\subsection{Olgu Kontrol Çalıșması}

Așı etkililiğini belirlemek için yürütülen olgu kontrol çalıșmalarında, hastalananlar veya enfekte olanlar (olgular) arasındaki așılanma odds'u (așılı / aşısız oranı) uygun kontrollerin așılanma odds'u ile karșılaștırılarak, așılanmanın odds ratio (OR)'su belirlenir ve bu OR kullanılarak aşı etkililiği hesaplanır. Çalıșmaya alınan kontrollerin olguların içinden geldiği toplumun aşı kapsayıcılığını temsil ettiği varsayılır (4-6). Difteri, polio, tüberküloz gibi 'olgu/enfeksiyon oranı' düşükk hastalıklar için așı etkililiğini belirlemede olgu kontrol çalıșmaları daha verimli ve pratik tasarımlar olabilirler. Atak hızı yüksek olduğunda, kümülatif insidans olgu kontrol çalışması için nadir hastalık varsayımı geçerli olmaz. Bu durumda olgu kohort veya insidans yoğunluğu olgu kontrol çalıșması, nadir hastalık varsayımı gerektirmediği için, iyi bir alternatif olabilir (4).

Olgu kontrol çalıșmalarındaki olgular toplumdaki olguların bir kısmıdır ve kontroller hasta olmayan

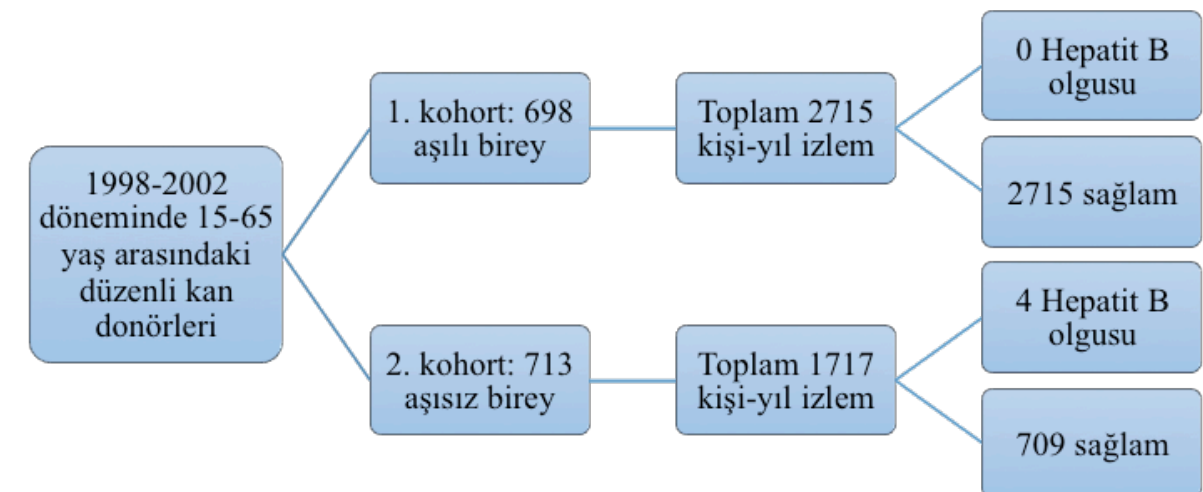

Şekil 2. Rekombinan hepatit B aşısının etkililiğinin belirlenmesi için yürütülen bir retrospektif kohort çalıșma tasarımı (23) 
toplumun tümünü değil bir örneğini yansıtır. Olgu kontrol çalıșmalarında örnekleme kesri (sampling fraction) bilinmediğinden, așılı ve așısız toplam nüfus hesaplanamaz ve bu nedenle atak hızlarına ulașılamaz. Ancak nadir hastalıklar için OR yaklaşık olarak rölatif riske eșit olduğu için așı etkililiği tahmini için kullanılabilir. Atak hızı > \%10 olduğu durumlarda ise OR kullanılarak hesaplanan așı etkililiği tahmini yanlıș olarak daha yüksek bulunur $(4-6,33)$.

Şekil 3'te maternal boğmaca aşılamasının yenidoğanlardaki etkililiğinin tahmin edildiği İngiltere ve Galler'de yürütülmüș bir olgu kontrol çalıșma tasarımı görülmektedir. Polimeraz zincir reaksiyonu (PCR) ile doğrulanmış boğmaca tanısı olan < 8 haftalık bebekler olgu grubu, olguların aile hekimlerine kayıtlı olup olgudan sonra doğan ilk bebek ise kontrol grubu olarak alınmıș ve gruplarda annenin gebelikte boğmaca aşısı olma odds'ları karșılaștırılmıștır. Çalıșmadaki toplam 58 olgunun 10 'unun ve 55 kontrolün 39'unun annesi gebeliğinde boğmaca așısı olmuștur. Odds ratio $(10 \times 16) /(48 \times$ 39) $=0,085$ ve așı etkililiği $1-0,085=0,915(\% 91,5)$ bulunmuștur. Bu çalıșmaya göre, maternal boğmaca așısının < 8 haftalık bebeklerde PCR ile doğrulanmıș boğmacayı önlemede etkililiği \%91,5'tir (14).

Așı etkililiğinin belirlenmesi için olgu kontrol çalıșmalarından köken alan ve birbirlerinden özellikle kontrollerin seçimi ile ayrılan çeșitli alternatif

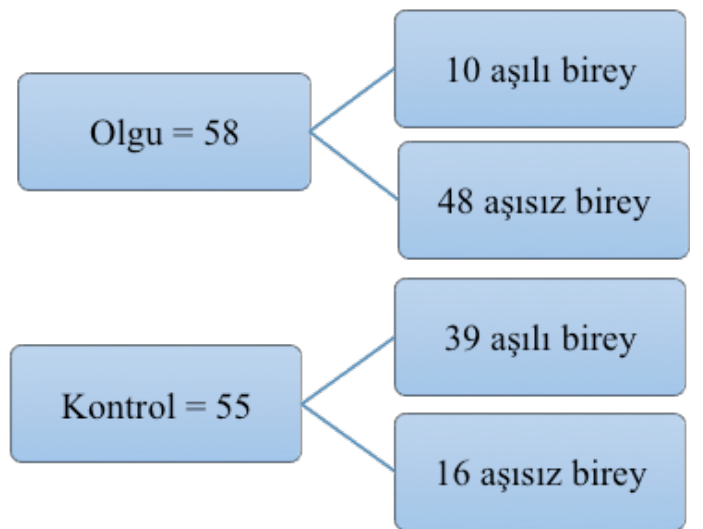

Şekil 3. Maternal boğmaca aşılamasının yenidoğanlardaki etkililiğinin tahmini için yürütülen bir olgu kontrol çalıșma tasarnmı (14) tasarımlar geliștirilmiștir: indirekt kohort tasarımı, test negatif olgu kontrol tasarımı, olgu olgu çalıșması ve tarama yöntemi. Bu tasarımlar așı etkililiği çalıșmalarının genel varsayımlarına ek olarak tasarıma özel varsayımların da yerine getirildiği durumlarda uygulanmalıdır (4-14).

\subsection{Indirekt Kohort Tasarımı (Broome}

\section{Yöntemi)}

İndirekt kohort tasarımı yalnızca serotip veya serogrupları olan etkenlerin așılarının etkililiğinin belirlenmesi için geliștirilmiștir. Etkenin așı içeriğinde yer alan bir serotipiyle hastalık gelișenler olgu olarak çalıșmaya alınırken, kontroller etkenin așı içeriğinde yer almayan serotipleriyle hastalık gelișenlerdir. Böylece olgu ve kontroller arasındaki yakalamaya bağlı taraf tutma kontrol edilmiş olur. Yöntem așılı kișilerin etkenin aşı içeriğinde yer alan tipleri dıșındaki enfeksiyonlar için așısızlarla aynı riske sahip olduğunu varsayar. Bu nedenle yöntemin uygulanabilmesi için etkenin așı içeriği dıșında kalan tiplerine karșı așının çapraz koruyuculuğunun olmaması gerekir. Ayrıca așılama ile etkenin așı içeriği dıșında kalan tipleri ile hastalık gelișme riski de artmamıș olmalıdır (4, 6, 34). Örneğin influenza așılarının değerlendirilmesinde bu yöntem uygun değildir. Çünkü influenza așısı içeriğinde yer almayan influenza tiplerine karșı da așının bir miktar koruyuculuğu olabilir (35). Bu yöntemde örneğin tüm invaziv pnömokokal hastalık (IPH) olguları bir kohort gibi düșünülerek, așılı ve așısızlar olarak iki kola ayrılmazlar. Klasik olgu kontrol tasarımında olduğu gibi etkenin așı içeriğinde yer alan ve așı içeriği dıșında kalan serotipleri ile hastalık gelișenler arasındaki aşılanma durumları (odds'ları) karșılaștırılarak elde edilen OR kullanılarak așı etkililiği hesaplanır $(4,6,34)$.

Amerika Birleșik Devletleri'nde 7 valanlı konjuge pnömokok așısının (KPA-7) 2-59 aylık çocuklarda etkililiğinin değerlendirildiği bir çalıșmada yaklaşık 3,5 yıllık IPH sürveyansı verileri kullanılmıștır. Çalıșmada KPA-7'nin içeriğinde yer alan serotipler (4, 6B, 9V, 14, 18C, 19F, 23F) ile IPH gelișen çocuklar 
olgu grubunu oluștururken, bu serotipler dișındaki serotiplerle IPH gelișen çocuklar ise kontrol grubunu olușturmuştur. En az bir doz KPA-7 ile aşılanmıș olan çocuklar aşılı kabul edilerek, toplam 153 olgunun 74'ünün ve 919 kontrolün 825'inin aşılı olduğu tespit edilmiștir. Odds ratio $(74 \times 94) /(79 \times 825)=0,106$ ve așı etkililiği $1-0,106=0,894(\% 89,4)$ bulunmuștur. $\mathrm{Bu}$ çalıșmaya göre, KPA-7'nin 2-59 aylık çocuklarda KPA7'nin içeriğinde yer alan serotiplerle IPH gelişimini önlemede etkililiği \%89,4'tür (8).

\subsection{Test Negatif Olgu Kontrol Tasarımı}

Test negatif olgu kontrol tasarımında ilgili hastalığın tanısı için laboratuvar test sonucu negatif olan klinik olgular kontrol, pozitif olanlar ise olgu olarak alınır. Böylece sağlık hizmetlerine erișim farklılı̆ından kaynaklanan olgu yakalamadaki taraf tutma engellenmiş olur. Yöntem kontrollerdeki hastalıkların ilgili aşıdan etkilenmediğini varsayar. Ayrıca bu yöntem söz konusu laboratuvar testinin duyarlılığının yüksek olduğunu kabul eder ve yalancı negatiflikleri de yok sayar (misclassification bias) (6, 36). Son yillarda özellikle sentinel sürveyans verileri kullanılarak influenza aşı etkililiği izleminde test negatif olgu kontrol tasarımı sık kullanılmaktadır. Sentinel influenza sürveyansı kapsamında influenza benzeri semptomu olanlardan influenza için test edilmek üzere alınan örneklerinde influenza testi pozitif saptananlar olgu iken, negatif saptananlar kontrol olarak alınır (37-40).

İspanya'da rotavirus aşısının 3-59 aylık çocuklarda etkililiğini belirlemek için yapılan bir çalıșmada akut gastroenterit tablosu olan ve dıșkıda rotavirus antijeni bakılan çocuklar test sonucuna göre olgu ve kontrol gruplarına ayrılmıștır. Dıșkıda rotavirus antijeni pozitif tespit edilen (olgu) 756 bireyin 45'inin așıl1, 711'inin aşısız; negatif tespit edilen (kontrol) 6.036 bireyin 1.094'ünün așil, 4.942'sinin aşısız olduğu saptanmıştır. Odds ratio $(45 \times 4.942) /$ $(711 \times 1.094)=0,285$ ve așı etkililiği $1-0,285=0,715$ $(\% 71,5)$ bulunmuştur. Bu çalıșmaya göre, rotavirus aşısının 3-59 aylık çocuklarda rotavirusa bağlı akut gastroenterit gelișimini önlemede etkililiği \%71,5’tir (10).

\subsection{Olgu Olgu Çalıșması}

Test negatif olgu kontrol tasarımında olduğu gibi seçime dayalı taraf tutmayı önlemek için olgu olgu çalıșmalarında kontrol olarak bașka bir etiyolojiye sahip olanlar alınır. Asında kontrol grubundaki bireyler de bașka bir hastalığa sahip olgulardır. Ancak etkililiği değerlendirilen aşının kontrol olarak seçilenlerdeki hastalıklara etkisinin olmaması gerekir $(6,9,41$, 42). Örneğin pnömokok așısının etkililiğini Broome yöntemiyle belirlemek istediğimizde; pnömokok için test edilen bireyler çalıșmaya alınır ve aşı içeriğindeki serotiplerle hastalık gelișenler ile așı içeriğinde olmayan serotiplerle hastalık gelișenler așılanma durumları açısından karşılaştırıır. Test negatif olgu kontrol tasarımında ise örneğin pnömokok kültürü yapılanlar çalıșmaya alınarak, pnömokok üreyenler ve üremeyenler karșılaștırılır. Klasik bir olgu kontrol çalıșmasında örneğin pnömoni olanlar ve olmayanlar karşılaştırılabilir. Bir olgu olgu çalıșmasında ise pnömokok üreyenler ile pnömokok dışında bir etken üremesi olanlar karșılaștırılmaktadır.

İspanya'da 2010-2011 sezonunda erișkinlerde laboratuvar konfirme influenza nedeniyle hastaneye yatıșları önlemede așı etkililiği bir olgu olgu tasarımı ile belirlenmiștir. Çalıșmaya influenza benzeri hastalık nedeniyle hastaneye yatırılan ve influenza ve diğer solunum yolu virusları için test edilen 826 birey alınmıştır. Test sonuçlarına göre 606 kișide testler negatif saptanırken, influenza konfirme edilen 102 kiși ile diğer solunum yolu virusları açısından pozitif saptanan 116 kiși aşılanma durumu açısından karșılaștırılmıştır. İnfluenza olguları arasında 37 așılı ve 65 aşısız ve diğer solunum yolu virusu olguları arasında 77 așılı ve 39 așısız vardır. Odds ratio (37 x 39) / $(77 \times 65)=0,288$ ve așı etkililiği $1-0,288=0,712$ $(\% 71,2)$ bulunmuștur. Bu çalıșmaya göre, 2010-2011 sezonunda erișkinlerde laboratuvar konfirme influenza nedeniyle hastaneye yatışları önlemede așı etkililiği $\% 71,2$ 'dir (9). 


\subsection{Tarama Yöntemi}

Olgu kapsayıcılık tasarımı (case-coverage design) olarak da bilinen tarama yönteminde (the screening method) olguların içinde așılıların oranı ile toplumdaki așılıların oranı karșılaștırılarak așı etkililiği belirlenir. Diğer bir ifade ile kontrol olarak toplumdaki aşı kapsayıcılığı alınmaktadır. Toplumdaki aşı kapsayıcılığı bilindiğinde veya tahmin edilebildiğinde bu yöntem hızı bir așı etkililiği taraması için uygun bir araçtır, ancak bu yöntemin kesin bir așı etkililiği tahmini sağlamadığı unutulmamalıdır. Beklenenden düşük bir așı etkililiği tahmini elde edilirse diğer tasarımlar ile bunun doğrulanması gerekir. Diğer tasarımlardan farklı olarak tarama yönteminde așı etkililiği așağıdaki formülle hesaplanır (4-6, 43).

Așı etkililiği = 1 - (așılı olguların oranı / așısız olguların oranı) x (așısız toplum oranı / așılı toplum oranı)

$\mathrm{Bu}$ yaklașım aslında tüm toplumun kontrol olarak alındığı bir olgu kontrol çalıșmasındaki odds ratio hesabıyla elde edilen așı etkililiği tahminiyle aynı sonucu verir. Așılı toplumun veya așılı olguların oranı çok düşük veya çok yüksek olduğu durumlarda yöntem hatalara karșı daha duyarlıdır ve așılı olgu / așılı toplum oranındaki küçük değișikliklerle aşı etkililiği tahmininde büyük farklılıklar görülür $(4-6,43)$.

Şekil 4'te tarama yöntemi kullanılarak ABD'de 19-35 aylık çocuklarda KPA-7'nin IPH'yi önlemede etkililiğinin izlendiği bir çalıșma tasarımı görülmektedir. Çalıșmada 2002 ve 2007 yılları için IPH sürveyans siteminden olgular elde edilmiș ve ulusal bağıșıklama araștırmasından așı kapsayıcılığı (VC) tahmin edilmiștir. İkibin iki yılında 10'u aşılı 27 olgu varken, 2007 yılında ise saptanan iki olgunun biri aşılıdır. Așı kapsayıcılığı ise 2002 yılında \%74 iken, 2007 yılında \%98'dir. Așı etkililiği 2002 yılı için 1 - $(10 / 17 \times 26 / 74)=0,794(\% 79,4)$ bulunurken, 2007 yılı için 1 - (1/1 x 2 / 98) = 0,979 (\%97,9) bulunmuștur. Bu çalıșmaya göre, KPA-7'nin 19-35 aylık çocuklarda IPH'yi önlemede etkililiği 2002 yılında \%79,4 ve 2007 yılında \%97,9'dur. Bu çalıșmada da görüldüğü gibi aşı kapsayıcılığı arttıkça aşı etkililiği de artmaktadır. Artan așı kapsayıcılığı ile olguların sayısı azalmıș, ancak olguların içindeki așılıların oranı artmıștır (11). Toplam olgu sayısı ve așı kapsayıcılığını dikkate almadan yalnızca așılı olguların oranına bakılarak aşının etkililiğini değerlendirmenin yanıltıcı olabileceği unutulmamalıdır (4).

\subsection{Hanehalkı Temas Çalışması}

'Hanehalkı temas çalıșması' (household contact study) așılı ve așısız gruplar arasındaki enfeksiyona maruziyet düzeyindeki farklılıkları ve dolayısıyla bu farklılıklardan kaynaklanan taraf tutmayı azaltmak için tercih edilir. Çalıșmada primer olguların bulunduğu hanelerdeki primer olgu hariç toplam nüfus bir araya getirilerek olușturulan kohortta așılı ve așısız gruplar belirlenir. Așılı ve așısız gruplardaki sekonder atak hızları hesaplanır ve bu hızların oranı kullanılarak aşı etkililiği hesaplanır. Bu yöntem kızamık için randomize kontrollü çalıșmalarla aynı sonucu vermiștir. Diğer taraftan boğmaca için bu yöntem tanı kriterlerinden bağımsız olarak maruziyetin hanehalkı arasında daha yoğun olmasına, așı bașarısızlığı olasılığı yüksek olan hanelerin çalıșmaya dahil edilmiș olmasına bağlı olarak așı etkililiğini daha az tahmin edebilir (4-6, 19, 33).

Bu tasarımda primer olgu așılı olduğunda, așılılarda hastalığın șiddeti ve bulaștırıcılığı daha az olacağı için, temaslılarına bulaș olasılığı așısız primer bir olguya göre daha düșük olur ve aşılı primer olguların oranı

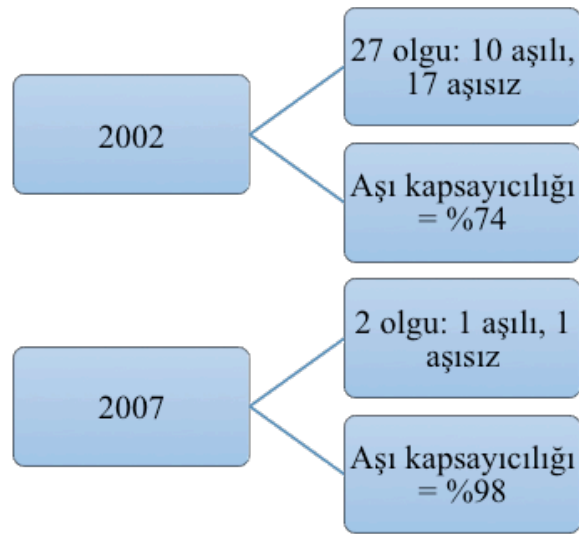

Şekil 4. Tarama yöntemi kullanılarak 19-35 aylık çocuklarda 7 valanlı konjuge pnömokok aşısının invaziv pnömokokal hastalığı önlemede etkililiğinin izlendiği bir olgu kapsayıcılık çalıșma tasarımı (11) 
arttıkça aşı etkililiği tahmini de olduğundan yüksek bulunur. Ayrıca așı bașarısızlığı için risk faktörleri hanehalkı üyeleri arasında ortak olabilir, bu nedenle aşının aleyhine bir taraf tutma söz konusu olabilir. Olgu saptanmayan hanelerin çalıșmaya alınmaması nedeniyle de așının daha iyi çalıștığı haneler dıșlanmıș olur. Bu durumda așı etkililiği daha düșük tahmin edilebilir (4-6).

Kalifornia'da 1997-2001 yılları arasında bildirilen suçiçeği olgularının 1-14 yaș arası hanehalkı temasılırı ile yürütülen çalıșmanın tasarımı Şekil 5'te görülmektedir. Çalıșmada döküntü bașlangıç tarihine göre hanedeki ilk olgu primer olgu ve primer olgunun 10-21. günleri içinde döküntü görülen olgular ise sekonder olgu olarak tanımlanmıștır. Hanedeki primer olgunun 0-9. günü içinde döküntü görülen olgular da primer olgu kabul edilerek analizden dișlanmıștır. Toplam 6.316 olgu saptanan çalıșmada, 1-14 yaș grubundaki așısız primer bir olguyla temaslı 1.665 bireyden 166'sı așılı, 1.499'u așısızdır. Așılı primer olgular ve temaslıları taraf tutmaya neden olmaması için çalıșmaya dahil edilmemișlerdir. Așılı 166 temaslı arasında 25 olgu ve așısız 1.499 temaslı arasında 1.071 olgu saptanmıștır. Sekonder atak hızı așılılarda 25 / $166=0,15$ ve așısızlarda $1.071 / 1.499=0,714$ 'tür. Sekonder atak hızları oranı 0,15 / 0,714=0,21 ve așı etkililiği 1 - 0,21 = 0,79 (\%79) bulunmuștur. Bu çalıșmaya göre, suçiçeği așısının 1-14 yaș grubunda suçiçeği gelișimini önlemede etkililiği \%79'dur (12).

Yukarıda bahsedilen gözlemsel çalıșma tasarımlarının yanı sıra lisans sonrası dönemde așı etkililiğini belirlemek için matematiksel modellemelerden de yararlanılabilir. Özellikle son yıllarda kullanımları artan bu modellemeler așı programlarının etkilerinin değerlendirilmesinde ve maliyet etkililik analizlerinde öne çıkmaktadır. $\mathrm{Bu}$ modellemeler ayrıca lisans öncesi dönemde aşı etkinliği belirlemek için de kullanılmaktadır (44-52).

\section{SONUÇ}

Așı etkililiğini belirlemek için yaygın olarak kullanılan klasik gözlemsel çalıșma tasarımlarının yanı sıra alternatif tasarımlar da mevcuttur. Ancak bu tasarımların hiçbiri mükemmel değildir. İlgili așı ve hastalığa, mevcut olanaklara göre uygun olan çalıșma tasarımının seçilmesiyle daha doğru, verimli bir șekilde așı etkililiği tahminleri yapılabilir. Așı etkililiği çalıșmalarında, yanıltıcı așı etkililiği tahminlerinden kaçınmak için; gerekli varsayımlar, karıștırıcılık, olası taraf tutma kaynakları, tasarım așamasında ve sonuçların yorumlanmasında mutlaka göz önünde bulundurulmalıdır.

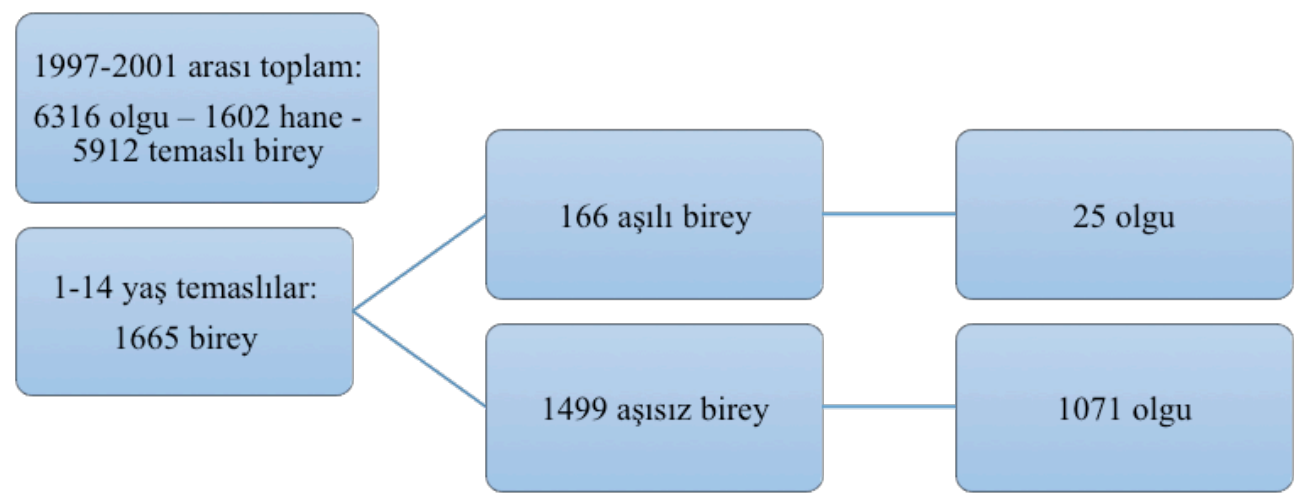

Şekil 5. California'da 1997-2001 yıllan arasında bildirilen suçiçeği olgularının 0-14 yaș arası hanehalkı temasılan ile yürütülen bir hanehalkı temas çalıșması tasarımı (12)

ÇIKAR ÇATIŞMASI

Yazarlar herhangi bir çıkar çatıșması bildirmemektedir. 


\section{KAYNAKLAR}

1. World Bank. World development report 1993: investing in health. New York, NY: Oxford University Press, 1993: 72-107.

2. Weinberg GA, Szilagyi PG. Vaccine epidemiology: efficacy, effectiveness, and the translational research roadmap. J Infect Dis, 2010; 201(11): 1607-10.

3. Begg N, Miller E. Role of epidemiology in vaccine policy. Vaccine, 1990; 8(3): 180-9.

4. Chen RT, Orenstein WA. Epidemiological methods in immünization programs. Epidemiol Rev, 1996; 18(2): 99-117.

5. Torvaldsen S, Mclntyre PB. Observational methods in epidemiologic assessment of vaccine effectiveness. Commun Dis Intell Q Rep, 2002; 26(3): $451-7$.

6. Hanquet G, Valenciano M, Simondon F, Moren A. Vaccine effects and impact of vaccination programmes in post-licensure studies. Vaccine, 2013; 31(48): 5634-42.

7. Simpson CR, Lone NI, Kavanagh K, Ritchie LD, Robertson C, Sheikh A, et al. Trivalent inactivated seasonal influenza vaccine effectiveness for the prevention of laboratory-confirmed influenza in a Scottish population 2000 to 2009. Euro Surveill, 2015; 20 (8).

8. De Serres G, Pilishvili T, Link-Gelles R, Reingold A, Gershman K, Petit S, et al. Use of surveillance data to estimate the effectiveness of the 7-valent conjugate pneumococcal vaccine in children less than 5 years of age over a 9 year period. Vaccine, 2012; 30 (27): 4067-72.

9. Puig-Barberà J, Díez-Domingo J, Arnedo-Pena A, Ruiz-García M, Pérez-Vilar S, Micó-Esparza $\mathrm{JL}$,et al. Effectiveness of the 2010-2011 seasonal influenza vaccine in preventing confirmed influenza hospitalizations in adults: a case-case comparison, case-control study. Vaccine, 2012; 30(39): 5714-20.

10. Castilla J, Beristain X, Martínez-Artola V, Navascués A, García Cenoz M, Alvarez N, et al. Effectiveness of rotavirus vaccines in preventing cases and hospitalizations due to rotavirus gastroenteritis in Navarre, Spain. Vaccine, 2012; 30(3): 539-43.
11. Cohen AL, Taylor T Jr, Farley MM, Schaffner W, Lesher LJ, Gershman KA, et al. An assessment of the screening method to evaluate vaccine effectiveness: the case of 7-valent pneumococcal conjugate vaccine in the United States. PLoS One, 2012; 7(8) :e41785.

12. Seward JF, Zhang JX, Maupin TJ, Mascola L, Jumaan AO. Contagiousness of varicella in vaccinated cases: a household contact study. JAMA, 2004; 292(6): 704-8.

13. Kupek E, de Souza DE, Petry A. Effectiveness of DNA-recombinant anti-hepatitis $B$ vaccines in blood donors: a cohort study. BMC Infect Dis, 2007; 7: 124.

14. Dabrera G, Amirthalingam $G$, Andrews N, Campbell $\mathrm{H}$, Ribeiro S, Kara E, et al. A case-control study to estimate the effectiveness of maternal pertussis vaccination in protecting newborn infants in England and Wales, 2012-2013. Clin Infect Dis, 2015; 60(3): 333-7.

15. Greenwood M, Yule GU. The Statistics of Antityphoid and Anti-cholera Inoculations, and the Interpretation of such Statistics in general. Proc R Soc Med, 1915; 8 (Sect Epidemiol State Med): 113-94.

16. Haber M, Longini IM Jr, Halloran ME. Measures of the effects of vaccination in a randomly mixing population. Int J Epidemiol, 1991; 20: 300-10.

17. Clemens J1, Brenner R, Rao M, Tafari N, Lowe C. Evaluating new vaccines for developing countries. Efficacy or effectiveness? JAMA, 1996; 275(5): 390-7.

18. Shim E, Galvani AP. Distinguishing vaccine efficacy and effectiveness. Vaccine, 2012; 30(47): 6700-5.

19. Orenstein WA, Bernier RH, Hinman AR. Assessing vaccine efficacy in the field. Further observations. Epidemiol Rev, 1988; 10: 212-41.

20. Fine PE, Clarkson JA. Reflections on the efficacy of pertussis vaccines. Rev Infect Dis, 1987; 9: 86683.

21. Fine PE. Implications of different study designs for the evaluation of acellular pertussis vaccines. Dev Biol Stand, 1997; 89: 123-33. 
22. dos Santos Silva I. Cancer epidemiology: principles and methods. Geneva, Switzerland. International Agency for Research on Cancer, World Health Organization, 1999.

23. Cherry JD, Olin P. The science and fiction of pertussis vaccines. Pediatrics, 1999; 104: 1381-4.

24. Palmer SR. Vaccine efficacy and control measures in pertussis. Arch Dis Child, 1991; 66: 854-7.

25. Lister $S$, Mclntyre $P$, Burgess $M$, O'Brien ED. Immunisation coverage in Australian children: a systematic review. Commun Dis Intell, 1999; 23: 145-70.

26. Mühlemann K, Weiss NS. Can herd immünity influence the assessment of vaccine efficacy in nonrandomized studies? Am J Public Health, 1997; 87: 113.

27. Lone NI, Simpson C, Kavanagh K, Robertson C, McMenamin J, Ritchie L, et al. Seasonal Influenza Vaccine Effectiveness in the community (SIVE): protocol for a cohort study exploiting aunique national linked data set. BMJ Open, 2012; 2(2): e001019.

28. Galloway $Y$, Stehr-Green P, McNicholas A, O'Hallahan J. Use of an observational cohort study to estimate the effectiveness of the New Zealand group B meningococcal vaccine in children aged under 5 years. Int J Epidemiol, 2009; 38(2): 413-8.

29. Mahamud A, Kamadjeu R, Webeck J, Mbaeyi C, Baranyikwa MT, Birungi J, et al. Effectiveness of oral polio vaccination against paralytic poliomyelitis: a matched case-control study in Somalia. J Infect Dis, 2014; 210 (Suppl 1): 187-93.

30. Richard JL, Zwahlen M, Feuz M, Matter HC; Swiss Sentinel Surveillance Network. Comparison of the effectiveness of two mumps vaccines during an outbreak in Switzerland in 1999 and 2000: a case-cohort study. Eur J Epidemiol, 2003; 18(6): 569-77.

31. Hennessy S, Liu Z, Tsai TF, Strom BL, Wan CM, Liu $\mathrm{HL}$, et al. Effectiveness of live-attenuated Japanese encephalitis vaccine (SA14-14-2): a case-control study. Lancet, 1996; 347(9015): 1583-6.

32. Hak E, Wei F, Grobbee DE, Nichol KL. A nested case-control study of influenza vaccination was a cost-effective alternative to a full cohort analysis. J Clin Epidemiol. 2004; 57(9): 875-80.
33. Orenstein WA, Bernier RH, Dondero TJ, Hinman AR, Marks JS, et al. Field evaluation of vaccine efficacy. Bull World Health Organ, 1985; 63: 1055-68.

34. Broome CV, Facklam RR, Fraser DW. Pneumococcal disease after pneumococcal vaccination: an alternative method to estimate the efficacy of pneumococcal vaccine. N Engl J Med, 1980; 303(10): 549-52.

35. Crépey P, de Boer PT, Postma MJ, Pitman R. Retrospective public health impact of a quadrivalent influenza vaccine in the United States.Influenza Other Respir Viruses, 2015; 9 (Suppl 1): 39-46.

36. Valenciano M, Kissling E, Ciancio BC, Moren A. Study designs for timely esti-mation of influenza vaccine effectiveness using European sentinel practitioner networks. Vaccine, 2010; 28(46): 7381-8.

37. Martínez-Baz I, Martínez-Artola V, Reina G, Guevara M, Cenoz MG, Morán J. at al. Effectiveness of the trivalent influenza vaccine in Navarre, Spain, 2010-2011: a population-based test-negative case-control study. BMC Public Health, 2013; 191(13): 1-8.

38. Savulescua C, Jiménez-Jorgea $S$, Delgado-Sanza C, Mateoa S, Pozoc F, Casas I, et al. A Higher vaccine effectiveness in seasons with predominant circulationof seasonal influenza $A(\mathrm{H} 1 \mathrm{~N} 1)$ than in $\mathrm{A}(\mathrm{H} 3 \mathrm{~N} 2)$ seasons: Test-negativecase-control studies using surveillance data, Spain, 2003-2011. Vaccine, 2014; 32: 4404-4411.

39. Chenga AC, Kotsimbosa T, Kelly HA, Irving LB, Bowler SD, Brown SG, et al. Effectiveness of H1N1/09 monovalent and trivalent influenza vaccines against hospitalization with laboratoryconfirmed H1N1/09 influenza in Australia: A testnegative case control study. Vaccine, 2011; 29: 7320-5.

40. Flannery B, Thaker SN, Clippard J, Monto AS, Ohmit SE, Zimmerman RK, et al. Interim Estimates of 2013-14 Seasonal Influenza Vaccine Effectiveness - United States, February 2014. MMWR Morb Mortal Wkly Rep, 2014; 63(7) :137-42. 
41. Galanis E, Mak S, Otterstatter M, Taylor M, Zubel $M$, Takaro TK, et al. The association between campylobacteriosis, agriculture and drinking water: a case-case study in a region of British Columbia, Canada, 2005-2009. Epidemiol Infect, 2014; 142(10): 2075-84.

42. Zenner D, Janmohamed K, Lane C, Little C, Charlett A, Adak GK, et al. The serotype casecase design: a direct comparison of a novel methodology with a case-control study in a national Salmonella Enteritidis PT14b outbreak in England and Wales. Epidemiol Infect, 2013; 141(11): 2346-53.

43. Farrington CP. Estimation of vaccine effectiveness using the screening method.Int J Epidemiol, 1993; 22(4): 742-6.

44. Ivers LC, Hilaire IJ, Teng JE, Almazor CP, Jerome JG, Ternier R, et al. Effectiveness of reactive oral cholera vaccination in rural Haiti: a case-control study and bias-indicator analysis. Lancet Glob Health, 2015; 3(3) :e162-8.

45. Penny MA, Verity R, Bever CA, Sauboin C, Galactionova K, Flasche S, et al. Public health impact and cost-effectiveness of the RTS,S/ AS01 malaria vaccine: a systematic comparison of predictions from four mathematical models. Lancet, 2015 Nov 5. doi: 10.1016/S01406736(15)00725-4.

46. White MT, Verity R, Churcher TS, Ghani AC. Vaccine approaches to malaria control and elimination: Insights from mathematical models. Vaccine, 2015; 33(52): 7544-50.
47. Scott N, McBryde E, Vickerman P, Martin NK, Stone $\mathrm{J}$, Drummer $\mathrm{H}$, et al. The role of a hepatitis $\mathrm{C}$ virus vaccine: modelling the benefits alongside directacting antiviral treatments. BMC Med, 2015; 13 : 198.

48. Ultsch B, Damm O, Beutels P, Bilcke J, Brüggenjürgen B, Gerber-Grote A, et al. Methods for Health Economic Evaluation of Vaccines and Immunization Decision Frameworks: A Consensus Framework from a European Vaccine Economics Community. Pharmacoeconomics, 2015 Oct 17. doi: $10.1007 / s 40273-015-0335-2$.

49. Biggerstaff $M$, Reed C, Swerdlow DL, Gambhir $M$, Graitcer S, Finelli $L$, et al. Estimating the potential effects of a vaccine program against an emerging influenza pandemic--United States. Clin Infect Dis, 2015;60 (Suppl 1): 20-9.

50. Milne GJ, Halder N, Kelso JK, Barr IG, Moyes J, Kahn K, et al. Trivalent and quadrivalent influenza vaccination effectiveness in Australia and South Africa: results from a modelling study. Influenza Other Respir Viruses, 2015 Dec 12. doi: 10.1111/ irv. 12367.

51. Drolet M, Laprise JF, Boily MC, Franco EL, Brisson $M$. Potential cost-effectiveness of the nonavalent human papillomavirus (HPV) vaccine. Int J Cancer, 2014;134(9): 2264-8.

52. Weidemann F, Dehnert M, Koch J, Wichmann O, Höhle M. Modelling the epidemiological impact of rotavirus vaccination in Germany--a Bayesian approach. Vaccine, 2014; 32(40): 5250-7. 


\title{
Mantar enfeksiyonlarının serolojik tanısı
}

\section{Serological diagnosis of fungal infections}

\author{
Asuman BíRiNCi ${ }^{1}, \quad$ Yeliz TANRIVERDi-ÇAYCI ${ }^{1}$
}

\begin{abstract}
ÖZET
İnvaziv mantar hastalıklarının tanısında, günümüzde kullanılan yöntemlerin duyarlılık ve özgüllüğündeki yetersizlikler veya klinik olarak yararlı olabilecek bir sonucun elde edilmesinin çok zaman alması nedeniyle zorluklar yașanmaktadır. Hasta sonuçlarında, hızı tanı anahtar noktadır. Kültür testleri dıșında, konaktaki özgül antikor yanıtının ölçülmesine dayalı serolojik testlerin, hızlı uygulanabilmesi ve invaziv örnek alım yöntemleri gerektirmemesi bu testleri çekici kılmaktadır. Ancak özellikle immünsupresif durumlar nedeniyle, özgül antikor yanıtı olușturamayan hastalarda bu testler her zaman invaziv hastalık belirteci olmamaktadır. Mikrobiyal antijenlerin tespitinin ise genellikle daha fazla miktarda mikrobiyal yük gerektirmesi duyarııığını kısıtlamaktadır. Yine de çok sayıda başarıyla çalıșan antijen tespit sistemleri geliștirilmiștir ve bunların bazıları halen yaygın olarak kullanılmaktadır. Dolașımdaki Aspergillus galaktomannanlarını tespit için sıçan monoklonal EBA2'leri kullanan emzim immünoassay yöntemi (Platelia) ticari olarak kullanımdadır. Bu test 0,5-1,0 ng/ml düzeyindeki galaktomannanı tespit edebilmektedir. Ayrıca, galaktomannan klinik belirti ve semptomlar olușmadan invaziv aspergillozun erken safhalarında serumda tespit edilebilmektedir. Ancak, bu testin yanlış pozitif veya negatif sonuçlar gibi dezavantajları bulunmaktadır. (1,3)-B-D-glukan Zygomycetes'ler hariç mantar hücre duvarının karakteristik bir birleșenidir. Invaziv enfeksiyonlar sırasında Aspergillus, Candida, Fusarium, Trichosporon, Saccharomyces, Acremonium ve Pneumocyctis jirovecii içeren birçok mantar tarafından (1,3)-B-D-glukan kana salınmaktadır.
\end{abstract}

\section{ABSTRACT}

Difficulties are being faced in the diagnosis of invasive fungal diseases due to the lack of sensitivity and specificity of the current diagnostic methods or taking too long time to get a result having clinical importance. Rapid diagnosis is the key point in patient outcomes. Excluding the culture tests, because of its rapid application and no need for invasive sampling, was making the serological tests based on the measurement of response of specific host antibody became attractive. However especially due to immünosuppressive conditions, these tests are not always the indicator of invasive disease in the patients who have no ability to produce specific antibody response. Detection of microbial antigens generally requiring a relatively large microbial burden, limits the assay sensitivity. Nonetheless, several examples of successful antigen detection systems have been developed, and some of these are widely used. To detect circulating Aspergillus galactomannans enyzme immünoassay (Platelia) method utilizing the rat monoclonal antibody EB-A2 is commercially in use. This test is able to detect galactomannan in the level of $0.5-1.0 \mathrm{ng} / \mathrm{ml}$. Furthermore, galactomannan could be detected in the serum at a early stage of invasive aspergillosis before clinical signs and symptoms occured. However, this test has some disavantages like false positive or negative results. (1.3)-B-D-glucan is a characteristic cell-wall component of fungi except for Zygomycetes. A broad range of fungi including Aspergillus, During invasive infections (1.3)-B-D-glucan is released to the blood by some fungi containing Aspergillus, Candida, Fusarium, Trichosporon, Saccharomyces,

Ondokuz Mayıs Üniversitesi, Tıp Fakültesi, Tıbbi Mikrobiyoloji ABD, SAMSUN

\begin{tabular}{|c|c|}
\hline \multicolumn{2}{|l|}{ İletişim/Corresponding Author : Asuman BİRINCİ } \\
\hline Ondokuz Mayıs Üniversitesi, Tıp Fakültesi, Tıbbi Mikrobiyoloji ABD, SAMSUN & Geliş Tarihi / Received : 06.02.2015 \\
\hline E-posta / E-mail : abirinci@omu.edu.tr & Kabul Tarihi / Accepted : 23.10.2015 \\
\hline
\end{tabular}

DOI ID : 10.5505/TurkHijyen.2016.74418

Birinci A, Tanrıverdi-Çaycı Y. Mantar enfeksiyonlarının serolojik tanısı. Turk Hij Den Biyol Derg, 2016; 73(2): 175-82. 
(1,3)-B-D-glukan konsantrasyonunun belirlenmesinde kullanılan yöntem, atnalı (horsecrab shoe) yengecinin koagülasyon faktörü olan faktör G'nin glukanı aktifleștirmesine dayanmaktadır. Hem Avrupa'da hem de ABD'de (1,3)-B-D-glukan için çeșitli ticari kitler kullanımdadır. Mannan invaziv kandidiyazisi bulunan hastalarda dolașımdaki ana antijendir. Mannana karșı oluşan antikorların tespiti için birçok serolojik test bulunmaktadır. Ancak bu testler, kolonizasyon ve invaziv enfeksiyon ayrımında başarısız olmaktadır. Mannan antijeniyle kombine edilip çalıșıldığında, duyarııık \%80 ve özgüllük \%93 olmaktadır. Kriptokokkal enfeksiyonların tespitinde serebrospinal sıvıdan veya serumdan kapsüler antijen tespiti kullanılmaktadır. Kapsüler antijen tespiti için hem lateks aglütinasyon hem de enzimimmünoassay testleri bulunmaktadır. Mantar enfeksiyonlarının tanısı için son yıllarda hızla ilerleme kaydedilerek, mantar enfeksiyonlarının erken tespitini sağlayan birçok yeni yöntem geliștirilmiștir. Ancak en iyi yaklaşımın kültür veya mikroskopi gibi konvansiyonel yöntemlerle serolojik yöntemlerin kombine edilmesi olduğu düșünülmektedir.

Anahtar Kelimeler: Mantar enfeksiyonları, galaktomannan, (1-3)- B -D-glukan, mannan
Acremonium and Pneumocyctis jirovecii. The method used for determination of (1.3)-B-D-glucan concentration depends on activation of glucan by factor G, a horsecrab shoe coagulation factor. There are some commercial test kits available for (1.3)-B-D-glucan both in Europe and USA.Mannan is the major circulating antigen in patients who have invasive candidiasis. There are several serological tests for the detection of antibodies formed against mannan. However, these tests are usually failed in discriminating between colonization and invasive infection. When combination with mannan antigen test was performed, it gave sensivity of $80 \%$ and specifity of $93 \%$. In the diagnosis of cryptococcal infections detection of capsular antigen in the both cerebro-spinal fluid or serum, is used. Both latex aglutination and enzymeimmünoassay tests are found to detection of capsular antigen. The diagnosis of fungal infections has moved forward in the past few years and there are many newly developed methods that are likely to provide early detection of fungal infections. However, it seems that best approach is combining both traditional methods like culture or microscopy with serological methods.

Key Words: Fungal infections, galactomannan, (1-3)- B -D-glucan, mannan

\section{GíRiş}

Son yıllarda mantar enfeksiyonlarının sıklığında ciddi bir artış mevcuttur. Bu enfeksiyonların erken ve doğru tanısı hem antifungal tedaviye zamanında başlanması açısından hem de gerekli değilse başlanmış olan antifungal ajanların kesilerek toksik etkilerinin en aza indirilmesi açısından önemlidir. Fungal etkenlerin tanısında standart olarak kullanılan yöntemler; direk mikroskopi, histopatolojik inceleme ve kültür yöntemleridir. Ancak bu yöntemler kimi zaman yeterli duyarlılığa ve/veya özgüllüğe sahip olmadıklarından kimi zaman da örnekler için invaziv işlemler gerektirdiklerinden tanı açısından yeterli olamamaktadirlar. $\mathrm{Bu}$ nedenle invaziv mantar enfeksiyonlarının tanısında bu yöntemler dışında farklı tanı yöntemlerinede ihtiyaç duyulmaktadır $(1,2)$.
Mantar enfeksiyonlarının tanısında kültür bazlı olmayan serolojik testler geçen yüzyılın ortalarından beri kullanılmaktadır. Seroloji endemik mikozların tanısında oldukça önemli bir parametredir. Mantar enfeksiyonlarının tanısında kullanılan serolojik yöntemler arasında immünodifüzyon (ID), lateks aglütinasyon (LA), kompleman fiksasyon (KF), enzimimmünoassay (EIA) ve radyoimmünoassay (RAI) yer almaktadır (1, 3). Serolojik testlerin kullanımı invaziv mantar enfeksiyonlarının tanısında birçok avantaj sağlamaktadır. Bu avantajlardan biri kültür için örnek alınamadığı veya kültürde üreme gözlenmediği durumlarda pozitif serolojik testlerin yardımcı olmasıdır. Diğer bir avantajı da Coccidiodes türleri gibi çalıșılması dikkat gerektiren mantarlar için 
kültür gereksinimini azaltmalarıdır. Ayrıca serolojik testlerin minimal invaziv testler olmaları hastalar açısından kolaylık sağlamaktadır. Ancak serolojik testlerin bazı dezavantajları da bulunmaktadır. Bu dezavantajlardan bazıları; düşük duyarlılık ve özgüllük, bazı testlerin zaman alıcı olması, deneyimli personel tarafından çalıșılma zorunluluğu, immün sistemi baskılanmıș olan hastalarda antikor testlerinden yeterli verim alınamaması ve fungal etkenler arasındaki çapraz reaksiyonlardır. Ayrıca bir serolojik testin negatif olması mantar enfeksiyonu varlığını ekarte ettirememektedir (3).

Bu derlemede özellikle mantar enfeksiyonlarının serolojik tansında yaygın olarak kullanılan galaktomannan, (1-3)- B-D-glukan, mannan ve glukuronoksilomannan saptanmasına yönelik testler üzerinde durulmuștur.

Mantar Enfeksiyonlarının Serolojik Tanısında Kullanılan Antijenler

\section{Galaktomannan}

Galaktomannan (GM) birçok Aspergillus türünün hücre duvarında bulunan bir polisakkarittir. İnvaziv aspergilloz enfeksiyonlarının tanısında uzun yıllar LA, EIA ve RAl olmak üzere farklı serolojik yöntemlerle, insan vücut sıvılarında galaktomannan antijeni araștırımıștır (4). Ancak bu testlerin rutin kullanımı, tespit sınırlarının yüksek değerler $(5-15 \mathrm{ng} / \mathrm{ml})$ olmasından dolayı kısıtlı kalmıştır. Çünkü bu ölçüm değerleri ancak hastalığın ilerlemiş dönemlerinde oluşmakta ve bu dönemde antifungal tedavinin etkinliği de sınırlı kalmaktadır (1). Sytenen ve ark. (5) sıçan monoklonal EB-A2 antikorlarının kullanarak serum örneğinde, dolaşımdaki galaktomannan antijenlerini saptayan sandviç ELISA yöntemini geliştirmişlerdir. $\mathrm{Bu}$ testte tespit sınırı eski yöntemlerden yaklaşık 10-15 kat düşük olacak șekilde $0,5-1 \mathrm{ng} / \mathrm{ml}$ 'dir. Bu yöntemde pozitiflik galaktomannan LA testinden daha erken saptanmakta ve LA testi negatifleșse bile hala pozitif kalmaktadır. Test, 1997 yılında ticari olarak Platelia Aspergillus $₫(B i o R a d$ Laboratories, İngiltere) adıyla piyasa sürülmüș ve 2003 yılında da Amerika İlaç Dairesi (FDA)'nden onay almıștır (5). Illk piyasaya sürüldüğünde testin eșik değeri $1,5 \mathrm{ng} / \mathrm{ml}$ iken, daha sonra $0.5 \mathrm{ng} / \mathrm{ml}$ olarak değiștirilmiștir. Test sonuçları galaktomannan indeksi (GMi) ya da optik dansite indeksi (ODi) olarak rapor edilmektedir. Haftada iki serum örneğinin çalıșılması önerilmekte, üst üste gelen iki örnekte pozitiflik olması durumunda invaziv aspergilloz açısından anlamlı kabul edilmektedir (6).

Deney hayvanlarıyla yapılan bazı çalıșmalarda GM antijenemisinin derecesi ile dokudaki fungal yük arasında doğru orantı olduğu bildirilmiștir $(2,4)$. Allojenik kök hücre nakli yapılmıș 100 hastada GM saptanmasının invaziv aspergillozun erken tanısındaki etkisi araștırılmıș ve hastaların \%83'ünde antifungal tedavinin erken bașlamasını sağlamıștır (2). Ancak farklı eșik değerlerin kullanılması bu testle ilgili olarak kafa karıștırıcı sonuçlara neden olmuștur. Kanser hastalarında yapılan, eșik değeri >1,5 GMi olarak kabul eden ve tek bir örnek sonucunu pozitif olarak değerlendiren bir çalıșmada duyarılıı \%26,1 olarak bulunmuștur. Eșik değeri >0,7 GMi'ye indirmek duyarılıı̆ı \%50'ye çıkarmıștır (7). Eșik değerin 1,5'ten 0,5 GMi'ye çekilmesi erken tanı açından da önemlidir. Eșik değer, 0,5 GMi'ye çekilince 6 gün daha erken tanı konulduğu saptanmıștır (8).

Yapılan çalıșmalarda yanlış negatif sonuçların nedeni olarak anti-Aspergillus antikorların varlığı, enfeksiyonun lokalizasyonu ve sınırlı bir alanda olması, Aspergillus türleri arasında GM sentez ve salıverilmesindeki farklııklar ve GM dolașımının sürekli olmaması üzerinde durulmuștur. Serumların saklanma koșulları da yanlıș negatiflik etkenidir. Ayrica ampirik veya profilaktik olarak antifungal tedavi uygulanması yanlıș negatif sonuçlara neden olabilmektedir (2).

GM testi için yanlış negatiflik yanında bir diğer sorun da yanlıș pozitif sonuçlara neden olabilmesidir. GM sütte ve tahıllarda da bulunmaktadır ve özellikle kemoterapiye bağlı mukozit nedeniyle intestinal mukozası zarar görmüș kișilerde, tahıllarla 
beslenme sonrasında yanlıs pozitif sonuçlara neden olabilmektedir. Ayrıca süt ağırlıklı olarak beslenen pediatrik yaș grubundaki hastalarda da yanlıs pozitif sonuçlar görülebilmektedir. Piperasilin-tazobaktam, ampisilin-sulbaktam, amoksisilin-klavulonik asit gibi mantar kökenli antibiyotiklerin kullanıldığı hastalarda da yanlış pozitiflikler görülebilmektedir $(9,10)$. Ayrıca diğer fungal etkenlerle (Penicillium spp., Acremonium spp., Rhodotorula rubra, Geotrichum capitatum, Cladosporium spp., Botritistulupae, Fusarium oxisporum, Paecilomyces variotii, Wallemia) enfeksiyon ve immünoglobulinler ile siklofosfamit gibi immün sistem, baskılayıcı ajanların kullanımı da yanlıș pozitifliklere neden olmaktadır (2).

Invaziv aspergilloz tanısında bronkoalveolar lavaj (BAL) sıvısında da GM araștırılabilmektedir. Ağca ve ark. çalışmalarında, GMi değerleriyle, bronkoalveolar lavaj ve bronșial lavaj kültür pozitiflikleri karşılaștırılmış ve GM testinin erken tanıya katkı sağladığı ve eğer $G M I \geq 1$ ise kültürde fungal üremenin beklenebileceğini belirtmişlerdir (11). Solid organ transplantasyonu yapılmış 81 hastanın, BAL örneğinde GM araștırılmıș ve bu çalıșmada GM eșik değeri $\geq 1$ olduğu zaman duyarlılık \%100 ve özgüllük \%90,8 olarak saptanmıștır ve BAL GM testinin, serum GM ve BAL sitoloji ve kültüründen daha iyi sonuç verdiği bildirilmiștir. Ancak akciğer transplantasyonu yapılmış olan 12 hastanın beșinde yanlış pozitif sonuç elde edilmiş, bunun nedeni olarak da bu hasta grubunun transplantasyondan önce solunum yollarının Aspergillus spp. türleri ile kontamine olmuş olabileceği belirtilmiștir. Akciğer transplantasyonu yapılan hastalar çıkartıldığında özgüllüğün \%92,9'a yükseldiği görülmüștür (12). Fisher ve ark.'nın çalıșmasında invaziv pulmoner aspergillozda serum ve BAL'da galaktomannan araștırılmasının erken tanıyı artırdığı ve BAL'daki galaktomannan değerinin antifungal tedaviden etkilenmediğini belirtilmiștir (13). BOS'da GM ile ilgili fazla çalıșma bulunmamakla beraber BOS'da indeks değer olarak >0,5 GMi kabul edilmesinin santral sinir sistemi (SSS) aspergillozu lehine değerlendirilebileceği bildirilmiștir (14).
(1-3)- B -D-glukan

(1-3)- B-D-glukan (BG), Zygomycetes’ler hariç birçok mantar türünün hücre duvar yapısında bulunan non-allerjenik, suda çözülebilir bir polisakkarittir. Aspergillus, Candida, Fusarium, Trichosporon, Saccharomyces, Acremonium ve Pneumocyctis jirovecii'nin neden olduğu invaziv fungal enfeksiyonlarda kana salınmaktadır. Nötrofil, makrofaj ve kompleman aktivasyonu yapmaktadır. BG, Cryptococcus türleri ve Mucorales ile enfekte hastaların kanında saptanmamaktadır $(2,3)$. Kanda BG tespiti, atnalı (horseshoe) yengeçlerinden elde edilen faktör G'yi, BG'nin aktive etmesiyle birlikte bir koagülasyon kaskatını başlaması ve bu reaksiyonların türbidometrik veya kolorimetrik bir yöntemle tespitine dayanmaktadır $(3,15)$. BG tespitine yönelik çeșitli ticari kitler de kullanıma sunulmuștur: B-Dglucan Test (Wako Pure Chemical Industries, Tokyo, Japonya), Fungi Tec (Seikagaku Kogyo Corporation, Tokyo, Japonya), BG-Star (Maruha Corporation, Tokyo, Japonya), Glucatell (Fungitell, Associates of Cape Cod, Falmouth, ABD). Bunlardan, Fungitell testinin FDA onayı bulunmakta ve serum, BAL ve plazma örneklerinden çalıșılabilmektedir. Bu test için üretici tarafından belirtilmiş eşik değerler, $>80 \mathrm{pg} / \mathrm{ml}$ : pozitif, 60-79 pg/ml: ara değer ve $<60 \mathrm{pg} / \mathrm{ml}$ : negatif'tir (16). Bu testin en büyük avantajı 1 saat gibi kısa bir sürede sonuç verilebilmesidir. Bu testin immün sistemi baskılanmıș hastalarda haftada en az iki kez çalıșılması önerilmiş ve üst üstte iki örneğin pozitif olmasının invaziv mantar enfeksiyonu lehine anlamlı olduğu belirtilmiştir (17). Ancak bu testte diğer birçok testte olduğu gibi kısıtlayıcı yönler bulunmaktadır. Testin çalıșılması sırasında endoktoksin ve glukan içeren cam malzemelerin kullanılmaması gerekmektedir. Ayrıca hemodiyaliz hastalarında kullanılan sellüloz membranlar, cerrahide kullanılan gazlı bezler, i.v. albumin veya gama globulin kullanımı, bakteriyemi yanlış pozitif sonuçlara neden olabilmektedir (18). Ayrıca BG testinin pahalı bir test olması ve panfungal bir test olduğu için etkeni tam olarak belirleyememesi, testin kısıtlayıcı yönleri arasındadır. 
Kanıtlamıș invaziv fungal enfeksiyonu olanlarda BG için eșik değer $>60 \mathrm{pg} / \mathrm{ml}$ olarak kabul edildiğinde kandidoz, aspergilloz ve fusaryoz enfeksiyonu olanlarda duyarlılık sırasıyla $\% 81,3, \% 80$ ve $\% 100$ olarak saptanmıș ve BG'nin profilaktik antifungal tedaviden etkilenmediği görülmüştür (2). İnvaziv mantar enfeksiyonu olan (kandidoz, aspergilloz, fusaryoz, trikosporonoz) akut myeloblastik lösemi hastalarında BG, klinik tanıdan ortalama 10 gün önce pozitif olarak saptanmış ve negatif prediktif değer $\% 100$, özgüllük \%90 olarak saptanmıştır (19). Ancak Metan ve ark.'nın çalıșmasında otolog hematopoetik kök hücre nakli yapılan 79 hastanın serum örneği BG açısından taranmış ve duyarlıık \%27,2, özgüllük $\% 94,4$, pozitif prediktif değer $\% 6,2$ ve negatif prediktif değer \%93,7 olarak saptanmıștır ve bu hasta grubunda BG taramasının kliniğe katkısının sınırlı olduğunu belirtilmiștir (20).

P. jirovecii enfeksiyonu olan 9 hastanın hepsinde BG pozitif olarak saptanmış ve BG düzeyinin tedavi ile azaldığı görülmüştür (21). Beta glukan testinin kan dişındaki vücut sıvılarında durumunu değerlendiren fazla çalıșma olmamakla birlikte mevcut verilerle test ümit vaat etmektedir. Daha geniş çaplı ileriye yönelik araștırmalara ihtiyaç duyulmaktadır.

\section{Mannan}

Mannan, Candida türlerinin hücre duvarında bulunan polisakkarit yapıda, yüksek immünojenik özellikte bir antijendir ve immünolojik olarak B-glukandan daha aktiftir. Isıya, kaynatmaya, proteinaz etkisine ve asidik pH'a dirençlidir. Kan kültürlerinin pozitifleșmesinden 2-15 gün öncesinde pozitif sonuç alınabilmektedir. Mannan antijeni invaziv kandidozu olan hastalarda kana salınmaktadır. Ticari olarak mannan tespitine yönelik ELISA ve LA temelli testler mevcuttur. ELISA testlerinde duyarlıı̆̆ın 10 kat fazla olduğu bildirilmiștir. ELISA testi olarak Platelia Candida Antibody Test (BioRad, Redman, ABD) kullanımda olan bir testtir. Bu testte sınır değer $10 \mathrm{AU} / \mathrm{ml}$ 'dir. Ancak nötropenik olmayan hastalarda duyarlılığı düşük olarak bulunmuștur (22). Serum dışında diğer klinik örneklerle yapılan çalıșmalar sınırlıdır. Testin duyarlılığı türlere göre değişmektedir. Duyarlılık; C. albicans, C. glabrata, C. tropicalis türlerinde \%58-70 olarak bildirilirken, C. parapsilosis, C. krusei C. kefyr türlerinde ise \%25-30 olarak bulunmuștur. Kandidemisi olan 56 hastanın dahil olduğu bir çalıșmada C. parapsilosis ve C. guilliermondii türlerinde testin bașarısız olduğu saptanmıștır (22). Duyarlılıklar arasındaki farkın testte kullanılan monoklonal antikorların (Mab) Candida türlerinin mannoz epitoplarına bağlanmasındaki farktan kaynaklandığı düşünülmektedir (23). Mannan dolaşımdan çok hızlı temizlendiği için serum konsantrasyonları düşüktür. Bu nedenle birden fazla serum örneğinde çalıșılması önerilmektedir. Tek serum örneği ile değerlendirme yapılan çalıșmalarda duyarlıık \%11'e kadar düşebilmektedir. Enfeksiyonu olmayan ancak kandida ile kolonize olmuş olan hastaların serumlarında da anti-mannan antikorları tespit edilebilmektedir. Bu nedenle, kolonizasyon ve invaziv hastalık ayırımında yararlı olamamaktadır (24). Ancak ardışık testlerde antikor titrelerinin artmasının enfeksiyon/kolonizasyon ayrımında yararlı olabileceği bildirilmiștir. Ayrıca, antikor ve antijen testlerinin birlikte kullanımının daha yararlı olacağı belirtilmiştir (25). Invaziv kandidoz tanısında mannan antikor ve antijenlerinin ELISA yöntemiyle çalıșıldığı 14 çalışma incelendiğinde duyarlıık ve özgüllük sırasıyla; sadece mannan antijeni kullanıldığında \%58 ve $\% 93$, mannan antikoru kullanıldığında $\% 59$ ve $\% 83$, kombine mannan antikoru/antijeni kullanıldığında $\% 83$ ve $\% 86$ olduğu görülmüștür (26).

\section{Glukuronoksilomannan}

Kriptokokkal menenjitin tanısında uzun yıllardır antijen testleri kullanılmaktadır. Lateks aglütinasyon testinde kapsüler bir polisakkarit olan glukuronoksilomannan (GXM) antijenini tespit edilmektedir. Kriptokokkal menenjit sırasında GXM yoğun miktarda hem kan hem de beyin omurilik sivisinda (BOS) bulunmaktadır (3). 
Kriptokokkal menenjit tanısında, lateks aglütinasyon ile antijen tespitinin, mikroskobi ve kültür yöntemleri ile karșılaștırılmasında duyarlılık sırasıyla \%91,1, \%73,2 ve \%69,9; özgüllük ise \%96,0, $\% 100$ ve $\% 100$ olarak tespit edilmiș ve antijen tespitinin konvansiyonel yöntemlere göre erken ve hızlı tanı sağladığı belirtilmiștir (27). Kriptokok kapsüler antijenine karșı poliklonal IgG antikorları kullanan lateks aglütinasyon testlerinde yalancı pozitif sonuçlar olușabilmektedir. Ayrıca romatoid faktör, sistemik trikosporonoz, Capnocytophaga canimorsus septisemisi ve malignensilere bağlı olarak da yanlıș pozitif sonuçlar bildirilmiștir. Ancak bu yanlıș pozitiflikler sıklıkla prozon benzeri etki sonucu olușmakta ve örneğin dilüsyonu ile önlenebilmektedir (19). Fare kökenli monoklonal lgM kullanan Murex Cryptococcus testi (Murex Diagnostic, Galler) romatoid faktöre bağlı olarak olușan yanlıș pozitiflik sorununu ortadan kaldırmıștır ancak bu testin duyarlılığı tavșan kökenli poliklonal IgG kullanılan testlere göre daha düșük olarak bulunmuștur (28). Başka bir testte ise EIA yöntemi kullanılmıștır. Bu testtin (PREMIER Crytococcal antijen testi, Meridian Diagnostic) serum ve BOS için duyarlılığı ve özgüllüğü lateks aglütinasyon testlerine benzerdir. Bu testin lateks aglütinasyonlarına göre en önemli avantajı romatoid faktörle reaksiyona girmemesi, yanlış pozitif sonuçların daha az olması ve çok sayıda örneğin çalıșılabilmesine imkan sağlamasıdır (29).

C. neoformans antijen tespitinde son yıllarda kullanıma giren bir dipstick testi olan $\mathrm{Cr}$ Ag lateral flow immünoassay (LFA) özellikle kısıtlı imkanlara sahip kurumlarda kullanım kolaylığı getirmiștir (3).

\section{Diğer testler}

İnvaziv kandidozun tanısında kullanılmak üzere geliștirilen bir test de 230-250 kDa'luk germ tüp mannoproteininin tespitine yönelik indirekt immünofloressan bir test olan CAGTA (Candida albicans germ tube antibody) testidir. Bu testin değișik hasta gruplarındaki (intravenöz uyușturucu kullananlar, kemik iliği alıcıları, hematolojik malignensisi olan hastalar ve yoğun bakım hastaları) özgüllüğü \%91-
100 olarak bulunmuștur. C. albicans dıșında diğer kandidalara (C. tropicalis, $C$. parapsilosis, $C$. glabrata, C. dubliniensis, $C$. guillermondii ve $C$. krusei) bağlı olarak olușan invaziv kandidozda da CAGTA sonuçları daha düșük titre de olmakla birlikte pozitif olarak bulunmuștur. Ayrıca CAGTA titrelerindeki azalmanın, invaziv kandidozu olan ve antifungal tedavi alan hastalarda tedaviye yanıtın izlenmesinde de yardımcı olacağı bildirilmiștir. CAGTA tespitine yönelik IFA IgG (Vircell Laboratorie, İspanya) adlı ticari kit geliștirilmiștir. Testler sıklıkla anti-Candida IgG'nin tespitine yönelik olsa da IgM, IgA ve IgE tespitine yönelik testler de kullanılmıştır. Bunlardan özellikle IgA'nın invaziv kandidoz tanısında yararlı bir belirteç olduğu bildirilmiștir (30).

Kandidalarda hücre duvarında değil de sitoplazmada yer alan ve enzimatik aktiviteye sahip enolaz, aspartil proteinaz ve metallo peptidaz gibi antijenlere karșı oluşan antikorları saptamaya yönelik testler de kullanılmıștır. Bu antijenleri saptamaya yönelik ticari kitler henüz bulunmamaktadır. Enolaza karșı olușan antikorların araștırıldığı bir çalıșmada duyarlılık ve özgüllük immün sistemi sağlam bireylerde sırasıyla \%5092 ve \%86-95; immün sistemi baskılanmıș bireylerde ise $\% 53$ ve $\% 78$ olarak tespit edilmiștir (30). C. albicans için önemli bir virulans faktörü olan salgısal aspartil proteinaza (SAP) karșı olușan antikorların araștırıldığı bir çalıșmada invaziv kandidozlu hastalarda duyarlılık \%69,7 ve özgüllük \%76 olarak bulunmuștur $(30,31)$.

Cand-Tec lateks aglütinasyon testi (Ramco Laboratories, Houston, ABD) ssıya duyarlı antijen tespitine yönelik kullanıma giren ilk ticari testtir. Ancak testin duyarlılığı ve özgüllüğü çalıșmalar arasında farklılık göstermektedir ve ayrıca romatoid faktör pozitifliğine bağlı olarak yalancı pozitiflikler de bildirilmiștir $(1,32)$. Bir bașka hedef antijen olan enolazın kandidemili hastalarda serumda bulunurken yüzeyel kolonizasyonu olan hastalarda bulunmadığı tespit edilmiștir. Ancak kandidemi tanısında umut vaat eden bu test, üreticisi (Directigen, Becton Dickenson, ABD) tarafından piyasadan çekilmiștir (1). 


\section{Sonuç}

İnvaziv mantar enfeksiyonlarının sıklığı her geçen yıl giderek artmaktadır. Bu nedenle erken ve doğru tanının konması ve tedaviye başlanması hayati önem tașımaktadır. Ancak laboratuvarlarda yaygın olarak kullanılmakta olan konvansiyonel yöntemler bazen yetersiz kalmaktadır. Yıllar içinde mantar patojenlerinin virulans faktörlerinin ve antijenik determinantlarının tanımlanması invaziv mantar enfeksiyonlarının tanısı için yeni yaklaşımların gelișmesini sağlamıștır. Son yıllarda mantar enfeksiyonlarının tanısında serolojik testler konusunda ilerlemeler kaydedilmiştir. Bu testler kimi zaman tanıya çok yardımcı olsa da, duyarlılık ve özgüllük sonuçları kimi zaman yetersiz kalabilmektedir. Ayrıca bu derlemede de belirtildiği üzere çeșitli faktörlerin de serolojik testleri etkileyebilmesi göz önünde bulundurulmalıdır. Ancak klinik, kültür ve mikroskobik yöntemlerle birlikte serolojik testlerin uygun hasta popülasyonunda ve uygun sıklıkta çalışılmasının invaziv mantar enfeksiyonlarının tanısına katkısının büyük olacağı görünmektedir.

\section{ÇIKAR ÇATIŞMASI}

Yazarlar herhangi bir çıkar çatıșması bildirmemektedir.

\section{KAYNAKLAR}

1. Yeo SF, Wong B. Current status of non culture methods for diagnostics of invasive fungal infetions. Clin Microbiol Rev, 2002; 15: 465-83.

2. McLintock LA, Jones BL. Advances in the molecular and serological diagnosis of invasive fungal infection in haemato-oncology patients. Brith $\mathrm{J}$ Hematol, 2004;126: 289-97.

3. Kozel TH, Wickes B. Fungal Diagnostics. Cold Spring Harb Perspect Med, 2014; doi: 10.1101/ cshperspect.a019299.

4. Verweij PE, Meis JFGM. Microbiological diagnosis of invasive fungal infections in transplant recipients. Transpl Infect Dis, 2000: 2: 80-7.

5. Stynen D, Goris A, Sarfati J, Latge JP. A new sensitive sandwich enzyme-linked immünosorbent assay to detect galactofuran in patients with invasive aspergillosis. J Clin Microbiol, 1995; 33: 497-500.

6. Mennik-Kersten M, Donnelly JP, Verweij P. Detection of circulating galactomannan for the diagnosis and management of invasive aspergilllosis. Lancet, 2004; 4(6): 349-57.
7. Herbrecht R, Letscher-Bru V, Oprea C, Lioure B, Waller J, Campos $\mathrm{F}$ et al. Aspergillus galactomannan detection in the diagnosis of invasive aspergillosis in cancer patients. J Clin Oncology, 2002; 20: 1898-906.

8. Marr KA, Balajee SA, McLaughlin L, Tabouret M, Bentsen C, Walsh TJ. Detection of galactomannan antigenemia by Enzyme Immunoassay for the Diagnosis of invasive Aspergillosis: variables that affect performance. J Infect Dis, 2004; 190(3): 641- 9.

9. Aubry A, Porcher R, Bottero J, Touratier S, Leblanc T, Brethon B et al. Occurrence and Kinetics of FalsePositive Aspergillus Galactomannan Test Results following Treatment with beta-lactam Antibiotics in Patients with Hematological Disorders. J Clin Microb, 2006; 44: 389- 4.

10. Mattei D, Rapezzi D, Mordini N, Cuda F, Nigro C, Musso $M$ et al. False-Positive Aspergillus Galactomannan Enzyme-Linked Immunosorbent Assay Results In Vivo during Amoxicillin-Clavulanic Acid Treatment. J Clin Microb, 2004; 42: 5362-3.

11. Ağca $H$, Ener $B$, Yılmaz E, Ursavas A, Kazak E, Özkocaman $V$ et al. Comparative evaluation of galactomannan optical density indices and culture results in bronchoscopic specimens obtained from neutropenic and non-neutropenic patients. Mycoses, 2014; 57: 169-75. 
12. Clancy CJ, Jaber RA, Leather HC, Wingard JR, Staley B, Wheat LJ et al. Bronchoalveolar Lavage Galactomannan in Diagnosis of Invasive Pulmonary Aspergillosis among Solid-Organ Transplant Recipients. J Clin Microbiol, 2007; 45(6): 1759-65.

13. Fisher CE, Stevens AM, Leisenring W, Pergam SA, Boeckh M, Hohl TM. Independent contribution of bronchoalveolar lavage and serum galactomannan in the diagnosis of invasive pulmonary aspergillosis. Transpl Infect Dis, 2014; 16: 505-10.

14. Cuenca-Estrella M, Bassetti M, Lass-Flörl C, Racil Z, Richardson M, Rogers TR. Detection and investigation invasive mold disease. J Antimicrob Chemother, 2011; 66: 15-24.

15. Miyazaki T, Kohno S, Mitsutake K, Maesaki S, Tanaka K, Ishikawa N et al. Plasma (1,3)-B-D-Glucan and Fungal Antigenemia in Patients with Candidemia, Aspergillosis, and Cryptococcosis. J Clin Microbiol, 1995; 33(12): 3115-8.

16. Sulahian A, Porcher R, Bergeron A, Touratier $S$, Raffoux E, Menotti $J$ et al. Use and Limits of $(1,3)-B-D-G l u c a n$ Assay (Fungitell), Compared to Galactomannan Determination (Platelia Aspergillus), for Diagnosis of Invasive Aspergillosis. J Clin Microbiol, 2014; 52(7): 3228-33.

17. Ener B. İnvazif fungal infeksiyonlarda tanisal yaklașım. Ankem Derg, 2013; 27(Ek2): 141-3.

18. Stevens DA. Diagnosis of fungal infectons: current status. J Antimicrob Chemother, 2002; 49: 11-4.

19. Odabasi Z, Mattiuzzi G, Estey E, Kantarjian H, Saeki F, Ridge RJ et al. B-D-Glucan as a Diagnostic Adjunct for Invasive Fungal Infections: Validation, Cutoff Development, and Performance in Patients with Acute Myelogenous Leukemia and Myelodysplastic Syndrome. Clin Infect Dis, 2004; 39: 199-205.

20. Metan G, Koç AN, Kaynar LG, Atalay A, Öztürk A, Eser $B$ et al. What is the role of the $(1,3)$-b-Dglucan assay in the screening of patients undergoing autologous haematopoietic stem-cell transplantation? Mycoses, 2013; 56: 34-8.

21. Koo S, Bryar J, Page JH, Baden LR, Marty FM. Clinical utility of the $(1,3)$-B-D-glucan assay (BG) in the diagnosis of invasive fungal infections (IFI). Program and abstracts of the 46th Interscience Conference on Antimicrobial Agents and Chemotherapy; September 27-30, 2006; San Francisco, California. Abstract M-1600.
22. Held J, Kohlberger I, Rappold E, Grawitz AB, Häcker G. Comparison of $(1,3)-B-D-G l u c a n$, Mannan/antiMannan-antibodies and Cand-Tec Candida-Antigen as Serum Biomarkers for Candidemia. J Clin Microbiol, 2013;45(6):1158- 64.

23. Sendid B, Poiret JL, Tabouret M, Bonnin A, Caillot D, Camus D, et al. Combined detection of mannanaemia and anti-mannan antibodies as a strategy for the diagnosis of systemic infections caused by pathogenic Candida species. J Med Microbiol, 2002; 51: 433- 42.

24. Martínez JP, Gil ML, López-Ribot JL, Chaffin WLJ. Serologic Response to Cell Wall Mannoproteins and Proteins of Candida albicans. Clin Microbiol Rev, 1998; 11(1):121- 41

25. Lopez-Ribot JL, Casanova M, Murgui A, Martinez JP. Antibody response to Candida albicans cell wall antigen. FEMS Immunology and Medical Microbiology, 2004; 41: 187-96.

26. Mikulska $M$, Calandra T, Sanguinetti $M$, Poulain D, Viscoli C, The Third European Conference on Infections in Leukomia Group. The use of mannan antigen and anti-mannan antibodies in the diagnosis of invasive candidiasis: recommendations from the Third European Conference on Infections in Leukomia Group. Critical Care, 2010;14 (R222): 2-14.

27. Wang H, Yuan X, Zhang L. Latex agglutination: Diagnose the early Cryptococcus neoformans test of capsular polysaccharide antigen. Pak J Pharm Sci, 2015; 28 (Suppl): 307-11.

28. Jaye DL, Waites KB, Parker B, Bragg SL, Moser SA. Comparison of two rapid latex agglutination tests for detection of cryptococcal capsular polysaccharide. Am J Clin Pathol, 1999; 109: 634-41.

29. Gade W, Hinnefeld SW, Babcock LS, Gilligan P, Kelly W, Wait K, et al. Comparison of the PREMIER cryptococcal antigen enzyme immüno assay and the latex agglutination assay for detection of cryptococcal antigens. J Clin Microbiol, 1991; 29: 1616-9.

30. Quindós G, Moragues MD, Pontón J. Is there a role for antibody testing in the diagnosis of invasive candidiasis? Rev Iberoam Micol, 2004; 21: 10-4.

31. Ellepola NBA, Morrison CJ. Laboratory Diagnosis of Invasive Candidiasis. The J of Microbiol, 2005;43: 65-84.

32. Burnie JP, Williams JD. Evaluation of the Rameo latex agglutination test in the early diagnosis of systemic candidiasis. Eur J Clin Microbiol, 1998; 5(4): 98-101. 


\section{Dijital PZR ve kullanım alanları}

\section{Digital PCR and applications}

\section{Ahmet ÇARHAN $^{1}, \quad$ Elif ERCAN ${ }^{1}, \quad$ Tuğba YALÇINKAYA ${ }^{1}$}

\section{ÖZET}

Polimeraz zincir reaksiyonu (PZR), DNA kompleks havuzundan spesifik bir DNA parçasını çoğaltmaya olanak sağlayan basit, etkin ve özellikle moleküler biyoloji alanında yaygın olarak kullanılan enzimatik bir tekniktir. PZR tekniğinin keșfinden günümüze kadar gelișen teknolojiyle birlikte pek çok PZR tekniği ortaya çıkmıştır. Bu tekniklerden bazıları Gerçek Zamanlı PZR, Kantitatif PZR, Ters Transkriptaz PZR, Nested PZR ve Multipleks PZR dir. Günümüze kadar geliștirilmiș PZR tekniklerinin çeșitli zorlukları yüzünden PZR tekniklerinin kullanım alanını genișletmek ve daha ileri seviye PZR teknikleri bulmak araștırmacıların birinci önceliği haline gelmiștir. Nadir mutasyonların, kopya sayısı varyasyonlarındaki ufak değișikliklerin, gen ifadesi değişiklikleri arasındaki farklılıkların veya metilasyon durumunun değerlendirilmesine izin veren yeni bir yöntem olarak dijital PZR (dPZR) teknolojisi geliștirilmiștir. Dijital PZR, DNA kopya sayısının hassas ölçümü için PZR bazlı yeni bir tekniktir ve örnekleri az sayıda seyrelterek çok sayıda PZR gerçekleștirmeye olanak sağlar ve her birinde ayrı ayrı PZR gerçekleșen çok sayıda küçük bölümlere sahiptir. Aynı zamanda dPZR; șu an çok az miktardaki genetik materyalin miktarını dakikalar içinde tespit etme performansıyla birçok nicel yöntemleri geride bırakmıștır. Tek molekülü sayma stratejisi sayesinde bu yöntem yüksek hassasiyet gösterebilmektedir. Güvenilirlik ve tekrarlanabilirlik

\section{ABSTRACT}

Polymerase chain reaction (PCR), is a simple, effective and widely used enzymatic technic especially in the field of molecular biology which provides the opportunity to amplify a specific DNA fragment from DNA complex pool. Several PCR techniques such as realtime PCR, quantitative and qualitative PCR, Reverse Transcriptase PCR, Nested PCR and multiplex PCR have been developed since the first invention of PCR. Due to the various difficulties of the PCR techniques developed so far, widening the application fields and finding out more advanced level of PCR techniques have become the first priority of the researchers. Digital PCR (dPCR) technology has been developed as a new method to permit the evaluation of the small changes in the copy number variations of the rare mutations, differences between the gene expression changes or state of methylation. Digital PCR is a PCR based new technique for the sensitive measurement of number of DNA copies, it provides opportunity to do large number of PCR with a few number of sample dilution and it has so many small compartments where seperate PCRs are executed in each. At the same time, $\mathrm{dPCR}$ leaves some of the quantitative methods behind with the performance of determining the quantity of small amount of genetic material within seconds. This method shows high

' Yıldırım Beyazıt Üniversitesi, Tıp Fakültesi, Tıbbi Biyoloji Ana Bilim Dalı, ANKARA

İletişim/Corresponding Author : Ahmet ÇARHAN
$\begin{array}{ccc}\text { Yıldırım Beyazı Üniversitesi, Tıp Fakültesi, Tıbbi Biyoloji Ana Bilim Dalı, ANKARA } & \text { Geliş Tarihi / Received : 12.11.2015 } \\ \text { Tel : }+905058745682 & \text { E-posta/E-mail : ahmet_carhan@hotmail.com } & \text { Kabul Tarihi / Accepted : 25.02.2016 }\end{array}$

DOI ID : 10.5505/TurkHijyen.2016.48902

Çarhan A, Ercan E, Yalçınkaya T. Dijital PZR ve kullanım alanları. Turk Hij Den Biyol Derg, 2016; 73(2): 183-98. 
düzeyi oldukça yüksek bir yöntem olmasıyla da dikkat çekmektedir. Bu derleme, digital PZR yönteminin günümüze kadar olan süreçteki gelișimine ve ilerleyen günlerde çözüm bulunması gereken eksik yönlerine dikkat çekmeyi amaçlamaktadır.

Anahtar Kelimeler: Dijital PZR, Nadir Mutasyon, dMIQE Kuralları sensitivity with the strategy of counting single molecule. It also attracks the attention as a method having quite a high reliability and repeatability level. This review aims to give insight for $\mathrm{APCR}$ development history and the possible difficulties came across in its application.

Key Words: Digital PCR, Rare Mutation, dMIQE rules

\section{GiRiş}

Polimeraz zincir reaksiyonu (PZR) keșfedildiğinden bu yana biyoloji bilimi kökten değișmiștir (1). Bu teknik adını, DNA Polimeraz enzimi kullanılarak DNA'nın bir parçasını in vitro yöntemle çoğaltılmasından almaktadır. PZR sayesinde birkaç farklı düzenlemeyle üretilen DNA parçasının milyonlarca kopyası arasından, istenilen bir DNA parçasının bir tek veya birkaç kopyasını laboratuvar ortamında çoğaltabilmek mümkündür.

PZR genetik ișlemlerin geniș bir yelpazede değiștirebilmesine olanak sağlar (2). Yaygın kullanımı nedeniyle PZR'nin temel prensiplerini, genomun ve genlerin gelișmiș șekilde analizini nasıl modifiye ettiğini anlamak önemlidir (3).

PZR, özellikle moleküler biyoloji alanında yaygın olarak kullanılan bir tekniktir (2). PZR hedefli stratejiler ile İnsan Genom Projesi gibi kapsamlı araștırmalar yürütülmüș, tıbbi alanda da klinisyenler ve araștırmacılar tarafından gen dizileri, hastalıkların teșhisi gibi nitel-nicel ve genomik çalıșmalarda kullanılmıștır. Yöntemin hassas ve hızlı olması büyük avantaj sağlamaktadır. Klasik PZR, mikrobiyolojide patojenlerin tespiti ve adli tıpta suçluların tanımlanması gibi alanlarda da kullanılmaktadır (3).

PZR ile ilgili bilgiler ilk olarak 1985'de rapor bildirilmiștir (4). 1993 yılında, Mullis PZR üzerine çalıșmalarından dolayı Nobel Kimya Ödülü’ne layık görülmüștür. DNA'nın belirli bir parçasını izole etmek için kullanılan tekniklerin zaman alıcı olması nedeniyle PZR yöntemine ihtiyaç duyulmuștur. Diğer bilim adamları da sınırsız ve kusursuz bir șekilde genetik materyali elde etmek için güçlü bir teknik arayıșına girmișlerdir. Bu amaç doğrultusunda Polimeraz Zincir Reaksiyonunu geliștirerek bașarılı olmușlardır (5).

\section{PZR'nin Genel Mekanizması}

PZR, DNA kompleks havuzundan spesifik bir DNA parçasını çoğaltmaya olanak sağlayan basit ve neredeyse kusursuz, enzimatik bir ișlemdir. PZR ișlemini kavramsallaștıran Kary Mullis PZR yöntemini “DNA'nın yalnızca ilgilendiğiniz bir parçasını istediğiniz kadar almanıza olanak sağlıyor” șeklinde açıklamıștır. PZR yönteminde periferik kan, deri, saç, tükürük ve mikroorganizma olmak üzere farklı tipte hayvansal ve bitkisel kökenli materyal DNA kaynağı olarak kullanılmaktadır. PZR için gerekli olan DNA miktarının elde edilmesi ve yalnızca yeterli miktarda kopyanın analiz edilmesi geleneksel laboratuvar yöntemleri ile sağlanır. Bu nedenle PZR hassas bir yöntemdir (3).

PZR yöntemlerinde termal döngü cihazı kullanılmaktadır. Termal döngü belirli bir diziye 
sahip PZR örneğinin ısıtılması ve soğutulmasıdır. PZR'nin termal döngüsü; DNA erime sıcaklığı ve DNA replikasyon enzimleri için ısıtma ve soğutma reaksiyonlarının tekrar tekrar uygulanmasıyla ısıya dayanıklı DNA Polimeraz, primer dizi (tamamlayıcı hedef bölge) ve dNTP karışımı kullanılmasına dayanır. Böylelikle, milyonlarca kopya DNA'nın çoğaltılması gerçekleștirilmiş olur. Denatürasyon, bağlanma ve uzatma işlemleriyle hem orjinal DNA şablonuna ve hem de tamamlayıcı bölgeye bağlanabilen primer ile yeni iplikler sentezlenmesine devam edilir ve DNA yeni kopyalar üretmek için uzatılır. Sonuç olarak PZR primer dizileri içeren DNA parçaları üstel olarak artmış olur (6-8).

\section{PZR Çeşitleri}

PZR tekniğinin bulunmasından günümüze kadar gelişen teknolojiyle birlikte pek çok PZR tekniği ortaya çıkmıştır. Bunlardan en sık kullanılanlar Gerçek Zamanlı PZR, Kantitatif PZR, Ters Transkriptaz PZR, Nested PZR ve Multipleks PZR'dir.

Gerçek Zamanlı PZR tekniğinin kullanımı son derece yaygin olup, DNA ya da mRNA gibi makromoleküllerin çoğaltılmasına ve ürünlerin tek bir tüpte tespit edilmesine olanak sağlar (9). Bu metot sayesinde çok az miktardaki biyolojik bir örneğin hedef bölgesinin varlığına/yokluğuna veya miktarına hızlı, güvenilir ve hassas bir șekilde ulașılabilmektedir (10).

Gerçek Zamanlı PZR (qPZR)'nin normal PZR'den farkı, bașlangıç DNA miktarının hesaplanabilmesidir. Bu metot ile DNA amplifikasyonu, artan floresan ölçümleri ile ilişkilendirip kantitatif sonuçlar elde edilir (11).

Ters Transkriptaz PZR ise RNA moleküllerinden komplementer DNA (CDNA) sentezini, retrovirüslerden izole edilen Revers Transkriptaz enzimi ile gerçekleștirilmesidir. Hassas ve hızlı bir yöntemdir. CDNA sentezlendikten sonra DNA-RNA sarmalı ayrılır, ayrılan DNA dizisi kalıp olarak kullanılarak çift zincirli DNA dizisi çoğaltııır (12).
Nested PZR metodu PZR'nin spesifikliğini arttırmak için geliştirilmiş olup, birbirini takip eden iki polimeraz zincir reaksiyonu ile karakterizedir. ilk amplifikasyonda, hedef DNA dizisinin dış bölgesine özgü iki dıș primer kullanılır ve uzun bir bölgenin çoğaltılması gerçekleștirilir. İkinci amplifikasyonda ise ilk amplifikasyondan gelen bölgenin iç kısmına bağlanan iki iç primer kullanılarak kısa bölgenin de çoğaltılması gerçekleștirilir (11).

Multiplex PZR (mPZR) metodunda ise kalıp DNA üzerinde birden fazla bölge için çoklu primer çifti tasarımı gerçekleștirilir. Sonuç itibariyle aynı örnek üzerinde çoklu bölgenin çoğaltılmasına imkan sağlar. Net, hızlı ve güvenilir bir metottur (13).

\section{Dijital PZR}

Şimdiye kadar geliștirilmiș PZR türlerindeki zorluklar ve kullanım alanlarının daha da genișletilmek istenilmesi ile ileri teknoloji PZR geliștirilmesi araștırmacıların öncelikli hedefi haline gelmiștir.

Son yllarda dijital PZR olarak bilinen yeni versiyon PZR, yaygın olarak nükleik asit miktarının belirlenmesinde kullanılan bir yöntemdir. Örneklerin mikrolitrenin altında porsiyonlanıp nükleik asit ölçümlerinde kesinliğin, güvenilirliğin, doğruluğun ve tekrarlanabilir ölçümlerin arttırıldığı bir sistemdir. $\mathrm{Bu}$ yöntem analog qPZR'nin aksine, çoğaltma ișleminin nerede yapıldığına dair logaritmik sinyali, dıș kalibrasyona dayalı miktar tayinini, doğrusal ve dijital miktar tayininin sayı olarak pozitif ve negatif reaksiyonlarının sayısını, Poisson dağılımlarını dikkate alarak, hesaplamaya olanak sağlar (48).

qPZR ile kıyaslandığında sonuçlar daha düşük analitik hassasiyette olabilmesi gibi dPZR metodunda reaksiyon hacmine bağlı olarak bazı kısıtlamalar olmasına rağmen, düşük DNA konsantrasyonlarını ölçmeye ve tekrarlanabilir ölçümler yapmaya olanak sağlar. dPZR'nin bu avantajları göz önünde bulundurulduğunda, kendisine birçok kullanım alanı bulmuștur ve büyük potansiyale sahiptir. Örneğin; bitki patojenleri, genetiği değiștirilmiș organizma testleri, 
dirençli bakterilerin tespiti, viral teșhisler, nadir mutasyonların tespiti ve kopya sayısı varyasyonları alanlarında kullanılmaktadır (48).

Örneğin; qPZR tekniğindeki standartlar aracılığıyla analizlerin kalibrasyonunda teknik sınırlamalar mevcuttur. Bu tekrarlı iș akıșı araștırmacıya vakit kaybettirmektedir (14). Standart analog ölçümlerde aynı analiz belirteçlerini kullanacak bir yöntem geliștirmek amacıyla yola çıkan araștırmacılar, kısıtlı örneklerde bile çalıșan ve dijital formatta bilgi veren dPZR'yi geliștirmișlerdir (23).

Klasik genetikte, germ hattı mutasyonları sadece hastalığı anlamak için önemli kabul edilmiștir. Somatik mutasyonların gerçekleșmesi kanserin birincil nedenidir ve aynı zamanda yaşlanmada rol oynayabileceği yeni genetik prensipler olarak ortaya çıkmıștır. Bu keșifler hastalığın yönetilmesine fayda sağlarken aynı zamanda neoplazi patojezinin temel araștırmalarına da olanak sağlar. Bununla birlikte bu fırsatlar çok fazla miktardaki normal hücre arasından bir miktar mutant hücrenin tespitine bağlıdır (23).

DNA dizilemesi, germ-line mutasyonların saptanması için altın standart ama mutasyona uğramış aleller yaklaşık \%20 daha büyük olduğu zaman kullanıșlıdır. Mutantlara spesifik olan oligonükleotitler bazen küçük miktardaki hücrelerde mutasyonları tespit etmek için kullanılabilir fakat mutant ve vahşi tip (WT) șablonların ses sinyali oranı değișkendir. Mutantlara spesifik primerlerin kullanılması ve spesifik restriksiyon endonükleazlar ile PZR ürünlerinin parçalanması gibi yöntemler mutasyonların saptanması için çok hassas yöntemlerdir ama bu tekniklerle başlangıç popülasyonlarında mutant moleküllerin bölümlerini nicelendirmek zordur. Somatik mutasyonların saptanması için diğer yaklaşımlar gözden geçirilmiștir. Bu yöntemler ile ilgili genel sorun bağımsız bir șekilde herhangi bir mutasyonun varlığının teyit edilmesinin zor veya imkansız olmasıdır. Bu nedenle belirtilen güçlüklerin üstesinden gelmek için bazı yaklașımlar geliștirilmiștir. Elde edilen PZR ürünleri tamamen mutant ya da tamamen WT'dir. Böylece bu makalede anlatılan strateji ayrı ayrı şablon moleküllerin amplifikasyonunu içerir. PZR ürünlerinin homojenliği mevcut olan tekniklerin ayırt edilmesini kolaylaștırır. Bu gibi ayrı amplifikasyonlar pratik anlamda yararlıdır. Bununla birlikte çok sayıda basit ve güvenilir tespit elde edilebilir. Bu tür değerlendirmeler için kullanılan tekniklerde analizi yapılan popülasyonlarda mutant allel formlarının çıktı veren dijital okuması sağlanarak geliștirilmiștir. Bu uygulama teknolojileri için çeșitli öngörüler bulunmaktadır (23).

Dijital PZR, kendi gücünün bașka bir örneğini temsil etmektedir, son zamanlarda geliștirilen tespit teknolojileri ile birlikte genetik analizler için fırsatlar sağlamaktadır (23).

Nadir mutasyonların, kopya sayısı varyasyonlarındaki ufak değișikliklerin, gen ifadesi değișiklikleri arasındaki farklılıkların veya metilasyon durumunun değerlendirilmesinin tespitine izin veren yeni bir yöntem olarak dPZR teknolojisi geliștirilmiștir (15).

Tek bir molekülün sayımıyla nükleik asitlerin mutlak ölçümü sınırlayıcı dilüsyon (seyreltme) ve Poisson istatistiksel analizine olanak sağlaması 1992 yılında Sykes ve arkadașları tarafından rapor edilmiștir (16).

Dijital PZR, DNA kopya sayısının hassas ölçümü için PZR bazlı yeni bir tekniktir ve örnekleri az sayıda seyrelterek çok sayıda PZR reaksiyonu gerçekleștirmeye olanak sağlar (17). Bu teknikte, her biri ayrı ayrı PZR reaksiyonu geçiren çok sayıda küçük bölümler bulunmaktadır (18). Yöntem, birçok ayrı PZR reaksiyonunun sınırlı seyreltilmesi temeline dayanır (19). Aynı zamanda dPZR; șu an çok az miktardaki genetik materyalin dakikadaki miktarını tespit etme performansıyla birçok nicel yöntemleri geride bırakan güçlü ve uygun tek molekülü sayma stratejisidir (15).

Droplet dijital PZR (ddPZR) standart bir eğriye ihtiyaç duymadan nükleik asitlerin mutlak kantitatif ölçümüne olanak sağlar. Bu teknik 20.000 ve hatta 
çok daha küçük droplet adı verilen reaksiyon kapları içinde nükleik asitlerin porsiyonlanması temeline dayanır. Standart bir PZR reaksiyonu daha sonra her bir droplet hedefini çoğaltmak için kullanılabilir, böylelikle ayrı ayrı pozitif ve negatif șekilde hedef bağımlı floresan sinyali ölçülebilecektir. "1" olan sinyal pozitif, " 0 " olan sinyal negatif olmak üzere ikili kod tekniğin dijital kısmını temsil eder ve veriler Poisson dağılımına uygun olarak hesaplanabilmektedir. $\mathrm{Bu}$ da standart eğriye gerek kalmadan herhangi bir örnekten DNA kopya sayılarının doğrudan ve basit bir şekilde hesaplanmasına olanak sağlar (21).

Seyreltilmiş örnek tek tek PZR reaksiyonlarına dağıtılır ve orjinal örnek miktarı analiz bölümlerinin toplam sayısı açısından olumlu bir büyütme ile bölümlerin sayısına göre ölçülür. Bölümlerin içindeki moleküllerin dağılımı bağımsız ve rastgele bir işlemdir (22). Dijital PZR bir numunedeki nükleik asitlerin, kesin olarak miktarının saptanmasını sağlar. Dijital PZR uygulaması için pratik ve ölçeklendirilebilen teknolojilerin eksikliği bu güçlü tekniğin yaygın olarak benimsenmesini engelliyordu. Burada yüksek verimli damlacık dijital PZR sistemi 96 kuyulu bir plaka ile geleneksel TaqMan probları kullanılarak 2 milyon PZR reaksiyonu işlenmesini sağlar (20) (Şekil 1). Ayrıca örneğin uygun bir șekilde seyreltilmesi genellikle reaksiyon bölümü bașına sadece bir hedef molekülün incelenmesini garanti eder. Daha yüksek konsantrasyonda kalıp kullanılırken, moleküllerin gerçek sayısı gözden kaçabilir çünkü bazı bölümler birden fazla kalıp molekül içerir. Kullanılan Poisson istatistiği bu bozulmayı bir dereceye kadar önleyebilir (23). Floresan kimyası teknolojisi özgül bir PZR ürünün varlığını veya yokluğunu algılamak üzere qPZR'da da olduğu gibi dPZR'da da kullanılmaktadır. Sonuçta verilerin yorumlanması karmaşık biyoinformatik analizlere sıkı sıkıya bağlı değildir. Bazı uygulamalarda, ardışık olasılık oran testi allel dağılımı normalden farklı olduğu için kanıtların gücünü ölçmekte kullanılabilir (24).

\section{Örneğin Șekil 2'de;}

(A) Master mix içeren $20 \mu \mathrm{L}$ numune, primerler, TaqMan probları ve hedef DNA, sekiz kanallı damlacık jeneratör kartuşunun orta kuyularına yüklenir. Emülsiyon stabilize edici yüzey aktif madde içeren damlacık olușturma yağı $(8 \times 60 \mu \mathrm{L})$ daha sonra damla üreteci kartuşunun solundaki kuyunun içine yüklenir. Bir vakum bir basınç farkı olușturmak için çıkıș kuyusuna (sağdaki kuyu) otomatik olarak uygulanır, bu arada mikroakışkan döngü geometrisi sulu örneğin içinde istikrarlı hale dönüşür. Tek dağılımlı olarak su içindeki yağ emülsiyon damlacıkları ve yağ fazındaki yoğunluk farklııkları nedeniyle yoğunlașarak kartuşun damlacık toplama kuyusunda toplanır. Her bir kuyudaki damlacıklar daha sonra 96 oyuklu, folyo ile kapatılmıs plakaya aktarılır ve son olarak termal döngüye girer (25).
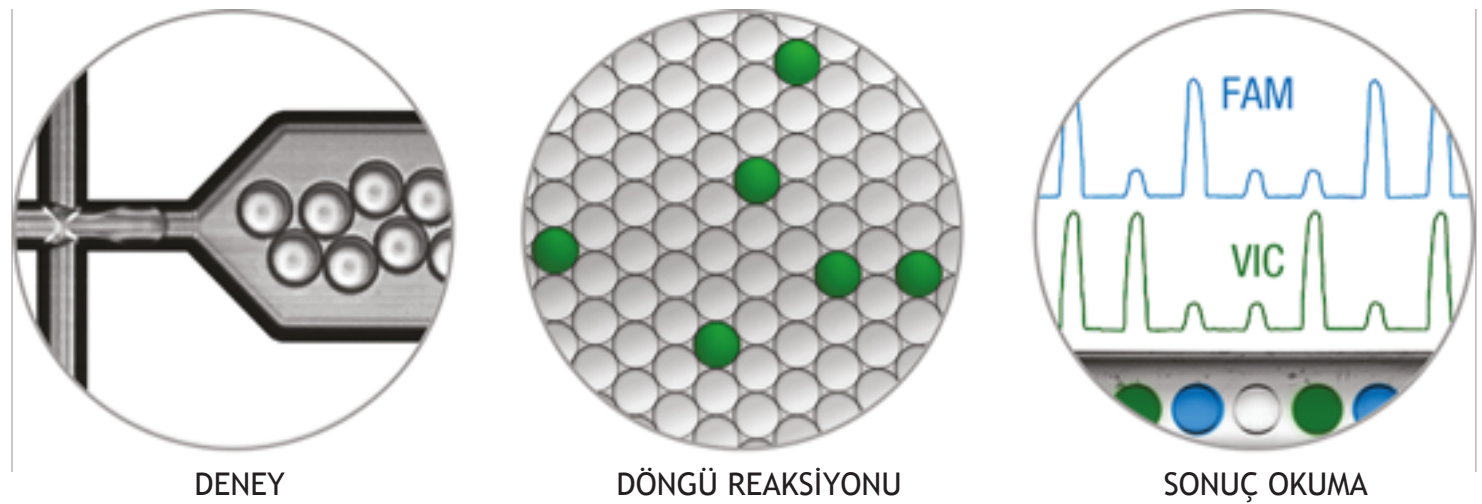

Şekil 1. Dijital PZR'a genel bakıș (20) 
(B) Amplikasyon sonrasında plaka damla okuyucuya yüklenir ve burada otomatik olarak damlacıklar mikroakışkan singulatör kullanılarak aspire edilir. Örnekler 100 kHz hızında tek sıra halinde FAM/VIC iki renkli floresan dedektöründen geçirilir.

(C) Damlacıklar için floresan genliklerindeki farklılıklar amplifikasyon varsa veya hiç oluşmadığı durumlarda tipik Fam/Vic dubleks çalıșmaları için tüm damlacık populasyonunu dört ayrı küme halinde böler. Bu dört popülasyonlar hiçbir hedefin bulunmadığı ( $\mathrm{F}-/ \mathrm{V}-$ ), hedeflerin birinin $(\mathrm{F}-\mathrm{V}+/ \mathrm{F}$ $+\mathrm{V}-)$ veya hedeflerin her ikisini de $(\mathrm{F}+/ \mathrm{V}+)$ içeren damlacıklar vardır. Damlacıkları sınıflandıran dijital yöntemde her algılama kanalı için bir floresan eșiği ayarlanmıștır ve damlacık bașına düșen ortalama kopya sayısının hesaplanması pozitif damlacıkların fraksiyonu ve Poisson modelleme ile bulunabilir (25) (Şekil 2).

dPZR'nin yukarıda belirtilen özellikleri diğer yöntemlerin tespit yeteneklerinden farklıdır, bu da çeşitli araștırma uygulamaları için dPZR yaklaşımını eșsiz kılar (15). Son zamanlarda dPZR'nin DNA mutlak ölçümü kapasitesi, yeni nesil DNA dizileme kütüphanesinin hazırlanmasında kullanılmıștır (26).

Dijital PZR'nin diğer PZR teknolojilerine göre üstünlükleri

Dijital PZR, qPZR'a kıyasla daha yüksek hassasiyet gösteren PZR bazlı mutlak ölçüm tekniğidir. Bugüne kadar yapılan kanser ve viral enfeksiyonlar üzerindeki çeșitli çalıșmalar dPZR'nin qPZR'a göre duyarlılığının ve hassasiyetinin daha yüksek olduğunu göstermiștir (17). Bu avantajın asıl nedeni, reaksiyonların tek tek bölümlendirilebilmesidir (20). Geleneksel qPZR ile karșılaștırırsak ddPZR daha düșük saptama limitlerine ve daha büyük dinamik aralığa sahiptir (21).

Dijital PZR teknik olarak Gerçek Zamanlı PZR'den çok daha basittir ve eșik (threshold) verilerini yorumlayabilmek için standart dilüsyon eğrilerine gerek duyulmamaktadır (19). Böylelikle qPZR ile tespit edilemeyen biyolojik ve translasyonel potansiyele sahip çok düşük düzeyde açıklanan genlerin varlığı ddPZR ile tespit edilebilmektedir. Buna ek olarak, dPZR'nin bir üstünlüğü de mutlak ölçüm sağlamasıdır. qPZR kullanılarak tespit edilemeyen düșük veya limitli
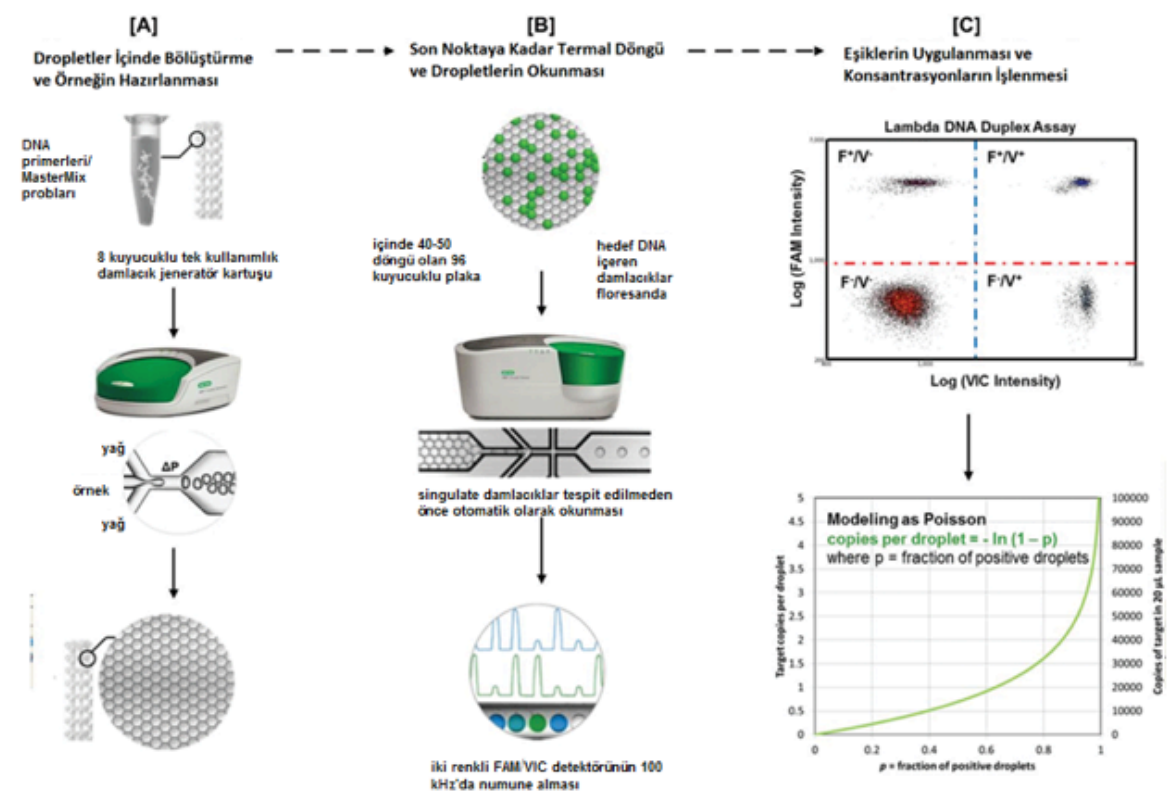

Şekil 2. ddPZR'nin genel çalıșma prensibi (25) 
miktardaki hedefleri tespit etmek için kullanılması çalıșmalara avantaj sağlar (27).

dPZR'nin daha kesin sonuç vermesindeki en önemli özellik metot sağlamlığından (robustness) ileri gelmektedir. qRT-PZR daha yüksek bir dinamik aralığa sahip olmasına rağmen dijital PZR örnekler arasındaki en ufak değişiklikleri bile saptamaya olanak sağlar. qRT-PZR'nin aksine dijital PZR, azaltılmış PZR verimliliği karşısında daha dirençlidir. QRT-PZR ile

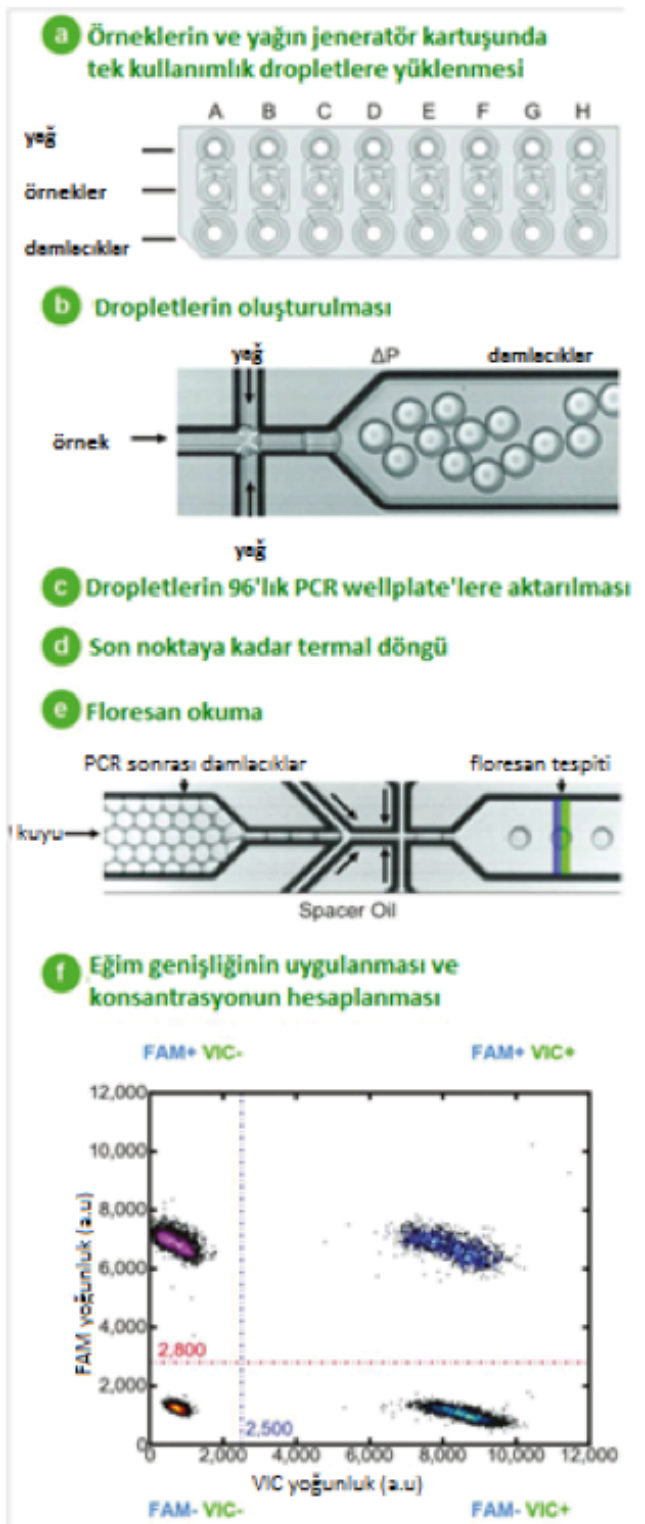

Şekil 3. dDroplet dijital PZR' in çalıșma prensibi (20) karșılaștırıldığında dezavantaj olarak daha düșük bir dinamik aralığı vardır (18).

\section{dPZR Avantaj ve Dezavantajları}

Dijital PZR'da daha düşük maliyetlerde yüksek verimlilik mümkündür (17). Yeterli seyreltmeler ile, birçok reaksiyon standart bir eğriye ihtiyaç duymadan Poisson istatistikleri kullanılarak șablon bir DNA içermeden ölçüm gerçekleștirilir (19). Bu yeni metot analizin daha uygulanabilir ve tekrarlanabilir olmasına olanak sağlar (28).

Droplet dijital PZR (ddPZR), teorik olarak tek bir hedef molekülün saptanabilmesine olanak sağladığından dolayı hassasiyeti yüksek olan bir metottur (18). ddPZR son derece düşük frekanslı durumlarda bile efektif çalıșır (29).

PZR verimliliğin hesaplanması için seyreltme eğrilerine ve mutlak ölçüm için DNA standartlarına gerek yoktur (18). dPZR hedef RNA miktarı çok düşük olsa bile gen ekspresyonunun saptanmasina olanak sağlar (27).

Harici standartların kullanılması qPZR'da analitik performans ölçmede merkez noktadır. Harici kalibratörlere dPZR'da gerek duyulmaması ve enzim inhibisyonuna yol açacak maddelere karșı tolerans sahibi olması, nükleik asit kantifikasyonunda kullanılmasının temel sebebidir $(26,30)$. Her iki teknoloji de nükleik asitlerinin keșfinde aynı floresan kimyasını kullansa bile; dPZR dinamik diziyi eș zamanlı etkileyerek aynı anda kalıbın çoğaltılması için partikül sayımına izin vererek daha kesin bir ölçüm sağlayabilmektedir. dPZR teknolojisindeki son gelișmeler reaksiyon bölümlerinin binlerden milyonlara kadar olmasıyla ölçeklenebilir bir ortam sağlar (20). Sonuç olarak dPZR, qPZR'a göre daha üstün hassasiyet göstermekte olup, duyarlılık ve tekrarlanabilirlik açısından da nükleik asit ölçüm imkanı sunmaktadır. Lakin düșük maliyetli olması açısından Kantitatif Gerçek Zamanlı PZR günümüzde hala en çok kullanılan nükleik asit ölçüm yöntemidir (15). Teknik ön amplifikasyon adımına gerek kalmadan 
nükleik asitlerin izlerini tespit etmede son derece güçlüdür böylece tahlile özgü önyargılı bir giriş önlenmiş olur (31).

Analitik kesinliğine karșılık gelen katsayı “coefficient" varyasyon değeri, qPZR'a göre dPZR için önemli ölçüde daha düşük olduğu gösterilmiștir (15). Dahası, kalıp bölmeleri azaltılarak arka plandaki DNA ve kirleticilerin seviyeleri düşürülür, pozitif reaksiyon bölümlerinin sinyal sesi arttırılmış ve böylece algılama hassasiyeti arttırılmıș olmaktadır (32).

\section{Kullanım Alanları}

dPZR tekniğinin kullanım alanlarından bahsedecek olursak; heterojen tümörlerde ya da genetik kökenli hastalıklarda nadir allel tespitlerinde (33), periferal vücut sıvılarını kullanarak solid tümörlerin likit biyopsisinde (34), invaziv olmayan prenatal tanida (20), viral yük tespitinde (35), gen ekspresyonunda, heterojen örneklerde kopya sayısı varyasyonlarında (36) (Şekil 5), kısıtlı miktardaki örneklerin analizinde, örneğin FFPE örnekleri ve tek hücre gen ekspresyonu gibi, dizileme öncesi DNA kalite testlerinde (26, 37) (Șekil 4), gıda alanında Genetiği Değiștirilmiş Organizma (GDO) (38) tespitinde kullanılmaktadır.

Örneğin Şekil 4'te görüldüğü üzere; DNA, daha önceden arșivlenmiș bir kanser numunesinden elde edilir. Formalin ile parafin bloğa fikse edilen mide adenokarinoma örneği beraberindeki lekeli bölüm ile gösterilmiștir. DNA izolasyonundan sonra damlacık PZR belirli bir gruba ait PZR primerleri ve floresan probu ile yapılmaktadır. PZR sonrası emilsiyon damlacıkları iki renkli bir detektöre açılan kılcalın içine doğru tek tek akar; hedef ve referans genler için pozitif damlacıklar 6-FAM ve VIC gibi farklı boyalarla kopya sayısı kantitatif olarak sayılabilir. Bir boya kontrol bölümüne özgüldür ve diğer bölümleri ölçer. Mevcut örnek, eğer tümör hücrelerinin sadece küçük bir kısmını içeriyorsa bile anormal genomik amplifikasyonları algılamak için ddPZR kullanarak FFPE tümör örneklerinde genomik amplifikasyonları ölçmek için güçlü bir çözüm geliștirilmiștir. ddPZR metodunda genomik DNA'dan nanogram miktarda olması yeterlidir, böylece nadir numuneleri bile çalışılması kolaylașmıştır. Hindson ve arkadaşları tarafından açıklandığı gibi ddPZR metodu belirli genomik etkinliklerin son derece hassas ve spesifik olarak saptanması için örneğin emülsifiye edilmesini içerir (44).

Verimli çalıșma platformları içinde dPZR'yi güçlü potansiyele dönüştürmek için, tek bir molekül büyütmesi süreci son derece istikrarlı bir ortamda gerçekleșmelidir. Platformun seçimi özellikle kesinlik derecesi, sonuç, sistem ve tahlillerdeki maliyete bağlıdır (15).

İlk nesil dPZR platformaları mikroakıșkan kanallar içeren çiplere dayanmaktadır (39). Hedef molekül gerçek zamanlı olarak izlenebilir böylece yanlıs pozitif reaksiyonlar her bir reaksiyonunun büyütme (amflikasyon) eğrisinden çıkarılabilir. Yüksek hassasiyet ve kesinlik için dijital platformların daha

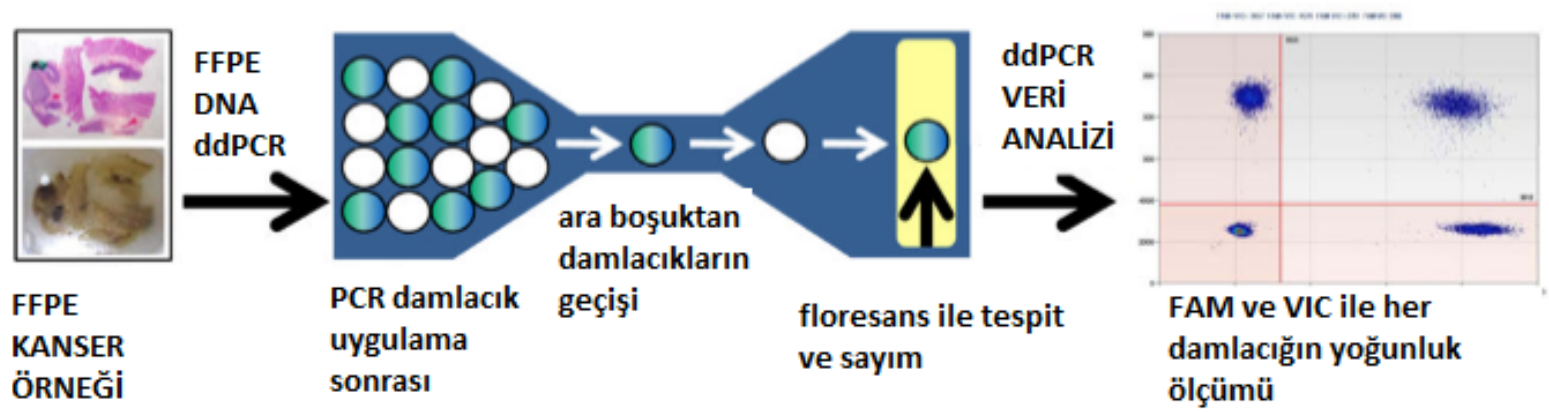

Şekil 4. Formalinde sabitlenmiș ve parafine yerleștirilmiș (FFPE) kanser doku örneklerinin amplifikasyon analizinde droplet dijital PZR'nin genel çalıșma prensibi (44) 
çok sayıda numaralandırılmasına ihtiyaç vardır. Bu nedenle, șirketler her dPZR reaksiyonunu yağda sulu damlacıkların içinde PZR okuma bitiș noktası ile birleștiren sistemlerini bașlatmışlardır. Bu platformlar Gerçek Zamanlı PZR ölçümü gerçekleștiremiyor olmalarına rağmen çok büyük sayıdaki reaksiyon bölümlerinin birbirine benzer ebattaki dinamik değerleri çarpıcı bir artışa yol açmıştır (25). Sysmex Inostics tarafından sağlanan beaming dijital PZR teknolojisi (boncuk, emülsiyon, amplifikasyon ve manyetik) klonal manyetik parçacıkların varlığında nükleik asitleri çoğaltmaya ve sitometri akıșı kullanılarak da miktarı değerlendirmeye olanak sağlar (40). Bu dPZR stratejisi, özellikle kanser araștırmalarında geniş kullanım alanı bulmuștur (15).

Örneğin Şekil 3'te görüldüğü üzere;

a) Örnekler ve damlacık olușturma yağı sekiz kanallı damlacık jeneratör kartuşu içine yüklenir.

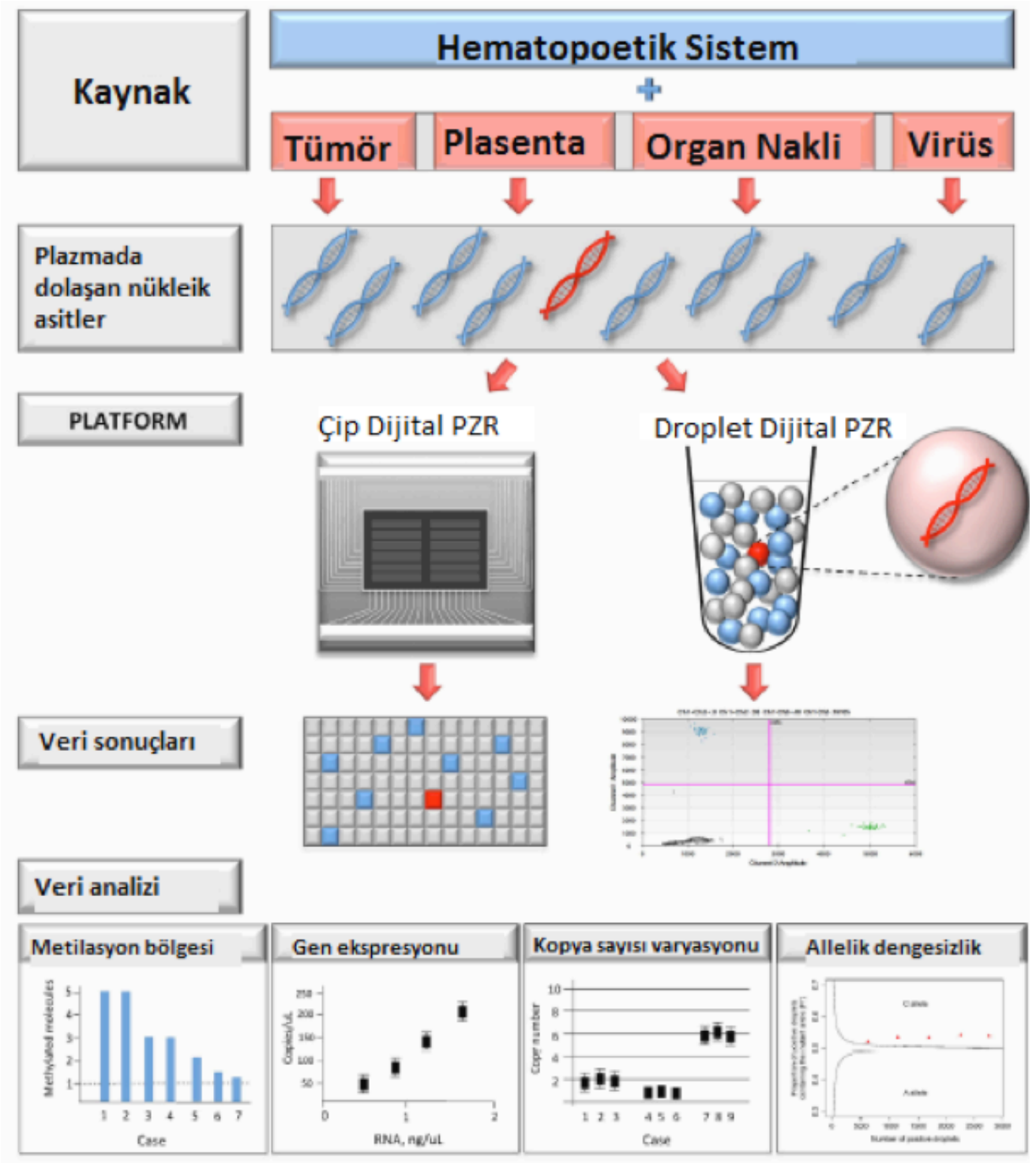

Şekil 5. Dolașan nükleik asit araștırmasında çip veya droplet dijital PZR teknolojisinin șematik gösterimi (15) 
b) 1 nl’lik damlacıklar halinde örneğin ve yağın akıșıyla vakum ișlemi gerçekleșir. İki dakikadan az bir süre içerisinde, sekiz örnek 20.000 damlacıklı sekiz sete dönüșür.

c) Satbilize olan damlacıklar 96' ık wellplate'lere aktarılır.

d) Droplet PZR'nin çoğaltma basamağından son așamaya kadar (3.545 döngü) termal döngü ișlemleri gerçekleșir.

e) Her bir kuyucuktan çekilen damlacıklar plaka okuyucuya yüklenir, saniyede yaklașık 1.000 adet geçecek șekilde iki renkli dedektörden geçirilir.

f) Damlacıklar floresan genliklerine göre pozitif ve negatif olarak atanır. Her kanal içerisindeki pozitif ve negatif damlacıklar, \%95 Poisson güven aralığında olmak üzere, hedef ve referans DNA dizilerinin konsantrasyonun hesaplanmasında kullanılır (20) (Şekil 3).

dPZR'nin klinikte RNA biyobelirteçlerinin saptanmasında ve miktarının belirlenmesinde kullanıșlı olabileceği belirtilmiștir (27). dPZR'nin analitik gücü bir kopya bașına 100.000 yabanıl tip dizinin altında tek bir nükleotid varyantının algılanmasını sağlar (41).

Meme kanseri hücre hattı ile ilgili araștırmalar, HER2 gen kopya sayısı varyasyonunda ince kat farklılıklarının saptanmasında qPZR'a kıyasla dPZR'nin daha üstün hassasiyet ve duyarlılık gösterdiği rapor edilmiștir (36). Dijital PZR kolorektal kanser ve meme kanseri olan hastalarının plazmasındaki belirli bir lokusun metilasyon durumunun değerlendirilmesi için kullanılmıștır $(42,43)$.

1999 yılında kolorektal kanser ile ilișkili ras onkogen mutasyon miktarının belirlenmesi için Vogelstein ve Kinzler öncü bir çalıșma yaparak dPZR'nin klinik çalıșmara yardımcı bir program olabileceğini vurgulamıștır (23). Ancak zahmetli olușu klinik ortamda rutin kullanımını engellemiștir. Böylece pratik gelișimine odaklanılması yönünde çalıșmalar yapılması gerektiği belirtilmiștir. Daha sonra mevcut geliștirilen platformların pratikliği kolaylaștırılmıș ve birçok klinik alanda kullanımı sağlamıștır (20).

Viroloji ve bakteriyoloji alanında, Cytomegalovirus (CMV), Hepatit B virüs, HIV-1 virüs, metisilin-dirençli Staphylococcus aureus tespitinde ve viral yükün ortaya konmasında dPZR kullanılmıștır (49, 50-52). HIV-1 için yapılabilen düşük düzeydeki viral yük tespiti retroviral tedaviye faydalı olabileceğine ișaret etmektedir (53-55).

Mikroakıșkan çipler kullanılarak mikrodropletler sayesinde binlerce ya da milyonlarca reaksiyon dijital PZR ile ayrı ayrı bir örnek halinde incelenir. ddPZR örnekleri nanolitreden pikolitreye kadar minimalize edilmiș hacimlerde çalıșmaya olanak sağlamıștır. Reaksiyon PZR'nin son noktasına ulaștığında; damlalar ilgili hedef dizinin kopyalarını içermeyebilir ya da bazı kopyalarını içerir (27). ddPZR spesifik virüslerin düșük kopyalarının saptanmasında kullanıșlı olabilir (21).

ddPZR yüksek miktardaki örneklerin ölçümüne de uygulanabilir. ddPZR yaklaşık 45 dakika numunenin ișlenmesine ve sonrasında numune sayısına bağlı droplet okuma vakti olarak 1-2 saat daha ek süreye ihtiyaç duyar (21).

Kantitatif Dijital PZR Deneylerinin Yayınlanabilmesi İçin Gerekli Olan Minimum Bilgi (dMIQE) Kuralları

Dijital PZR için ilk ticari platform 2006 yılından beri piyasada olmasına rağmen, zaten iyi kurulmuş bir qPZR ile karşılaștırıldığında klinik ortamda tam potansiyele sadece bașlangıçta sahip olduğu gösterilmiștir. Klinik uygulama içinde dPZR uygulanması yolundaki ilk adım farklı laboratuvarlar arasında tekrarlanabilirliği geliștirmek için deneysel ayrıntıları bildiren bir çerçeve sağlayan dMIQE (Minimum Information for Publication of Quantitative Dijital PZR Experiments) kuralları yayınlayarak alınmıștır (45). MIQE kurallarını içeren kontrol listesi, qPZR analizlerinin geliștirilmesi, verilerin tekrarlanabilmesi ve karșılaștırılabilmesi amacıyla 
2009 yılında yayımlanmıștır. Tüm öğeler temel olanlar (E-Esansiyel) ya da isteğe bağlı olanlar (İ-isteğe bağlı) şeklinde kategorize edilmiştir (45).

\section{Sonuç}

Dijital PZR yeni uygulamalar ve araștırmalar için gelișmekte olan yeni bir PZR tekniği olarak karșımıza çıkmıştır. Güvenilirlik ve tekrarlanabilirlik düzeyi oldukça yüksek bir yöntemdir. Çok düşük hacimlerde ve tek molekül konsantrasyonunda çalșslabildiğinden dolayı, yöntem yüksek hassasiyet gerektirmektedir. Deney tasarımı yapılmadan önce tek bir hedef olduğundan emin olunmalıdır. Birden çok hedef olduğu takdirde ise, her hedef farklı bir kuyucukta ișlem görür (46).

Nadir allel tespiti durumunda, yanlıș pozitiflerin oranı oldukça önemlidir. Çok oldukları taktirde gerçek pozitiflerin sayısını maskeleyebilirler. Kalıbın başlangıç konsantrasyonu da oldukça önemlidir, numunenin uygun seyreltilmesi bu konsantrasyona göre belirlenir. Daha önce de bahsettiğimiz gibi dijital PZR teknolojisinde, standart eğriye gerek duyulmadan DNA parçaları arasında hassas moleküler ölçümler gerçekleștirilebilir, yüksek özgüllük hassasiyeti görülür ve yüksek tekrarlanabilirlik mümkündür. $d P Z R$ 'nin en büyük gücü kalibratör referansa ihtiyaç duymadan, kantitatif ölçümler ile hassas bir șekilde doğrudan sayım yapabilmesidir (46).

Araștırmacılar dPZR'nin potansiyeli hakkında istekli olmalarına rağmen, deney tasarımında dikkatli olunması hususunda uyarıda bulunmaktadır. Teknolojinin olgunlaşıp olgunlașmayacağı, maliyetin de azalıp azalmayacağı şu an birçok araştırmacı için merak konusudur. Şu an az miktarda uygulama alanı olsa da yarın çok daha fazla kullanım sahasının olması beklenmektedir (47). Gelișmiș dizileme yöntemi ile dPZR'nin diğer PZR yöntemlerinin yerini alabileceğini söyleyebiliriz, fakat bunun ne zaman gerçekleșeceğini tahmin etmek zordur (31).

Bu tartıșmalar üzerine, bu derlemede dPZR'nin bilinirliğini ülkemiz bilim camiasında arttırmak, bu tekniğin gıda ve sağlık alanlarında nadir allel tespiti ve düşük düzey genetik analizlerde uygulanmasının teșvik edilmesi amaçlanmıştır. İlgili teknolojinin kabul edilebilirliğini arttırmak ancak bu tekniğin kullanımının yaygınlaștırılması ile mümkündür. Laboratuvar çalışmalarında kullanımda olan moleküler teknikler tek bașına bütün sorularımıza cevap verememektedir. Metotlar birbirinin tamamlayıcıları durumundadir. Dolayısı ile dPZR, kullanım alanlarında hassasiyeti yakalamak isteyenlere daha doğrulayıcı bir yaklașım sağlayabilecektir.

Tablo 1. Tüm kullanıcılar için Kantitatif Dijital PZR deneylerinin yayınlanabilmesi için gerekli olan minimum bilgi (dMIQE) kurallan listesi (45)

\begin{tabular}{lc}
\hline Kontrol edilecek öge & $\begin{array}{c}\text { Önemlilik } \\
\text { derecesi }\end{array}$ \\
\hline \multicolumn{1}{c}{ Deneysel Tasarım } \\
\hline Deney ve kontrol gruplarının tanımlanması & E \\
\hline Her grup içindeki numaralar & E \\
\hline $\begin{array}{l}\text { Analizler merkezi labda mı yoksa araştırmacının } \\
\text { kendi labında mı gerçekleștirilecek? }\end{array}$ & i \\
\hline Güç analizi & i \\
Örnek tanımı & $\mathrm{E}$ \\
\hline
\end{tabular}

\begin{tabular}{lc}
\hline \multicolumn{1}{c}{ Kontrol edilecek öge } & $\begin{array}{c}\text { Önemlilik } \\
\text { derecesi }\end{array}$ \\
\hline \multicolumn{1}{c}{ Deneysel Tasarım } & \\
\hline Mikroğin hacmi veya kütlesi & E \\
İşleniş prosedürü & E \\
$\begin{array}{l}\text { Eğer dondurulma varsa-nasıl ve hangi hızda? } \\
\text { Fikse edilecekse, ne ile ve hangi hızda? }\end{array}$ & E \\
Örneğin saklanma koșulları ve süresi & E \\
\hline
\end{tabular}


Tablo 1. Devam

\begin{tabular}{|c|c|}
\hline Kontrol edilecek öge & $\begin{array}{r}\text { Önemlilik } \\
\text { derecesi }\end{array}$ \\
\hline \multicolumn{2}{|l|}{ Nükleik asit ekstraksiyonu } \\
\hline Miktar tayini-Gereçler/Yöntem & $\mathrm{E}$ \\
\hline $\begin{array}{l}\text { Saklama koșulları: sıcaklık, } \\
\text { konsantrasyon, süre, tampon çözelti }\end{array}$ & $\mathrm{E}$ \\
\hline DNA veya RNA miktar tayini & $\mathrm{E}$ \\
\hline Kalite/bütünlük, cihaz/yöntem & $\mathrm{E}$ \\
\hline Kalıbın yapısal bilgisi & E \\
\hline $\begin{array}{l}\text { Kalıp modifikasyonu (sindirim, } \\
\text { sonikasyon, preampflifikasyon, vs) }\end{array}$ & $\mathrm{E}$ \\
\hline $\begin{array}{l}\text { Kalıp iyileștirme (ilk ısıtma ya da } \\
\text { kimyasal denatürasyon) }\end{array}$ & $\mathrm{E}$ \\
\hline Seyreltmenin engellenmesi & E \\
\hline $\begin{array}{l}\text { RNA örneğinde DNA kontaminasyonun } \\
\text { değerlendirilmesi }\end{array}$ & $\mathrm{E}$ \\
\hline DNAaz ile muamelenin detayları & E \\
\hline $\begin{array}{l}\text { Kullanılan reaktiflerin üreticisi ve } \\
\text { katalog numaraları }\end{array}$ & i \\
\hline $\begin{array}{l}\text { Nükleik asitlerin saklama koșulları: sıcaklık, } \\
\text { konsantrasyon, süre, tampon çözelti }\end{array}$ & $\mathrm{E}$ \\
\hline \multicolumn{2}{|l|}{ RT (Eğer gerekliyse) } \\
\hline cDNA olușturma yöntemi ve konsantrasyonu & E \\
\hline Bir ya da iki-basamak protokolü & E \\
\hline Reaksiyon bașına kullanılan RNA miktarı & $\mathrm{E}$ \\
\hline $\begin{array}{l}\text { Reaksiyon bileșenlerinin ve koșullarının } \\
\text { ayrıntıları }\end{array}$ & $\mathrm{E}$ \\
\hline RT verimliliği & i \\
\hline $\begin{array}{l}\text { RT ile birlikte ve RT olmadan ölçülen } \\
\text { tahmini kopyalar }\end{array}$ & i \\
\hline Reaktiflerin üreticisi ve katalog numaraları & i \\
\hline $\begin{array}{l}\text { Reaksiyon hacmi ( } 2 \text { basamaklı RT } \\
\text { reaksiyonu için) }\end{array}$ & i \\
\hline $\begin{array}{l}\text { CDNA'nın saklanma koșulları: sıcaklık, } \\
\text { konsantrasyon, süre ve tampon çözelti }\end{array}$ & $\mathrm{i}$ \\
\hline
\end{tabular}

Kontrol edilecek öge

Önemlilik

derecesi

dPZR hedef bilgisi

Sekansın katılım numarası

Amplikon konumu

Amplikon uzunluğu

E

BLAST vs gibi veritabanlarındaki

özgüllük ekranı

$E$

Pseudogenler, retropseudogenler veya diğer homologları

Sekans hizalama

Amplikonun ikinci yapı analizi ve GC içeriği

Ekzon veya intron tarafından olușturulan her primerin konumu (varsa)

Nerede uygundur, hangi ek varyantlar hedeflenmiștir?

dPZR Oligonükleotitleri

Primer dizileri ve/veya amplikon içerik dizisi

RTPrimerDB (real-time PZR primer ve prob veritabanı

Prob dizileri

Konum ve kimlik değișimleri

$E$

Oligonükleotitlerin üreticisi

Pürifikasyon yöntemi

i

\begin{tabular}{|c|c|}
\hline \multicolumn{2}{|l|}{ dPZR Protokolü } \\
\hline Reaksiyon koșullarının tamamlanması & $E$ \\
\hline $\begin{array}{l}\text { Reaksiyon hacmi ve RNA/cDNA/DNA } \\
\text { miktarı }\end{array}$ & $\mathrm{E}$ \\
\hline $\begin{array}{l}\text { Primer, (Prob), Mg2+ ve dNTP } \\
\text { konsantrasyonlar1 }\end{array}$ & $\mathrm{E}$ \\
\hline Polimeraz kimliği ve konsantrasyonu & $\mathrm{E}$ \\
\hline Tampon/Kit katalog numaralan ve üreticileri & $\mathrm{E}$ \\
\hline Tampon çözeltinin kimyasal içeriği & $\mathrm{i}$ \\
\hline İlaveler (SYBR gren I, DMSO, vs) & $\mathrm{E}$ \\
\hline
\end{tabular}


Tablo 1. Devam

\begin{tabular}{|c|c|}
\hline Kontrol edilecek öge & $\begin{array}{l}\text { Önemlilik } \\
\text { derecesi }\end{array}$ \\
\hline \multicolumn{2}{|l|}{ dPZR Protokoliu } \\
\hline Plate/Tüp katalog numaraları ve üreticileri & $\mathrm{i}$ \\
\hline Tam termodöngüleme parametreleri & $\mathrm{E}$ \\
\hline Reaksiyon kurulumu & i \\
\hline $\begin{array}{l}\text { Gravimetrik ya da hacimsel seyreltmeler } \\
\text { (manuel/robotik) }\end{array}$ & $\mathrm{i}$ \\
\hline Hazırlanan total PZR reaksiyon hacmi & $\mathrm{i}$ \\
\hline Bölüștürme sayısı & $\mathrm{E}$ \\
\hline Bireysel bölüștürme hacmi & $\mathrm{E}$ \\
\hline Ölçülen bölüștürme hacimleri & $\mathrm{E}$ \\
\hline Bölüștürme hacmi değișiklikleri/SD & $\mathrm{i}$ \\
\hline $\begin{array}{l}\text { Kontrollerin kapsamlı ayrıntıları ve uygun } \\
\text { kullanımı }\end{array}$ & $\mathrm{E}$ \\
\hline dPZR gereçlerinin üreticisi & $\mathrm{E}$ \\
\hline \multicolumn{2}{|l|}{ dPZR test sonucu kontrolü } \\
\hline Deney için optimizasyon verileri & i \\
\hline $\begin{array}{l}\text { Özgünlük ( nadir mutasyonlar, patojen } \\
\text { dizileri vs ölçülürken) }\end{array}$ & $\mathrm{E}$ \\
\hline Kalibrasyon kontrolünün saptama limiti & i \\
\hline
\end{tabular}

\begin{tabular}{|c|c|}
\hline Kontrol edilecek öge & $\begin{array}{l}\text { Önemlilik } \\
\text { derecesi }\end{array}$ \\
\hline \multicolumn{2}{|l|}{ Veri analizi } \\
\hline Bölüm bașına ortalam kopya (veya eșdeğeri) & $\mathrm{E}$ \\
\hline dPZR analiz programı (kaynağı, versiyonu) & $E$ \\
\hline Uyumsuz tanımlama ve düzen & $E$ \\
\hline Kalıp olmayan kontrollerin sonuçları & $\mathrm{E}$ \\
\hline $\begin{array}{l}\text { Ek veri olarak pozitiflerin ve negatif test } \\
\text { sonuçlarının örnekleri }\end{array}$ & $\mathrm{E}$ \\
\hline $\begin{array}{l}\text { Referans genlerin sayısının ve seçiminin } \\
\text { gerekçesi, uygunluğu }\end{array}$ & $\mathrm{E}$ \\
\hline Yöntemin normalizasyonu ve tanımı & $\mathrm{E}$ \\
\hline Biyolojik kopyaların uyumu ve sayısı & i \\
\hline $\begin{array}{l}\text { Tekniksel kopyaların basamağı (RT veya } \\
\text { dPZR) ve sayısı }\end{array}$ & $\mathrm{E}$ \\
\hline Tekrarlanabilirlik & $E$ \\
\hline Çoğaltılabilirlik & i \\
\hline Deneysel varyans & $\mathrm{E}$ \\
\hline Analiz için kullanılan istatistiksel yöntemler & $\mathrm{E}$ \\
\hline $\begin{array}{l}\text { RDML kullanılarak verileri gönderme } \\
\text { (Real-time PZR Data Markup Language) }\end{array}$ & i \\
\hline
\end{tabular}

Tüm öğeler temel olanlar (E-Esansiyel) ya da isteğe bağlı olanlar (I-isteğe bağlı) olarak kategorize edilmiștir.

\section{ÇIKAR ÇATIŞMASI}

Yazarlar herhangi bir çıkar çatıșması bildirmemektedir. 


\section{KAYNAKLAR}

1. Mullis KB. The unusual origin of the polymerase chain reaction. Sci Am, 1990; 262: 56-61, 64-5.

2. Bottero MT, Civera T, Nucera D, Rosati S, Sacchi $\mathrm{P}$, Turi RM. A multiplex polymerase chain reaction for the identification of cows', goats', and sheeps' milk in dairy products. Int Dairy J, 2003; 13: 27782.

3. Garibyan L, Avashia N. Polymerase Chain Reaction. J Investig Dermatol, 2013; 133 (3): e6.

4. Erlich HA, Gelfand D, Sninsky JJ. Recent Advances in the Polymerase Chain Reaction. Science, 1991; 252: 1643-51.

5. Gibbs RA, DNA Amplification by the Polymerase Chain Reaction. Analytical Chemistry Anal Chem, 1990; 62 (13): 1202-14.

6. Arnheim N, Erlich H. Polymerase Chain Reaction Strategy. Annu Rev Biochem, 1992; 61: 131-56.

7. Sharkey DJ, Scalice ER, Christy KG, Atwood SM, Daiss JL. Antibodies as thermolabile switches: High temperature triggering fort he polymerase chain reaction. Biotechnol, 1994; 12: 506-509.

8. Elizabeth G. How widespread is adult neurogenesis in mammals? Nat Rev Neurosci, 2007; 8: 481-8.

9. Klein D. Quantification using real-time PCR tecnology: Applications and limitations. Trends Mol Med, 2002; 8: 257-60.

10. Bustin SA, Mueller R. Real-time reverse transcription PCR (qRT-PCR) and potential use in clinical diagnosis. Clin Science, 2005; 109: 365-79.

11. Karataș M. Moleküler Biyoloji. Nobel Akademik Yayıncilık. 2012; 288-90.

12. Santagati S, Garnier M, Carlo P, Violani E, Picotti GB, Maggi A. Quantitation of low abundance mRNAs in glial cells using different polymerase chain reaction (PCR)-based methods. Br Res Prot, 1997; 1 (3): 217-23
13. Auckenthaler R, Risch $M$. Do Multiplex PCR techniques displace classical cultures in microbiology? Ther Umsch, 2015; 72 (2): 77-85.

14. Karlen Y, McNair A, Perseguers S, Mazza C, Mermod N. Statistical significance of quantitative PCR. BMC Bioinformatics, 2007; 8: 131.

15. Hudecova I. Digital PCR analysis of circulating nucleic acids. Clin Biochem, 2015; 142 (15): 9.

16. Sykes PJ, Neoh SH, Brisco MJ, Hughes E, Condon J, Morley AA. Quantitation of targets for PCR by use of limiting dilution. Biotechniques, 1992; 13: 444-9.

17. Kim TG, Jeong SY, Cho KS. Comparison of droplet digital PCR and quantitative real-time PCR for examining population dynamics of bacteriain soil. Appl Microbiol Biotechnol, 2014; 98 (13): 6105-13.

18. Jahn $M$, Vorpahl C, Türkowsky D, Lindmeyer $M$, Bühler B, Harms $\mathrm{H}$, et al. Accurate determination of plasmid copy number of flow sorted cells using droplet digital PCR. Anal Chem, 2014; 86 (12): 5969-76.

19. Wiencke JK, Bracci PM, Hsuang G, Zheng S, Hansen $\mathrm{H}$, Wrensch MR, et al. A comparison of DNA methylation specific droplet digital PCR (ddPCR) and real time GPCR with flow cytometry in characterizing human T cells in peripheral blood Epigenetics, 2014; 9 (10): 1360-5.

20. Hindson BJ, Ness KD, Masquelier DA, Belgrader P, Heredia NJ, Makarewicz AJ, et al. Highthroughput droplet digital PCR system for absolute quantitation of DNA copy number. Anal Chem, 2011; 83: 8604-10.

21. Sze MA, Abbasi M, Hogg JC, Sin DD. A comparison between droplet digital and quantitative PCR in the analysis of bacterial $16 \mathrm{~S}$ load in lung tissuesamples from control and COPD GOLD 2. PLoS One, 2014; 9(10): e110351.

22. Bhat $\mathrm{S}$, Herrmann J, Armishaw $\mathrm{P}$, Corbisier $\mathrm{P}$, Emslie KR. Single molecule detection in nanofluidic digital array enables accurate measurement of DNA copy number. Anal Bioanal Chem, 2009; 394: 457-67.

23. Vogelstein B, Kinzler KW. Digital PCR. Proc Natl Acad Sci USA, 1999; 96: 9236-41. 
24. Zhou W, Galizia G, Lieto E, Goodman SN, Romans KE, Kinzler KW, et al. Counting alleles reveals a connection between chromosome $18 \mathrm{q}$ loss and vascular invasion. Nat Biotechnol, 2001; 19: 78-81.

25. Pinheiro LB, Coleman VA, Hindson CM, Herrmann J, Hindson BJ, Bhat S, et al. Evaluation of a droplet digital polymerase chain reaction format for DNA copy number quantification. Anal Chem, 2012; 84: 1003-11.

26. White RA, Blainey PC, Fan HC, Quake SR. Digital PCR provides sensitive and absolute calibration for high throughput sequencing. BMC Genomics, 2009; 10: 116.

27. Takahashi K, Yan IK, Kim C, Kim J, Patel T. Analysis of extracellular RNA by digital PCR. Front Oncol, 2014; 4: 129.

28. Usmani-Brown S, Lebastchi J, Steck AK, Beam C, Herold KC, Ledizet M. Analysis of B-cell death in type 1 diabetes by droplet digital PCR. Endocrinology, 2014; 155 (9): 3694-8.

29. White TB, McCoy AM, Streva VA, Fenrich J, Deininger PL. A droplet digital PCR detection method for rare L1 insertions in tumors. Mob DNA, 2014; 5 (1): 30.

30. Dingle TC, Sedlak RH, Cook L, Jerome KR. Tolerance of droplet-digital PCR vs real-time quantitative PCR to inhibitory substances. Clin Chem, 2013;59: 1670-2.

31. Whale AS, Cowen S, Foy CA, Huggett JF. Methods for applying accurate digital PCR analysis on low copy DNA samples. PLoS One, 2013; 8: e58177.

32. Weisenberger DJ, Trinh BN, Campan M, Sharma S, Long TI, Ananthnarayan S, et al. DNA methylation analysis by digital bisulfite genomic sequencing and digital MethyLight. Nucleic Acids Res, 2008; 36: 4689-98.

33. Pekin D, Skhiri Y, Baret JC, Le Corre D, Mazutis $L$, Salem CB, et al. Quantitative and sensitive detection of rare mutations using droplet-based microfluidics. Lab Chip, 2011; 11 (13): 2156-66.

34. Chen WW, Balaj L, Liau LM, Samuels ML, Kotsopoulos SK, Maguire CA, et al. BEAMing and Droplet Digital PCR Analysis of Mutant IDH1 mRNA in Glioma Patient Serum and Cerebrospinal Fluid Extracellular Vesicles. Mol Ther Nucleic Acids, 2013; 2: e109.
35. White RA, Quake SR, Curr K. Digital PCR provides absolute quantitation of viral load for an occult RNA virus. J Virol Methods, 2012; 179 (1): 45-50.

36. Whale AS, Huggett JF, Cowen S, Speirs V, Shaw $\mathrm{J}$, Ellison $\mathrm{S}$, et al. Comparison of microfluidic digital PCR and conventional quantitative PCR for measuring copy number variation. Nucleic Acids Res, 2012; 40: e82.

37. Didelot A, Kotsopoulos SK, Lupo A, Pekin D, Li X, Atochin I, et al. Multiplex picoliter-droplet digital PCR for quantitative assessment of DNA integrity in clinical samples. Clin Chem, 2013; 59 (5): 815-23.

38. Dobnik D, Spilsberg B, Bogožalec Košir A, HolstJensen A, Žel J. Multiplex quantification of 12 European Union authorized genetically modified maize lines with droplet digital polymerase chain reaction. Anal Chem, 2015; 87 (16): 8218-26.

39. Spurgeon SL, Jones RC, Ramakrishnan R. High throughput gene expression measurement with real time PCR in a microfluidic dynamic array. PLOS One, 2008; 3: e1662.

40. Dressman D, Yan H, Traverso G, Kinzler KW, Vogelstein B. Transforming single DNA molecules into fluorescent magnetic particles for detection and enumeration of genetic variations. Proc Natl Acad Sci USA, 2003; 100: 8817-22.

41. Heyries KA, Tropini C, Vaninsberghe M, Doolin C, Petriv OI, Singhal A, et al. Megapixel digital PCR. Nat Methods, 2011; 8: 649-51.

42. Li M, Chen WD, Papadopoulos N, Goodman SN, Bjerregaard NC, Laurberg S, et al. Sensitive digital quantification of DNA methylation in clinical samples. Nat Biotechnol, 2009; 27: 858-63.

43. Weisenberger DJ, Trinh BN, Campan M, Sharma S, Long TI, Ananthnarayan S, et al. DNA methylation analysis by digital bisulfite genomic sequencing and digital MethyLight. Nucleic Acids Res, 2008; 36: 4689-98.

44. Nadauld L, Regan J, Miotke L, Pai RK, Longacre TA, Kwok SS et al. Quantitative and Sensitive Detection of Cancer Genome Amplifications from Formalin Fixed Paraffin Embedded Tumors with Droplet Digital PCR. Transl Med (Sunnyvale), 2012; 2(2): . 
45. Huggett JF, Foy CA, Benes V, Emslie K, Garson JA, Haynes R, et al. The digital MIQE guidelines: Minimum Information for Publication of Quantitative Digital PCR Experiments. Clin Chem, 2013; 59 (6): 892-902.

46. Manoj P. Droplet digital PCR technology promises new applications and research areas. Mitochondrial DNA, 2016; 27 (1): 742-6.
47. Baker M. Digital $P C R$ hits its stride. Nature Methods, 2012; 9(6): 541.

48. Pavšič J, Žel J, Milavec M. Assessment of the realtime PCR and different digital PCR platforms for DNA quantification. Anal Bioanal Chem, 2016; 408 (1): 107-21. 
TELIF HAKKI DEVRI / COPYRIGHT RELEASE

TÜRKIYE HALK SAĞLIĞI KURUMU/PUBLIC HEALTH INSTITUTION OF TURKEY

Türk Hijyen ve Deneysel Biyoloji Dergisi / Turkish Bulletin of Hygiene and Experimental Biology

.........../20...

Makale Türü/Article Type:

(...) Araştırma/Research (...) Derleme/Review (...) Olgu Sunumu/Case Report (...) Editöre Mektup/Letter to Editor

Makale Başlı̆̆ı/Article Entitled :

Sayın Editör,

Yayınlanması dileğiyle Türk Hijyen ve Deneysel Biyoloji Dergisíne gönderdiğimiz makalenin yazarları olarak;

1. Derginizde yayımlanmak üzere yollamış olduğumuz makalenin orjinal olduğunu; bilimsel ve etik sorumluluğunun bize ait olduğunu,

2. Makalenin; derginizdeki değerlendirme sürecinde başka bir yayın organına yayımlanmak üzere gönderilmediğini ve gönderilmeyeceğini,

3. Makalenin; kişilik ve telif haklarına aykırı kanun dışı maddeler içermediğini,

4. Yayın haklarının Türk Hijyen ve Deneysel Biyoloji Dergisi’ne ait olduğunu kabul ve beyan ederiz.

Dear Editor,

Here, we affirm and warranty as the author(s) of this manuscript submitted to Turkish Bulletin of Hygiene and

Experimental Biology that;

1. The article I / We submitted to the Bulletin is original and responsibilities are belong to us ethically and scientifically,

2. The article is not currently being considered for publication by any other journal and will not be submitted for such review while under the evaluation of this bulletin,

3. The article contains no unlawful statements and does not contain any materials that violate any personal or proprietary rights,

4. The article publishing rights belong to Turkish Bulletin of Hygiene and Experimental Biology.

(...)1) . .

İmza/Signature :

Yazışma Adresi/Corresponding Address :.

Tel/Phone :

..Faks/Fax

e-posta/e-mail :

(...)2) . .

İmza/Signature :

Yazışma Adresi/Corresponding Address

Tel/Phone :

..............

e-posta/e-mail :

(...)3) İmza/Signature :

Yazışma Adresi/Corresponding Address

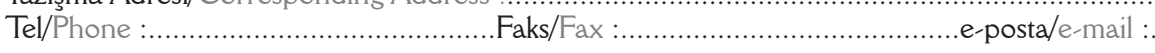

(...)4) İmza/Signature :

Yazışma Adresi/Corresponding Address

Tel/Phone :

Faks/Fax

e-posta/e-mail :

(...)5)

İmza/Signature :

Yazışma Adresi/Corresponding Address

Tel/Phone :.....

Faks/Fax :

e-posta/e-mail :

Not / Note : 1. İletişim kurulacak yazarın yanına $(X)$ işareti koyunuz / Please indicate the corresponding author with $(X)$

2. Formu aşağıdaki adrese faks/posta yolu ile gönderiniz veya elden teslim ediniz / Please send this form to the address below by faks or mail or deliver personally.

TÜRKIYE HALK SAĞLIĞI KURUMU / PUBLIC HEALTH INSTITUTION OF TURKEY

Türk Hijyen ve Deneysel Biyoloji Dergisi / Turkish Bulletin of Hygiene and Experimental Biology

Sağlık Mah. Adnan Saygun Cad. No: 55 Refik Saydam Yerleşkesi 06100 Sihhiye-ANKARA-TURKEY

Tel/Phone : +903125655579Ｆaks/Fax : +903125655591_e-posta/e-mail : turkhijyen@thsk.gov.tr 

